\title{
Družbeni in politični procesi v sodobnih slovanskih kulturah, jezikih in literaturah
}

Uredili

Alenka Čuš

Marcello Potocco Lidija Rezoničnik

Nina Zavašnik 
Uredniški odbor Založbe Univerze na Primorskem

Gregor Pobežin, UP Fakulteta za humanistične študije

Maja Meško, UP Fakulteta za management

Vito Vitrih, UP FAMNIT in UP IAM

Silva Bratož, UP Pedagoška fakulteta

Aleksandra Brezovec, UP FTŠ - Turistica

Ana Petelin, UP Fakulteta za vede o zdravstvu

Janko Gravner, University of California, Davis

Krstivoje Špijunović, Učiteljski fakultet Užice

Miloš Zelenka, Jihočeská univerzita $v$ Českých Budějovicích in Univerzita Konštantína Filozofa $v$ Nitre Jonatan Vinkler, Založba Univerze na Primorskem Alen Ježovnik, Založba Univerze na Primorskem 
družbeni in politični procesi v sodobnih slovanskih kulturah, jezikih in literaturah 



\section{Družbeni in politični procesi v sodobnih slovanskih kulturah, jezikih in literaturah}

Uredili Alenka Čuš, Marcello Potocco, Lidija Rezoničnik in Nina Zavašnik 


\section{Znanstvena monografija}

Družbeni in politični procesi $v$ sodobnih slovanskih kulturah, jezikih in literaturah

Uredili - Alenka Čuš, Marcello Potocco, Lidija Rezoničnik in Nina Zavašnik

Recenzenti - Tatjana Balažic Bulc (Oddelek za slavistiko, Filozofska fakulteta Univerza v Ljubljani),

Ljudmil Dimitrov (Katedra za rusko književnost, Fakulteta slovanskih filologij, Univerza v Sofiji in Oddelek za slavistiko, Filozofska fakulteta Univerza v Ljubljani), Lidija Dimkovska (Koper), Nikolaj Jež (Oddelek za slavistiko, Filozofska fakulteta Univerza v Ljubljani), Irina Makarova Tominec (Oddelek za slovenistiko, Fakulteta za humanistične študije, Univerza na Primorskem), Vladimir Osolnik (Oddelek za slavistiko, Filozofska fakulteta Univerza v Ljubljani), Katarina Podbevšek (Akademija za gledališče, radio, film in televizijo, Univerza v Ljubljani), Marcello Potocco (Oddelek za slovenistiko, Fakulteta za humanistične študije, Univerza na Primorskem), Barbara Pregelj (Oddelek za slovenistiko, Fakulteta za humanistiko, Univerza v Novi Gorici), Jonatan Vinkler (Oddelek za slovenistiko, Fakulteta za humanistične študije, Univerza na Primorskem)

Jezikovni pregled (angleški jezik) - Tony Muc in Alenka Čuš

Oblikovanje, prelom in priprava na izdajo * Saša Marsetti

Izdala in založila

Založba Univerze na Primorskem (zanjo: prof. dr. Dragan Marušič, rektor)

Titov trg 4, SI-60oo Koper

Glavni urednik - Jonatan Vinkler

Vodja založbe - Alen Ježovnik

Koper 2018

ISBN 978-961-7023-93-o (pdf)

http://www.hippocampus.si/ISBN/978-961-7023-93-o.pdf

ISBN 978-961-7023-94-7 (html)

http://www.hippocampus.si/ISBN/978-961-7023-94-7/index.html

DOI: https://doi.org/10.26493/978-961-7023-93-o

(C) 2018 Zveza društev Slavistično društvo Slovenije (Študentska sekcija)

Kataložni zapis o publikaciji (CIP) pripravili v Narodni in univerzitetni knjižnici v Ljubljani

COBISS.SI-ID $=294928128$

ISBN 978-961-7023-93-o (pdf)

ISBN 978-961-7023-94-7 (html) 


\section{Vsebina}

Nina Zavašnik

7 Uvodna beseda

\section{Razprave}

Alenka Čuš

11 Model za preučevanje izseljenskih skupnosti

na kanadsko-slovenskem primeru

Barbara Kopač

27 Primerjava jezikovnopolitičnega okvira in jezikovnih pravic narodnih skupnosti v Republiki Sloveniji in Kraljevini Švedski: študija primera na podlagi pregledane zakonodaje

Maja Smotlak

41 Med vključevanjem in izključevanjem - vprašanje identitete v sodobnem slovenskem romanu v Italiji (1991-2016)

Rok Andres

53 Gledališče na stičišču kultur: Slovensko stalno gledališče v Trstu v času po drugi svetovni vojni - uprizoritve, razmerja, položaj in usoda

Megi Rožič

67 Izkušnja migracije in integracije v slovenski prostor v avtobiografskih literarnih delih Stanislave Chrobakove Repar in Erice Johnson Debeljak

Mateja Eniko

83 Pesniška samorefleksija v poeziji Primoža Čučnika 
Jernej Kusterle

101 Slovenska ulična poezija po letu 1991 in vpliv nestrpnosti

Iveta Bůžková

119 Recepcija del Draga Jančarja na Češkem

Weronika Woźnicka

127 Nostalgia za komunizmem w polskiej wersji

Janja Vollmaier Lubej

139 Ukrajinske družbene spremembe v romanu Dvanajst krogov Jurija Andruhoviča

Константина Пунева / Konstantina Puneva

153 Романите на Толстой и киното Руски и неруски рефлексии

Tomislav Augustinčić

163 „Konačno demistificirati Goranovo djelo“:

društveno sjećanje na Ivana Gorana Kovačića

Mirela Ivanić, Jelena Perišić

177 Derivacija glagola sa osnovama stranog porekla u srpskom jeziku u svetlu (ne)jasne diferencijacije između srpskog

i hrvatskog standarda ${ }^{1}$

191 Avtorji / Authors 


\section{Uvodna beseda}

\section{Nina Zavašnik}

V pričujoči publikaciji so predstavljeni pisni prispevki na temo družbeni in politični procesi v slovanskih kulturah, jezikih in literaturah. Povod zanjo so dvojezičnost, presečišče kultur in s političnimi procesi pogojene družbene spremembe slovenskega obmejnega območja, družbene in politične posledice dogajanj ob razpadu nekdanje skupne države kot tudi priključitev slovanskih držav Evropski skupnosti leta 2004 (Slovenija, Češka, Poljska in Slovaška), 2007 (Bolgarija) in 2013 (Hrvaška). Poleg člankov na predpisano temo publikacija vsebuje tudi prispevke z interdisciplinarnimi temami, povezanimi s slavistiko in slovenistiko.

Publikacija (doktorskim) študentom oz. mladim doktorjem slavistike in slovenistike omogoča objavo njihovih najnovejših rezultatov in spoznanj. V njej svoje prispevke predstavlja 17 kandidatov iz Bolgarije, s Češke, Hrvaške, Poljske, iz Srbije in Slovenije. Poleg slovenščine so prispevki napisani še $\mathrm{v}$ bolgarščini, hrvaščini, poljščini in srbščini. Uredništvo vam ob branju publikacije želi obilo užitkov in novih, zanimivih informacij. 

Razprave 



\title{
Model za preučevanje izseljenskih skupnosti na kanadsko-slovenskem primeru
}

\author{
Alenka Čuš \\ Fakulteta za humanistične študije, Oddelek za slovenistiko, Univerza na Primorskem \\ Faculty of Humanities, Department for Slovene Studies, University of Primorska \\ alenkacus@gmail.com
}

V prispevku vzpostavljamo model za preučevanje izseljenskih skupnosti kot samostojne strukture na kanadsko-slovenskem primeru. $\mathrm{Z}$ dvoletnim terenskim delom in notranjim statusom raziskovanja smo skupnost opazovali po taksonomiji spremenljivk Howarda Gilesa (1977), ki določajo empirično realnost manjšinske skupnosti. Zaradi pomanjkljivosti tovrstnega pristopa $\mathrm{v}$ analizi smo se lotili vzpostavitve primernejšega modela s pomočjo literarnih študij, ki ne omogoča le opazovanja in ocene stanja skupnosti, temveč tudi na osnovi teorije udejanjanja narodnega poziva po Marcellu Potoccu (2012) dvig vitalnosti oz. krepitev slovenske narodne identitete. Model namreč omogoča aktivno udeležbo v okviru dejanj in implementacijo dodatnih dejanj, ki služijo opazovanju in urejanju le-teh glede na avtentične razmere in potrebe. Vitalnost skupnosti smo nato vnovič ocenili in primerjali s pilotsko oceno ter dokazali, da je pristop učinkovit.

Ključne besede: ocena vitalnosti, udejanjanje narodnega poziva, krepitev slovenske narodne identitete, kanadsko-slovenska izseljenska skupnost 


\section{A Research Model for Examining Diaspora Communities Applied to the Slovene-Canadian Case}

This paper presents a model for studying diaspora communities as independent structures for the Slovene-Canadian case. Using the researcher's two years of fieldwork as well as the intracommunity status of the researcher, we observed the community with the taxonomy of variables by Howard Giles (1977) that determines the empirical reality of minority communities. Due to the shortcomings of this approach in the analysis, we established a more appropriate model with the assistance of literary studies, which not only enables the monitoring and assessment of the community, but on the basis of the theory of realization of national interpellation by Marcello Potocco (2012), we are able to increase the actual vitality and strengthen the Slovene national identity. The model allows participation in the activity, not only for observing, but for implementation of additional activity as well according to the existing situations and needs of the community. The vitality of the community was re-assessed and the results compared with the pilot assessment. The comparison demonstrated that the proposed approach is effective.

Key words: vitality assessment, realization of the national interpellation, empowerment of the Slovene national identity, Slovene-Canadian diaspora community

Skupnost kanadskih Slovencev temelji na prostovoljnem delu in ohranjanju slovenske narodne identitete v kulturni komponenti. V provinci Ontario obstaja več kot 30 kanadsko-slovenskih institucij, ki so med seboj povezane s krovno organizacijo Vseslovenski kulturni Odbor/All Slovenian Cultural Committee (pogovorno VSKO) v Torontu. V južnem Ontariu za to skrbi SKON Niagara, ki je prav tako vključena v VSKO, ter slovenski župniji v Torontu (Brezmadežne s čudodelno svetinjo) in Hamiltonu (sv. Gregorija Velikega). Urška Strle (2009, 4-6) ugotavlja, da je v Sloveniji poudarek na raziskovanju Slovencev v Avstraliji in Argentini ter drastični primanjkljaj podatkov na temo kanadskih Slovencev, ki so jih v preteklosti, ne glede na povsem drugačno ozadje ciljne kulture Kanade, večinoma obravnavali kar skupaj s Slovenci v ZDA. Za osrednji predmet preučevanja si torej določimo makrosociolingvistično (institucionalno in kolektivno) delovanje ontarijskih Slovencev, in sicer za obdobje 2014-2015. Ne zanima nas le, na kakšen 
način se v skupnosti ohranja slovenska narodna identiteta, ampak predvsem sodobno stanje skupnosti ter možnosti za njeno krepitev.

Obravnave skupnosti se lotimo $\mathrm{z}$ aplikativnim pristopom ${ }^{\mathrm{I}}$ oziroma $\mathrm{z}$ metodo pragmatizma, katere jedro je po Williamu Jamesu sledenje praktičnim posledicam $(2002,214)$. Pragmatična metoda torej izvira iz sledenja strukturi realnosti in strukturi našega spoznavanja le-te $(2002,220)$, pri čemer je realnost odprta, ranljiva, nedokončana, subjekt pa nastopi, da jo konča (Šimenc 2002, 223). James pragmatizem vidi kot pogled v prihodnost, v primerjavi z racionalizmom, ki se ozira k pretekli večnosti (2002, 123). Potemtakem pragmatizem omogoča empirični pristop, ki se »obrne k stvarnosti in skladnosti, dejstvom, delovanju in moči« (James 2002, 39). Postavke za sledenje strukturi realnosti smo določili po modelu Howarda Gilesa (Nećak Lük 1998) oziroma njegovi t. i. taksonomiji strukturnih spremenljivk, ki učinkujejo na etnično-jezikovno vitalnost skupnosti in naj bi torej predstavljale neposredno empirično realnost manjšinske skupnosti. Delijo se na: statusne spremenljivke, ki kažejo izoblikovanost prestižnih skupnostnih statusov (pravni; politični; ekonomski; socialni; družbeno-zgodovinski; jezikovni); demografske spremenljivke, ki prikazujejo skupnost $\mathrm{v}$ številkah (nacionalni teritorij; koncentracija razmerja; absolutno število; naravni prirastek; mešani zakoni; imigracije; emigracije) ter institucionalno podporo (državna in/ali lastna institucionalna podpora $\mathrm{v}$ organizaciji manjšine; množična občila; vzgoja in izobraževanje; administrativne usluge; industrija; veroizpoved; kultura; stiki z matico). Giles poleg analize teh okoliščin empirične realnosti upošteva še subjektivni vidik pripadnikov. Preverja samopercepcijo manjšine v imenu članov skupnosti ter zunanjih opazovalcev oz. večine, obojih z vprašalnikom (Nećak Lük 1998, 25). Slednji Gilesov pristop za subjektivno oceno vitalnosti nadomestimo $s$ t. i. participativnim modelom, kar po Michaelu Mullerju pomeni pristop in dizajniranje $\mathrm{z}$ namenom, da se $\mathrm{v}$ procesu načrtovanja skuša aktivno vključiti vse strani sodelujočih. Tako se zagotovi, da rezultati ustrezajo potrebam skupnosti in da so zaradi tega sploh uporabni (Participatory Design 2015). Za ta model se odločimo, ker želimo, da rešitve za krepitev slovenske narodne identitete $\mathrm{v}$ prvi vrsti ustrezajo obstoječim avtentičnim razmeram ter potrebam kanadsko-slovenske skupnosti in ne perspektivi ter pravnoformalnim aktom matične Slovenije, vezanih na Slovence v izseljenstvu.

23 tednov terenskega dela med kanadskimi Slovenci v Ontariu od skupno 110 je delno financiral Javni sklad RS za razvoj kadrov in štipendije za študijski obisk Vloga literature $v$ konstrukciji naroda $\mathrm{v} 2014$. 
V letu 2013 smo začeli s pilotskim ocenjevanjem vitalnosti skupnosti. V seštevku skupne ocene vitalnosti po posamičnih kategorijah smo statusne spremenljivke kanadsko-slovenske skupnosti ocenili z oceno srednja vitalnost, institucionalno podporo z oceno srednje nizko. Zaradi pomanjkanja podatkov demografskih spremenljivk pa teh niti ni bilo mogoče oceniti (Čuš 2013), zato ugotavljamo, da po Gilesovem modelu ne moremo pripraviti ocene vitalnosti skupnosti $\mathrm{v}$ celoti. Šele $\mathrm{z}$ notranjim statusom raziskovanja smo ugotovili tudi druge pomanjkljivosti Gilesovega modela. Ta je namreč popolnoma osredotočen na formalno delovanje skupnosti, kar nas postavi v veliko zadrego pri iskanju zapisanih argumentov, ko zaradi prostovoljnega dela delovni procesi večinoma potekajo neformalno in/ali v govorjenem jeziku. Prav tako smo prišli do sklepa, da čeprav gre za model, ki je namenjen ocenjevanju vitalnosti manjšin, preveč zavzema stališča perspektive večinskega naroda oz. matične domovine. To je razvidno že iz same zastavljene postavke državna in/ali lastna institucionalna podpora $\mathrm{v}$ organizaciji manjšine. Ravno zaradi perspektive izvorne države Gilesovega modela ne moremo uporabiti za ustrezno analizo vitalnosti strukture realnosti, saj skupnost opazujemo kot samostojno in ne priključeno strukturo. To pomeni, da jo opazujemo od znotraj ter s stališča kanadsko-slovenske skupnosti in ne s perspektive izvorne ali ciljne države. Tak pristop se izkaže za zelo relevantnega, zato izbira Gilesovega modela ne zadostuje oz. ne ustreza.

Vzporednice za ohranjanje in krepitev narodne identitete iz sociolingvistike smo ugotovili v literarni zgodovini, v delu Marcella Potocca, Nacionalni imaginariji, literarni imaginariji: različice narodnega poziva $v$ literaturi in literarnih kontekstih (2012) in v udejanjanju narodnega poziva (tudi interpelacije oz. naslavljanja). Narodni poziv po Potoccu združuje imaginarno in ideologijo. Imaginarno pomeni zmožnost tvorjenja podob ali neomejen tok podob, ki je razpoložljiv za zamejitve v simbolnih odnosih in so ga skupnosti vedno skušale fiksirati. Ideologijo pa Potocco razume kot udejanjanje družbeno imaginarnega, ki teži k fiksaciji pomena (2012, 238). Po Bogdanu Lešniku narodni poziv pomenijo dejanja v praksi, saj že Althusser vidi ideologijo kot družbeno tkivo in kot najrazličnejše rituale materialne eksistence ideološkega aparata, npr. mašo v cerkvi, nepomembno nogometno tekmo $\mathrm{v}$ športnem društvu, šolski dan v neki šoli (1997, 23-25). Lešnik kot dva pogoja za posrečeno interpelacijo navaja prepoznanje dejanja in opiranje na predhodno interpelacijo (Lešnik 1997, 39-40). Potocco se v izhodišču loti vprašanja naroda in ga opredeli kot 
imaginarno, diskurzivno ter ideološko konstrukcijo, zgrajeno s pomočjo šolstva in simbolnih figur; nato pa še utemeljevitvenega mita in literarnih, družbeno-historičnih ter socioloških vidikov slovenske in kanadske literarne zgodovine (2012, 241). Kot izvor družbene identitete sprva vpelje pojem imaginarnega po Corneliusu Castoriadisu, ga poveže z ideologijo in literaturo. Nato obravnava materialne dejavnike za narodni poziv oz. udejanjanje ideološke funkcije narodne interpelacije za strukturo večinskega naroda, in sicer družbenozgodovinski razvoj, institucije in medije, literarni sistem, založniški trg ter šolski sistem (Potocco 2012).

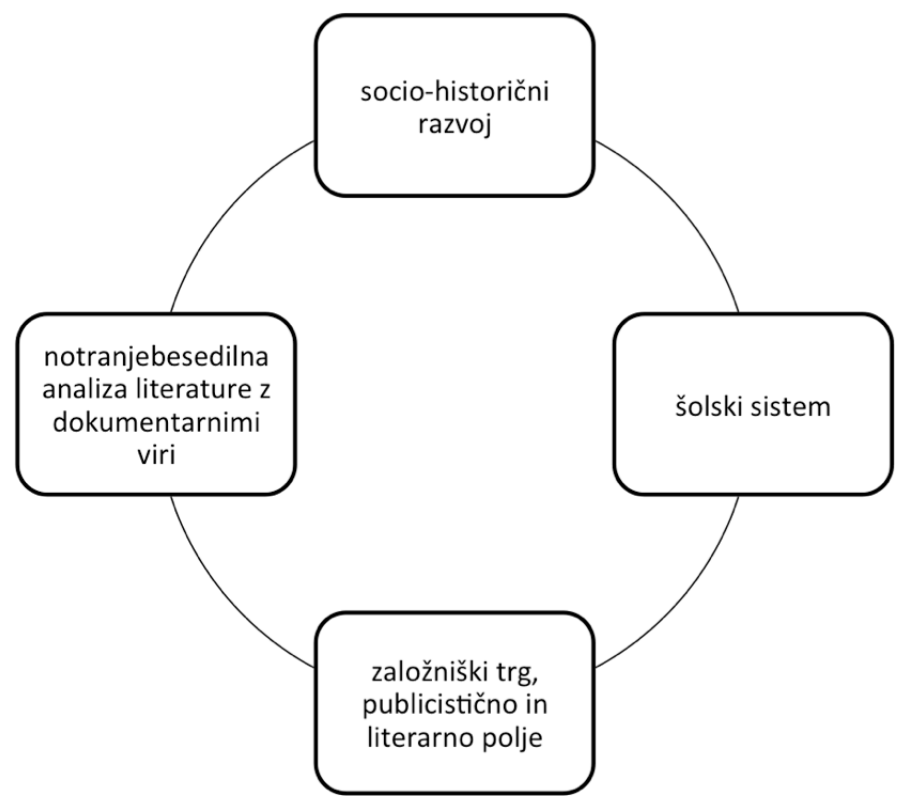

\section{Model I: Model materialnih dejavnikov udejanjanja narodnega poziva po Marcellu Potoccu (2012)}

Tovrstni dejavniki se že na prvi pogled skladajo s podobo, ki jo sicer nudi tudi že sociolingvistični pristop in Gilesov model. Ker pa se spremeni predmet preučevanja, torej, ker v ospredje stopi književnost, ravno tako pa tudi metode, se krepitev narodne identitete obravnava na drugačen način. Potemtakem ne gre samo za opazovanje in oceno vitalnosti empirične realnosti, pač pa za dejanja naslavljanja v praksi, kot pravi Lešnik. S tovrstnim pristopom ocenjujemo njeno vitalnost, poleg tega pa tudi opazujemo dejanja, krepimo obstoječa ali dodamo nova. Potoccove dejavnike si zato 
zastavimo kot področja raziskovalčevega delovanja v skupnosti; torej ne samo za opazovanje, kot bi bilo po Gilesovem modelu, ampak za področja aktivne participacije. Slednje nam omogoča tako spremljanje kot morebiti tudi apliciranje ustreznih smernic narodnega poziva za krepitev slovenske narodne identitete. Literarni pristop skratka temelji na imaginarnem in ideologiji, medtem ko sociolingvistični na empirični realnosti in instituciji. Gilesov model izseljensko skupnost opazuje s perspektive večinskega naroda oz. matične domovine, Potoccov pa znotraj in kot samostojno strukturo. Ker model po Potoccu ponuja rešitve za težave, na katere smo naleteli pri rabi Gilesovega modela, se izkaže za ustrezno rešitev v obravnavi ohranjanja ter krepitve narodne identitete, četudi gre v našem primeru za izseljensko skupnost in ne za enonacionalno večinsko strukturo $\mathrm{z}$ namenom državotvornosti, kot je to pri Potoccu. Za kanadski in slovenski primer Potocco ugotavlja, da sta izhajala iz splošne paradigme evropskega in neevropskega kulturnega nacionalizma $(2012,241)$, kar pomeni, da tip konstrukcije naroda ni utemeljen v politično-teritorialni ali državni enotnosti, ampak v principu skupnega etničnega in kulturnega izvora $(2012,37)$. Navedeno lahko velja tudi za izseljensko skupnost v sodobnem času, iz česar lahko sklepamo, da lahko njegovi dejavniki za udejanjanje narodnega poziva držijo tudi za izseljensko oz. manjšinsko skupnost.

Sčasoma se je izkazalo, da navedeno ne drži povsem in da moramo biti pri opazovanju dejavnikov v manjšinski skupnosti natančnejši. Poglavitni dejavniki so lahko v večji meri oslabljeni, narodni poziv pa se na primeru izseljenske skupnosti udejanja tudi na drugih področjih. Z empiričnim preverjanjem Potoccovega modela v sinhronem preučevanju smo potemtakem določili dejavnike, ki veljajo za udejanjanje narodnega poziva, specifično za izseljensko skupnost. $\mathrm{V}$ aplikativnem pristopu smo sodelovali v najrazličnejših dejavnostih skupnosti in ugotavljali, kje in kako se udejanja narodni poziv. Dejanja kanadsko-slovenskega primera smo torej analizirali tako predvsem na recepcijski strani na vseh področjih, na nekaterih pa tudi pri produkciji. Rezultati empiričnega pristopa se na prvi pogled ujemajo $\mathrm{z}$ ugotovitvami Potocca. Četudi gre v našem primeru za sinhrono preučevanje manjšinske skupnosti v sodobnem času, drži, da so najmočnejši dejavniki še vedno šolski sistem, literarna institucija ter družbeno-institucionalni kontekst (v diahronem preučevanju po Potoccu socio-historični razvoj). Kljub temu pa je specifično za izseljensko skupnost potrebno obrazložiti dejavnike po Potoccu ter določiti še druge, ki prav tako udejanjajo narodni poziv. Potocco za enega izmed dejavnikov določa šolski sistem, ki se je tudi 
Tabela i: Ohranjanje in krepitev narodne identitete

\begin{tabular}{|c|c|}
\hline \multicolumn{2}{|c|}{ OHRANJANJE IN KREPITEV NARODNE IDENTITETE } \\
\hline JEZIKOSLOVJE/SOCIOLINGVISTIKA & LITERARNA ZGODOVINA \\
\hline $\begin{array}{l}\text { OCENA ETNIČNO-JEZIKOVNE } \\
\text { VITALNOSTI } \\
\text { ocena vitalnosti - spremenljivke za determini- } \\
\text { ranje emp. realnosti }\end{array}$ & $\begin{array}{l}\text { UDEJANJANJE NARODNEGA POZIVA } \\
\text { ocena in dvig vitalnosti (dejanja/krepitev) }\end{array}$ \\
\hline $\begin{array}{l}\text { Taksonomija spremenljivk po Gilesovem } \\
\text { modelu, ki določajo emp. realnost: } \\
\text { - statusne (pravni, politični, ekonomski, } \\
\text { socialni, družbeno-zgodovinski, jezikovni } \\
\text { status) } \\
\text { - demografske (nacionalni teritorij, } \\
\text { koncentracija razmerja, absolutno število, } \\
\text { naravni prirastek, mešani zakoni, imigracije, } \\
\text { emigracije) } \\
\text { - institucionalna podpora (državna in/ali lastna } \\
\text { v organizaciji manjšine, množična občila, } \\
\text { vzgoja in izobraževanje, administrativne } \\
\text { usluge, industrija, religija, kultura, stiki z } \\
\text { matico) } \\
\text { (Nečak Luk 1998, 35) }\end{array}$ & $\begin{array}{l}\text { Materialni dejavniki udejanjanja narodnega po- } \\
\text { ziva v literaturi po Potoccu (2012): } \\
\text { - družbenozgodovinski razvoj; } \\
\text { - institucije in mediji } \\
\text { - založniški trg } \\
\text { - literarni sistem } \\
\text { - šolski sistem }\end{array}$ \\
\hline $\begin{array}{l}\text { + subjektivni vidik: } \\
\text { Mullerjeve postavke za participativni model: } \\
\text { identitete; delovni jezik; delovna dinamika } \\
\text { in predpozicije; razmerja in dogovori; ter } \\
\text { kolektivne akcije. } \\
\text { (Muller in Druin } 2003,12 \text { ) }\end{array}$ & \\
\hline
\end{tabular}

v izseljenski skupnosti izkazal za dejavnega in smo zato načrtno največ časa posvetili ravno šolstvu. Nadalje pa moramo dodati, da se narodni poziv na tem področju ne izraža zgolj in samo v šolstvu, torej v slovenski sobotni šoli in tečajih slovenščine kot drugega tujega jezika, pač pa tudi širše v skupnosti, v celotni sferi vzgoje in izobraževanja, saj se izvajajo in so močno zastopane še izobraževalne dejavnosti v zvezi s športom in glasbo. Pevski zbori, folklora in skavti so namreč tudi pojmovani kot institucije, ravno tako kot slovenska šola. Za primer manjšinske skupnosti potemtakem trdimo, da šele vse te institucije skupaj tvorijo izobraževalni sistem za udejanjanje narodnega poziva, in ne zgolj šolstvo. Namesto šolskega sistema kot dejavnika narodnega poziva zato določimo širše področje, vzgojo in izobraževanje. $\mathrm{V}$ določanju specifičnih dejavnikov za manjšinsko skupnost niti ne izpustimo Potoccove predpostavke za znotrajbesedilno analizo literature $\mathrm{z}$ dokumentarnimi viri, in njegove trditve, da se narodni poziv ne udejanja samo $\mathrm{z}$ literaturo kot produkti, ampak tudi vsebinsko. To je namreč zelo pomembno 
še posebej za izseljensko skupnost, saj so dokumentarni viri o kanadskih Slovencih in njihovi skupnosti pomanjkljivi, dostopni pa večinoma ravno $\mathrm{v}$ obliki umetnostnih besedil. Tako nam lahko notranjebesedilna analiza prinese veliko materiala oz. argumentov o izseljenskih okoliščinah, četudi služijo le za razumevanje socio-historičnega razvoja. Ravno zato jo predlagamo tudi v modelu dejavnikov narodnega poziva za izseljensko skupnost, a predstavlja le del celotnega dejavnika literarne institucije, saj se drugi dejavniki izkažejo kot enakovredno relevantni glede na obseg. Relevantna se zdi tudi raba jezika, saj ne obravnavamo večinskega naroda, ki ga na izvornem ozemlju povezuje en jezik. V izseljenski skupnosti se dejavniki narodnega poziva lahko udejanjajo $\mathrm{v}$ dveh jezikih, hkrati pa raba slovenščine in izbira le-te pred angleščino, ki je jezik okolja, postane sama po sebi močan materialni dejavnik. Jezik ravno tako opazujemo tudi v govorjeni in ne le zapisani obliki, kot bi obveljalo za diahrono preučevanje po Potoccovem modelu, prav tako pa tudi $\mathrm{v}$ neformalnem položaju, ne le formalnem. Izseljenska skupnost deluje $\mathrm{v}$ okviru skupnega preživljanja prostega časa njenih pripadnikov, ki je pojmovano kot njihova primarna dejavnost, ker je vezana predvsem na družinske navade, običaje in tradicije ter religiozno izročilo, in je recimo vidna $\mathrm{v}$ udeležbi kolektivnih zbiranj $\mathrm{v}$ obliki banketov s slovensko hrano in glasbo. Zato dodamo še samostojen dejavnik izven literarne institucije, ki velja specifično za izseljensko skupnost, da se intenzivno udejanja narodni poziv slovenske identitete. Sem smo uvrstili religijsko izročilo, glasbo, kulinariko, šport in gospodarstvo. Glede na kanadsko-slovenski primer v 2014 in 2015 torej določimo materialne dejavnike za udejanjanje narodnega poziva za izseljenske skupnosti v sodobnem času, in sicer: družbeno-institucionalni kontekst (socio-historični razvoj v sinhronem preučevanju); vzgoja in izobraževanje; literarna institucija - založniški trg, mediji, literarni sistem (zunaj- in znotrajbesedilna analiza); raba jezika (zapisanega/govorjenega) ter pod drugo religijsko izročilo, glasba, gospodarstvo, kulinarika, šport.

Skupnost torej krepi slovensko narodno identiteto po dolgoletnem ustaljenem prostovoljnem ritmu $\mathrm{z}$ organiziranjem kulturnih, glasbenih, športnih in cerkvenih prireditev ter aktivnosti. Te pa se z leti manjšajo na številčnosti tako produkcije kot tudi recepcije - manjša se število aktivnosti, ciljna publika oz. udejstvovanje pripadnikov, še najbolj pa se dejanja narodnega poziva obstoječih šibijo. $\mathrm{V}$ aplikativnem pristopu ravno zato nismo samo opazovali in določali dejavnikov narodnega poziva, pač pa avtentične razmere in potrebe tudi sproti analizirali. Zaradi notranjega statusa razisk- 


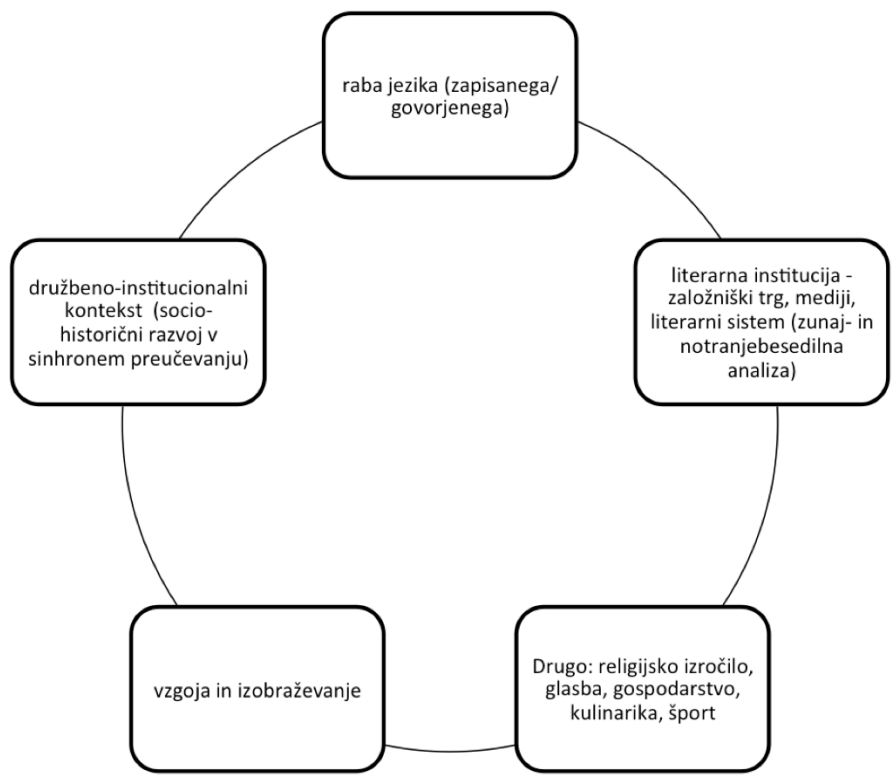

Model 2: Materialni dejavniki udejanjanja narodnega poziva v izseljenski skupnosti

ovanja pa smo sčasoma lahko še predlagali in uresničili dodatna dejanja $\mathrm{z}$ upoštevanjem participativnega modela. Najuspešnejši smo bili na področju tiskanega medija, Glasila, v 6. razredu Slovenske šole ter v spodbujanju govorjene rabe slovenskega jezika. Zagotovo pa smo vsaj z minimalnimi dejanji vplivali na vse dejavnike udejanjanja narodnega poziva. Če po obdobju terenskega dela v 2014 in 2015 znova ocenimo vitalnost skupnosti po Gilesovi taksonomiji spremenljivk zaradi natančnejšega uvida v obstoječa dejanja narodnega poziva, prav tako pa zaradi krepitve slovenske narodne identitete $\mathrm{v}$ dejavnikih predlaganega literarnega modela, dobimo takšno oceno:

Glede na to, da se v 2014 in 2015 niso spreminjali niti pravno-formalni akti, vezani na Slovence po svetu v Sloveniji, niti migracijska politika, vezana na obstoječe priseljenske skupnosti v Kanadi, ali akti skupnosti kanadsko-slovenske skupnosti, je ocena za pravni status ostala nespremenjena oz. taka, kot smo jo ocenili v pilotski oceni, ko smo posebno pozornost namenjali ravno zakonodaji (Čuš 2013). Oceno političnega statusa pa smo ocenili s kar dvema ocenama višje. Po spomladanskih volitvah 2015 v krovni VSKO, ko je po več letih predsedovanja Marjana Kolariča 
Tabela 2: Ocena vitalnosti kanadsko-slovenske skupnosti v Ontariu za 20I4-20I5

\begin{tabular}{lll}
\multicolumn{1}{c}{ Statusne spremenljivke } & Demografske spremenljivke & \multicolumn{1}{c}{ Institucionalna podpora } \\
\hline $\begin{array}{l}\text { Pravni status } \\
\text { S S }\end{array}$ & $\begin{array}{l}\text { Skupnostni teritorij } \\
\text { SV SV }\end{array}$ & $\begin{array}{l}\text { Lastna v organizaciji manjšine } \\
\text { S SV }\end{array}$ \\
\hline $\begin{array}{l}\text { Politični status } \\
\text { SN SV }\end{array}$ & Koncentracija razmerja & $\begin{array}{l}\text { Množična občila } \\
\text { SN SV }\end{array}$ \\
\hline Ekonomski status & $/$ & Vzgoja in izobraževanje SN SV \\
S SV & Absolutno število & \\
\hline Socialni status & $/$ & Administrativne usluge SN SN \\
S & Naravni prirastek & Industrija \\
\hline $\begin{array}{l}\text { Družbeno zgodovinski status } \\
\text { S S }\end{array}$ & Mešani zakoni & N S \\
\hline Jezikovni status: & $/$ & Religija \\
znotraj skupnosti N S & Imigracije, emigracije & S S \\
zunaj skupnosti N N & $/$ & Kultura \\
\hline & & S S \\
\hline S S-SV & & Stiki z matico \\
& & S SV \\
\hline
\end{tabular}

Legenda: $\mathrm{N}$ = nizka, $\mathrm{SN}=$ srednje nizka, $\mathrm{S}=$ srednja, $\mathrm{SV}=$ srednje visoka, $\mathrm{V}=$ visoka vitalnost

Pilotska ocena $=$ prva postavka; ocena vitalnosti $=$ druga postavka

zamenjal Milan Vinčec, je namreč skupnost tako pridobila dodatnega političnega predstavnika. Marjan Kolarič je namreč še vedno tudi predstavnik kanadskih Slovencev v Svetu Vlade RS za Slovence po svetu, pred tem pa je obe funkciji opravljal sam. Najverjetneje zaradi nove podpredsednice VSKO, Magdalene Symrajh Razpotnik, ki je bila dosedanja leta predsednica SKON Niagara, južnoontarijske krovne organizacije, je toronški VSKO v 2015 po več letih organiziral dobrodelno kosilo za podporo radia Glas in Glasila v Hamiltonu, s čimer je okrepil odnose z južnim Ontariem (Kačičnik 2016a). Podobno smo tako v letu 2014 kot tudi 2015 krovni VSKO vnovič povezali z vsemi slovenskimi organizacijami po Ontariu tudi preko njemu lastnega tiskanega medija, Glasila, ko smo po participativnem modelu iz maloštevilnega uredništva krog dopisnikov razširili na kar 40 dopisnikov za prispevke in fotografije. Ker tovrstna poročanja iz posameznih organizacij običajno pripravljajo predsedniki ali odborniki, lahko ta dejanja narodnega poziva na področju medijev ter drugih političnih premikov zagotovo pripišemo k povišanju ocene za politični status. Pomembno za 
politični status kanadsko-slovenske skupnosti pa je še dejstvo, da je Kanada v letu 2014 po nekaj letih spet dobila slovenskega veleposlanika, Marjana Cencena (Čuš 2014), do takrat pa je to funkcijo opravljala Irena Gril kot pooblaščena ministrica. Prav tako se je povišala ocena ekonomskemu statusu. S 1. januarjem 2016 sta se namreč združili obe slovenski banki v eno, za kar so dogovarjanja in postopki zagotovo tekli že v preučevanem obdobju 2014-2015. Poleg tega je jeseni 2014 v Kanadsko-slovenski gospodarski zbornici nastopil novo izvoljeni odbor s prenovljenim programom, ki po novem spet skrbi za številna srečanja in izobraževalne seminarje slovenskih gospodarstvenikov v Kanadi. Zato smo povišali oceno tudi industriji, ker smo ugotovili, da se slovenska narodna identiteta udejanja tudi z institucionalnim povezovanjem slovenskih podjetij. Jezikovni status znotraj skupnosti v 2014 in 2015 se je prav tako dvignil vsaj za oceno. S svojimi aktivnostmi smo v skupnosti tako $\mathrm{v}$ institucionalnem delovanju kot tudi s pripadniki na terenu izven nje komunicirali v slovenščini, če je bilo to le mogoče glede na predispozicije sogovornikov, in smo jih spodbujali $\mathrm{k}$ rabi slovenskega jezika. Tako tudi v formalnem položaju, ko smo na primer na letnem srečanju predsednikov društev, včlanjenih v VSKO, kljub celotnemu poteku sestanka $\mathrm{v}$ angleškem jeziku poročali o preteklem letu ter načrtih za prihodnje leto za Glasilo v slovenščini. Prav tako smo v Glasilu v letu 2015 uvedli rubriko z nalogami za utrjevanje slovenščine ter držali enakovredno razmerje prispevkov med slovenščino in angleščino. Rabo slovenščine smo spodbujali v interakciji $z$ najrazličnejšimi pripadniki skupnosti na prireditvah in banketih, prav tako pa dvakrat tedensko s številnimi pripadniki v slovenski prodajalni. Ker smo v dejavniku narodnega poziva k rabi slovenščine imeli možnosti za uveljavljanja dejanj za kar najširši obseg, lahko trdimo, da smo v obdobju 2014 in 2015 vitalnost skupnosti na področju rabe jezika zagotovo dvignili vsaj za oceno.

Za institucionalno podporo se je ocena zvišala za eno oceno na več področjih. Pri opazovanju institucionalne podpore $\mathrm{v}$ organizaciji manjšine v obdobju 2014-2015 smo slednjo postavko ocenili za eno višje, ker se je obstoječemu sistemu organizacij v 2015 pridružilo društvo Preskok. Ta je za vitalnost kanadsko-slovenske skupnosti izrednega pomena, saj gre za društvo izven obstoječih okvirjev politične in ekonomske emigracije kanadskih Slovencev. Združuje mlade Slovence, ki prihajajo v Kanado po letu 2008, s tem pa so vpeti v mrežo institucij skupnosti preko pobratenja z društvom Slovenski dom. Novodobni priseljenci se namreč po večini ne vključujejo $\mathrm{v}$ dejavnosti širše kanadsko-slovenske skupnosti oz. se v 
njih udejstvujejo le nekateri, pa še to na večjih letnih prireditvah, organizirajo pa lastna srečanja nekajkrat letno, običajno filmske večere $\mathrm{v}$ centru Toronta. Oceno za področje množičnih občil smo povišali za kar dve oceni zaradi poglobljenega uvida $\mathrm{v}$ terenske razmere, do česar pri pilotskem ocenjevanju še nismo imeli dostopa. Radio Glas kanadskih Slovencev po novem ocenjujemo kot močno in utrjeno institucijo ter medij, ki skrbi za redno udejanjanje narodnega poziva, tako $\mathrm{v}$ obliki glasbe in rabe slovenskega jezika kot tudi poročanja in vpetosti ustaljene uredniške in tehnične ekipe $\mathrm{v}$ skupnost po participativnem modelu, saj oddajo tvorijo tudi pripadniki s čestitkami, oglasi prireditev v skupnosti posameznih društev, urednici pa se tudi redno udejstvujeta vseh prireditev skupnosti. V pilotskem ocenjevanju in predhodnem obisku terena ravno tako še nismo zaznali t. i. newsletterjev, ki so zelo pomembna in aktivna ter zapisana medijska orodja, tako v preteklosti kot tudi v letih v 2014 in 2015. Gre za redne publicistične 4-stranske oblike internega značaja $\mathrm{v}$ angleškem jeziku $\mathrm{z}$ nekaterimi slovenskimi članki, na primer Our Story Kanadsko-slovenskega zgodovinskega društva in Newsletter Krekove banke, ki sta v elektronski obliki nekajkrat letno posredovana seznamu pripadnikov, ki so z njimi kakorkoli povezani. Ponekod se najdejo tudi tiskane verzije, npr. Krekov na lastnih bančnih okencih ter Our Story v obeh župnijah. Prav tako izdaja Novice še slovenski dom za ostarele Lipa. Tedenske tiskane novice izdajata tudi obe slovenski župniji, to sta Vestnik hamiltonske župnije (razposlan tudi elektronsko) in Župnijski list toronške, ki sta večinoma striktno dvojezična in vsebujeta poročila, novice, napovedi, nauke nedeljskih maš ter tudi oglaševanje. Vsebinsko-strukturne in tehnične izboljšave ter občutno povečanje uredništva pa je v tem obdobju zagotovo bilo deležno ravno Glasilo, osrednja publikacija Slovencev v Kanadi, zato oceno vitalnosti na področju množičnih občil za kanadsko-slovensko skupnost v Ontariu ocenjujemo z oceno srednje visoko. Na področju vzgoje in izobraževanja v 2014-2015 ni bilo bistvenih sprememb v institucionalnem delovanju skupnosti, še vedno redno delujejo pevske in folklorne skupine kot pri pilotni oceni, le da se je Slovenski šoli po več letih šolski urnik v šolskem letu 2014/2015 skrajšal za eno uro in da je decembra 2015 prvič v zgodovini slovenske župnije Brezmadežne odpadlo Miklavževanje, ki velja za osrednjo otroško-mladinsko prireditev leta $v$ skupnosti. Slovenska šola $v$ Torontu, ki jo obiskuje sto učencev letno, je v letu 2014 ustanovila Delovno skupino za kurikulum, tako Slovenska šola Toronto kot Slovenska šola Hamilton pa sta novembra 2014 v sodelovanju s Centrom za slovenščino kot drugim/tujim jezikom in 
Uradom Vlade RS za Slovencev v zamejstvu in po svetu organizirali seminar za poučevanje slovenščine kot drugega tujega jezika za izseljenske učiteljice v Kanadi. Tega so do sedaj izvajali le v Ljubljani, torej gre za dogodek enkratnega značaja. Zaradi produkcijsko in recepcijsko učinkovitega načrtovanja pouka jezika in književnosti $v$ dveh šolskih letih 6 . razreda $\mathrm{v}$ Torontu (20 učencev) in vzpostavitve medkulturnega modela učne priprave za pouk jezika in književnosti $\mathrm{z}$ udejanjanjem narodnega poziva za izseljensko prostovoljno šolo, specifično na toronškem primeru, ki bo po končani raziskavi Delovni skupini za kurikulum Slovenske šole Toronto predlagan $\mathrm{v}$ razmislek za univerzalni kurikulum, smo oceno vzgoje in izobraževanja ocenili z oceno višje.

V obdobju 2014-2015 ni bilo bistvenih sprememb na področju administrativnih uslug, industrije in religije, saj gre za področja, kjer se spremembe dogajajo le redko in izredno počasi. Še vedno deluje Informacijski center VSKO ob sobotah kot zadnja leta poprej, prav tako so povsem ustaljene administrativne usluge društev (obveščanje o dogodkih, prodaja vstopnic ipd.) ter cerkvene dejavnosti. Tako je tudi na področju kulture. Za oceno višje smo ocenili še stike $z$ matično domovino. Česar pri pilotski oceni še nismo upoštevali, je, da so stiki s Slovenijo zelo aktivni zaradi slovenskega Veleposlaništva v Ottawi, ki se kljub oddaljenosti od Toronta ( 5 ur severno) in društev v južnem Ontariu redno udejstvuje prireditev v skupnosti ter z njo sodeluje, kjer je to mogoče, tako v letu 2014 kot tudi 2015. Pomembno dejanje okrepljenih stikov $\mathrm{z}$ matično domovino je tudi po več letih obisk ministra za Slovence v zamejstvu in po svetu, Gorazda Žmavca, ki je obiskal skupnost tako v Ontariu kot tudi Vancouvru, Edmontonu, Calgaryju in Winnipegu (Kačičnik 2016b). Čeprav se je to zgodilo spomladi 2016, in ne v preučevanem obdobju 2014-2015, pa se je tega že takrat načrtovalo. S Slovenijo se je povezalo tudi Glasilo, ki je poskrbelo za dopisnika iz Ljubljane, junija 2014 pa se tudi promoviralo na prireditvi Dobrodošli doma ter vzpostavilo sodelovanje $\mathrm{z}$ nekaterimi slovenskimi mediji, npr. radijem Koper in radijem Veseljak, po zaslugi radia Glas, ki vzdržuje redne stike med radijem Glas in slovenskimi mediji prek Marije Ahačič Pollak. V letu 2015 je Slovenijo kolektivno obiskala še Slovenska šola v obliki maturantskega izleta. Zagotovo pa lahko trdimo, da so stiki z matico krepkejši, kot smo predvidevali, tudi $\mathrm{v}$ individualnih in zasebnih obiskih, ki so najbolj pogosti junija oz. v poletnem času, pri nekaterih vsakoletno, pri drugih občasno. V skupnem seštevku smo statusne spremenljivke za obdobje 2014-2015 ocenili za pol ocene višje kot po pilotski oceni vitalnosti, za 
demografske spremenljivke prav tako niti na terenu nismo uspeli pridobiti podatkov za statistično analizo, skupno oceno vitalnosti institucionalne podpore pa smo zvišali za eno oceno.

$\mathrm{V}$ predlaganem pristopu s pomočjo literarnega modela gre torej za dejanja krepitve slovenske narodne identitete $\mathrm{z}$ upoštevanjem participativnega modela. Model materialnih dejavnikov udejanjanja narodnega poziva za izseljensko skupnost zato deluje kot odlično sistematično orodje ali nekakšen daljnogled za opazovanje dejanj aktivnih področij v manjšinski skupnosti, kjer se potencialno uresničuje narodni poziv, urejanje le-teh ali implementiranje dodatnih, kar smo preverili z vnovično ocenitvijo vitalnosti skupnosti po Gilesovi taksonomiji. Pri tem je bilo ključnega pomena dvoletno poglobljeno terensko delo. Tovrstni pristop predlagamo za preučevanje slovenskih skupnosti, tako izseljenskih kot tudi zamejskih ter priseljenskih drugih narodnosti v Sloveniji; prav tako pa manjšinskih primerov vsake druge narodnosti.

\section{Viri}

Muller, Michael in Allison Druin. 2003. "Participatory Design: The Third Space in HCI.« <http://www.watson.ibm.com/cambridge/Technical_Reports/2010/TR2010.10\%20Participatory\%2O Design\% 2 oThe\% 2 oThird\%2oSpace\%2oin \% 2 o HCI.pdf.> (Dostop 29. 4. 2015)

Participatory Design. 2015. <http://en.wikipedia.org/wiki/Participatory_design>. (Dostop 29. 4. 2015)

\section{Literatura}

Čuš, Alenka. 2013. »Družbeni in prostorski vidiki identitete in jezikovne prakse (primer Slovencev v Torontu)«. Seminarsko delo. Koper: Univerza na Primorskem, Fakulteta za humanistične študije.

--- 2014. »Nov Veleposlanik, dr. Marjan Cencen, na delovnem mestu v Ottawi«. V Glasilo kanadskih Slovencev 19 (11): 15-21. Toronto: Vseslovenski kulturni Odbor.

James, William. 2002. Pragmatizem. Ljubljana: Krtina.

Kačičnik, Alenka. 2016a. »Dobrodelno kosilo VSKO Odbora v Hamiltonu«. V Glasilo kanadskih Slovencev 21 (15): 4-5. Toronto: Vseslovenski kulturni Odbor. 
---- 2016b »Minister Gorazd Žmavc na obisku v Kanadi«. V Glasilo kanadskih Slovencev 21 (17): 26-27. Toronto: Vseslovenski kulturni Odbor.

Lešnik, Bogdan. 1997. Subjekt v analizi. Ljubljana: ISH - Fakulteta za podiplomski humanistični študij.

Nećak Luk, Albina idr. 1998. Medetnični odnosi in etnična identiteta $v$ slovenskem etničnem prostoru. I, izsledki projekta. Ljubljana: Inštitut za narodnostna vprašanja.

Potocco, Marcello. 2012. Nacionalni imaginariji. Literarni imaginariji: različice nacionalnega poziva $v$ literaturi in $v$ literarnih kontekstih. Ljubljana: Pedagoški inštitut.

Strle, Urška. 2009. »Slovenci v Kanadi: izseljevanje skozi prizmo življenjskih zgodb «. Doktorska disertacija. Univerza v Ljubljani, Filozofska fakulteta, Oddelek za zgodovino.

Šimenc, Marjan. 2002. "William James, pragmatizem in resnica«. V Pragmatizem. William James: 209-224. 



\section{Primerjava jezikovnopolitičnega okvira}

in jezikovnih pravic narodnih skupnosti v Republiki Sloveniji in Kraljevini Švedski Študija primera na podlagi pregledane zakonodaje

Barbara Kopač

Filozofska fakulteta, Oddelek za slovenistiko, Univerza v Ljubljani Faculty of Arts, Department for Slovene Studies, University in Ljubljana barbi.uppsala636@gmail.com

Prispevek obravnava vprašanje narodnih jezikovnih manjšin, pri čemer izpostavlja njihov jezikovnopolitični okvir. Jezik je namreč danes eden temeljnih kazalnikov etnične pripadnosti in kot takšen igra podobno vlogo $\mathrm{v}$ mednarodni skupnosti kot nekdaj veroizpoved. $Z$ vlogo jezika znotraj manjšinskega vprašanja so se in se še danes ukvarjajo vse pomembnejše evropske in mednarodne institucije (Organizacija za varnost in sodelovanje v Evropi, Svet Evrope, Evropska unija in druge). Države in omenjene institucije so s sprejemanjem novih dokumentov o varstvu narodnih manjših in uveljavitvijo mehanizmov za njihovo uresničevanje pokazale, da mednarodni mir in stabilnost vsekakor neodtujljivo povezujejo $\mathrm{z}$ urejenim položajem manjšin.

Ključne besede: varstvo manjšin, mednarodna skupnost, manjšinsko vprašanje, Republika Slovenija, Kraljevina Švedska

Comparison of Language Policy Framework and Linguistic Rights of National Minorities in the Republic of Slovenia and the Kingdom of Sweden

Case study based on a review of legislation

The overall topic of this article is national linguistic minorities, within which it focuses primarily on their language policy framework. Language is one of the key indicators of ethnic affiliation 
and, as such, its role in an international community is as significant as the role of religion in earlier times. Its role within the minority question is studied by European and international organizations (Organization for Security and Co-operation in Europe, Council of Europe, European Union and others). The states and institutions mentioned above have issued new documents on minority protection and treaties on its implementation, which clearly shows that international peace and stability represent an inalienable part of minority status.

Narodne, rasne, verske, etnične in jezikovne manjšine so skozi celotno zgodovino sodobne mednarodne skupnosti predstavljale eno tistih vprašanj, s katerimi so se ukvarjali različni subjekti mednarodnih odnosov. Manjšinska vprašanja so posledično sooblikovala mednarodno skupnost, njihov pomen pa se skozi zgodovino ni pretirano spreminjal. Tudi v obdobju po hladni vojni, ko so prej obstoječe večnacionalne države nadomestile nove, enonacionalne države, so se $z$ manjšinsko problematiko še vedno ukvarjale vse pomembnejše evropske in mednarodne institucije (Organizacija za varnost in sodelovanje v Evropi - OVSE, Svet Evrope - SE, Evropska unija - EU in druge). Države in omenjene institucije so s sprejemanjem novih dokumentov o varstvu narodnih manjšin in uveljavitvijo mehanizmov za njihovo uresničevanje pokazale, da mednarodni mir in stabilnost neodtujljivo povezujejo $\mathrm{z}$ urejenim položajem manjšin.

Vendar pa se moramo pred poglobitvijo $\mathrm{v}$ termin zaščita manjšin ustaviti ob pojmu »manjšina«. Kaj je manjšina in kako jo pojmovati? Vsa ta vprašanja so seveda legitimna, vendar enovitega odgovora nanje ni mogoče podati, saj enotna definicija, kaj manjšina je, ne obstaja. Obstajajo dokumenti, ne pa tudi enotna opredelitev. Ta luknja v "univerzalnem zakonu" dopušča, da vsaka država po svoje opredeljuje manjšino, njene lastnosti in sam obseg, hkrati pa poglablja diskriminatorno pojmovanje manjšinskih skupnosti, kar posledično onemogoča sestavo enovite opredelitve termina. $\mathrm{Z}$ zanašanjem le na lastno interpretacijo pa je pravzaprav nemogoče objektivno in nediskriminatorno zaobjeti vse, kar manjšinska skupnost predstavlja.

\section{Metodološki okvir}

Čeprav se pričujoč prispevek osredotoča predvsem na jezikovni in politični okvir varstva manjšin, pa mimo pravnih razsežnosti ne moremo, saj je 
položaj (avtohtonih) narodnih skupnosti v Sloveniji in položaj (jezikovnih) manjšinskih skupnosti na Švedskem urejen s posebnimi mednarodnopravnimi pogodbami (Klopčič 2006, 59).

Slovenska nacionalna zakonodaja ponuja osnovo za implementacijo manjšinskih pravic že v primarnem državnem aktu, tj. v Ustavi, ${ }^{I}$ medtem ko švedska ustava ${ }^{2}$ temu poglavju ne namenja posebne pozornosti, daje pa toliko večji poudarek na mednarodne akte, med katerimi najbolj izstopata multilateralni pogodbi, ki predstavljata osnovo za uresničevanje manjšinskih pravic v mednarodnem prostoru - Okvirna konvencija Sveta Evrope za varstvo narodnih manjšin (v nadaljevanju Okvirna konvencija SE) in Evropska listina Sveta Evrope o regionalnih ali manjšinskih jezikih (v nadaljevanju Listina o manjšinskih jezikih).

\section{Oris in konceptualizacija problema}

Cilj prispevka je na podlagi pregledane zakonodaje pojasniti delovanje sistema varstva (avtohtonih) narodnih skupnosti v Republiki Sloveniji (RS) ${ }^{3}$ in v Kraljevini Švedski (KŠ) ter opredeliti vlogo jezika oziroma jezikovne politike $\mathrm{v}$ samem procesu. Jezik namreč igra pomembno vlogo pri oblikovanju in ohranjanju etničnih skupnosti, tako narodov kot narodnih manjšin (Roter v Komac 2007, 302). Gre za temeljni kazalnik etnične pripadnosti ter hkrati za močno vidno sestavino solidarnosti neke skupnosti (King 1997, 493-4). Jezik je na prehodu v novo tisočletje igral podobno vlogo kot nekdaj veroizpoved, $\mathrm{v}$ času, ko so bile $\mathrm{v}$ mednarodni skupnosti pomembnejše verske razlike oziroma ko je bila vez med suverenom in njegovimi podaniki v prvi vrsti verske narave (Roter 2001), danes pa se njegova vloga postopoma spreminja.

\section{Raziskovalno vprašanje}

Članek vseskozi izhaja iz naslednjega raziskovalnega vprašanja: Ali zanikanje pravice do uporabe lastnega jezika vodi v izgubo etnično-jezikovnega vidika družbe?

1 Ustava Republike Slovenije (RS), sprejeta 23. decembra 1991, v veljavi od 28. decembra 1991.

2 Ustava Kraljevine Švedske - Sveriges grundlagar, sprejeta 1974, v veljavi od 1. januarja 1975.

3 Ustava RS kot avtohtoni narodni skupnosti opredeljuje le italijansko in madžarsko narodno skupnost. Na slovenskem območju imamo sicer tudi pripadnike romske narodne skupnosti, vendar le-ta v Ustavi ni določena kot avtohtona. 
Jezik je neodtujljiv element vsake družbe. Je nekaj, kar jo opredeljuje, kar jo določa. Družba je brez jezika osiromašena do te mere, da je težko govoriti o kakršnikoli identiteti. A družba, predvsem sodobna, pravzaprav že v osnovi prepleta več različnih identitet in jezikov. Ali je govora o talilnem loncu ali zgolj o kulturni heterogenosti. V kolikor takšni družbi odvzamemo en jezikovni element, se (delno) spremeni tudi identiteta družbe. Vprašanje je le, v kolikšni meri.

Kulturni vidik družbe, poleg jezika, sestavlja še mnogo drugih elementov - vrednote, izročila, miselne in vedenjske vzorce, umetnost, književnost, način delovanja skupnosti ter samo udejstvovanje v skupnosti. Vsi ti elementi so del zgodovinskega spomina skupnosti, sestavljajo njeno kolektivno zavest (Heraud 1996, 55). A jezik kot eden izmed konstitutivnih elementov družbe vendarle izstopa. Je namreč sredstvo, s katerim se prenaša izročilo, je sredstvo sporazumevanja, je sredstvo, $s$ katerim se udejanja književnost. Heraud (prav tam) meni, da na Zemlji ne bi obstajala niti ena etnija, v kolikor bi vsi govorili le en jezik. Kar je dobro desetletje prej izpostavil že Južnič $(1983,19)$, ko je dejal, da je jezik pomemben pokazatelj različnosti, da človeka zaznamuje in da opredeljuje tudi njegov položaj v družbi. Kolikšen delež identitet bi se torej ohranil, če bi družbi odvzeli en, dva ali več jezikovnih elementov?

\section{Uporabljeni metodološki pristopi}

Metodološki pristop $\mathrm{k}$ področju preučevanja je interdisciplinaren. Uporabljeni so koncepti in metode, ki jih poznamo $\mathrm{v}$ znanosti o mednarodnih odnosih, mednarodnem pravu in družbenem jezikoslovju. Šele z njihovo sintezo je mogoče ustrezno odgovoriti na zastavljeno raziskovalno vprašanje.

\section{Obstoj narodnih manjšin}

Izraz manjšina se je uveljavil kot skovanka za označevanje domnevno problematične narave etničnih oziroma narodnih manjšin (Roter 2014, 17). Manjšine naj bi namreč predstavljale problem $\mathrm{z}$ nacionalnimi in mednarodnimi razsežnostmi - ne le danes, že v obdobju pred prvo svetovno vojno (Macartney 1934; Barker 1951, 56-7; Claude 1955; Chaszar 1988; Jackson Preece 1998). Ker so pojmovane kot (zelo) verjetna ovira pri izgradnji in ohranjanju nacionalnih držav, so razumljene kot problematične entitete $\mathrm{v}$ državah, saj naj bi ogrožale trdnost in stabilnost samih držav (Tilly 1975; 
Gellner 1983; Ra'anan et al. 1991; Hobsbawm 1992). Brown (1996) na podlagi zapisanega trdi, da se manjšinska problematika ne dotika le mednarodne varnosti, temveč tudi mednarodnega reda, norm in prava.

Manjšinske skupnosti so nastajale kot stranski proizvod oblikovanja mednarodnega sistema, kot trdi Petra Roter $(2014,90)$, in sicer predvsem pri velikih konfliktih oziroma vojnah, vključno s tridesetletno vojno $\mathrm{v}$ prvi polovici sedemnajstega stoletja, $\mathrm{z}$ napoleonskimi vojnami, vojnami na Balkanu ter $\mathrm{z}$ obema svetovnima vojnama. S premikanjem državnih meja, $\mathrm{z}$ nastajanjem, razpadanjem ali preoblikovanjem držav in njihovih zunanjih meja se je spreminjala tudi verska, jezikovna, etnična oziroma narodna identiteta prebivalstva $\mathrm{v}$ teh državah (prav tam). Vendar omenjena heterogenost nikoli ni bila obravnavana oziroma razumljena kot dejavnik stabilnosti, temveč prej obratno - dojeta je bila kot problem, kot razlog za interes drugih držav za vzpostavljanje "pravega stanja«, za vrnitev "pravega« prebivalstva, hkrati pa tudi kot razlog za izražanje interesa za dobrobit manjšinskega prebivalstva $v$ drugih državah, torej za vmešavanje v notranje zadeve držav z manjšinami (prav tam).

Skozi leta se je pojmovanje manjšin spreminjalo. Stalno meddržavno sodišče (Permanent Court of International Justice - PCIJ, pozneje preimenovano v Meddržavno sodišče - International Court of Justice (ICJ)) leta 1930 kot manjšinsko skupnost opredeli skupino ljudi z lastno tradicijo, rasno, versko in jezikovno osnovo ter z željo po ohranjanju teh običajev in tradicij. Memorandum Generalne skupščine Združenih narodov (GS ZN) v letu 1950 zgornji opredelitvi doda še pridevnik »specifična" - gre torej za specifično skupnost, ki se razlikuje od prevladujoče skupine v državi (v Smith 1991). V letu 1971 posebni poročevalec Organizacije Združenih narodov (OZN), Francesco Capotorti (Capotorti 1979), kot manjšino označi manjštevilčno skupino državljanov $\mathrm{v}$ nedominantnem položaju, ki ima drugačne etnične, verske ali jezikovne značilnosti kot dominantna skupina v tej državi, in ki kaže znake medsebojne solidarnosti v ohranjanju kulture, dediščine, religije in jezika (lahko tudi samo implicitno) - migranti, delavci (migranti), tujci in priseljenci ne spadajo zraven, niti dominantne skupine (27. člen Mednarodnega pakta o državljanskih in političnih pravicah). Capotorti (1979) pri opredeljevanju doda še pet obveznih konstitutivnih elementov za opredelitev neke skupnosti kot manjšinske - ta skupina mora živeti znotraj določene države, biti mora $v$ manjšini, pripadniki morajo biti državljani države, $\mathrm{v}$ kateri bivajo, njihove značilnosti morajo 
odstopati od povprečja, poleg tega pa mora obstajati želja po ohranjanju lastne tradicije in običajev.

Petrič v letu 1977 manjšinske skupnosti označi kot skupine ljudi določenih obeležij, bodisi narodnih, rasnih, etničnih ali jezikovnih, katerih položaj zahteva posebne ukrepe, skrb in pomoč, da bi lahko živeli enakopravno $\mathrm{z}$ drugimi prebivalci in ohranjali svojo narodnostno, kulturno in podobno identiteto (Petrič 1977). Jules Deschênes v letu 1985 poda podobno opredelitev, ki jo je v letu 1971 podal že Capotorti (1971) - razlika je predvsem v tem, da Deschênes (1985) uporablja izraz občani države (citizens), medtem ko se Capotorti poslužuje izraza državljani (nationals) (v Petrič 2010).

V prispevku je podanih le nekaj opredelitev, ki so dejansko kazale potencial, vendar pa se zaradi nestrinjanja držav glede opredelitvenih kazalcev niso uveljavile. Državam je tako pri opredeljevanju manjšinskih skupnosti še vedno dopuščena precejšnja svoboda.

\section{Jezikovne manjšine}

Petrič $(1977,91)$ meni, da so jezikovne manjšine, ki se podajajo na pot promocije lastnega jezika, v okviru etničnih študij ponavadi obravnavane kot etnične manjšine (in ne prav posebej kot jezikovne manjšine), posebne skupnosti ali celo narodi. Kljub vsemu pa ima jezik osrednjo vlogo pri oblikovanju tovrstnih skupnosti in hkrati pri posameznikovem opredeljevanju pripadnosti tej skupnosti. Ljudje, ki govorijo isti jezik, so po Petriču (2010) med seboj namreč precej bolj povezani kot tisti, ki pripadajo istemu družbenemu razredu, ideološkemu prepričanju ali poklicu.

$\mathrm{V}$ odnosu med etnično skupnostjo in jezikom gre torej za tesno vez, znotraj katere sta elementa soodvisna - eden brez drugega ne moreta obstajati. Slovenski jezik je bil namreč v zgodovini »tista določnica, po kateri je narod meril svojo vitalnost« (Roter 2008), in pomeni še danes, zlasti na obrobju slovenskega etničnega prostora, enega pomembnih znakov slovenske identitete. Enako velja tudi za italijanski in madžarski jezik, ki sta na slovenskem območju tudi ustavno obravnavana kot manjšinska jezika. Z uporabo omenjenih jezikov je italijanski oziroma madžarski skupnosti omogočeno ohranjanje lastne (italijanske oziroma madžarske) identitete tudi izven meja matične države (Komac in Roter 2015).

Ko vprašanje uporabe lastnega jezika znotraj tuje kulture obravnavamo $\mathrm{s}$ primordialističnega vidika, opazimo, da tovrstni pristop $\mathrm{v}$ odnosu do etnične (jezikovne) pripadnosti temelji na prepričanju, da imajo vsi pr- 
ipadniki etnične manjšine skupno poreklo. $\mathrm{V}$ tem primeru je to poreklo resnično (ne zgolj namišljeno) in trenutno predstavlja osnovo razumevanja odnosa med slovensko večino in italijansko oziroma madžarsko manjšino na ozemlju RS. Zagovorniki primordializma vidijo etničnost kot fiksno in kulturno podedovano, hkrati pa ji pripisujejo tudi neprostovoljnost (Škraba 2007, 18). Kritiki smeri pa opozarjajo, da je ravno ta element neprostovoljnosti tisto, kar ne dopušča možnosti, da bi bili ti ključni elementi etnične skupine zgodovinsko pogojeni in kulturno ustvarjeni. Prav tako menijo, da primordializem ne ponuja primerne razlage, zakaj se meje etničnih skupin spreminjajo (prav tam).

\section{Študija primera: Republika Slovenija in Kraljevina Švedska}

Mednarodne norme glede manjšin so se razvijale skozi celotno zgodovino sodobne mednarodne skupnosti, in sicer kot odraz prevladujočega (dominantnega) odnosa do nedominantnih skupnosti oziroma manjšin (Roter $2014,10)$. Sodobna mednarodna skupnost je heterogena, nanjo in na mednarodne odnose znotraj nje pa vplivajo različni akterji, tudi manjšine. Vendar pa so še vedno suverene, neodvisne države tiste, ki sprejemajo mednarodnopravne norme, vključno z normami glede varstva narodnih manjšin (prav tam). $V$ takšni mednarodni skupnosti so torej manjšine $v$ primerjavi z državami v neenakopravnem položaju, zato se po pomoč in zaščito zatekajo k svoji etnično sorodni državi, če le-ta obstaja.

\section{Republika Slovenija}

Ozemlje, na katerem je v začetku devetdesetih let dvajsetega stoletja nastala samostojna Slovenija, ni bilo nikoli etnično homogeno. S premikanjem političnih meja se je njihov obseg spreminjal, vendar pa so manjšinske narodne skupnosti na slovenskem vedno obstajale ( $\mathrm{v}$ manjšem ali večjem obsegu) (Komac 1999, 5). Podrobnejše definicije populacij, ki naj bi sodile pod režim manjšinskega varstva, ni mogoče podati na povsem nediskriminatoren način. Pristopov je toliko, da je edino, o čemer se lahko strinjamo kot navaja Komac (v Komac in Zagorac 2002, 17) - le to, da je vsem le malo skupnega.

Slovenska ustava $\mathrm{v}$ določenih členih omenja narodne skupnosti, posredno pa so prek ustave $\mathrm{v}$ določenem obsegu zavarovane tudi pravice skupnosti, ki niso priznane kot narodne (primer romske skupnosti) (Žurej 2004). Tudi status uradnega jezika ureja ustava, in sicer v svojem 11. členu, 
ki se glasi: »Uradni jezik v Sloveniji je slovenščina. Na območjih občin, v katerih živita italijanska ali madžarska narodna skupnost, je uradni jezik tudi italijanščina ali madžarščina." Ob obravnavi manjšinskih pravic in pravic, ki jih izvajamo iz jezika, je treba upoštevati še 14., 61. in 62. člen Ustave. Za svobodo izražanja, kamor sodi tudi svoboda izražanja prek medijev in kjer so posredno zaščitene tudi manjšine, pa je pomemben še 39. člen ustave RS, ki zagotavlja svobodo izražanja. Posebne pravice avtohtone italijanske in madžarske narodne skupnosti so omenjene v 64. členu, medtem ko 65. člen izpostavlja položaj in posebne pravice romske skupnosti v Sloveniji. ${ }^{4}$ Pri upoštevanju oziroma določanju manjšinskih pravic italijanske in madžarske narodne skupnosti ima pomembno vlogo tudi Zakon o samoupravnih skupnostih v Republiki Sloveniji, medtem ko ima največjo težo pri določanju pravic pripadnikov romske skupnosti Zakon o romski skupnosti iz leta 2007.5

\section{Kraljevina Švedska}

Cilj švedske manjšinske politike je varovati narodne manjšine ter krepiti njihovo moč, hkrati pa jim omogočati dejanski vpliv na uveljavljanje in ohranjanje manjšinskih jezikov. Na Švedskem so kot narodne manjšine priznani Judje, Romi, Sami, švedski Finci ter Tornedali. Manjšinski jeziki, ki jih skupine uporabljajo, so jidiš, laponski jeziki, romska narečja, finščina in meänkieli (Parkvall 2009). Manjšinska politika na Švedskem je bila kot samostojno politično področje osnovana v letu 2000, na podlagi odločitve Riksdag-a ${ }^{6}$ v letu 1999 za ratifikacijo Okvirne konvencije SE in Listine o manjšinskih jezikih. Stebri manjšinske politike so bili postavljeni tudi z vladnim Zakonom o narodnih manjšinah na Švedskem (1998/99:143). Priznanje manjšinskih jezikov pomeni, da so ti jeziki že del švedske kulturne dediščine (Runblom 1995).

Politika in načela pluralizma so pomenila zlom švedske tradicije, saj so se do začetka devetdesetih let načeloma vsi priseljenci zelo hitro prilagodili in osvojili švedsko kulturo. Tako poprej ni bilo govora o švedski heterogenosti, saj je bila država precej močna zavezana tradiciji homogenosti (Gustavsson in Runblom 1995, 208). Treba je poudariti, da so nove kulture sicer vplivale na švedsko gospodarstvo, vendar so bili ti vplivi bolj ali manj kratkoročni oziroma se niso obdržali dovolj dolgo, da bi lahko zamajali ste- 
bre švedske kulturne enotnosti - na primer, ko so v poznem osemnajstem stoletju na Švedsko prišli Judje, so sicer pustili pečat na gospodarstvu, vendar so se tako hitro prilagodili novemu okolju, da teh vplivov ni bilo mogoče čutiti (prav tam).

Švedska je stara država s trdno tradicijo »regionalne velesile«, osnovana na centralističnih načelih - ta načela pa so vsa podprta s Krono in Cerkvijo, kar se je še posebej okrepilo v času kralja Gustava Adolfa in v obdobju njegovih naslednikov (Gustavsson in Runblom 1995, 210). Pomembno je tudi dejstvo, da Švedska nikoli ni bila kolonialna sila, torej nima niti nobenih povezav $\mathrm{z}$ dekoloniziranimi območji, kar je, na primer, značilno za Nizozemsko in Veliko Britanijo (prav tam). Švedska je tudi versko enotna dežela - Nizozemska je, denimo, ustvarila modus vivendi med različnimi verskimi skupnostmi (med različnimi religijami).

\section{Uresničevanje državnih in mednarodnih dokumentov glede varstva narodnih skupnosti}

Odbor ministrov Sveta Evrope je povzel, da na osnovi predložene dokumentacije RS zagotavlja učinkovito zaščito narodnih in etničnih skupnosti, vendar pa še vedno ne dosega ravni, kjer bi bile omenjenim skupnostim zagotovljene vse (jezikovne) pravice in kjer bi bilo zadoščeno vsem določilom Okvirne konvencije SE. Največjo težavo predstavljata romska skupnost in njena visoka stopnja brezposelnosti, kar posledično vodi tudi v stanovanjski problem, zato odbor ministrov poziva RS, naj še naprej sledi določilom Okvirne konvencije SE ter o vsem napredku sproti obvešča svetovalni odbor. RS naj tudi okrepi zakonsko podlago za varstvo narodnih manjšin in etničnih skupnosti. Državi je svetovano tudi, naj se intenzivneje vklopi v kulturne programe, ki se jih izvaja za pripadnike narodnih manjšin in etničnih skupnosti. Z zadnjim sklepom odbora ministrov je bila RS pozvana, naj okrepi sodelovanje v Nacionalnem programu za Rome 2010-2015, naj poskrbi za pravni status vseh »izbrisanih«, naj podpre uporabo romskega jezika v pravnih in političnih procesih ter se hkrati osredotoči na posredovanje romske problematike širši javnosti prek raznih oblik medijev.

Sklep, ki ga je prejela KŠ, označuje državo kot zgledno v spoštovanju manjšinskih pravic. Po mnenju Sveta Evrope je Švedska že sprejela primerne ukrepe za utrjevanje sistema varstva manjšin, poleg tega pa se je v ustrezni meri osredotočila na manjšinske jezike in njihovo vlogo, saj imajo ti jeziki na Švedskem pomembno vlogo v izobraževalnih in političnih procesih. Nadzor nad uresničevanjem določil je prešibak, zato ga mora 
Švedska utrditi. Pripadnikom romske skupnosti se mora država intenzivneje posvečati, predvsem njihovim stanovanjskim problemom, izzivom z zaposlitvijo in, kot tudi RS, vlogi romskega jezika v družbi. Še vedno obstaja tudi izziv izobraževanja romskih otrok, saj je odstotek njihovega obiska šole (pre)nizek, enako pa velja tudi za romske iskalce zaposlitve - stopnja nezaposlenosti oziroma brezposelnosti je še vedno previsoka, poleg tega pa se država sooča tudi z visoko stopnjo decentralizacije, kar potegne za s seboj vso organizacijo.

\section{Sklep}

Pravice narodnih manjšin so bile vedno podrejene nacionalnim interesom in varnostnim vprašanjem znotraj držav ter hkrati tudi mednarodnemu redu in stabilnosti v mednarodni skupnosti. Iz pričujočega prispevka je očitno, da so narodne skupnosti opredeljene kot »nasprotje« - pravica narodnih skupnosti do samoodločbe in politične neodvisnosti nasproti pravicam suverene države do ozemeljske integritete in političnega nadzora nad vsemi prebivalci znotraj njenih meja ter reda in stabilnosti v državi. Načelo samoodločbe ni uresničljivo za vse in ga je težko doseči, predvsem zaradi ozemeljskih porazdelitev, ki jih zahteva. Narodne manjšine so tako živ dokaz, da praksa suverenih držav v modernem sistemu nacionalnih držav ni nujno skladna $\mathrm{z}$ načelom, ki jo legitimizira. Neuresničene politične ambicije narodnih manjšin, ki so bile prej v domeni notranjih zadev držav, so pridobile tudi mednarodno veljavo in sicer predvsem zaradi potencialno destruktivnega vedenja znotraj sistema nacionalnih držav (govora je o odceptivah, iredentizmu, vmešavanju matične države, tokovih priseljencev). V okviru mednarodnih odnosov so tako pravice manjšinskih skupnosti zgolj sredstvo za zmanjševanje teh destabilizacijskih učinkov.

Jezik v takšni družbi igra ključno vlogo - ne nastopa namreč le kot sredstvo sporazumevanja, marveč pripadnikom narodne skupnosti in pravzaprav vsakemu posamezniku v družbi predstavlja simbolno vez s kulturo, tradicijo, okoljem, ki mu pripada. V kolikor iz določene družbe, kjer bivajo pripadniki neke narodne skupnosti, jezik, ki ga ta skupina uporablja, odstranimo, odstranimo pomemben del njihove kulture. Jezik sicer ni edini element, ki to (takšno) družbo sestavlja, vsekakor pa je bistven in skupnost kot takšna brez njega težko deluje. Zanikanje do uporabe lastnega jezika lahko pri pripadnikih narodne skupnosti povzroči psihološki 
zlom, saj nadvlada tujega jezika simbolizira družbeno dominanco, zmago velesile nad svojo »kolonijo«. Poleg tega se izguba pozna tudi na tradiciji. Večina tradicionalnih obredov, če ne kar vsi, je izvedenih v domačem jezi$\mathrm{ku}$, torej v jeziku, ki je še do nedavnega predstavljal pomemben del njihove kulture. Ko se le-ta odstrani, se močno skrči tudi obseg tradicij in običajev. V kolikor bi se to razlagalo kot jagnje, ki ga je potrebno darovati zavoljo napredka, naj poudarim, da se napredek lahko doseže tako, da se pripadniki narodne skupnosti naučijo še drugega ali tretjega jezika in ne, da se znebijo svojega prvega jezika, torej materinščine.

$\mathrm{Na}$ podlagi opravljene raziskave lahko na raziskovalno vprašanje odgovorim pritrdilno - da, zanikanje uporabe jezika resnično lahko vodi $\mathrm{v}$ izgubo etnično-jezikovnega vidika družbe. $\mathrm{V}$ kolikor si smem dovoliti drzno izjavo - izguba, odstranitev ali zgolj zanikanje uporabe določenega jezika morebiti lahko pripelje celo do pojava, ki ga imenujemo brezidentitetna družba.

\section{Literatura}

Barker, Ernest. 1951. Principles of Social and Political Theory. Oxford: Clarendon Press.

Brown, Michael E. 1996. The international dimensions of internal conflict. CSIA Studies in International Security. Cambridge/London: The MIT Press.

Capotorti, Francesco. 1979. Study on the rights of persons belonging to ethnic, religious and linguistic minorities, Sub-Commission for Prevention of Discrimination and Protection of Minorities.

Chaszar, Edward. 1988. The international problem of national minorities. Indiana: Indiana University of Pennsylvania.

Claude, Inis L. 1955. National minorities: an international problem. Cambridge: Harvard University Press.

Deschênes, Jules. 1985. Proposal Concerning a Definition of the Term 'Minority' (UN Document E/CN.4/Sub.2/1985/31) - Predlog za osnutek Deklaracije Generalne skupščine Združenih narodov (GS ZN) o pravicah manjšin (E/ CN.4/Sub.2/1985/31). <http://www.jus.unitn.it/download/gestione/jens. woelk/20111010_19022011-02\%2Oconcepts2 definitions.pdf>. (Dostop 23. 9. 2016.)

Evropska listina o regionalnih ali manjšinskih jezikih - European Charter for Regional or Minority Languages, sprejeta 5. novembra 1992, v veljavi od 
1. marca 1998. <http://www.svetevrope.si/sl/dokumenti_in_publi kacije/ konven cije/148/>. (Dostop 23. 9. 2016.)

Gellner, Ernest. 1983. Nations and nationalism. Oxford: Basil Blackwell.

Gustavsson, Sven, in Harald Runblom, ur. 1995. Language, Minority, Migration.

Uppsala: Uppsala University, Centre for Multiethnic Research.

Hobsbawm Eric J. 1992. Nations and Nationalism since 1780: programme, myth, reality. Cambridge: Cambridge University Press, Second Edition.

Jackson Preece, Jennifer. 1998. National Minorities and the European NationStates System. London: Oxford University Press.

Južnič, Stane. 1983. Lingvistična antropologija. Ljubljana: Univerzum.

King, Charles. 1997. Policing language: linguistic security and the sources of ethnic conflict. Security Dialogue 28 (4): 493-496.

Klopčič, Vera. 2006. Mednarodnopravne razsežnosti pravnega varstva manjšin v Sloveniji. Ljubljana: Inštitut za narodnostna vprašanja.

Komac, Miran. 1999. Varstvo narodnih skupnosti v Republiki Sloveniji. Ljubljana: Inštitut za narodnostna vprašanja.

--- ur. 2007. Priseljenci. Ljubljana: Inštitut za narodnostna vprašanja.

---, in Dean Zagorac, ur. 2002. Varstvo manjšin: uvodna pojasnila in dokumenti. Ljubljana: Inštitut za narodnostna vprašanja.

---, in Petra Roter. 2015. The autonomy arrangement in Slovenia: an established institutional framework dependent on implementation of minority protection. V: Managing Diversity through Non-Territorial Autonomy: Assessing Advantages, Deficiencies and Risks, ur. Tove H. Malloy, Alexander Osipov, and Balázs Vizi, Oxford University Press, 93-115.

Petrič, Ernest. 1977. Mednarodnopravno varstvo narodnih manjšin. Maribor: Založba Obzorja.

--- 2010. Zunanja politika: osnove teorije in praksa. Ljubljana: ZRC Sazu.

Macartney, C. A. 1934. National states and national minorities. London: Oxford University Press and Humphrey Milford.

Mednarodni pakt o državljanskih in političnih pravicah - International Covenant on Civil and Political Rights, sprejet 16. decembra 1966, v veljavi od 23. marca 1976. <http://www.ohchr.org/en/professional interest/pages/ ccpr.aspx>. (Dostop 27. 9. 2016.)

Mednarodni pakt o ekonomskih, socialnih in kulturnih pravicah International Covenant on Economic, Social and Cultural Rights, sprejet 
16. decembra 1966, v veljavi od 3. januarja 1976. <http://www.ohchr.org/ EN/ProfessionalInterest/Pages/CESCR.aspx>. (Dostop 27. 9. 2016).

Okvirna konvencija za varstvo narodnih manjšin - Framework Convention for the Protection of National Minorities, sprejeta 1. februarja 1995, v veljavi od 1. februarja 1998. <http://www.svetevrope.si/sl/dokumenti_in_ publikacije/konvencije/157/>. (Dostop 23. 9. 2016).

Parkvall, Mikael. 2009. Sveriges språk - vem talar vad och var? Stockholm: Stockholm Universitet.

Ra'anan, Uri, Maria Mesner, Keith Armes, in Kate Martin, ur. 1991. State and nation in multi-ethnic societies. The breakup of multinational states. Manchester/New York: Manchester University Press.

Roter, Petra. 2001. Locating the "minority problem" in Europe: a historical perspective. Journal of International Relations and Development 4 (3), 221-249.

--- 2008. Spreminjajoči se pomen vsebine kriterijev opredeljevanja (narodnih) manjšin. Razprave in gradivo 2008 (56-57), 34-69.

--- 2014. Narodne manjšine v mednarodnih odnosih. Ljubljana, Fakulteta za družbene vede: Založba FDV.

Smith, A.D. 1991. Genealogija narodov. V Študije o etnonacionalizmu, ur. R. Rizman, 51-57. Ljubljana: Založba Krt.

Svet Evrope (SE) - Council of Europe (COE). <http://www.coe.int/en/>. (Dostop 26. 9. 2016).

--- Odbor ministrov. 2003. Sklep glede izvajanja Okvirne konvencije o varstvu narodnih manjšin Kraljevine Švedske, 10. december.

--- Odbor ministrov. 2005. Sklep glede izvajanja Okvirne konvencije o varstvu narodnih manjšin Republike Slovenije, 28. september.

--- Odbor ministrov. 2006. Sklep glede izvajanja Okvirne konvencije o varstvu narodnih manjšin Republike Slovenije, 14. junij.

--- Odbor ministrov. 2008. Sklep glede izvajanja Okvirne konvencije o varstvu narodnih manjšin Kraljevine Švedske, 11. junij.

--- Odbor ministrov. 2012. Sklep glede izvajanja Okvirne konvencije o varstvu narodnih manjšin Republike Slovenije, 4. julij.

--- Odbor ministrov. 2013. Sklep glede izvajanja Okvirne konvencije o varstvu narodnih manjšin Kraljevine Švedske, 11. junij.

Škraba, Urška. 2007. Integracija Romov v občini Grosuplje. Magistrsko delo, Univerza v Ljubljani, Fakulteta za družbene vede. 
The Protection of Minorities: Collected Texts. 1994. Strassbourg: Council of Europe.

Tilly, Charles. 1975. Reflections on the history of European state-making. V The formation of national states in Western Europe, ur. Charles Tilly, 3-83. Princeton: Princeton University Press.

Uradna stran švedskega parlamenta - Riksdag. <http://www.riksdagen.se/>. (Dostop 9. 9. 2016.)

Ustanovna listina Organizacije združenih narodov - The Charter of the United Nations, podpisana v San Franciscu 26. junija 1945, v veljavi od 24. oktobra 1945.

Ustava Kraljevine Švedske - Sveriges grundlagar, sprejeta 1974, v veljavi od 1. januarja 1975. <http://www.wipo.int/wipolex/en/details.jsp?id=11805>. (Dostop 4. 10. 2016.)

Ustava Republike Slovenije (RS), sprejeta 23. decembra 1991, v veljavi od 28. decembra 1991. <http://www.uradni-list.si/1/objava.jsp?urlid= 199133 \&stevilka=1409>. (Dostop 23. 9. 2016).

Zakon o narodnih manjšinah na Švedskem - Lag on svenska nationella minoriteter, sprejet 1998/99:143.

Zakon o romski skupnosti, sprejet 30. marca 2007, v veljavi od 28. aprila 2007. $<$ http://www.uradni-list.si/1/objava.jsp?urlid=200733\&stevilka $=1762>$. (Dostop 24. 9. 2016.)

Žurej, J. 2004. Pravice manjšin in jezikovne pravice v medijih v Republiki Sloveniji in v tujini. Revus 2 (2), str. 81-93. 


\section{Med vključevanjem in izključevanjem - vprašanje identitete $\mathrm{v}$ sodobnem slovenskem romanu v Italiji (I99I-20I6)}

Maja Smotlak

Znanstveno-raziskovalno središce Koper, Inštitut za jezikoslovne študije, Koper Science and Research Centre Koper, Institute for Linguistic Studies, Koper maja.smotlak@zrs-kp.si

Identitetno vprašanje se je $\mathrm{v}$ slovenskem romanu v Italiji od oblikovanja ideje slovenstva $v$ 19. stoletju, preko obdobja fašizma in po koncu 2. svetovne vojne osredotočalo predvsem na narodnost. Kaj pa po letu 1991 in po osamosvojitvi Slovenije? Ali je v tem izseku slovenske književnosti omenjeno vprašanje ostalo vezano predvsem na narodnost ali se je odločneje premaknilo na druga življenjska področja? Namen prispevka je preko razčlenjene analize poiskati odgovore na zastavljena vprašanja in s tem skozi perspektivo vprašanja identitete hkrati predstaviti pisanje sodobnih slovenskih avtorjev v Italiji, katerih romani so izšli v zadnjih šestindvajsetih letih.

Ključne besede: slovenski roman, slovenska književnost v Italiji, narodna identiteta, osamosvojitev Slovenije

Between Inclusion and Exclusion - the Issue of Identity

in the Contemporary Slovenian Novel in Italy (1991-2016)

Since the formation of Slovenian nationhood in the 19th century, through the period of fascism and after the end of the 2nd World War, the identity issue in the Slovenian novel in Italy had focused primarily on nationality. What about after 1991 and after Slovenia's independence? Has the above-mentioned issue in this segment of Slovenian literature remained tied primarily to 
nationality or has it decisively moved to other areas of life? The purpose of the paper is to find, through a structured analysis, answers to the questions raised with regard to identity and simultaneously to present the writing of the modern Slovenian authors in Italy, whose novels have been published in the last twenty-six years.

Key words: Slovenian novel, Slovenian literature in Italy, national identity, Slovenia's independence

\section{Izvori slovenskega romana $v$ Italiji in njegove povezanosti $\mathrm{z}$ narodno identiteto}

Slovenski roman $\mathrm{v}$ Italiji je bil skorajda od samega nastanka vsebinsko tesno povezan $z$ narodno identiteto. Zasnovan je bil ob izteku 19. stoletja, ko se je z zviševanjem ekonomskega standarda Slovencev na Tržaškem in Goriškem višala tudi njihova izobrazba in narodna zavest, kar se je kazalo $\mathrm{v}$ vse pogostejši rabi slovenskega jezika $\mathrm{v}$ zasebnosti, šoli, cerkvi in tisku. Povečalo se je število slovenskih časnikov in leposlovnih besedil. Dvaintrideset let za Jurčičevim Desetim bratom, prvim slovenskim romanom, je v še avstro-ogrskem Trstu pod psevdonimom Evgen Štefanič (v delih) izšel prvi slovenski tržaški roman Fata morgana (1898), ki ga je napisala Marica Nadlišek Bartol (1867-1940). V istem času se je slovenska literatura na Videmskem, na območju Nadiških in Terskih dolin, Rezije ter Kanalske doline, kjer je zaradi težje geografske dostopnosti vladal gospodarski in kulturni zaostanek, še naprej omejevala na nabožno književnost z elementi didaktičnosti in na ljudsko ustvarjanje narečnega, ustnega slovstva v obliki balad, pripovedi, pravljic, izštevank, rekov ter pesmi, povezanih z glasbo in plesi. Izjemo je predstavljal Ivan Trinko Zamejski (1863-1954), ki je z obsežnim izvirnim umetnostnim domoljubnim literarnim ustvarjanjem $\mathrm{v}$ slovenskem knjižnem jeziku učvrstil slovensko narodno identiteto med Beneškimi Slovenci.

Že v začetku 20. stoletja so se »[p]o zgledu političnega dogajanja na drugih večjezičnih in obmejnih področjih Avstrije [tudi na Tržaškem in Goriškem] ideološke, politične in socialne tematike umakn[ile] nacionalnemu problemu“ (Ara in Magris 2001, 68). Kljub zaostrovanju italijanskega iredentizma se je slovenstvo s svojim pripovedništvom na teh območjih utrjevalo in razvijalo. Za slovensko književnost $v$ Italiji in sploh njeno identifikacijo z omenjeno oznako je bilo ključnega pomena leto 1918, ko je Italija zavladala Julijski krajini, in leto 1920, ko je Rapalska pogodba še uradno 
potrdila slovensko oz. jugoslovansko in italijansko mejo. Novonastala jugoslovanska država je »manjšino ignorirala [...] [in] jo [...] prepustila usodi, kakršno ji je namenila fašistična Italija (Kacin Wohinz in Pirjevec 2000, 36).

Italijanski nacionalizem je izhajal iz ideje, da »fašizem in vse, kar ga obdaja, pomeni pristno italijanstvo, [...] kar pa je tuje svetu fašističnih vrednot, pomeni nasprotje domoljubja in prevratništvo " (Ara in Magris 2001, 149), zaradi česar je poskušal vsiliti monokulturnost in odpraviti vsakršno obliko slovenstva. Slovenski tisk je bil pod nadzorom, cenzuriran in s predpisi omejen "na religiozno, strokovno in glasbeno vsebino, brez političnih ali nacionalnih vsebin « (Kacin Wohinz in Pirjevec 2000, 60), dejansko pa je slovenska literatura v Italiji prav tedaj še bolj poglobila potrebo po obravnavanju narodnoidentitetnih vprašanj. Skoznjo se je odvijal boj piscev zoper cenzuro ter fašizem, ob čemer so se nazorske razlike brisale $\mathrm{v}$ prid narodnim interesom (Košuta 1997, 95).

Po letu 1945, s koncem 2. svetovne vojne, ni prišlo do prekinitve narodnega boja med Slovenci in Italijani, temveč se je ta nadaljeval na prikriti ravni. Kljub temu se je $\mathrm{v} 50$. letih slovenska književnost $\mathrm{v}$ Italiji odločneje razcvetela. Obnovile so se vse literarne zvrsti, še posebej pa se je razvila proza in v njej roman, »[n]jena najvidnejša avtorja, danes že klasika sodobne tržaške proze, sta [bila] Boris Pahor in Alojz Rebula« (Pirjevec 2011, 358). Slovenska literatura $\mathrm{v}$ Italiji se je $\mathrm{v}$ povojnem času še naprej nagibala $\mathrm{k}$ literariziranju narodne identitete, kajti »osebna in skupnostna ogroženost je bila v tem prostoru preveč resna, da bi slovenski književnosti dopuščala notranjo razpuščenost« (prav tam, 360). Premik oddaljevanja od močne osredotočenosti na narodno tematiko je bil izrazitejši pri mlajši generaciji piscev, ki jih »ni neposredno obremenjevala izkušnja s fašizmom» (Kacin Wohinz in Pirjevec 2000, 162), vendar so se ti do 8o. let bolj ali manj zadrževali pri kratkih pripovednih oblikah. V Beneški Sloveniji in Kanalski dolini so v povojnem času italijanske oblasti nadaljevale s sovražno politiko do slovenstva. Kljub neugodnim razmeram pa je tudi na teh območjih postopoma prišlo do pojavitve lokalnega založništva in tiska v slovenskem jeziku. Tamkajšnja slovenska literatura, ki se je šele tedaj sekularizirala in pluralizirala, je ostala vezana predvsem na pesništvo in dramatiko. Le redki ustvarjalci so se posvetili pripovedni prozi, še redkeje pa so se odločali za roman. ${ }^{\prime}$

Omenjena težnja se je nadaljevala tudi med letoma 1991 in 2016, ko ni izšel noben slovenski roman, ki bi ga napisal Slovenec z Videmskega. 


\section{Narodna in druge identitete v slovenskem romanu v Italiji po osamosvojitvi Slovenije}

Z osamosvojitvijo Slovenije leta 1991 se je za Slovence v matici z uresničenjem sna o slovenski državi dokončno potrdila narodna identiteta. Za Slovence v Italiji pa osamosvojitev Slovenije ni pomenila razrešitve narodnega vprašanja, ki se jim je ob tem zastavilo »v novi luči, in to tako v odnosu do samih sebe kot do drugih" (Mermolja 1998, 111). Res je, da je bil leta 2001 po štiridesetih letih pogajanj sprejet zaščitni zakon, ki se je pridružil vrsti drugih starejših zakonov, namenjenih zaščiti slovenske skupnosti v Italiji, vendar nedosledno udejanjanje tega ni niti zdaleč zadostilo dolgoletnim pričakovanjem. Leta 2004 je Slovenija vstopila v Evropsko unijo, leta $2007 \mathrm{v}$ schengensko območje, vendar se je kmalu izkazalo, da kljub administrativno-političnim ukrepom nekdanje »delitve puščajo sled v mentalnih zemljevidih Evropejcev in Evropejk« (Vidmar Horvat 2009, 159).

Potem ko je bila narodna identiteta dolgo časa osišče slovenskega romana $\mathrm{v}$ Italiji, je v času med letoma 1991 in 2016 prišlo do generacijske diferenciacije. $\mathrm{V}$ tem obdobju je $\mathrm{v}$ Italiji nastalo 48 slovenskih romanov 15 avtorjev. Romanopisci so: Boris Pahor (1913), Alojz Rebula (1924), Bojan Pavletič (1928-2009), Evelina Umek (1939), Irena Žerjal (1940), Sergej Verč (19482015), Marij Čuk (1952), Dušan Jelinčič (1953), Jasna Jurečič (1955-2014), Marko Sosič (1958), Igor Škamperle (1962), Vilma Purič (1966), Matjaž Klemše (1978), Vinko Bandelj (1987) in Erik Sancin (1981).

Omenjene avtorje lahko razvrstimo v tri skupine glede na odnos do narodne in drugih identitet, ki se kaže skozi njihove romane (slednje se v veliki meri prekriva $\mathrm{z}$ njihovo generacijsko pripadnostjo):

- 1. generacija avtorjev, rojenih med 1910 in 1945 - ohranjanje vezanosti na narodno identiteto,

- 2. generacija avtorjev, rojenih med 1946 in 1965 - razpetost med narodno in druge identitete,

- 3. generacija avtorjev, rojenih med 1966 in 1990 - zanimanje za identiteto $\mathrm{v}$ smislu iskanja lastnega jaza.

\section{Generacija avtorjev 1910-1945 in ohranjanje vezanosti} na temo narodne identitete

$\mathrm{Z}$ razvrstitvijo sodobnih slovenskih romanov $\mathrm{v}$ Italiji glede na leto rojstva romanopiscev se izkaže, da od 24 sodobnih romanov 7 romanov večidel starejših avtorjev, ki so osebno doživeli zatiranje slovenstva, ostaja veza- 
nih na temo narodne identitete. Med omenjene avtorje sodijo Boris Pahor (1913), Alojz Rebula (1924), Bojan Pavletič (1928-2010), Evelina Umek (1939) in Irena Žerjal (1940). Narodno identiteto pogosto postavljajo v središče svojih pripovedi. Posvečajo se ji neposredno in poglobljeno. Posebnost te skupine sta romana Marija Čuka (1952), Pena majskega vala (1998) in Molk koloradskih hroščev (2016), ter roman Vilme Purič (1966), Burjin čas (2009), pripadnikov srednje in najmlajše generacije, $\mathrm{v}$ katerih je narodna identiteta prav tako poglavitnega pomena.

Za romane te vrste je značilno, da je narodna identiteta predstavljena kot izjemno zavezujoča in pomembna. Kot zapiše Boris Pahor v romanu Zgodba o reki, kripti in dvorljivem golobu (2003), je to »dragocena vrednota« (Pahor 2003, 216), "precej zanesljivo poroštvo za prihodnost« (prav tam). Narodno identiteto običajno spremlja vrednota človeškosti, ostale vrednote, kot so zasebnost (ljubezensko in družinsko življenje) ter politične ideologije, pa so ji izrazito podrejene. Literarni liki zavračajo politično ideološko razdvojenost, zaradi katere je narod oškodovan. Osredotočanje na ideološka razhajanja je, kot ugotavlja Pahorjev protagonist in alter ego Igor Sevken, »za skupnost, ki živi [...] v tuji državi, avtolezionizem’" (prav tam, 224). Liki svoje zasebne izbire pogojujejo $\mathrm{z}$ razlogi, povezanimi $\mathrm{z}$ narodom, ali pa dajejo narodu prednost pred temi. Tako na primer v romanu Irene Žerjal Magnetofonski trak (1994) Demon, Slovenec v emigraciji, našteva Slovenki iz Italije, Nataši, eni od mnogih protagonistk romana, med pomembnimi stvarmi, ki ju združujejo, tudi narodnost: »'Sva istega okusa, iste narodnosti, istih čustev’" (Žerjal 1994, 70). V romanu Vilme Purič Burjin čas pa se protagonistka, Slovenka Brina, v 2. svetovni vojni odreče ljubezni do Italijana, saj se ta znajde na strani fašizma, ona pa sodeluje s partizani.

Za omenjene avtorje je značilno, da k vprašanju narodnosti pristopajo tako, da se osredotočajo na opredeljevanje pozitivnih in negativnih narodnih identitet. Pozitivna narodna identiteta je praviloma zanje tista, ki je $\mathrm{v}$ določeni meri vrojena in vgrajena $\mathrm{v}$ posameznika mimo njegove volje in zavesti, je nespremenljiva in nenadomestljiva, posameznik pa mora poskrbeti, da ostaja jasno definirana in ekskluzivna. Pri prikazovanju takšne narodne identitete so avtorji izrazito slovenocentrični, pri čemer je slovenstvo ubesedeno kot narodnost, ki zahteva veliko žrtvovanja, borbe, truda, trpljenja in odpovedovanja, kar ji obenem podeljuje privilegiran, čast- 
ni položaj, dragocenost, ekskluzivnost in prestiž. ${ }^{2}$ Negativne narodnosti prikazujejo preko nejasno definiranih, labilnih, vsiljenih, zatajenih, sestavljenih (slovensko-italijanskih) ali neslovenskih (italijanskih, mestoma nemških) narodnih identitet. Te avtorji nemalokrat zvežejo $\mathrm{z}$ negativnimi duševnostmi in problematičnimi, moralno izprijenimi značaji literarnih likov, ki so bolj kot drugi nagnjeni k zakonski nezvestobi, šovinizmu, oportunizmu, vohunjenju, omahljivosti, nerazgledanosti, napetosti, zmedenosti, značajski šibkosti. Razlika med trdno in iznakaženo narodno identiteto je najbolj nazorno prikazana v romanu Eveline Umek Zlata poroka ali Tržaški blues (2010) preko Saške, ki je bila vzgajana v slovenstvo, in njenega brata Bruna, za katerega je oče izsiljeval izključno italijansko vzgojo v sovraštvu do Slovencev, medtem ko si je mati želela, da bi bil vzgajan tudi $\mathrm{v}$ slovenstvo.

Saška [je bila] tako trdna v sebi, vedela je, kaj hoče in se je bila pripravljena za svoj cilj tudi žrtvovati. Ubogi Bruno je kmalu postal Fiorejeva igračka in orodje. Lastil si je otroka in ga begal. Pogledala ga je in zasmilil se ji je. [...] Ker ga trgata vsak na svojo stran, ni nikogaršnji. Še sam svoj ne. (Umek 2010, 105)

Najbolj negativno je prikazano narodno odpadništvo in zatajevanje izvorne narodne identitete, za prikaz česar avtorji uporabijo največkrat tržaške meščane, ki poudarjajo svojo tržaškost in italijanstvo, zato da bi z njima prikrili svoje slovensko narodnostno jedro, ki ga zavračajo. Romanopisci opozorijo na lažnost in praznost kategorije tržaškosti, ki je po njihovem mnenju v resnici nujno vezana na neko narodnost (slovensko, italijansko, hrvaško, judovsko, češko itd.). Na primer v romanu Alojza Rebule Kačja roža (1994) eden od literarnih likov opozarja na zatajeno slovenstvo Tržačanov z opazkami, kot so: »V možu se je seveda skrival Slovenec, čeprav je zoževal samoglasnike po naše: pač tukajšnja mimikrija« (Rebula 1994, 82-83), »v Trstu, v tej mali Babiloniji, ima komaj kdo izviren italijanski priimek razen [...] priseljencev s polotoka« (prav tam, 115).

Starejši avtorji, ki se $\mathrm{v}$ svojih delih večidel ukvarjajo s (slovensko) narodno identiteto, iščejo tudi njene temeljne narodnoidentifikacijske sestavine. Te prepoznavajo $\mathrm{v}$ slovenskem jeziku, kolektivnem spominu

Zahtevnost slovenstva naj bi na podlagi romanesknih prikazov izhajala iz več faktorjev: majhnosti, neuveljavljenosti v mednarodnem okviru, demografskih težav, asimilacije, agresivnosti sosednjih narodov, soočanja $\mathrm{z}$ zapleteno narodno preteklostjo, narodu inherentnih konfliktov, samouničevalne težnje in nedodelane narodnoutrjevalne politike. 
(poudarjajo spomin na obdobje fašizma, nacizma in 2. svetovne vojne), kulturi (literaturi, upodabljajoči umetnosti in glasbi), ozemlju ter državi. Vse so zanje zelo zavezujoče.

\section{Generacija avtorjev 1946-1965 in razpetost med narodno in druge identitete}

Med romane generacije, rojene med letoma 1946 in 1965, spada 20 romanov 5 piscev, Sergeja Verča (1948-2015), Dušana Jelinčiča (1953), Jasne Jurečič (1955-2014), Marka Sosiča (1958) in Igorja Škamperleta (1962). Gre za avtorje, rojene po koncu 2. svetovne vojne, ki niso občutili na lastni koži neposrednega raznarodovalnega pritiska fašizma in najbrž tudi zaradi tega ne čutijo več tako močne potrebe po ubesedovanju narodne identitete. Narodna identiteta je $v$ njihovih romanih še prisotna, a manj zavezujoča. Podrejena je drugim vrednotam, kot so zasebnost, človeškost in (a)politične ideologije, enakopravnost, empatija, pacifizem.

Prvi od osrednjih likov sodobnega slovenskega romana v Italiji, ki se uspe čustveno oddaljiti od pretirane zavezanosti lastni izvorni narodni identiteti, ne da bi jo zatajil in izničil, je protagonist štirih kriminalnih romanov Sergeja Verča, slovenski komisar Benjamin oz. Beno Perko, zaposlen v italijanski policiji. V romanu Rolandov steber (1991) Beno ob vračanju v rodni Trst ugotavlja, da se je s premestitvijo na delovno mesto na jug Italije $\mathrm{v}$ precejšnji meri uspel razbremeniti zavezujočnosti in poudarjanja narodne identitete. Pomembnejše so mu postale druge vrednote kot na primer pravičnost, politične ideološke opredelitve in zasebnost.

V svojih devetih sodobnih romanih Dušan Jelinčič izriše svet izpraznjenih idealov, v katerem pa kljub temu osrednji literarni liki spoznajo, da je v njem vendarle vredno iskati in gojiti vrednote družine, ljubezni, empatije in človečnosti, pa tudi narodnosti, vendar na zmeren, intimen in diskreten način. V imenu naroda namreč ni vredno netiti konfliktov, saj gre pri tem za »umetno ustvarjeni dualizem, da lahko imaš potem sovražnika, proti kateremu se lahko boriš in vzgajaš svoje otroke v mržnji in sumničenju« (Jelinčič 2007, 255). Zelo visoko vrednost družini in njeno izrazito prednost pred narodom Jelinčič izpostavi v romanu Martin Čemur (2002). V njem je izražena kritika istoimenskemu osrednjemu liku, ki zanemarja in žrtvuje intimne vezi ter osebne ambicije $\mathrm{v}$ imenu naroda, kar ga privede do propada. Medtem ko v svojih gorniških in pogosto avtobiografskih romanih pošlje protagonista, Slovenca iz Italije, $v$ gore tudi zato, ker se ta želi oddaljiti od utesnjujočega in zlaganega okolja, v katerem manjšinska skup- 
nost vzgaja bolj v javno poveličevanje narodnosti, torej v igrani videz, kot pa $\mathrm{v}$ iskreno čutenje.

V edinem romanu Jasne Jurečič Prerokuj mi še enkrat (2008) je prednjačenje zasebnosti pred narodnostjo najbolj razvidno iz dejstva, da se v njem protagonistka, Slovenka iz Italije, poroči z Italijanom, ne da bi se ozirala na zlobno opravljivost slovenskih sovaščanov, ki za njenim hrbtom govorijo: »S Taljanom se je spečala, sn znala jest, ni moglo končat drugače [...]! Kaku, kaku da ne znaš, znajo vsi!« (Jurečič 2008, 28). Intimni odnosi so zatočišče pred svetom, ki se na podlagi spolnih, socialnih, ideoloških in drugih delitev drobi na ločene mikroskupnosti.

Nadvlada in moč narodne identitete je ošibljena na povsem svojevrsten način v romaneskni trilogiji Marka Sosiča, in sicer z ubiranjem specifičnih prvoosebnih pripovednih perspektiv oz. nezanesljivega pripovedovalca (prim. Harlamov, 2010). V Balerini, balerini (1997) pokaže na konstruiranost narodnosti in relativnost njene vrednosti prek pripovedne perspektive duševno zaostale protagonistke. V romanu Tito, amor mijo (2005) preko perspektive desetletnega dečka prikaže željo mlajših generacij, da bi svobodneje živele vezanost in odgovornost do narodne identitete, ne da bi jo povsem izničile. V romanu Ki od daleč prihajaš v mojo bližino (2012) je želja po oddaljitvi od narodnega $\mathrm{v}$ prid drugim vrednotam radikalizirana $\mathrm{v}$ pogledu psihično motenega protagonista, profesorja naravoslovja Ivana Slokarja. Protagonist obsoja očeta, ker ta narodno identiteto vztrajno postavlja pred empatijo do bližnjega, potrebnega pomoči. Ivanov odpor do očetovega ravnanja sproži v njem nestrpnost do vsakogar, ki pripisuje velik pomen slovenstvu.

Preobrnjeno lestvico vrednot vključi tudi Igor Škamperle v svoja dva romana, Sneg na zlati veji (1992) in Kraljeva hči (1997). Bolj kot vprašanje naroda se njegovim protagonistom zdi potrebno »[m]oralno prenoviti svet. To je tisto, kar bi morala Evropa že zdavnaj storiti, pa tega ni znala ali ni hotela « (Škamperle 2002, 281), kajti sodobni čas ne pozna idealov, »[m]oderna Evropa, to se pravi svet, v katerem živimo, temelji na bančnem sistemu« (prav tam, 41).

Predstavljeni avtorji ob znižanju vrednosti narodne identitete v korist drugim vrednotam prikažejo tudi raznolikost in pluralnost sodobnih odnosov do naroda, ki nemalokrat stopajo $\mathrm{v}$ medsebojno kontradikcijo, ko se na eni strani ljudje identificirajo vse pogosteje $\mathrm{z}$ narodu nadrejenimi identitetami, na drugi pa se ohranjajo pri življenju narodno zaprte, v nekaterih primerih celo neonacistično usmerjene skupnosti. Problem, ki jih v 
okviru nadnarodnih, identitet posebej vznemirja, je globalizacija s svojimi protislovji, številnimi, vendar le začasnimi, pogosto lažnimi in površinskimi nadnarodnimi povezovanji, za katerimi se $\mathrm{v}$ resnici skrivajo ekonomski in oblastniški interesi maloštevilnih elitnih posameznikov. Jelinčič in Škamperle na primer prepoznavata, da nekdanje narodne delitve nadomeščajo delitve na nove nasprotujoče si binome Zahod in Vzhod sveta, Sever in Jug sveta, Zahod in Vzhod Evrope, kapitalizem in socializem, militarizem in pacifizem. Zahod, Sever, kapitalizem in militarizem so tisti, ki tvorijo negativni pol sveta, izkoriščajo nasprotno stran, do nje gojijo številne predsodke in so vzvišeni. Vzhod, Jug, socializem in pacifizem predstavljajo pozitivno stran sveta, ki je postavljena v neugodne okoliščine in podrejeni položaj.

\section{Generacija avtorjev 1966-1990 in zanimanje za identiteto v smislu iskanja lastnega jaza}

Med romane najmlajših avtorjev je mogoče prištevati 4 dela 4 piscev, in sicer Vilme Purič (1966), Matjaža Klemšeta (1978), Vinka Bandlja (1987) in Erika Sancina (1981). ${ }^{3}$ Za njihove romane je v primerjavi s predhodniki značilen popoln obrat $\mathrm{v}$ pristopanju $\mathrm{k}$ vprašanjem identitete, ki se kaže $\mathrm{v}$ odsotnosti narodnega vprašanja. Narodna identiteta je le ena od identitet in vrednot kolektivnosti, ki so v sodobni razdrobljeni, nihilistično naravnani družbi popolnoma zrelativizirane ali izničene. V sodobnem svetu namreč soobstajajo druga mimo druge hibridne narodne identitete, narodne identitete, ki poudarjajo svojo ekskluzivnost, in pogledi, ki nadomeščajo narodne identifikacije $\mathrm{z}$ drugimi nadrejenimi (npr. nadnarodnimi identitetami) ali podrejenimi kategorijami (npr. regionalnimi identitetami), kar vodi v krizo identifikacijskih kategorij. Narodne in nadnarodne identitete $\mathrm{v}$ njem nimajo več nikakršne globlje veljave, so nepomembne in nedefinirane, nezanesljive, zgolj površinske, navidezne in začasne, kar povzroča, da se človek počuti razsrediščen. Protagonisti so tako resignirani nad poskusom iskanja kakršnihkoli kolektivnih identitet, vrednot in sestavljanjem vrednostnih hierarhij. Edino, kar jih še zanima kot predmet raziskovanja, so oni sami, njihov notranji, psihični, duševni svet. Ne zastavljajo

3 Število najmlajših slovenskih romanopiscev v Italiji, rojenih po letu 1965, je zelo nizko, pri čemer je še posebej problematična zastopanost pisateljic. Poleg tega pa je za omenjene avtorje značilno, da napišejo le po en roman in nato prekinejo svojo literarno dejavnost; izjemo med njimi za zdaj predstavlja le Vilma Purič, ki je do leta 2016 napisala dva romana. 
si več vprašanj o preteklosti, sedanjosti in prihodnosti Slovencev v Italiji, temveč se podajajo na pot raziskovanja samih sebe in preizprašujejo lastno usodo, kar jih včasih privede do skrajno kriznih stanj. Enega od teh doživlja Lana, protagonistka romana Vilme Purič Brez zime (2012), ko prestaja hudo, neobvladljivo eksistencialno stisko, ki jo privede do tragičnega konca. Tudi Klemšetov protagonist avtobiografskega romana $V$ zakrpanih gojzarjih (2009) se po hudem rakavem obolenju, ki ga je spravilo v smrtno nevarnost, sam odpravi na pot do samega sebe, ki je hkrati pot po slovenski planinski poti ali transverzali od Maribora do Ankarana. Med pešačenjem po Sloveniji se priložnostno druži z drugimi pohodniki, predvsem pa razmišlja o svoji preteklosti in medčloveških odnosih, v katere je vpleten. Zelo podobno se tudi Sancinov Luca, pripadnik subkulture apolitičnih obritoglavcev in edinstveni primerek protagonista italijanske narodnosti, ${ }^{4} \mathrm{v}$ romanu Nekje sredi vročine (2003) potika po različnih koncih Evrope. Ta se ne poglablja v svojo psiho in notranja doživljanja, toda njegovo bežanje pred samim seboj, družinskimi razprtijami in krizo smisla je mogoče posredno razbrati iz dekadentne razpetosti »med pijančevanjem, seksom in vandalizmom «(Bandelj 2010, 15). Po poletnem potepanju po Evropi se vrne v domači Torino, ne da bi bilo njegovo življenje deležno kakršnekoli bistvene spremembe $\mathrm{v}$ primerjavi s stanjem, v katerem je bil pred odhodom. V romanih najmlajših avtorjev torej izstopa stiska ob posameznikovem iskanju orientacije v »novem«, identitetno pluralnem, prehodnem in razdrobljenem svetu, na katerega se po dolgem obdobju življenja v jasno zamejenih identitetah sodobni človek šele privaja.

Povsem samosvoj med najmlajšimi pisci pa je Vinko Bandelj s svojim romanesknim prvencem Grad in čas (2016). V njem se v celoti oddalji od človeških problemov, tudi od vsakršnih identitetnih tematik, in se posveti predmetnemu svetu. Preko različnih besedilnih vrst, ki gredo od vzorcev pravljice in legende, pesmi $\mathrm{z}$ nadihom ljudske tradicije preko zgodovinskega poročila do klasične pripovedi, prikaže zgodbo gradu, imenovanega Volčjak, in narave, ki ga obdaja, kot krožen proces nastajanja, obstajanja, uničenja in obnavljanja; »[o]d peščene usedline do skale. Od skale do griča. Od griča do grada, in spet nazaj. Od grada do peščene usedline« (Bandelj 2016, 154).

4 Slovenski romanopisci v Italiji se večinoma odločajo za protagoniste, ki so Slovenci iz Italije.

5 Bandljev roman Grad in čas bi bil lahko zelo zanimiv tudi za ekokritiko, novo literarnovedno disciplino, ki proučuje povezavo med literaturo in fizičnim okoljem, 


\section{Zaključek}

Že zelo zgodaj je bil slovenski roman $\mathrm{v}$ Italiji tesno povezan $\mathrm{z}$ literariziranjem narodne identitete, zlasti od nastopa italijanskega fašizma in njegovega preganjanja slovenstva dalje. Trdna naveza je trajala vse do osamosvojitve Slovenije leta 1991, s katero je prišlo do generacijske diferenciacije med avtorji, ki so objavili svoje romane med letoma 1991 in 2016.

Starejši avtorji, rojeni med letoma 1910 in 1945, ki so osebno doživeli fašistično nasilje nad Slovenci, so tudi v svojih najsodobnejših delih ostali vezani na temo narodne identitete. Narod ostaja za njihove protagoniste še naprej najvišja vrednota, ki presega vse ostale. Poleg tega pa je njihov pogled slovenocentričen. Pri definiranju pozitivnih in negativnih narodnih identitet je pozitivna identiteta trdna in slovenska, medtem ko so negativne identitete nejasne, zatajevane, sestavljene (npr. slovensko-italijanska) ali neslovenske (npr. italijanska, nemška). Najbolj negativno je ocenjeno narodno odpadništvo.

Srednja generacija piscev, rojenih med letoma 1946 in 1965, ni doživela narodne ogroženosti na način, kot so jo starejši, kar se odraža tudi v dejstvu, da njihovi literarni liki občutijo narodno identiteto kot manj zavezujočo in nič več podrejeno drugim, pomembnejšim vrednotam (npr. družini, zasebnosti). V sodobnem svetu s kritičnostjo zaznavajo pluralnost in raznolikost odnosov do naroda, globalizacijo ter njene nadnarodne delitve (Zahod-Vzhod, Sever-Jug, kapitalizem-socializem, militarizem-pacifizem). Ob tem izražajo potrebo po moralni prenovi sveta.

Največji premik stran od dolgoletne tradicije zvezanosti slovenskega romana $v$ Italiji s tematizacijo narodne identitete je opazen pri najmlajših romanopiscih, rojenih med letoma 1966 in 1990. Pri teh je narod odsoten, saj namesto tega nastopi vsesplošna kriza identitetnih kategorij, razsrediščenje literarnih likov, postavljenih v nihilistično družbo. Tem ostane edino še zanimanje za spoznavanje samih sebe, lastnega psihičnega in duševnega sveta, pri čemer pa se pogosto kljub prehojeni poti introspekcije nazadnje znajdejo na izhodiščni spoznavni točki. Ob iskanju orientacije v »novem « svetu identitetne razdrobljenosti, hitrih in težko obvladljivih sprememb, za zdaj ostajajo ujeti v brezizhodno stisko. 


\section{Viri}

Bandelj, Vinko. 2016. Grad in čas. Trst: Založništvo tržaškega tiska.

Jelinčič, Dušan. 2007. Kam gre veter, ko ne piha. Piramida. Maribor: Litera.

Jurečič, Jasna. 2008. Prerokuj mi še enkrat. Trst: Mladika.

Pahor, Boris. 2003. Zgodba o reki, kripti in dvorljivem golobu. Maribor: Litera.

Rebula, Alojz. 1994. Kačja roža. Ljubljana: Mihelač.

Škamperle, Igor. 2002. Kraljeva hči. Koper: Lipa.

Umek, Evelina. 2010. Zlata poroka ali Tržaški blues. Trst: Mladika.

Žerjal, Irena. 1994. Magnetofonski trak. Bor. Trst: Slovenska gospodarsko-prosvetna skupnost.

\section{Literatura}

Ara, Angelo, in Claudio Magris. 2001. Trst, obmejna identiteta. Knjižna zbirka Claritas. Ljubljana: Študentska založba.

Bandelj, David. 2010. „Sodobna proza Slovencev v Italiji: tipologije romana 1980-2010«. V Sodobna slovenska književnost (1980-2010), ur. Alojzija Zupan Sosič, 11-17. Ljubljana: Znanstvena založba Filozofske fakultete.

Harlamov, Aljoša. 2010. »Nezanesljivi pripovedovalec v sodobnem slovenskem romanu«. Jezik in slovstvo 55 (1-2): 33-46.

Kacin Wohinz, Milica, in Jože Pirjevec. 20oo. Zgodovina Slovencev v Italiji 1866-20oo. Korenine. Ljubljana: Nova revija.

Košuta, Miran. 1997. Scritture parallele: dialoghi di frontiera tra letteratura slovena e italiana: studi e saggi. Trieste: Edizioni Lint.

Mermolja, Ace. 1998. Narod in drugi. Smeri. Trst: Založništvo tržaškega tiska.

Pirjevec, Marija. 2011. »Periodizacija slovenske književnosti na Tržaškem (od 16. do 20. stoletja)«. Annales: anali za istrske in mediteranske študije. Series historia et sociologia 21 (2): 353-362.

Vidmar Horvat, Ksenija. 2009. Zemljevidi vmesnosti: eseji o evropski kulturi in identiteti po koncu hladne vojne. Sodobna družba. Ljubljana: Sophia. 


\section{Gledališče na stičišču kultur}

Slovensko stalno gledalǐ̌če v Trstu v času po drugi svetovni vojni

\section{- uprizoritve, razmerja, položaj in usoda}

Rok Andres

Fakulteta za humanistiko, Univerza v Novi Gorici School of Humanities, University of Nova Gorica rokandres@gmail.com

Gledališka dejavnost v Trstu se je profesionalizirala v času ustanovitve Dramatičnega društva v letu 1902, bila nasilno prekinjena s požigom Narodnega doma (1920) in ponovno vzpostavljena s koncem leta 1945. Tržaško gledališče je ključno prispevalo k narodni identiteti in tudi $\mathrm{k}$ razvoju uprizoritvenih praks. $\mathrm{V}$ članku obravnavamo čas po drugi svetovni vojni, ki je prelomen v svoji estetiki in avtorskih pristopih. Uvrstitev $\mathrm{v}$ repertoar je oblika recepcije, ki nam pokaže, koliko je neko gledališče sodobno, kam je usmerjena njegova dejavnost ter kako se želi profilirati v umetniškem izrazu. Analiza repertoarja Slovenskega stalnega gledališča Trst, ki ga primerjamo z osrednjo nacionalno gledališko hišo SNG Drama Ljubljana, bo prikazala stanje na obeh straneh meje in razlike med dvema gledališčema, ki jim bomo dodali še primerjavo z italijanskim gledališčem Rosseti iz Trsta. Gledališče, ki deluje za celoten zamejski prostor, stik s publiko ohranja $\mathrm{z}$ uprizarjanjem del, ki se ukvarjajo s problemom manjšine in preizpraševanjem te problematike $\mathrm{v}$ jeziku uprizoritve. Tržaško gledališče, gledališče na stičišču kultur, je študijski primer razmerja med središčem in obrobjem, večino in manjšino, zahodom in vzhodom ter zaradi teh silnic sinteza zgodovine slovenske uprizoritvene umetnosti.

Ključne besede: Slovensko stalno gledališče Trst, tržaško, zahodnoevropski dramatiki, stičišče kultur 


\section{Theatre at Cultural Junctures}

Slovensko stalno gledališče in Trieste in the period after World War II - the performances, relations, its state and fate

Theatre activity in Trieste has a long history. The first known performance by the Slavljansko Society dates back to 1848 , but professional organizations originated with the establishment of the Dramatic Society in 1902. Theatre production was violently interrupted by the burning of the Narodni dom (1920) and not re-established until the end of 1945. The Slovene Theatre in Trieste has made a vital contribution to the national identity and to the development of performance practices in the region and beyond. In this article, we investigate the period after the Second World War, which was a significant time because of its aesthetic and artistic approaches. The theatre repertoire is a form of reception that shows how modern or up-to-date a theater is and its profile in terms of its artistic or aesthetic expression. We will analyse the repertoire of the SSG Trieste, comparing it with the National Theatre (SNG Drama) in Ljubljana and the analysis will present the state of mind on both sides of the border, namely, the differences between the two theatres. Theatre that works for the entire Slovene minority in Italy is turning to his audience by staging works that deal with the problem of minorities and question these problems with the language of the theatre. Theatre in Trieste theatre at a cultural juncture - is a case study of the relationship between central area and periphery, majority and minority, the west and the east and with these relations we can foresee the synthesis of the history of Slovenian performing arts.

Key words: Slovensko stalno gledališče Trst, triestinità, West European playwrights, cultural junctures

\section{Zgodovinski oris}

\section{Do leta 1945 so v slovenski zgodovini zapisana tri narodna gledališča:} Ljubljana (1867, 1892, 1918), ${ }^{\mathrm{I}}$ Trst (1902) in Maribor (1909). Zgodovina slo-

1 Leta 1867 je bilo ustanovljeno Dramatično društvo, kar štejemo za začetke delovanja slovenskega narodnega gledališča v Ljubljani. Sicer je bilo (z uradnim nazivom) Narodno gledališče v Ljubljani ustanovljeno leta 1918, pred njim (od 1892) deluje kot Deželno gledališče, v letu 1919 se preimenuje v Kraljevsko slovensko gledališče Ljubljana in od 1920 ponovno v Narodno gledališče v Ljubljani. 
venske gledališke dejavnosti v Trstu se začne po revolucionarnem letu 1848, ko je bilo ustanovljeno Slavljansko društvo, 2. junija 1850 so uprizorili komedijo češkega avtorja Štêpáneka Tat v mlinu ali Slovenec in Nemec (Kravos 2015, 9), leta 1861 je bila odprta čitalnica, Bogomila Kravos posebej izpostavi tudi gostovanje Deželnega gledališča iz Ljubljane, ki je januarja $1880 \mathrm{v}$ gledališču La Fenice odigralo komedijo Josipa Ogrinca $V$ Ljubljano jo daj$m o$ !, kar je poglabljalo stike med (pol)profesionalnimi igralci iz Ljubljane in amaterskimi igralci iz Trsta. Močna slovenska skupnost $\mathrm{v}$ Trstu in želja po profesionalizaciji gledališke dejavnosti sta privedli do ustanovitve Dramatičnega društva v Trstu 8. marca 1902. Ta institucija naj bi (po)skrbela za postopno profesionalizacijo in zagotovitev lastne gledališke dvorane. Društvo je $\mathrm{z}$ aktivnostmi $\mathrm{v}$ dveh letih poskrbelo za izgradnjo Narodnega doma, ki je bil, po načrtih arhitekta Maksa Fabianija, končan leta 1904. Slavnostno odprtje je bilo 15. decembra 1904, prva gledališka premiera pa 8. januarja 1905 z Rokovnjači Frana Govekarja in Josipa Jurčiča. Stalni igralski ansambel je bil ustanovljen 1. junija 1907 in Trst je dobil »redno slovensko gledališče na umetniški podlagi« (Moravec 1992, 1186), umetniško vodstvo je prevzel Anton Verovšek. Tržaško gledališče je z velikim uspehom delovalo tudi po prvi svetovni vojni, vodje so bili pomembna imena slovenskega gledališča, poleg Verovška tudi Avgusta Danilova in Milan Skrbinšek. ${ }^{2}$ Če presojamo profesionalno gledališko dejavnost v Trstu do leta 1920, nam zadošča izsek iz kritike Frana Albrehta, ki je ob gostovanju Satana $v$ ženski (Karl Schönherr) v Ljubljani zapisal, da je drama, »ki so jo uprizorili tržaški gostje: Skrbinšek, Martinčević in Skrbinškova [...] po svoji umetniški višini dosegla najboljše, kar nam je nudila letošnja sezona" (Skrbinšek 1963, 105). V prvih dvajsetih letih profesionalnega delovanja je bilo uprizorjenih 245 dramskih besedil in 19 oper, operet in baletov. Zgolj za oris trdoživosti in želje po ustvarjanju v slovenskem jeziku naj služi podatek, da v letih od 1918 do 1920 gledališče uprizori kar 54 del; in to v času, ko je bila slovenska skupnost že pod italijansko oblastjo in so se že dogajali prvi pritiski, ter navkljub slabemu finančnemu položaju po koncu prve svetovne vojne. Med njimi je bila tudi krstna uprizoritev Hlapcev Ivana Cankarja, ki v Ljubljani niso imeli možnosti uprizoritve. Posebej je treba poudariti, da je bilo na odru tržaškega gledališča pod Skrbinškovim umetniškim vodstvom v letih 1919 in 1920 kar sedem uprizoritev Ivana Cankarja: Kralj

2 Iz tega obdobja gotovo najpomembnejše mesto zavzemajo uprizoritve dramatike Ivana Cankarja in evropskih klasikov Augusta Strindberga, Antona P. Čehova, Henrika Ibsena, Friedricha Schillerja, Williama Shakespeara, J. B. P. Molièra ... 
na Betajnovi (11. 1. 1919), Lepa Vida (10. 4. 1919), Za narodov blagor (16. 4. 1919 in 4. 3. 1920), Pohujšanje v dolini Šentflorjanski (17. 5. 1919), Hlapci (31. 5. 1919 in 8. 2. 1920), v tej seriji uprizoritev nista dočakali drami Jakob Ruda in Romantične duše. Tržaško gledališče je fenomen ${ }^{3}$ samo po sebi, presenetljiv pa je tudi podatek, da so kar dvakrat poskušali uprizoriti celoten Cankarjev dramski opus. ${ }^{4}$ Prvo obdobje tržaškega gledališča merimo od ustanovitve Dramatičnega društva do požiga Narodnega doma. Repertoar slovenskih gledališč beleži podatek, da je bila prva uprizoritev po ustanovitvi Dramatičnega društva 27. aprila 1902 spevoigra Čevljar - Baron Rudolfa Hahna, zadnja uprizoritev v Narodnem domu pred fašističnim požigom 13. 7. 1920 pa Veleja Antona Novačana (29. 4. 1920).

\section{Obča zgodovina po 1945 in delovanje SSG Trst v povojnem obdobju}

Glavno osišče obdobja po drugi svetovni vojni na Tržaškem zaznamuje nastanek in reševanje t. i. tržaškega vprašanja. Kot zapišeta Dušan Nećak in Božo Repe, je Trst zaradi svojega strateškega položaja postal krizno žarišče. Ta strateški položaj Trsta je tudi razlog za razvoj mesta pod Habsburžani in pozneje edini stik z odprtim morjem Avstro-Ogrske. Po vojni postane Trst najjužnejša točka železne zavese. Želja jugoslovanskih oblasti je, da se tudi Trst z zaledjem priključi Jugoslaviji, kot je bilo to s preostalimi ozemlji, ki so bila pod italijansko okupacijo že od določitve rapalske meje dalje.

Gledališče, ki deluje na meji, predstavlja nacionalno kulturo države (naroda), a v drugi državi. Podobni fenomeni se ustvarjajo $\mathrm{v}$ metropolah $\mathrm{z}$ močno manjšinsko skupnostjo, v Bratislavi npr. deluje t. i. madžarsko gledališče Ifju Szivek.

Prvič v Skrbinškovem času neuspešno, a drugič uspešno, ko so v letih od 1986 do 1992 uprizorili celoten opus, za kar sta poskrbela upravnik Filibert Benedetič (na funkciji: 1976-87) in Miroslav Košuta (1987-99). Povezava z Ivanom Cankarjem sega v čas po državnozborskih volitvah (1907), ko je neuspešno kandidiral za poslanca socialdemokratske stranke. Svoje politično delovanje je nadaljeval v obliki predavanj in pisnih razprav, v sklopu katerih je večkrat uspešno gostoval v Trstu.

Vzpon fašizma je povzročil velike pritiske na slovensko skupnost, ki je po določitvi rapalske meje pripadla Republiki Italiji. Iredentistična miselnost je izrivala vse, kar je bilo neitalijanskega. Narodno nasprotovanje je eskaliralo s požigom Narodnega doma. V njem je zgorela knjižnica, sedež Glasbene matice, sedež sokolskega, dijaškega in planinskega društva. Uničeni so bili hotel Balkan z restavracijami in kavarno, slovenska kreditna banka in sedež delavsko-podpornega društva, torej vse pomembnejše organizacije, ki so združevale tržaške Slovence. Zapišemo lahko, da je bil nasilno uničen veličasten simbol moči slovenske kulture. Požig je skupaj z vzponom fašizma pomenil konec gledališke dejavnosti v slovenskem jeziku do konca druge svetovne vojne. (Glej: Kacin Wohinz in Pirjevec 200o) 
Zavezniki so v mirovni pogodbi z Italijo (podpisana 10. 2. 1947) ustanovili Svobodno tržaško ozemlje (STO) in ga razdelili na dve coni. Cona A je obsegala Trst $\mathrm{z}$ okolico in je bila pod nadzorom zavezniških sil, cona $\mathrm{B}$ pa koprski in bujski okraj, bila pa je pod jugoslovansko oblastjo (Nećak, Repe 2003, 197). Po zaostritvi odnosov med zavezniki, aferi informbiro, je konflikt eskaliral skoraj do vojaških spopadov; v pogajanjih je bilo nato določeno (1954), da se cona A priključi Italiji, cona B pa Jugoslaviji. Treba je tudi premisliti pojem prepustnosti oz. odprtosti te meje, ki je bila meja med zahodom in vzhodom, socializmom in kapitalizmom.

Italija je imela razmejitveno črto le za demarkacijsko črto tj. za začasno ureditev. Šele leta 1975 je bilo to vprašanje rešeno z Osimskimi sporazumi. Dotedanja »demarkacijska črta« je bila spremenjena v pravo mejo med državama, ki pa je bila že mnogo pred tem ena najbolj odprtih mej v Evropi, sploh pa med državama z različno družbeno ureditvijo. (Nećak, Repe 2003, 198)

Od leta 1945 se gledališka dejavnost v Trstu spet obudi in gledališče znova deluje kot poklicno in repertoarno. Tako so v začetku decembra 1945 v gledališču Fenice uprizorili priredbo Ferda Delaka Jernejeva pravica, ki je nastala po povesti Hlapec Jernej in njegova pravica Ivana Cankarja, nato Desetega brata Josipa Jurčiča in komedijo Scampolo Daria Niccodemija. Kmalu so stekli tudi pogovori o graditvi novega kulturnega doma, ki bi nadomestil uničeni Narodni dom; ustanovljen je bil Odbor za gradnjo kulturnega doma, 21. 7. 1957 so položili temeljni kamen, odprtje je bilo 5 . 12. 1964. Takrat se je začel tudi postopek za pridobitev statusa institucije - javne ustanove, ki ga je italijansko Ministrstvo za turizem in prireditve podelilo leta 1977 , in tako SSG Trst postane javnopravna gledališka ustanova. Tržaško gledališče je takrat eno izmed osmih italijanskih gledališč, ki ima naziv teatro stabile (stalno gledališče). Po dekretu iz leta 2007 Republika Italija priznava status stalnih gledališč sedemnajstim gledališkim hišam, tudi dvema tržaškima: Slovenskemu stalnemu gledališču Trst in Stalnemu gledališču Furlanije - Julijske krajine Trst (E. A. Teatro Stabile del Friuli Venezia Giulia). ${ }^{6}$ 


\section{Uprizoritve zahodnoevropskih in ameriških avtorjev}

\section{v Slovenskem stalnem gledališču Trst v prvih desetletjih}

po drugi svetovni vojni

Pregled uprizoritev zahodnoevropskih in ameriških dramatikov v SSG Trst v obdobju po drugi svetovni vojni nam razkriva duhovno podobo gledališča kot institucije. Izbrano časovno okno nudi nekaj materiala za analizo, ki bo predstavila umetniško vodenje glavne slovenske kulturne ustanove v Italiji. Da bi poglobili vedenje in razširili pogled, bomo v nadaljevanju za vzpostavitev konteksta delovanje SSG Trst primerjali s sočasno produkcijo SNG Drame Ljubljana. Režiserji, ki delujejo v Trstu ali prihajajo iz Jugoslavije, so pomembna imena slovenske gledališke zgodovine: Modest Sancin, Ferdo Delak, Milan Košič, Jože Tiran in Jože Babič, ki je tržaško gledališče povzdignil na raven "primerljivo z drugimi slovenskimi profesionalnimi gledališči, kar se je še zlasti kazalo pri tako imenovani kritiški recepciji« (Vevar 1998, 64). Posebej viden umetniški razvoj gledališča se zgodi po izgradnji novega kulturnega doma leta 1964, ko se poveča število nagrad, ki jih maloštevilen ansambel prejema na tekmovalnih festivalih. V tem obdobju prihajajo v Trst režirat tudi pomembni režiserji sodobnega slovenskega gledališča: Dušan Jovanović, Mile Korun, Andrej Hieng, Dušan Mlakar, Mario Uršič, Zvone Šedlbauer in drugi.

Pregled uprizoritev nam pove, da $\mathrm{v}$ času po vojni ni posebej naraslo uprizarjanje sodobnih slovenskih dramskih besedil, razloge za to bo treba iskati v neprijazni družbenopolitični klimi, še posebej po pripojitvi dveh con različnima državama. Vodstvo gledališča kljub temu vztrajno išče stik z matico prek uprizarjanja slovenskih dramskih besedil. Najprej s partizansko dramatiko (agitkami), ki jo predstavljajo Andante patetico Vitomila Zupana (7. 12. 1945, r. Jože Tiran), Raztrganci Mateja Bora (17. 2. 1946, r. Just Košuta), sledile so prve uprizoritve Ivana Cankarja (otvoritvena predstava Jernejeva pravica, nato Kralj na Betajnovi, Hlapci ...), politična drama Mire Mihelič Ogenj in pepel (3. 6. 1949, r. Milan Košič). Od slovenskih del so sicer na repertoarju tudi dela Antona T. Linharta, Miška Kranjca, Frana S. Finžgarja, Herberta Grüna, Bratka Krefta in drugih. Večinski del repertoarja zavzemajo lahkotnejši teksti in otroške ali mladinske igre.

Prehod $\mathrm{k}$ sodobnejšim dramskim poetikam se zgodi šele $\mathrm{z}$ uprizoritvijo Odločitve Jožeta Javorška (v soavtorstvu z Jožetom Tiranom), ki dogajanje postavi v obdobje po prvi svetovni vojni, ko Trst po odločitvi zaveznikov pade v italijanske roke. Drama ima za središče odnos med fašizmom in 
Slovenci, ki živijo v Italiji. ${ }^{7}$ Druga Javorškova igra, uprizorjena v Trstu, komedija Manevri (12. 11. 1960, r. Jože Babič), govori o odsluženih vojaških rezervistih, ki se odločijo uprizoriti Levstikovega Martina Krpana. Ko se lotijo uprizoritve, zgodbo nadgrajujejo in jo dodajajo, kar le stopnjuje komični učinek in tudi trpko poanto, ki bi jo lahko tržaška publika razumela zelo aktualno, kot lasanje slovenskega Krpana z velikim tujim Brdavsom.

Do sredine šestdesetih let sta to edini novonastali sodobni slovenski dramski besedili (če odštejemo agitke in drame socialnega realizma), ki doživita uprizoritev na odru SSG Trst. Večji premik se zgodi po izgradnji nove dvorane, ko uprizorijo tudi za ljubljanske razmere aktualne drame: Dialogi (Primož Kozak, 12. 1. 1965, r. Jože Babič), Študentska soba (Igor Torkar, 12. 1. 1965, r. Jože Babič) in Kongres (Primož Kozak, 19. 4. 1965, r. Jože Babič). Gre za dramska besedila, ki so že ob svojih krstnih uprizoritvah naletela na velik odziv tako na strani oblasti in kritike kot tudi gledalcev, saj se je v njih kazala učinkovita kritika aktualne družbene stvarnosti. Izmed slovenskih tržaških avtorjev, ${ }^{8} \mathrm{ki}$ jih uprizarjajo v tem obdobju, naštejmo uprizoritve Šagra (Rade Pregarc, 20. 10. 1956, r. Jože Babič), Pisma Julije de Laespinase (Mira Sardoč, 29. 4. 1966, r. Branko Gombač), Ne vedno kakor lastovke (Filibert Benedetič, 23. 2. 1967, r. Jože Babič), Anarhist (Jaka Štoka, 3. 11. 1967, r. Jože Babič) in Moč uniforme (Jaka Štoka, 22. 11. 1969, r. Mario Uršič). Najpogosteje uprizarjan slovenski tržaški avtor je bil Josip Tavčar: Prihodnjo nedeljo (9. 11. 1957, r. Jože Babič), Pekel je vendar pekel (4. 3. 1959, r. Jože Babič), Ogledalo (4. 3. 1959, r. Jože Babič), Nicky - zlati deček (21. 11. 1952, r. Jože Babič), Zeh pred smrtjo (28. 1. 1962, r. Adrijan Rustja), $V$ Honolulu (11. 5. 1963, r. Adrijan Rustja), Mrtvi kanarček (4. 3. 1966, r. Jože Babič), Red mora biti (9. 1. 1969, r. Žarko Petan). Kot posebnosti tega časa ostajata tudi uprizoritev Škofjeloškega pasijona (p. Romuald Marušič, 11. 4. 1965) v režiji Mirka Mahniča in ugledališčeni izbor del tržaških pesnikov in pisateljev, ki se je pod naslovom Rusi most zgodil 10. 2. 1968 v režiji Jožeta Babiča.

$7 \quad$ V prvem dejanju spremljamo fašistične tehnike raznarodovanja, v drugem dejanju pa nas avtor postavi v drugo svetovno vojno, ko se osrednja junaka (Tržačana) Just in Branko odpravita v partizane in se borita proti Italijanom; ko je vojne konec, se kot edina iz svojih družin vrneta v Trst, ki pa je (spet) italijanski. Spoznata, da je bila njuna borba nesmiselna, a ko stopita v hišo, ju v njej pričakajo vsi »njuni« pokojni, kar je očitno znamenje, da borbe za slovenski Trst še ni konec. (Glej: Schmidt Snoj 2010, 444-449)

8 Terminološko razlikovanje med slovenskimi tržaškimi avtorji in italijanskimi tržaškimi avtorji je potrebno zaradi italijanskega pojma »letteratura triestina«, ki označuje zgolj literaturo v italijanskem jeziku. (Glej: Toroš 2014) 
Zahodnoevropske dramatike, ki so bili uprizorjeni na odru Slovenskega stalnega gledališča $\mathrm{v}$ Trstu, lahko razdelimo $\mathrm{v}$ tri glavne skupine: avtorji zgodovinske klasike (t. i. železni repertoar: Shakespeare, Molière, Schiller ...), lahkih dramskih žanrov (John B. Priestley, Neil Simon, George B. Shaw, Agatha Christie, Albert Hackett, John Steinbeck, Lillian Hellman ...) in predstavniki (takrat) sodobne dramske pisave (Dario Fo, Eugene Ionesco, Jean-Paul Sartre, Samuel Beckett, Ugo Betti, John Knittel ...). SSG Trst je vodilno slovensko gledališče pri uprizarjanju del italijanskih avtorjev: Dario Fo, Luigi Pirandello, Ugo Betti, Aldo de Benedetti, Nicola Manzari, Renato Lelli ... ' Ameriški avtorji so bili v SSG Trst redkeje uprizarjani, med uprizoritvami najdemo pomembna avtorja, kot sta Arthur Miller in Eugene O'Neill. Millerjevo najbolj znano dramo Smrt trgovskega potnika so premierno odigrali 9. 4. 1963 v režiji Slavka Jana, Eugene O'Neill pa je bil uprizorjen dvakrat, prvič z besedilom Ana Christie (29. 4. 1946, r. Milan Košič), drugič pa z melodramo z ameriškega podeželja Strast pod bresti (19. 10. 1957, r. Jože Babič). ${ }^{10}$

Našteti podatki dobijo smisel, ko jih postavimo v kontekst oz. jih primerjamo s podobno situacijo. Glede na zapleteno politično, socialno, umetniško in finančno situacijo je težko najti primerljivo gledališko hišo, da bi brez težave argumentirali vse morebitne vzporednice ali razlike. SSG Trst že s svojo zgodovinsko dediščino odločilno odstopa od preostalih slovenskih gledaliških hiš. A ker je po tradiciji (ne več formalno) tržaško gledališče eno izmed treh slovenskih nacionalnih gledališč in je od druge svetovne vojne vodilna gledališka ustanova za Slovence v Italiji, je razumljivo, da bomo za primerjavo izbrali ljubljansko SNG Dramo, ki po tradiciji zaseda podoben položaj.

Čas po drugi svetovni vojni je zaradi političnih razmer $\mathrm{v}$ nedemokratičnem sistemu (kar je ena izmed temeljnih razlik, ko primerjamo tržaško gledališče $\mathrm{z}$ ljubljanskim) za gledališke profesionalce pomenil velik izziv pri iskanju poti do uprizoritev avtorjev kapitalističnega Zahoda. Situacija se delno spremeni ob postopnejši liberalizaciji države in postopnemu odpiranju na Zahod. Če smo okvirno označili pomembnejše avtorje na odru SSG Trst, poglejmo še v SNG Dramo, ki je reprezentativen primer, saj se zaradi kvalitativno močne produkcije $\mathrm{v}$ razmeroma kratkem obdob-

9 Netržaški italijanski avtorji. Za takšne repertoarne odločitve je najverjetneje vzrok zgodovinska nenaklonjenost italijanskim tržaškim avtorjem, kar bomo pozneje prikazali na primeru Fulvia Tomizze. bo $\mathrm{v}$ pomoč pri kronološki umestitvi uprizoritev. 
ju na repertoarju pojavi večja količina zahtevnejših besedil; tako vsebinsko kot uprizoritveno. Na repertoarju so: Arthur Miller, Tennesee Williams, Eugene O'Neill, Jean Anouilh, Jean-Paul Sartre, Albert Camus, John Osborne, Bertolt Brecht, Friedrich Dürrenmatt in Max Frisch. Čeprav v repertoarju osrednje gledališke hiše $v$ petdesetih letih najdemo še druge zahodne avtorje, kot so Anna Christie, Arnaud d'Usseau, Fritz Hochwälder, Lillian Hellman, Delaney Shelagh idr., je osišče premisleka treba ostriti na primerih, ki so izstopali že v kapitalističnem svetu in so zato za socialistično državo ter misel pomenili pomemben precedens. Izbor besedil je utemeljen predvsem na podlagi prelomnosti dram $\mathrm{v}$ globalnem smislu, izstopajoči kvaliteti nove dramske pisave in razmeroma hitri uprizoritvi na slovenskih odrih glede na nastanek. Ljubljanska Drama po svoji tradicionalni vlogi skrbi za uprizarjanje slovenskih besedil, a je poleg te naloge zagotavljala tudi seznanjanje slovenskega občinstva $\mathrm{z}$ aktualnimi dramski$\mathrm{mi}$ besedili iz tujine. Skrb za to so prevzeli ravnatelji in dramaturgi, ki so (včasih bolj, včasih manj) uspešno iskali stik s sodobnimi dramskimi pisci in poskušali omogočiti uprizoritve na odru narodnega gledališča.

Primerjavo izbranih uprizoritev obeh gledališč nam izrisuje več razlik kot podobnosti. V repertoarju SNG Drame velik delež zavzemajo ameriški avtorji (Arthur Miller, Tennesee Williams, Edward Albee in starejši Eugene O'Neill), medtem ko jih v SSG Trst skorajda ne zasledimo. Izjema je že omenjena uprizoritev najuspešnejšega Millerjevega dela Smrt trgovskega potnika. Velik razkorak se kaže tudi v uprizarjanju dramatike z nemško govorečega območja, kjer delujejo pomembni moderni klasiki (Friedrich Dürrenmatt, Max Frisch, Bertolt Brecht ...) in so stalnica na ljubljanskem odru, a jih v Trstu ne uprizarjajo. ${ }^{\text {II }}$ Prav tako slovenska tržaška publika ne spozna francoskega eksistencializma, saj je od te generacije uprizorjeno zgolj besedilo Jeana-Paula Sartra Umazane roke, del Alberta Camusa sploh ne zasledimo. Na tem mestu je treba poudariti, da avtorji, kot so John Osborne, Albert Camus in Bertolt Brecht, še niso bili uprizorjeni v SSG Trst.

$\mathrm{Na}$ drugi strani se izrisuje pomembno poslanstvo pri uprizarjanju italijanskih avtorjev, ki so stalnica v tržaškem repertoarju, a jih SNG Drama uprizarja le redko (še najpogostejši je Pirandello). Ima pa slovenski tržaški repertoar nekaj poudarkov, ki ga profilirajo kot gledališče, ki

11 To dejstvo lahko delno upravičimo z izgovorom, da so bili ti avtorji uprizarjani v tržaškem gledališču Rosseti. Temu razkoraku se bomo posvetili v nadaljevanju razprave. 
išče nove zgodbe manj izpostavljenih zahodnih avtorjev. SSG Trst je, denimo, (1. 1954) uprizorilo dramo Mladost pred sodiščem nizozemskega avtorja Hansa Tiemeyerja, ki je bila istega leta uprizorjena v še štirih drugih slovenskih gledališčih (Celje, Koper, Ptuj, Kranj). Med redke posebnosti štejemo tudi uprizoritev finske avtorice (estonskega izvora) Helle Wuolijoki Žene na Niskavuoriju (21. 2. 1953, r. Jože Babič), ki je bila pred tem uprizorjena v SNG Drami Ljubljana (1938) in SNG Drami Maribor (1946). Med podobnimi primeri navedimo še besedilo Jajce, ki ga je Félicien Maceau napisal leta 1957, premiera v Trstu pa je bila 4. 5. 1968 (r. Adrijan Rustja).

Temeljne razlike med obema gledališkima hišama je treba iskati tudi v posebnem položaju SSG Trst, ki na repertoar pogosto uvršča slovenska dela, tudi s poudarkom na slovenskih tržaških avtorjih, vse v skladu z zapisom Draga Štoke:

Mnogo kulturnih organizacij zvesto ponazarja ideologijo tistih, ki so v njenih vrstah, večji del pa je nastal v obrambo etnično-jezikovnih potreb in deluje na kulturnem področju manjšine s poglavitnim namenom, da ohrani etnične, jezikovne in narodnostne značilnosti slovenske manjšine. (Štoka 1975, 527)

Ta naloga je še vedno ena od poglavitnih v delovanju SSG Trst in tudi našo temo je treba obravnavati (tudi) skozi ta aspekt. Nedvomno dejstvo je, da prvotna naloga gledališča ni bila razvijanje gledališkega izraza ali dramske umetnosti, temveč ohranjanje živega (slovenskega) odrskega jezika in kulturne institucionalne prisotnosti v mestu. To je prvi izmed odgovorov na vprašanje, zakaj se repertoar tržaškega gledališča ne razvija v smeri zahodnih tokov, ampak ostaja pripet na lokalne vzorce. Veliko vlogo pri umetniški usmeritvi ima politični sistem države, v kateri deluje gledališče. Tržaško gledališče, ki je bilo delno financirano tudi iz Jugoslavije, deluje v zahodni demokraciji, italijanska republika $\mathrm{z}$ demokratično izvoljenim vodstvom (državnim, pokrajinskim, deželnim) omogoča svobodo izražanja. Na drugi strani meje mora osrednje slovensko gledališče SNG Drama Ljubljana delovati v omejenem okolju enopartijskega sistema ter se (posledično) ves čas spopadati s politiko in režimom pri iskanju stikov z zahodnimi estetikami in novostmi. V Trst prihajajo različni profili umetnikov iz Jugoslavije in na ta način se slovensko tržaško gledališče vedno obrača stran od zahodnih trendov, ki jih srečamo v drugih italijanskih gledališčih tega časa, ter tako postaja gledališče, ki deluje na Zahodu (v kapitalizmu), a je zaradi močnih stikov prek meje močno orientirano k Vzhodu 
(socializmu). A položaja ne smemo prehitro posplošiti na celotno produkcijo SSG Trst tega obdobja. Posebnost, ki najbolj dokazuje pomembnost tržaškega gledališča za celoten slovenski prostor in tudi njegovo odprtost $\mathrm{v}$ svet, je slovenska praizvedba absurdne antidrame Čakajoč Godota Samuela Becketta (r. Branko Gombač), ki se je zgodila 24. 2. 1966, dve leti pred premiero istega besedila v SNG Drami Ljubljana. V Trstu so uspeli med prvimi slovenskemu občinstvu predstaviti tudi Eugèna Ionesca, saj so njegove Stole v režiji Balbine Baranovič uprizorili 28. 12. 1960, dve leti po prvih uprizoritvah Ionesca na Odru 57 (Učna ura, 31. 3. 1985, r. Žarko Petan in Plešasta pevka, 8. 4. 1958, r. Janez Čuk). Te uprizoritve so pomembne zaradi iskanja novih uprizoritvenih možnosti, pa tudi kot tihi protest proti stanju v družbi, saj avtorji drame absurda sami po sebi kritizirajo nesmiselnost povojne evropske družbe. Tržaško gledališče se tako priključuje svojim sodobnikom in (kot že omenjeno) nosi velike zasluge tudi pri seznanjanju z vodilnimi italijanskimi dramatiki.

$\mathrm{Na}$ tem mestu bi na kratko predstavili še glavne poudarke gledališča Rosseti iz Trsta, ki v istem obdobju uprizarja pomembnejše zahodnoevropske avtorje. Rosseti so ustanovili leta 1954 in je eno od najstarejših stalnih gledališč (teatro stabile) v Italiji. V času od ustanovitve do leta 1970 njihov program sestavljajo po večini italijanski avtorji, italijanska klasika (Goldoni, Gozzi, Gigli ...), rimska dramatika (Plavt ...), približno četrtino repertoarja pa zasedajo uprizoritve zahodnoevropskih in ameriških dramatikov, med katerimi najbolj izstopajo: Jean Anouilh, Friedrich Dürrenmatt, Eugene Ionesco, John Osborne, Jean Genet ... ${ }^{12}$ Uprizorijo tudi veliko Brechtovih iger in lirike, posebej moramo izpostaviti dve uprizoritvi Tržačana Fulvia Tomizze Vera Verk (1963) in La storia di Bertoldo (ali La Fiaba di Bertoldo, 1968), saj je Tomizza v slovenskem gledališču prezrt, edino njegovo dramsko delo, ki doživi uprizoritev, je drama Idealist, dramatizacija Martina Kačurja (Ivan Cankar), uprizorjena 12. 9. 1985 v Primorskem dramskem gledališču Nova Gorica (režiser Jože Babič). Zgodovinski razlog neu-

12 Jean Anouilh: Leocardia (1955), Tennesee Willimas: Steklena menežarija (1956), Federico G. Lorca: Lepa čevljarka (1956), Eugene O'Neill: Dolgega dne potovanje v noč (1957), Eugene Ionesco: Jaques ali podrejenost (1958), Samuel Beckett: Čakajoč Godota (1959 in 1961), Učna ura (1961), Friedrich Dürrenmatt: Zakon gospoda Mississippija (1962), John Osborne: A Subject of Scandal and Concern (1963), Albert Camus: Pravični ljudje (1965), Osborne: Luther (1967), Jean Genet: Poostreni nadzor (1968), Ionesco: Morilec (1968) in enodejanke, Jean Cocteau: Ti strašni starši (1969), Edward Albee: Vrt (1969), Jean-Paul Sartre: Nekrassov (1970), Fernando Arrabal: Le cimetière des voitures (1970) in Ferdinand Bruckner: Bolezen mladosti (1970). V oklepaju navajamo letnico uprizoritve. 
prizarjanja Tomizze je lahko posledica njegove življenjske zgodbe, saj je bil kot Istran pregnan iz Jugoslavije, to doživlja kot travmo in po vojni živi v Trstu, kar je tudi pogosta tema v njegovi literaturi.

Glede na našteta besedila lahko sklepamo tudi, da se je v tržaškem prostoru v obdobju po drugi svetovni vojni uprizarjalo sodobna dela evropske in ameriške dramatike, le da je pobudo prevzelo novoustanovljeno gledališče Rosseti. Zato lahko postavimo tezo, da je bil repertoar SSG Trst bolj specifičen ravno zaradi možnosti izbire in večje ponudbe v mestu. Podoben primer srečamo pri razmerjih med ljubljanskimi gledališči, kjer je Mestno gledališče ljubljansko v primerjavi z SNG Dramo uprizarjalo manj prelomna besedila in se posvečalo slovenskim avtorjem in lažjim žanrom. Slovensko tržaško gledališče spada med manjša gledališča, temu ustrezno je tudi financiranje, zato si je svoj umetniški izraz in prostor moralo iskati na način, ki ni vključeval večjih zasedb in spektakelske scenografije. Zaradi specifike občinstva, ki je gledališče dojemalo kot prostor slovenske besede, so bile uprizoritve včasih prikrajšane za nove režijsko-igralske prijeme. Že omenjena majhnost gledališča te vrste nehote sili k drugačnim repertoarnim odločitvam, saj ne (z)morejo konkurirati večjim gledališkim hišam po raznovrstnosti repertoarja in to rešujejo $z$ uprizarjanjem manj znanih in izvirnih dramskih besedil.

\section{Temeljne ugotovitve in zaključek}

$\mathrm{V}$ razpravi smo želeli predstaviti gledališko dejavnost na Tržaškem in jo umestiti v čas in prostor. Primerjava z ljubljansko SNG Dramo in gledališčem Rosseti nam kaže, kakšen je (bil) položaj Slovenskega stalnega gledališča Trst. Glavni poudarki te raziskave so dejstva, da na razvoj gledališke institucije vpliva politično okolje (režim) države, v kateri deluje, in vizija posameznih umetniških vodij. Toliko bolj specifična je torej podoba slovenskega gledališča v Trstu, ki je svojo dejavnost moralo opredeliti najprej $\mathrm{z}$ nacionalnim poslanstvom, nato kot temeljna ustanova živega slovenskega jezika v Italiji in kot gledališče samo, ki se kot umetniška disciplina nikoli ne preneha razvijati in iskati novih poti do sodobnejšega izraza. Naša razprava dokazuje pomembnost delovanja tržaškega gledališča za celoten slovenski prostor, ne zgolj za slovensko skupnost v Italiji. Uprizoritve zahodnoevropskih avtorjev na odru SSG Trst, s posebnim fokusom na sodobne italijanske dramatike, so bile dobrodošla obogatitev (sicer) proslovensko (celo projugoslovansko) usmerjenih repertoarjev. 
Slovensko stalno gledališče $\mathrm{v}$ Trstu, ${ }^{\mathrm{I}}$ še posebej njegovo novejšo zgodovino, je podrobneje popisala in opredelila vodilna raziskovalka Bogomila Kravos, naša raziskava pa to dejavnost postavlja v kontekst celotnega slovenskega gledališkega prostora. Slovensko gledališče v Trstu je eno od treh najstarejših slovenskih (narodnih) gledališč in zato pomembno zaradi svojega delovanja $\mathrm{v}$ večjezičnem prostoru, obujanja in ohranjanja (pa tudi preizpraševanja) nacionalne identitete, iskanja nove - tržaške - dramatike in zagotavljanja prisotnosti gledališke produkcije v slovenskem jeziku. Prav sobivanje več različnih kultur, ki imajo svojo zgodovinsko vlogo pri sooblikovanju podobe Trsta, je pomembno vprašanje tudi pri delovanju gledališča. Slovenci v Italiji živijo v treh pokrajinah dežele Furlanije - Julijske krajine: na Tržaškem, Goriškem in Videmskem, slovenska naselja so zgodovinsko prisotna v 36 občinah vzdolž obmejnega pasu slovensko-italijanske in delno italijansko-avstrijske meje (Mikolič, Pertot 2006, 19). To je tudi področje, ki ga neposredno gledališko pokriva SSG Trst. Prisotnost slovenskega gledališkega izraza v Italiji tako dobiva več funkcij: sobivanje med različnimi kulturami, njihovo povezovanje, skrb za slovenski jezik in gledališko izobraževanje, odpiranje vprašanja vloge in položaja narodne zavesti ob gostovanjih po krajih, kjer živijo Slovenci ... Uprizoritve sodobne evropske in ameriške dramatike so dokaz odprtosti institucije, (o)vrednotenja umetniških tokov ter (kot ena od bolj konvencionalnih dejavnosti gledališča) družbene kritike, izražene skozi besede (in zgodbe) tujca ali oddaljenega subjekta. $V$ prihodnosti bo treba raziskati še uprizarjanje slovenskih tržaških avtorjev v gledališču Rosseti (ali drugih italijanskih gledališčih) ter uprizoritve italijanskih tržaških avtorjev na odru SSG Trst, predvidevamo lahko, da je bilo tovrstnih uprizoritev malo oz. nič. Gledališče na stičišču kultur je torej lahko kraj spajanja, mešanja ali razdvajanja različnih uprizoritvenih in dramskih poetik, ki so ne nazadnje vedno pogojene s političnim ali mednacionalnim stanjem $\mathrm{v}$ okolju, kjer gledališče deluje.

\section{Viri}

Repertoar slovenskih gledališč (izdaja Slovenski gledališki inštitut), dostopen na <http://repertoar.sigledal.org>. (Dostop 16. 9. 2016.)

13 Slovensko stalno gledališče v Trstu, kot že zapisano, od leta 1945 deluje kot poklicno repertoarno gledališče, uraden status mu priznava tudi Republika Italija, ki ga je uvrstila med redka gledališča v državi s priznanim statusom stabile, stalnim ansamblom in državnim financiranjem. 


\section{Literatura}

Jeri, Janko (et al.), ur. 1975. Slovenci v Italiji po drugi svetovni vojni. Ljubljana: Cankarjeva založba.

Kacin Wohinz, Milica, in Pirjevec, Jože. 20oo. Zgodovina Slovencev v Italiji 1866-20oo. Ljubljana: Nova revija.

Kravos, Bogomila. 2001. Slovensko gledališče v Trstu (1945-1965). Ljubljana: Slovenski gledališki muzej.

Kravos, Bogomila. 2015. Un teatro per la città. Trst: Slovenski raziskovalni inštitut SLORI.

Mikolič, Vesna; Pertot, Susanna, in Zudič Antonič, Nives. 2006. Med kulturami in jeziki. Koper: Založba Annales.

Moravec, Dušan. 1992. »Tržaško meddobje Antona Verovška«. Sodobnost 12: 1185-1194.

Nećak, Dušan, in Repe, Božo. 2003. Oris sodobne obče in slovenske zgodovine. Ljubljana: Filozofska fakulteta, Oddelek za zgodovino.

Pertot, Susanna, in Kosic, Marianna, 2014. Jeziki in identitete v precepu: mišljenje, govor in predstave o identiteti pri treh generacijah maturantov šol s slovenskim učnim jezikom v Italiji. Trst: Slovenski raziskovalni inštitut SLORI.

Schmidt Snoj, Malina. 2010. Tokovi slovenske dramatike. Ljubljana: Slovenski gledališki muzej.

Skrbinšek, Milan. 1963. Gledališki mozaik. Ljubljana: Knjižnica Mestnega gledališča ljubljanskega.

Štoka, Drago. 1975. »Slovenci v Italiji«. V Slovenci v Italiji po drugi svetovni vojni, ur. Janko Jeri. Ljubljana: Cankarjeva založba.

Toroš, Ana. 2014. »Triestinità and tržaškost«. Slovene Studies 36 (1): 39-54.

Troha, Gašper. 2015. Ujetniki svobode. Maribor: Aristej.

Vevar, Štefan. 1998. Slovenska gledališka pot. Ljubljana: Državna založba Slovenije. 


\section{Izkušnja migracije in integracije $\mathrm{v}$ slovenski prostor $\mathrm{v}$ avtobiografskih literarnih delih Stanislave Chrobakove Repar in Erice Johnson Debeljak}

Megi Rožič

Fakulteta za humanistiko, Univerza v Novi Gorici Faculty of Humanities, University in Nova Gorica megi.rozic1@gmail.com

Prispevek preko literarne analize avtobiografskih literarnih del: Slovenka na kvadrat (2009) Stanislave Chrobakove Repar in Prepovedani kruh (2010) ter Tujka v hiši domačinov (1999) Erice Johnson Debeljak in na podlagi interdisciplinarnih teoretičnih izhodišč feministične teorije, migracijskih teorij in kulturnih študij izpostavlja dve individualni izkušnji migracije in integracije $\mathrm{v}$ slovenski prostor; $\mathrm{v}$ slovensko družbeno in kulturno realnost. $\mathrm{S}$ primerjalno analizo so $\mathrm{v}$ prispevku predstavljene tudi skupne točke in značilnosti, ki jih obe literarni ustvarjalki poudarjata in izpostavljata $\mathrm{v}$ svojih avtobiografskih literarnih delih ob tematizaciji svoje izkušnje migracije in poskusih integracije v novo slovensko okolje.

Ključne besede: izkušnja migracije, integracija, slovenski prostor, avtobiografija, literarne ustvarjalke, Stanislava Chrobakova Repar, Erica Johnson Debeljak

Experience of Migration and Integration into the Slovene Space in the Literary Works of Stanislava Repar Chrobáková and Erica Johnson Debeljak

The present article, through a literary analysis of the autobiographical literary works: Slovenka na kvadrat (2009) written by Stanislava Chrobakova Repar and Prepovedani kruh (2010) and 
Tujka v hiši domačinov (1999) written by Erica Johnson Debeljak and on the basis of the interdisciplinary theoretical issues of feminist, migration theories and cultural studies, highlights two individual experiences of migration and integration within Slovenia; into the Slovene social and cultural reality. It will be followed by a comparative analysis that points to the common observations and characteristics of both authors in relation to their experience of migration.

Key words: experience of migration, integration, Slovene space, autobiography, literary artists, Stanislava Chrobakova Repar, Erica Johnson Debeljak

\section{Uvod}

Prispevek na podlagi literarne analize avtobiografskih literarnih del dveh sodobnih literarnih ustvarjalk: Stanislave Chrobakove Repar (1960) in Erice Johnson Debeljak (1961) predstavi dve individualni izkušnji migracije in integracije $\mathrm{v}$ slovenski prostor. Skladno $\mathrm{s}$ to izkušnjo avtorici $\mathrm{v}$ izbranih literarnih delih pretresata tudi druge koncepte in razmerja: razmerje do nacionalne pripadnosti in njen pomen, koncepte meja, kulture, jezika, lastno identitetno pozicijo in tudi vlogo literarnega ustvarjanja ter umetnosti nasploh v novem okolju. Prispevek bo osvetlil tudi, kako se obe literarni ustvarjalki po izkušnji migracije opredeljujeta do novega bivanjskega in geografskega prostora, poleg tega pa tudi, ali so njuna literarna dela zaznamovana s transnacionalnimi in transkulturnimi prvinami.

Prispevek bo izkušnjo migracije posamezne literarne ustvarjalke, kakor se kaže v obravnavanih literarnih delih, v prvi vrsti izpostavil kot študijo primera. Teoretična podlaga bo interdisciplinarno zasnovana, temeljila bo predvsem na feministični teoriji, študijah migracij in kulturnih študijah. Feministična teorija bo v literarni analizi vključena predvsem v kontekstu pojmovanja sodobnih identitet, ki se spreminjajo in dograjujejo skladno s tranzitno naravo sodobne stvarnosti in pogostostjo migracijskih procesov v njej. Identitete sodobnih subjektov in migrantov zaradi spreminjanja geografskih prostorov namreč pridobivajo značaj večplastnosti, odprtosti in fluidnosti. Teorije migracij v zadnjih desetletjih v kontekstu proučevanja migracij $\mathrm{v}$ ospredje postavljajo individualne življenjske zgodbe posameznikov in posameznic (Milharčič Hladnik 2007). Migracije so namreč $\mathrm{v}$ sodobni stvarnosti pridobile razsežnosti, ki so bile predhod- 
no $\mathrm{v}$ zgodovini nepredstavljive, predvsem zaradi nepredvidljivosti in večsmernosti tega pojava (Papastergiadis 200: 1). V sodobni realnosti postajata tranzicija in migracije osnovna lastnost vseh človeških skupnosti, ti procesi spodbujajo kompleksnost, prav ta kompleksnost posledično pomeni, da je potrebno pri proučevanju migracij upoštevati številne, tudi kontradiktorne dejavnike: ekonomske kazalce, socialne, politične, družinske vezi, individualne razloge posameznikov, lokalne in nacionalne kvalifikatorje. Cela serija povezav in mrež namreč lahko vpliva na migracije posameznikov in tudi na njihovo integracijo v novo socialno in kulturno okolje (Hoerder 2002). Zelo pomembna značilnost, ki zaznamuje sodobne migracije in jo izpostavljajo kulturne študije, so tudi transnacionalne in transkulturne povezave migrantov, kar predstavlja njihovo delovanje in vključevanje v več nacionalnih in kulturnih prostorov hkrati (Vertovec 2001). Kompleksnost sodobnih migracijskih procesov tako podpira tiste pristope $\mathrm{k}$ njihovemu proučevanju, ki se osredinjajo na individualne življenjske zgodbe posameznih migrantov in migrantk, te se zrcalijo tudi v literarnih delih.

Literatura kot relevanten vir za proučevanje migracij je pridobila na pomenu $\mathrm{z}$ razvojem interdisciplinarnih pristopov pri proučevanju migracij. $\mathrm{V}$ tem kontekstu je pionirsko delo opravil raziskovalec Werner Sollors, ki je leta $1987 \mathrm{v}$ svoji študiji Beyond Ethnicity: Consent and Descent and American Culture prispeval prvo intedisciplinarno študijo, ta študija predstavlja stičišče literarne vede, kulturnih in migracijskih študij. Posebej pomembno vprašanje, ki mu pričujoči prispevek poskuša ponuditi jasen odgovor, je, ali lahko proučevanje literature migrantov in migrantk ter obravanava te literature kot enega od virov za proučevanje fenomena migracij, vodi do rahljanja stereotipov in pripomore $\mathrm{k}$ razvoju medkulturne zavesti. Prav razvoj medkulturne zavesti in rušenje stereotipov, ki so vezani na migrante in sam fenomen migracij, sta namreč temeljna pogoja za razvoj stabilne, odprte in varne družbe (Žitnik Serafin 2014).

Teoretika Benedict Anderson (1998) in Margaret R. Sommers (1994) enotno poudarjata tudi, da prav preko literature in akta literarnega ustvarjanja posameznik izgrajuje svojo lastno identiteto v svetu. To dejstvo je posebej zanimivo in pomenljivo $\mathrm{v}$ kontekstu pričujočega prispevka, saj obe $\mathrm{v}$ obravnavo vključeni literarni ustvarjalki v izbranih literarnih delih izpostavljata, da prav preko akta literarnega ustvarjanja prevprašujeta številne identitetne dileme in $\mathrm{v}$ interakciji $\mathrm{z}$ novim geografskim prostorom - slovenskim socialnim in kulturnim prostorom - izgrajujeta svojo identiteto. 


\section{Izkušnja migracije in integracije $\mathrm{v}$ slovenski prostor v literarnem delu Stanislave Chrobakove Repar}

Zakaj se moram 'razbliniti', da bi lahko spet 'postala', le tokrat po slovensko? Zakaj moram 'postati po slovensko', da bi lahko tu - kjer sem zdaj doma - živela kot polnovredna oseba? (Chrobáková-Repar, 2009: 49)

Stanislava Chrobakova Repar, pesnica, pisateljica, esejistka, prevajalka, literarna znanstvenica, urednica in založnica se je iz želje po skupnem življenju s Slovencem - filozofom, prevajalcem, esejistom in pesnikom Primožem Reparjem - leta 2001 iz Bratislave preselila v Slovenijo, v Ljubljano. Svojo izkušnjo migracije posebej izrazito problematizira v svojem avtobiografskem literarnem delu Slovenka na kvadrat. Večinsko pripovedno delo predstavlja literarni hibrid, vključuje dele avtoričinih predhodno objavljenih verzifikacij, dnevniške zapise, refleksije in dele korespondence. Vsa ta besedila kolažno predstavijo kompleksnost avtoričinega soočanja $\mathrm{z}$ izkušnjo migracije in novim življenjskim okoljem. Delo je sestavljeno iz desetih poglavij, ki jih avtorica naslovi z vodilno tematiko in podnaslovi kot razglednice. To poimenovanje podpoglavij je $v$ delu utemeljeno $s$ tem, da so poglavja časovno in geografsko določena, predstavljajo miselne utrinke in popise dogodkov, ki spominjajo na besedila na razglednicah in so izrazito avtobiografsko obarvani protagonistki zaznamovali vživljanje in soočanje s slovenskim prostorom, njegovim kulturnim in socialnim imaginarijem. Razglednicam v literarnem delu sledijo trije intervjuji, ki so jih $\mathrm{z}$ avtorico opravile tri sodobnice, ti še dodatno potrdijo avtobiografske navezave dela in ponujajo še bolj celovito in tudi kompleksno sliko avtoričine izkušnje migracije. V avtoričinih opombah lahko tudi preberemo, da delo povezuje miselni tok, ki kljub izraziti žanrski in ekspresivni pestrosti, literarno delo združuje in ga umešča na polje esejistike, $z$ izrazitimi avtobiografskimi in literarnimi značilnostmi (Chrobakova Repar, 2009: 247).

V delu Slovenka na kvadrat se avtorica opredeljuje do izkušnje migracije predvsem kot ženska in umetnica. Tako ob izkušnji migracije pretresa tradicionalna patriarhalna razmerja, razmerja moči, ki so se v njenem primeru izkazala predvsem $\mathrm{v}$ obliki radikalnega slovenskega birokratskega sistema $v$ času tranzicije $v$ Evropsko unijo, in zaradi katerega se je predvsem $\mathrm{v}$ začetni fazi integracije soočila s številnimi težavami. V svojem delu avtorica izpostavlja, da ni politična migrantka ali iskalka azila, temveč ženska, ki se je zaradi ljubezni in želje po skupnem življenju s Slovencem odpovedala ustaljenemu življenju in se podala $\mathrm{v}$ boj z birokracijo novo nastale države. 
$\mathrm{S}$ tem korakom $\mathrm{v}$ neznano je bila, kakor poudarja $\mathrm{v}$ svojem delu, za nekaj časa izbrisana; iz vseh slovaških podatkovnih baz in še ne vključena $\mathrm{v}$ podatkovne baze $\mathrm{v}$ novem okolju. Znašla se je $\mathrm{v}$ nekem nedoločenem in vmesnem prostoru; neopredeljena, nikogaršnja, s tem pa tudi neomejena. Že z izbiro naslova literarnega dela se avtorica preigrava s svojo kompleksno identiteto, ki jo ves čas izpostavlja tudi na vsebinski ravni obravnavanega literarnega dela. Slovenka $\mathrm{v}$ slovaškem jeziku namreč pomeni Slovakinjo, v slovenskem pa Slovenko, ta jezikovna igra nakazuje na dvojnost in kompleksnost identitetne pozicije literarne protagonistke. Ta kompleksna in dvoplastna identitetna pozicija je še radikalizirana $\mathrm{z}$ njenimi številnimi delovalnimi vlogami, profesionalno namreč posega na polje raziskovanja, urednikovanja, pisateljevanja in pesnjenja, esejistike, uredništva in založništva. Vse te profesionalne vloge dojema kot vitalno povezane, prepletene in soodvisne, četudi birokratski sistem zahteva, da se enoznačno in jasno opredeli le z eno delovalno vlogo. Od te opredelitve so namreč odvisne subvencije, honorarji in številni drugi privilegiji. Avtorica se v tem kontekstu približuje konceptu fluidnih ali nomadskih identitet, kakor jih imenuje feministična teoretičarka Rosi Braidotti (2011), in je pogosto povezan prav z izkušnjo migracije ter vplivom tranzitnega značaja sodobne stvarnosti na posameznikovo identitetno izgradnjo. Tako tranzitna stvarnost kot izkušnja migracije namreč povzročita identitetne odklone, spremembe, prilagoditve, ki se dogajajo skladno z menjavanjem stvarnosti, geografskih pozicij ter nacionalnih, socialnih in kulturnih imaginarijev (Braidotti, 2011 in Stanford Friedman, 1998).

Enoznačnemu opredeljevanju in vkalupljanju njene identitete v predvidljive in dane okvire se avtorica izrazito in vztrajno upira v svojem literarnem opusu in izpostavlja, da je njena kompleksnost plod trdega preteklega dela in prizadevanj, njenih različnih osebnih interesov in profesionalnih ambicij, ki jih ne more in zmore reducirati zgolj na eno delovalno vlogo. V kontekstu boja $\mathrm{z}$ birokracijo $\mathrm{v}$ novem življenjskem okolju se dotika predvsem problematike ohranjanja svoje osebnostne samobitnosti, kulturnega in profesionalnega ozadja, ki si ju je pridobila v primarni domovini. $\mathrm{V}$ Sloveniji pa sta - zaradi dolgotrajnega in zapletenega poteka birokratskih postopkov - za nekaj časa pod vprašaj postavljeni celo njena finančna neodvisnost in pridobljena izobrazba. Tudi te na videz osnovne in pretekle pridobitve so bile s selitvijo v novo okolje in do pridobitve slovenskega državljanstva za nekaj časa popolnoma izbrisane, $\mathrm{v}$ tem položaju se avtorica sprašuje: 
Zakaj torej Slovenija služi na usodah ljudi, kot sem jaz: vzame in ne ponudi ničesar, pusti pa $\mathrm{v}$ stanju breztežnosti? Bolj natančno: vrže te $\mathrm{v}$ zrak! Zakaj me spravlja $\mathrm{v}$ položaj zajedalca: formalno blokira, razveljavlja, ne priznava mojih usposobljenosti in sposobnosti, pri čemer je njihova ponovna pridobitev samo še odkupovanje iz podložništva, v katerega sem bila samodejno vržena? (Chrobáková-Repar, 2009: 39)

Ironija je v izbranem literarnem delu Stanislave Chrobakove Repar pomembna literarna strategija. Ironija velja tudi $\mathrm{v}$ feministični teoriji za pomembno komponento, Donna Haraway (1990) izpostavlja, da je v feministčni teoriji politika jezika zelo izrazito povezana s temeljnimi feminističnimi problematikami. Ironija je $\mathrm{v}$ delih ustvarjalk pogosto uporabljena $\mathrm{v}$ kontekstu prevpraševanja kontradiktornih, delnih, odprtih in fluidnih identitet, ki so bile predhodno problematizirane. Ironična perspektiva omogoča, da kontradiktornost, ki je prisotna na ravni besednega poimenovanja, sovpade in se zrahlja. S to literarno tehniko v svojem literarnem delu avtorica pogosto tudi rahlja težo problematike - in izpostavlja, da je bila s prehodom v novo okolje pod vprašaj in skorajšnjemu izbrisu podvržena tudi njena osebnostna identiteta. S prehodom $v$ novo okolje je bilo spremembam podvrženo tudi njeno lastno ime in pridobilo je novo obliko, tako ironično izraža:

[...] zdaj sem Slovenka na kvadrat, v vsakem od obeh jezikov ... torej sem (bivša) Chrobáková - v angleškem prevodu: Beeltova ... pred tem sem bila (čisto kratko) Kvapilova ... in od zdaj bom Reparova ... v bistvu le Repar, brez pregibanja. Podpisala sem uradni dokument, da soglašam s to obliko svojega priimka tudi na ozemlju s pregibanjem. Namreč, če se prav razumemo, da soglašam z uradnim »kvarjenjem « mojega priimka na Slovaškem. Za to sem morala podpisati izjemo pravila. (Chrobáková-Repar, 2009: 21)

Integracija $\mathrm{v}$ slovenski prostor ima $\mathrm{v}$ delu Slovenka na kvadrat tudi številne pozitivne konotacije in Stanislava Chrobakova Repar je v Sloveniji presenečena in navdušena nad njeno raznolikostjo, kljub njeni majhnosti. Ob tem avtorica opaža in poudarja tudi neizmerno navezanost slovenskega človeka in njegovega življenja na naravo, njene cikle in zemljo in to dejstvo jo navdaja $\mathrm{z}$ občudovanjem. Sama je odraščala $\mathrm{v}$ mestu in kot mestni otrok $\mathrm{z}$ naravo ni imela nikdar pravega in pristnega stika, o njenem pomenu se 
tudi ni spraševala in ni nikdar zares doumela človekove soodvisnosti od nje. Ob navezavi slovenskega človeka na naravo Stanislava Chrobakova Repar analitično zaznava tudi tradicionalne vzorce, ki so globoko zakoreninjeni $\mathrm{v}$ zavest slovenskih ljudi in $\mathrm{v}$ njihovo delovanje, tudi rigidnost, ki jo ti tradicionalni vzorci pogosto zbujajo pri ljudeh. Med seznanjanjem s slovensko družbo poudarja, da iz primeža tradicionalnih vzorcev slovenski človek težko izstopa, zato je hkrati tudi obvarovan pred novimi, modernimi oblikami kapitalističnega zasužnjevanja. Avtorica kot kolektivni sindrom slovenskega človeka izpostavlja tudi osamo, nekomunikacijo in nesodelovalni značaj slovenskih ljudi. Ta osama se polasti tudi nje same.

Neka notranja osamljenost - ki se izkazuje tudi fizično - je namreč $v$ tej prelepi deželi absolutna stvarnost, a ne le zame, temveč tudi za moje tukajšnje sobivajoče. Gre za popolnoma običajen fenomen, s katerim se tu srečujemo na ulicah, $\mathrm{v}$ glavnih prostorih, na gozdnih stezah, $\mathrm{v}$ gostilnah, $\mathrm{v}$ (ne)komunikaciji. Ljudje hodijo sami, ali ostajajo sami, bolj zaupno se niti ne zbližajo, ali prej izjemoma kot ponavadi. Ne delijo si osebnih izkušenj, prej sporočajo o družbenih presežkih svojega delovanja. In potem si svoj skrčeni, emocionalno sestradani ego ojačajo v ustanovah in prek institucij, v katerih so zaposleni. Kar je še slabše - ta kombinacija človeškega deficita s sistemsko represijo. Vsak ljubosumno nadzoruje svoj mali teritorij. (Chrobáková-Repar, 2009: 152)

V svojem literarnem delu Stanislava Chrobakova Repar nenehno vzporeja življenje v Bratislavi s tistim v Ljubljani, te primerjave izvaja na ravni vsakdanjega življenja, še bolj pogosto pa na ravni jezika in njegove rabe. Opaža namreč, da sta si slovenski in slovaški jezik sicer podobna in da je s tega vidika njena jezikovna integracija olajšana. Hkrati opaža tudi, da si oba slovanska jezika določen nabor besedišča delita, vendar z očitno razliko, da imajo nekateri izrazi v drugem jeziku drugačen pomen, so zastareli ali niso več v rabi. Primerjave izvaja tudi v navezavi na historično situacijo in slovensko nacionalno zgodovino, ob tem izpostavlja tudi povezavo Slovenije z ostalimi državami na Balkanskem polotoku, trenja na meji med Slovenijo in Hrvaško in na tržaškem območju. S pozicije analitične znanstvenice s historičnega vidika komentira tudi položaj Ljubljane, ki izgublja svoj centralistični položaj in unifikacijsko funkcijo.

Ob izkušnji migracije Stanislava Chrobakova Repar v delu Slovenka na kvadrat prevprašuje tudi in predvsem svojo vlogo literarne ustvarjalke, znanstvenice, kulturne posrednice in umetnice nasploh. Sprašuje se, na kakšen način se ob uveljavljenem položaju v slovaških kulturnih krogih ak- 
tivno vključiti tudi v slovensko kulturno življenje, seveda $\mathrm{z}$ vsemi različnimi delovalnimi vlogami. $V$ tem kontekstu se že četrta razglednica tematsko ne osredinja več na problematiko boja $\mathrm{z}$ birokracijo in na težave pri integraciji $\mathrm{v}$ slovenski prostor, tu protagonistko kot bralci že lahko najdemo $\mathrm{v}$ vlogi organizatorke festivala Vilenica in tik pred izidom njene pesniške zbirke Angelske utopije v slovenskem prevodu.

Stanislava Chrobakova Repar v svojem delu ironično izpostavlja, da mora v novem življenjskem prostoru znova postati, se uveljaviti, zastopati svoje ideale - tokrat po slovensko. Kljub začetnim težavam in dolgotrajnemu boju $\mathrm{z}$ birokracijo pa jasno poudari, da sta ji izkušnja migracije in pozicija nekje vmes ponudili možnost za kritičen pretres sodobne stvarnosti, kjer se je znašla, izostrili sta njeno izjemno kritično perspektivo na stvarnost in zavest, da če hoče preživeti in uspeti, si mora ustvariti sistem vrednot, ki je neodvisen od družbenega, nacionalnega in kulturnega imaginarija v katerem živi. Ugotavlja tudi, da je doslej porabila preveč časa in energije, da bi se uveljavila in vključila $\mathrm{v}$ dan sistem, upoštevala na videz nepremakljive norme in pravila. To jo spodbudi, da strukturira svoj lasten sistem pravil, $\mathrm{v}$ nadnacionalnem in nadkulturnem položaju, neodvisno od statusnih določil. Izkušnja migracije jo je postavila v pozicijo življenja na robu, na meji, v vmesnem prostoru med dvema nacionalnima državama, socialnima in kulturnima imaginarijema, prav zato se $\mathrm{v}$ njeni zavesti tudi radikalizira želja po tem, da spregovori kot angažirana in izjemno kritična avtorica, tako izraža:

Resničen občutek vesoljske ganjenosti me je speljal takrat, ko sem svoje (vsiljeno in nemirno) lebdenje na meji možnega, ki so jo določili drugi, lahko preoblikovala $\mathrm{v}$ raziskovanje skrivnostnih ali prepovedanih svetov onkraj, oziroma, celo znotraj te meje. Meje, ki je vendarle zmeraj tudi del neke pragmatične kolektivistične projekcije in samo/opredelitve.

$[\mathrm{K}] \mathrm{o}$ si brez zaščite nekih »a priori« (prepričanj, normativov, pričakovanj ...), ki te zmeraj vsaj toliko ovirajo, kolikor ohranjajo, recimo $\mathrm{v}$ nekem družbenem ali zgodovinskem kontekstu. Namreč, ko se jih zmoreš otresti, ker jih - enostavno - spregledaš kot sredstvo nekoga ali nečesa, kar je zate izgubilo bistveni pomen, jih pa več ne sprejemaš kot danost. (Chrobáková-Repar, 2009: 68-69)

Kot angažirana avtorica, ki se je znašla $v$ vmesnem prostoru med dvema nacionalnima imaginarijema in kulturama, gradi svojo identiteto $\mathrm{v}$ 
neki nadnacionalni in nadkulturni poziciji, $\mathrm{v}$ medprostoru obeh kultur in nacionalnih prostorov. Ta vmesna pozicija ji omogoča neodvisnost od statusnih definicij, ki jih dodeljujeta družba in birokracija. Prav tako ji ta vmesni prostor, pozicija na robu, na meji, občutki ranljivosti, nestabilnosti in izpostavljenosti, omogočajo širši in bolj izostren pogled na stvarnost in življenje. V njej zbudijo upornost in kritičnost.

Avtorica poudarja, da svojo individualno in umetniško svobodo ne more najti znotraj danega socialnega sistema in jo lahko išče zgolj v odmiku od družbenih sistemov, z vzpostavitvijo individualnega sistema vrednot in kriterijev. Izkušnja migracije in širina pogleda, ki jo ta izkušnja prinaša, okrepi avtoričino samozaupanje in vero $\mathrm{v}$ lasten sistem vrednot ter njeno individualnost. Prav sprejemanje in izražanje individualnosti je po njenem mnenju tudi ključni element, ki deluje $\mathrm{v}$ smeri sprejemanja in $\mathrm{v}$ prid dekonstrukcije hierarhičnih razmerij in se lahko zoperstavlja kulturnemu in nacionalnemu elitizmu.

\section{Izkušnja migracije in integracije $\mathrm{v}$ slovenski prostor v literarnih delih Erice Johnson Debeljak}

[...] resnično čutim, kot da bi moje srce tu bilo počasneje, kot da so se ritem, impulzi in užitki mojega življenja upočasnili v bolj blagem kroženju. (Johnson Debeljak, 1999: 194)

Erica Johnson Debeljak se je v Slovenijo priselila leta 1993. Razlog za njeno migracijo je bila tako kot v primeru Stanislave Chrobakove Repar ljubezen in želja po skupnem življenju $\mathrm{z}$ bodočim soprogom, pesnikom Alešem Debeljakom. Svojo izkušnjo migracije avtorica tematizira v literarnih delih Prepovedani kruh (2010) in Tujka v hiši domačinov (1999). Obe deli sta v slovenskem jeziku izšli v prevodu, vsebinsko se dopolnjujeta in bosta v nadaljevanju obravnavani združeno. Deli na avtobiografskih temeljih predstavljata spoznavanje Erice Johnson Debeljak in Aleša Debeljaka med njegovim študijem v New Yorku in željo po skupnem življenju, ki je Erico slednjič pripeljalo v Slovenijo. Erica Johnson Debeljak se je v začetku devetdesetih let iz izrazito razvite države in mesta New York preselila v Slovenijo, ki se je ravno soočila $\mathrm{z}$ osamosvojitvijo in razvojem svoje lastne narodne identitete.

V izbranih delih Erica Johnson Debeljak sprva razpravlja o soočenju družine in kroga prijateljev $\mathrm{v}$ Ameriki z dejstvom, da se bo preselila v Slovenijo, ob tem opaža, da njene družinske člane odločitev ni pose- 
bej presenetila, saj so imeli v družini že predhodno primere medkulturnih ljubezenskih zvez in selitev. Poudarja tudi, da sta jo drugost in drugačnost tudi osebno izjemno privlačila, odraščala je namreč ob liberalni materi in v državi z zelo liberalnimi nazori. Zanimiv pa je bil odziv širše okolice na njeno odločitev, odziv prijateljev in znancev, ki so Slovenijo pogosto enačili $\mathrm{s}$ kraji, kjer se odvijajo vojne, $\mathrm{z}$ revščino in celo $\mathrm{z}$ muslimansko vero. Ti stereotipi in posplošene sodbe pa niso ključno vplivale na njeno odločitev in ta je ves čas ostala trdna. V izkušnji migracije sama vidi možnost bogatitve svojega horizonta spoznanj, možnost soočenja s podobo Drugega in celo vživitev vanjo.

Erica Johnson Debeljak razmišlja v kontekstu migracije o človeških identitetah in izpostavlja kompleksnost človeških identitet, predvsem identitet migrantov. Izpostavlja, da je izkušnja migracije po njenem mnenju v prvi vrsti zmožnost, da svoji identitetni poziciji dodajamo nove plasti. Trdi, da četudi se človek sooči z izkušnjo migracije kot odrasel, ima še vedno možnost, da svoji identitetni poziciji dodaja nove odtenke, ki jih izkušnja migracije, soočanje $\mathrm{z}$ novimi geografskimi območji ter kulturnimi in nacionalnimi imaginariji prinašajo. Tudi Erica Johnson Debeljak tako v izbranih literarnih delih vpeljuje koncept fluidnih identitet, ki se izgrajujejo $\mathrm{v}$ povezavi $\mathrm{z}$ menjavanjem geografskih pozicij.

Erica Johnson Debeljak se z zavestjo o izkušnji migracije, ki se bliža, že v New Yorku pripravlja na soočenje z novim in neznanim. Zaveda se, da bo zanjo zelo problematičen predvsem jezikovni preskok, tako se že v Ameriki preizkuša v prvih poskusih učenja slovenskega jezika. Preko poslušanja posnetkov, ki so namenjeni učenju slovenskega jezika, si ob izjemni zvočnosti novega jezika slika tudi idealizirano podobo te podalpske deželice in njenega glavnega mesta, kjer bo kmalu živela. Ko končno napoči čas za selitev in Erica prvič obišče Ljubljano, pa je trk predstav in realnosti zelo radikalen. Ljubljano namreč prvič uzre kot sivo mesto s socialistično gradnjo, kjer je, kakor se izrazi, vsakršno estetsko načelo opuščeno, le gore v ozadju mehčajo podobo tega mesta. Vendar Erice to dejstvo ne demotivira in $\mathrm{z}$ veliko elana in navdušenja raziskuje svoje novo bivanjsko okolje. Slovenija jo preseneča s svojo majhnostjo in raznolikostjo hkrati, slednja jo tudi bega, saj se zaveda, da ne bo nikdar obvladala njenih številnih socialnih, kulturnih in tudi jezikovnih odtenkov.

V novem okolju se ob fascinaciji nad majhnostjo slovenske države tudi prvič zares seznani z občutki pripadnosti skupnosti, z domačnostjo, kon- 
cepti, ki jih predhodno ni poznala oz. ji niso ničesar pomenili, tako izraža odsotnost teh občutkov:

Odsotnost toplih jesenskih popoldnevov, ko srkaš domače vino pod sosedovo kutino. Odsotnost tistega otipljivega, drhtečega čustva [...] Ne verjamem, da sem kdaj prej tako močno občutila kako navzočnost. Kasneje, ko sem ležala na ozki postelji v propadajoči stolpnici na Proletarski v toplem zalivu moje skupnosti dveh, sem bila srečna, da sem jo spoznala. Bila je zelo daleč od mojih sanjskih predstav o Ljubljani. Toda njena dvojnost, njena ostrina in melanholija, sta me zasvojili. (Johnson Debeljak, 1999: 68)

S temi novimi spoznanji postopoma opušča poviševanje občutka anonimnosti, ki jo je spremljal med življenjem v velikem mestu. Življenje v majhnem mestu, kjer se le redko zgodi, da na cesti ne sreča vsaj enega znanca, ji postaja vedno bolj domače in celo bolj avtentično. Z Alešem si utira pot med slovenske in jugoslovanske kulturne kroge, seznanja se z rokovsko subkulturo nekdanje Jugoslavije, z jugo-nostalgijo po izgubljenem bratstvu in enotnosti. Seznani se tudi s pomenom pojmov nostalgija in hrepenenje, ki sta po njenem mnenju tako zelo značilna za jugoslovanske in slovenske ljudi.

Tudi Erica Johnson Debeljak se v začetni fazi integracije v slovenski prostor sooči z neizprosnim bojem z birokracijo novonastale države. $\mathrm{V}$ birokratski gonji z Alešem pristaneta, ko se želita poročiti. Za Erico predstavlja ta položaj in boj z uradniki velik šok, daje ji občutek popolne nemoči in nezmožnosti, da lahko upravlja s svojim osebnim življenjem. V strogi birokratizaciji vidi kategorizacijo in omejevanje posameznikove svobode in nenehno klasificiranje človeških identitet. Kljub vsemu pa poudarja, da je bila tega deležna zgolj na formalni ravni njenega začetnega vživljanja v slovenski prostor, njeno vsakdanje življenje je bilo bolj sproščeno in prepuščeno naključjem. Ob tem se zaveda tudi, da ima kot Američanka v slovenski družbi relativno privilegiran položaj - v primerjavi z drugimi priseljenci, predvsem tistimi iz nekdanjih jugoslovanskih republik. Izpostavlja, da so ti obravnavani veliko slabše in so deležni številnih negativnih konotacij in stereotipov. Svoj položaj tujke dojema kot privilegiran, kot tisti, ki ji omogoča širšo in kritično perspektivo na stvarnost, tako izraža:

Tujec ima nekaj resničnih prednosti, ne samo šaljivih. Navsezadnje mi je prav vloga tujke omogočila, da sem opazovala dve enako od- 
bijajoči strani iste medalje. Prisilila me je, da sem poskušala razvozlati gordijski vozel zakonov o tujcih v mladi slovenski državi da sem začela razlikovati med navadno birokracijo in njeno bolj sadistično kafkovsko sestrično; da sem se postavila po robu omalovaževalnim pogledom; da sem se iz izkušnje učila, kako je, če si enkrat za spremembo prejemnik takšnega ponižujočega ravnanja. (Johnson Debeljak, 1999: 129)

O tujcu kot tistem, ki izstopa iz ustaljenih socialnih skupnosti in še ni popolnoma vključen vanje in ima s tem privilegiran položaj in možnost kritične perspektive na to družbo, razpravlja tudi feministična teoretičarka Julia Kristeva v svojem teoretičnem delu Strangers to ourselves (1991). Teoretičarka poudarja, da nam ta pozicija omogoča uvid v tujskost $v$ ustroju identitete vsakega posameznika, ponuja možnost projekcije in zavedanja, da sta tujskost in nedorečenost osnovna gradnika vsake identitete. Pozicija tujca je kreativna pozicija, ki sprevrača ustaljene vzorce mišljenja in udejstvovanja. Omogoča širše perpektive uvida, preko ozkih opredelitev identitete, nacionalnih, kulturnih in etničnih determinant. Omogoča odmik od ustavljenih identitetnih pozicij in s tem kritičnost perspektive na navidezne danosti in norme.

Učenje slovenskega jezika, preko katerega se je Erica Johnson Debeljak pravzaprav že v Ameriki začela seznanjati z novo deželo, je v novem okolju posebno trd oreh, saj ne more iskati pomoči v nobenem znanem romanskem jeziku. Kljub temu je očarana nad zvočnostjo slovenščine, ki jo v angleškem jeziku zelo pogreša, posebej v jeziku poezije. Skladno z usvajanjem novega jezika pa izraža, da pridobiva tudi novo identiteto, njen imaginarij se spreminja in dograjuje. Jezik je v njenem primeru izrazito prikazan kot osnovni gradnik njene identitete. Njena nesuverenost v slovenskem jeziku je sprva razlog, da se izogiba družbeni interakciji, saj ne zmore komunikacije. In prav to jo $\mathrm{v}$ začetni fazi njenega vživljanja $\mathrm{v}$ slovenski prostor zelo obremenjuje, saj je zelo družaben in komunikativen tip osebnosti, $v$ novem okolju pa se $\mathrm{v}$ začetnih fazah ne zmore niti izraziti. $V$ tem obdobju se bolj kot v družbeno realnost zateka v intimo dvojine, le tam lahko izrazi svojo individualnost, samo tam ima zares občutek, da je razumljena.

Erica Johnson Debeljak v svojih avtobiografskih delih izraža, da se je z migracijo odpovedala svojemu nekdanjemu življenju, poklicni poti uspešne bančnice in se znašla v popolnoma novem okolju, vendar kljub temu poudarja, da je z izkušnjo migracije veliko pridobila. Prav v Sloveniji se je namreč uveljavila kot pisateljica in začrtala svojo pisateljsko pot. Dobro raz- 
viti komunikacijski kanali so ji omogočili tudi ohranjanje in vzdrževanje stikov s sorodniki, prijatelji in znanci v njeni primarni domovini. Te transnacionalne in transkulturne povezave - kakor poudarja Steven Vertovec v svojem teoretičnem delu Transnationalism and identity (2001), migrantom omogočajo simultano delovanje in ohranjanje povezav med več nacionalnimi in kulturnimi prostori in tovrstno delovanje velja za temeljno značilnost sodobnih migracij, pomeni obogatitev in omogoča kritične primerjave - Erici Johnson Debeljak nudijo kritično distanco do življenja - tako v Ameriki kot v Sloveniji. Njena identiteta pa se tako izgrajuje v medprostoru med dvema kulturama:

Moje nihanje med dvema sklopoma idej in prepričanj, med dvema duhovnima domovinama, se je pokazalo kot najbolj razsvetljujoči, čeprav nikoli dokončno rešljivi vidik izgnanstva. To je stanje večnega preseljevanja in odkrivanja. Pred seboj vidim sprevod novih ljudi in znamenitosti, novo kulturo, ki jo neka roka tke na platno mojega preteklega življenja. Posledica tega je, da izgubljam občutek za smer. Pogosto ne morem več reči, kaj je prav ali res, kaj bolj živo in stvarno: ostre postave, ki prevladujejo $\mathrm{v}$ ospredju tapiserije, ali miglajajoče sence moje mladosti, ki zdaj bledijo v daljavi. Slovenska stališča branim pred Američani in ameriška pred Slovenci. Kakršnakoli trdna oporna točka ali stroga ideološka zveza, ki me je še pripenjala v mladosti, je izgubila svoj železni prijem. (Johnson Debeljak, 1999: 137)

V svojem literarnem opusu Erica Johnson Debeljak izraža hvaležnost za izkušnjo migracije in poudarja, da ji je prav pozicija nekje vmes zbistrila pogled, izpostavlja, da v novem okolju zaživi bolj avtentično, tudi bolj $\mathrm{v}$ stiku z naravo, po zgledu slovenskih ljudi jo začne vrednotiti in ceniti. Opaža, da sta tradicija in navezanost na naravo globoko zakoreninjena $\mathrm{v}$ slovenskih ljudeh in to pojmuje kot zelo pozitivno lastnost, ki omogoča človeku bolj pristno in prvobitno življenje, uspešen boj s kapitalizmom in konzumerizmom. Tudi kategorija časa pridobi v novem okolju v njeni percepciji nove razsežnosti, občutek ima, da ji je čas tukaj odmerjen počasneje. Ob tem izpostavlja tudi, da je bila med življenjem v Ameriki bolj izrazito zaverovana $\mathrm{v}$ dosežke znanosti in tehnologije, skladno s tem pa je izgubljala tudi občutek za pravo mero. Izpoveduje, da je izkušnja migracije predvsem in posebej izostrila njeno zmožnost prilagajanja spremembam. S to izkušnjo se je znašla v poziciji Drugega, ki jo je od nekdaj privlačila, prav ta položaj jo spodbudi tudi k literarnemu ustvarjanju. 


\section{Sklep}

Stanislava Chrobakova Repar in Erica Johnson Debeljak v izbranih avtobiografskih literarnih delih tematizirata svojo izkušnjo migracije v Slovenijo, v Ljubljano. Obe sta se - sicer iz različnih geografskih območij, različnih kulturnih, socialnih in političnih imaginarijev, ena iz Slovaške, druga iz Amerike - preselili v Slovenijo. Razlog za migracijo je bila v obeh primerih ljubezen in želja po skupnem življenju s Slovencem, kulturnim delavcem Primožem Reparjem oziroma Alešem Debeljakom. Glede na različno socialno in kulturno ozadje $\mathrm{v}$ katerem sta literarni ustvarjalki doživljali primarno socializacijo, preživeli tudi velik del svojega odraslega življenja in se uveljavili na poklicnem področju, bi lahko kot bralci sklepali, da bo vživljanje v slovenski prostor za Erico Johnson Debeljak bolj težavno in se bo med integracijo soočila $\mathrm{z}$ bolj radikalnimi in morda celo nepremostljivimi socialnimi, jezikovnimi in kulturnimi razlikami. Slovaška je bila namreč v obdobju, ko se je Stanislava Chrobakova Repar priselila v Slovenijo, predvsem $\mathrm{v}$ zgodovinskem, političnem in socialnem smislu, bolj podobna Sloveniji kot Amerika v začetku devetdesetih let, ko se je sem priselila Erica Johnson Debeljak. Kljub temu prav Erica Johnson Debeljak s svojo osebnostno odprtostjo in pripravljenostjo na soočenje s spremembami teh ne dojema drastično, izpostavlja, da je v Sloveniji zaživela bolj avtentično. Prav tu se je seznanila $\mathrm{z}$ občutkom pripadnosti in obračunala $\mathrm{z}$ anonimnostjo, ki jo je obdajala med življenjem v velikem mestu, v New Yorku. V Sloveniji je našla tudi vzgib za literarno ustvarjanje, ki je v obliki književnih del doslej izhajalo v slovenščini v prevodu. Tudi Stanislava Chrobakova Repar ob vživljanju v slovenski prostor opaža, da se je prav tu senzibilizirala za naravo, jo začela upoštevati in ceniti.

Obe literarni ustvarjalki ob vživljanju v slovenski prostor izpostavljata izjemno birokratizacijo, ki je zavladala v slovenski državi po osamosvojitvi, in v boj s katero sta se tudi sami podali, da bi lahko uveljavili svoje pravice in delovalne vloge. Obe literarni ustvarjalki izražata prevzetost nad lepotami slovenske narave in vseprežetost $\mathrm{z}$ njo, hkrati pa globoko vero, zaupanje in strahospoštovanje slovenskega človeka in njegovo odvisnost od narave in njenih ciklov. Ob tem se tudi obe literarni ustvarjalki dotikata zakoreninjenosti slovenskega človeka v tradicionalnih vzorcih, ki jih Stanislava Chrobakova Repar - kot izjemno natančna in kritična opazoval$\mathrm{ka}$ - deloma povezuje z okostenelostjo in nekritičnim ponavljanjem preteklosti, tako kot Erica Johnson Debeljak pa tudi z bolj avtentičnim življen- 
jem in uspešnim uporom kapitalizmu in konzumerizmu, novimi oblikami zasužnjevanja in odvisnosti, ki jih prinaša sodobna stvarnost.

Stanislava Chrobakova Repar in Erica Johnson Debeljak v svojih literarnih delih poudarjata koncept kompleksnih in fluidnih identitet migrantov in migrantk, ki se izgrajujejo $\mathrm{v}$ skladu $\mathrm{z}$ menjavanjem geografskih pozicij, življenjskih izkušenj, kulturnih in socialnih imaginarijev, s katerimi prihajajo v stik. Izkušnja migracije je v literarnih opusih obeh ustvarjalk prikazana kot tista, ki ju je razdvojila med dva nacionalna in kulturna imaginarija, ju postavila $\mathrm{v}$ mejni položaj, $\mathrm{v}$ medprostor med obema domovinama. Ta vmesni prostor obe literarni ustvarjalki pojmujeta pozitivno, to ni pozicija nepripadnosti, temveč prostor, ki odpira možnost ustvarjalni domišljiji, ponuja možnosti soočanja in sprejemanja drugega, kritično in angažirano perspektivo na življenje in življenjske izkušnje. Ta položaj generira tudi njuno literarno ustvarjalnost.

$\mathrm{Z}$ motivi in temami, ki se dotikajo avtobiografskih izkušenj migracije in vživljanja $\mathrm{v}$ slovenski prostor, avtorici bogatita slovenski literarni sistem, spodbujata medkulturnost in $\mathrm{v}$ slovenski literarni in socialni imaginarij vnašata kritične poglede intelektualk in migrantk. V slovenski prostor in v slovenski literarni sistem vnašata poglede, ki jih tradicionalno lahko opredeljujemo kot poglede Drugega, prav te perspektive so posebej dragocene za kritično refleksijo delovanja slovenskega naroda. Literarni ustvarjalki v izbranih literarnih delih poudarjata tudi nove poglede na identitete migrantov in migrantk, ki se izgrajujejo $\mathrm{v}$ interakciji $\mathrm{z}$ različnimi socialni$\mathrm{mi}$ in kulturnimi okolji ter transnacionalno in transkulturno delovanje migrantov in migrantk.

Viri

Chrobakova Repar, Stanislava. 2009. Slovenka na kvadrat. Ljubljana: KUD Apokalipsa.

Johnson Debeljak, Erica. 1999. Tujka v hiši domačinov. Maribor: Obzorja.

--. Prepovedani kruh. Ljubljana: Modrijan.

\section{Literatura}

Anderson, Benedict. 1998. Zamišljene skupnosti: o izvoru in širjenju nacionalizma. Ljubljana: SH.

Braidotti, Rosi. 2011. Nomadic Subjects, Embodiment and Sexual Difference in Contemporary Feminist Theory. New York: Columbia University Press. 
Haraway J. Donna. 1990. A Manifesto for Cyborgs: Science, Technology, and Socialist Feminism in the 1980s. Feminism/Postmodernism, ed. L. Nicholson. New York: Routledge.

Hoerder, Dirk. 2002. Cultures in contact: world migrations in the second millennium. Durham; London: Duke University Press.

Kristeva, Julia. 1991. Strangers to Ourselves. New York: Columbia University Press.

Milharčič Hladnik, Mirjam. 2007. Avto/biografičnost narativnosti: metodološko teoretični pristopi v raziskovanju migracijskih izkušenj. Dve domovini, št. 26 , str. $31-46$.

Papastergiadis, Nikos. 200o. The turbulence of migration: globalization, deterritorialization, and hybridity. Cambridge, UK: Polity Press; Malden, Mass.: Blackwell.

Somers, Margaret. 1994. The narrative constitution of identity: A relational and network approach. Theory and Society 23(5): 605-649.

Stanford Friedman, Susan. 1998. Mappings. Feminism and the Cultural Geographies of Encounter. New Jersey: Princeton University Press.

Vertovec, Steven. 200I. Transnationalism and identity. Journal of Ethnic and Migration Studies, Vol. 27, No. 4; 573-582.

Žitnik Serafin, Janja. 20I4. Vloga izseljenske/priseljenske književnosti in literarne vede pri raziskovanju migracij. Dve domovini, št. 39, str. 3I-42. 


\title{
Pesniška samorefleksija v poeziji Primoža Čučnika
}

\author{
Mateja Eniko \\ Fakulteta za humanistiko, Univerza v Novi Gorici \\ School of Humanities, University of Nova Gorica \\ mateja.eniko@ung.si, mateja.eniko@gmail.com
}

Pesniška samorefleksija oziroma metapoezija obsega premisleke, povezane s poezijo in pesnikom kot ustvarjalcem. Interpretativna analiza metapoezije v pesniških zbirkah Primoža Čučnika (1971) pokaže, kako se v literarnih podobah zrcalita vloga poezije in položaj pesnika v kontekstu spremenjenih zgodovinskih in duhovno-literarnih okoliščin. Čučnik v avtotematskih pesmih reflektira odnos do pesniškega poslanstva in poezije, razmišlja o viru navdiha, intertekstualnih odnosih, poeziji kot odzivu na družbeno dogajanje, jeziku in ustvarjalnem procesu. S pesniško samorefleksijo pesnik utemeljuje poezijo in sebe kot ustvarjalca ter se umešča v literarni in družbeni kontekst.

Ključne besede: Primož Čučnik, mlada slovenska poezija, samorefleksija, metapoezija, družbeni kontekst

\section{Poetic Self-Reflection in the Poetry of Primož Čučnik}

Poetic self-reflection or metapoetry deals with considerations associated with poetry and the poet as the creator. The interpretative analysis of metapoetry in the works of Primož Čučnik (1971) shows how the literary images mirror the role of poetry and the position of the poet in the context of changed historical and spiritual-literary circumstances. In auto-thematic poems Čučnik reflects the attitude to poetry and poetic mission, thinks about 
the source of inspiration and intertextual relations, about poetry as a response to social events, about language and creative process. With poetic self-reflection the poet justifies poetry and himself as a creator and positions himself in the literary and social context.

Key words: Primož Čučnik, young Slovenian poetry, self-reflection, metapoetry, social context

\section{Kratka teoretska osvetlitev}

Pesniška samorefleksija je pomensko enakovredna s konceptom metapoezije oziroma avtotematske poezije, $\mathrm{v}$ določeni točki pa se povezuje tudi s konceptom samonanašalnosti. V uvodu zbornika Self-Reflexivity in Literature je izpostavljeno, da je samorefleksija "tako odraz kot tudi osnovna zahteva moderne racionalnosti in samozavedanja« (Huber, Middeke, Zapf 2005, 7).

Metapoezija zajema širok razpon tem. Vključuje razmislek o pesniku in njegovi vlogi, ustvarjanju oziroma aktu pisanja, navdihu, pesnikovem odnosu do tradicije, pesniškem poklicu, literarnem življenju - položaju ustvarjalca v literarnem sistemu in širšem družbenozgodovinskem kontekstu, o poeziji oziroma (besedni) umetnosti nasploh, pesmi kot umetniškem delu, pesniškem jeziku, literarnih konvencijah in tudi refleksijo o branju ter pričakovanem bralčevem odzivu (prim. Weber 1971, 181; Juvan 1994, 278; 2000, 194-195; 2001, 46).

Metapoetski premislek ima lahko različne pojavne oblike: obsega celotno pesemsko besedilo in je njegov ključni konstitutivni element ali pa gre le za drobec, ki je umeščen med druge motive. Pomembno pripomore $\mathrm{k}$ razumevanju osebne poetike in vloge literarnega diskurza v širšem družbenozgodovinskem okviru, hkrati pa pesniku omogoča samoosmišljevanje pesniškega dejanja, samoutemeljevanje v literarnem sistemu in samoumeščanje poezije $\mathrm{v}$ širši družbeni kontekst. S stališč sistemske teorije je samorefleksija strategija, $s$ katero se sistem literature samoregulira in odziva "na idejne, vrednostne, politične, gospodarske in socialne spremembe» (Juvan 2001, 46).

Eva Müller-Zettelmann se $\mathrm{v}$ obravnavi metapoezije naslanja na spoznanja naratologije in kot estetski učinek lirične samorefleksije oziroma avtoreferencialnosti izpostavi deziluzijo (preizpraševanje razmerja med 
resničnostjo in fikcijo). ${ }^{1}$ Avtorica uvede klasifikacijo, ki razlikuje med primarnimi in sekundarnimi metaliričnimi pesmimi. Pri sekundarni metaliriki gre za tematsko obravnavo posameznih vidikov literarne komunikacije, medtem ko je za primarno metaliriko ključno, da osvetljuje svojo lastno literarnost, njena značilnost je nemožnost razločevanja med aktom (dejanjem) in objektom tekstualizacije, iz paradoksa neskončnih izmenjav v tem hierarhičnem odnosu pa izvira estetski učinek razblinjanja iluzije (2005, 132-137).

\section{Družbene okoliščine in literatura}

Položaj literature in vloga literarnega ustvarjalca se spreminjata skladno z družbenimi spremembami. Za uveljavitev literature kot »samostojnega in zapletenega družbenega podsistema« je pomembno obdobje romantike, ko literatura dobi »vlogo nadomestka za izgubljeno totaliteto religije«, umetnik pa postane "subjekt svobodne in neizčrpne imaginacije» (Juvan 2001, 44). Do romantičnega genija, ki je zaradi nasprotja med nedosegljivim idealom avtonomnosti in izvirnosti ter neizogibno vpetostjo v družbeni kontekst paradoksen, so vodile spremembe vloge avtorja od antičnega pevca - vidca, prek srednjeveškega avtorja, čigar "avtoriteta se opira na Boga ", in profesionalnega pisca, ki se pojavi z razvojem tiska in trga (Dović 2007, 20-28).

$\mathrm{V}$ 20. stoletju umetniki dobijo bolj avtonomen, vendar socialno bolj negotov položaj, saj se upirajo nastajajoči množični družbi, veri v napredek in iztrošeni, nepristni podedovani tradiciji. Po Adornovi teoriji avantgardne umetnosti je značilnost sodobne umetnosti poleg proizvodnje umetniških del tudi problematiziranje položaja umetnosti in umetnika $\mathrm{v}$ svetu (Vattimo 2004, 94). Resnejši krizi je bila »romantična ideologija « v smislu poveličevanja pesnikov in literature kot nosilke družbenih vrednot tako izpostavljena šele konec 20. stoletja (Juvan 2001, 68).

Spreminjanje položaja literature in literarnega ustvarjalca $\mathrm{v}$ širšem kontekstu se reflektira tudi v literarnih delih. ${ }^{2} \mathrm{~V}$ slovenski poeziji je sam-

1 Primerjaj pri Horstu Breuerju, ki, ki kot značilnost metaliterature izpostavi sklicevanje na umetniško-fikcijski pogoj. To ožjo definicijo metaliterature v nadaljevanju razširi z ugotovitvijo, da metapoezija obsega besedila, v katerih je samosklicevanje strukturna značilnost, prek katere na paradoksen način obravnavajo lasten poetični status, obenem pa tudi besedila, ki tematizirajo verzno umetnost in posebnosti pesniškega poklica $(2005,49-50)$.

2 Metapoetično stanje lirike je še posebej značilno prav za moderni in postmoderni čas (Breuer 2005, 49-51). 
opremislek pesniškega ustvarjanja in pesnika kot ustvarjajočega subjekta moč slediti vse od začetkov slovenskega umetnega pesništva (Juvan 1994) in nato romantične težnje po uveljavitvi avtonomije pesništva, izražene v Prešernovih avtotematskih pesmih (Juvan 2001).

Podobno kot je imela književnost za večino evropskih narodov v romantiki narodnobuditeljsko vlogo in pomembno mesto pri »oblikovanju nacionalnih držav«, je bil tudi proces slovenskega osamosvajanja v devetdesetih letih »odvisen prav od 'kulturnega kapitala slovenske literature' kot osrednjega toposa nacionalne identifikacije« (Virk 2008, 3-4). Primož Čučnik opozori, da v Sloveniji sicer ni "politične poezije, kot jo poznajo na Poljskem v osemdesetih«, so pa avtorji v devetdesetih javno politično nastopali (Krečič 2005, 13). Spremenjene družbeno-politične okoliščine po osamosvojitvi Slovenije in po vzpostavitvi demokratičnega političnega sistema ter pluralnosti misli v družbi tako spodbujajo premislek o (novi) vlogi pesnikov (literatov) in poezije (literature) v družbi. Poezija je namreč izgubila samoumevno upravičenost do obstoja, ki jo je kot »manifestacija svobode« imela v enopartijskem sistemu (Kos 2004, 195-197).

\section{Samorefleksija v poeziji Primoža Čučnika}

Primož Čučnik (prvenec Dve zimi, 1999) se uvršča v mlado slovensko poezijo, ${ }^{4}$ to je skupino pesnikov, ki je začela ustvarjati po letu 1990. Je uveljavljen in večkrat nagrajeni avtor.' Njegov pesniški opus obsega sedem samostojnih pesniških zbirk, piše kritike in eseje, je tudi urednik. Avtopoetskim premislekom namenja prostor tudi v intervjujih.

V Čučnikovi avtotematski poeziji, ki je najmočneje prisotna v prvih treh in zadnji zbirki, najdemo premisleke odnosa do lastnega poslanstva in poezije, refleksije intertekstualnih navezav ter razmerja med pesniškim navdihom in obrtniško veščino. Pogosta so razmišljanja o ustvarjalnem procesu in jeziku kot mediju pesniškega ustvarjanja. ${ }^{6}$ Značilnost Čučnikovega dojemanja poezije je povezanost z zvokom, glasbo.

Matevž Kos izpostavi, »da je bila slovenskost - če sploh - prežeta z duhom poezije toliko časa, dokler je bila dejanskost države hipotetična, [...] zadeva pesniškega imaginarija $(2004,203)$. Prešernovega sklada (2008), Jenkova nagrada (2011) in Veronikina nagrada (2012).

6 Jezik je pomemben element Čučnikovega razmišljanja o poeziji tudi v intervjujih. O »visokem jeziku« poezije pravi, da je »bilo treba sestopiti. Poezija se oplaja z najrazličnejšimi jeziki« $(2012,231)$. 
Poetološka tematika je prisotna tudi v povezavi $\mathrm{z}$ odzivom poezije na družbeno dogajanje. $\mathrm{V}$ navezavi s tem se odpira dilema, v kolikšni meri je poezija lahko družbeno dejavna in ali je s stališča pesnika to pomembno.? $\mathrm{O}$ »specifičnem pojmovanju avtorjeve pozicije v odnosu do družbe« v mlajši slovenski liriki je pisal M. Potocco (2010, 234). Ugotavlja, da lahko pri Čučniku in nekaterih drugih pesnikih mlajše generacije $\mathrm{v}$ »Zavračanju povezave avtorja in njegovega delovanja v družbenem polju« prepoznamo »boj za simbolni kapital « in - v primerjavi z modernistično težnjo po avtonomnosti literature - vzpostavljanje »avtonomnost[i] avtorja kot konkretnega akterja v družbenem polju«. Potocco hkrati opaža, da se v zadnjih letih pri Čučniku na primer v zbirki Delo in dom - pojavlja »nastavek v smer družbene kritičnosti« (2010, 235). Prav željo po večjem deležu angažirane literature in obenem previdnosti v delovanju angažiranih avtorjev je Čučnik izrazil tudi na okrogli mizi festivala Pranger (Krečič 2005, 13). ${ }^{8}$

\section{Odnos do poezije in poslanstva pesnika}

V prvencu Dve zimi (1999) se lirski subjekt ustvarjanja loteva entuziastično, čeprav se zaveda, da ga čakajo tako napori kot ustvarjalnega zaleta polni trenutki, kar antitetično izrazi z verzi: »ko bom prisiljen žgati glino / in lepiti razbiti vrč« nasproti »ko bom barval stene prostora, / meril in polnil, se napil / in spravljal v ravnovesje«. Subjekt je pripravljen tudi na odpoved, saj njegovi "precizni prsti [...] zase ne zahtevajo ničesar« v želji doseči edinstveno: »Biti dotik jezika / na nebu / nemih ust« (Mera, 25). Ustvarjanje je poslanstvo spregovoriti z jezikom v območju nemega, njegova vera $\mathrm{v}$ učinek je neizpodbitna. Pesem ima moč in pravico prebiti polje molka, ker je utemeljena $\mathrm{v}$ tradiciji in nenehni ponovljivosti: "Zgodba / neštetih pesmi se ponavlja«, ter usojenosti govorečega in sprejemajočega: »potem postane / usoda in nazadnje hladno / upanje«. Drugoosebni govor lirskega subjekta, splošnejši »ti«, odpira dialog z naslovnikom, bralcem in izraža, da je govorec pesmi lahko vsak in da je pesem vseprisotna v vsakem posamezniku: »Poveš jo pri odprtem oknu.« Pesem pa ni le vpisana kot usoda v posameznika in čas, ampak ima funkcijo, ki sega čez estetsko razsežnost, prodre v globino posameznika: „Najprej se dotakne kože, / potem zaskeli in nazadnje / rahlo peče« (Pesem, 47). Metafora stopnjevane bolečine vnaša po-

7 Čučnik razmišlja o možnosti »drugačnih angažiranosti, ožje družbenih, mikropolitičnih, osebnih» $(2012,245)$.

8 Prim. Potocco $(2010,235)$. 
men katarzičnosti, nečesa, kar spoznavno-etično pretrese posameznika v samem jedru.

Biti kot ustvarjalec medij poetičnega izraza pomeni sprejeti ambivalentnost občutenj, izraženih skozi antiteze: »Besede so muka in dar. Zmaga in poraz. / Edino in odveč.» Poezija ustvarjajočega posameznika spremeni, do skrajnosti izostri zaznavanje: »Poezija je iz mene naredila / pošast « in omogoči subjektu, da se razcepi, dobi dvojnika in začne sprejemati sebe samega in svojo resnico z zunanjega gledišča: »To je moje drugo življenje, prestopil sem samega / sebe«, kar pa omogoči skrajno zmožnost spoznanja: "Živeti pesniško povzema vsa razpoloženja «(Spoznanje, 67). Poezija je tisti način govora in spoznavanja resnice, ki lahko zaobseže celoto, vse sinhrono in diahrono prisotno: »Preprosto hočem biti zraven, ko se rojeva, / novo in novo, [...] Tako resnično je tako resnično!« (Pesem Ortonimu, 51-52).

Lirski subjekt se zaveda, da poezije ne more definirati z enoznačno trditvijo, zato o njej razmišlja v pogojniku: »Če je poezija zato, da smo si bliže, [...] Če je poezija zato, da postane rob življenja«. Poezija naj bi na eni strani zbliževala posameznike in na drugi razširjala obzorja, možnosti, do koder lahko seže (duhovni) pogled človeka, ker prek poezije "postavljamo vprašanja nebu, / zemlji in bogovom«(Ostanki dneva, 57).

Antitetično razumevanje bistva in smisla poezije ter njena zmožnost zaobseči vse nianse med skrajnostmi se nadaljuje v zbirki Ritem $v$ rôkah (2002), v kateri je poezija nekje med žalostjo in smehom, med besedo in tišino ter med sovraštvom in ljubeznijo. Pesem postane za lirski subjekt pribežališče, kjer v risu samosti lahko sreča samega sebe in se začne razpletati kot »majhna zagonetka«: »Ko ti nekaj ne pusti zaspati / je edini prostor v pesmi«. V tem izpraznjenem, irealnem prostoru se pokaže možnost relativizacije časa: »kraj za zdaj in vedno« $(\mathrm{Za}$ G., 50).

$\mathrm{V}$ Akordih (2004) razmislek o poslanstvu pesnika izhaja iz primerjave s filozofom. Pesem Zakaj nisem filozof (62-63) je nastala kot odgovor na recenzijo, ki je Čučniku očitala, da je njegova pesniška zbirka Ritem $v$ rôkah v primerjavi s poezijo O'Hare, s katero se Čučnikova poezija intertekstualno povezuje, abstraktno refleksivna in da je Čučnik v njej bolj filozof kot pesnik (Divjak 2002). Čučnik se je zato odzval v obliki citatne navezave na O'Harovo pesem Zakaj nisem slikar, s čimer je zavrnil vnaprejšnje vkalupljanje poezije, ki je dialog in ne primerjava $z$ drugim in jo je sam razumel kot nekaj večjega od sebe $(2002,156)$. V pesmi je razložen proces pisanja, ki je na meji razumsko doumljivega: »Besede me preganjajo. Popravljam. Ne razumem, kaj hočem povedati« in tematizirana želja ubesediti tudi nerazum- 
ljivo - na primer zavedanje niča. Vendar ima tudi poezija tako kot filozofski diskurz: »'Od PRAZNINE so ostale le natisnjene besede'«, omejitve. Avtoreferencialna izpostavitev »napišem POLNI STAVKI NIČA« ponazarja paradoks, da »niča« ni mogoče izgovoriti ali napisati, ker akt poimenovanja izhaja iz prisotnosti.

Od spoznanja, da poezija ne more poimenovati v celoti vsega, kar subjekt pretresa, v predzadnjih dveh pesniških zbirkah (Delo in dom, 2007; Kot dar, 2010) razmislek o poeziji postane humorno-ironično obarvan. Vprašanje "Ali še verjameš v poezijo? « je ironično opredeljeno kot »Dobro vprašanje.« $\mathrm{V}$ nadaljevanju sledi zavrnitev iskanja pragmatične vloge poezije: »Način za preživetje, ohranitev vrste, / družbeno spremembo ...? / Nič takšnega.« Kljub temu izpostavljeni glagol biti ne dopušča dvoma o možnosti in smislu njenega obstoja. Poezija je umeščena med konkretnimi »črkami« in »nebom « - je nekaj stvarnega, ki omogoča vpogled v presežno, ki sega čez posameznika tukaj in zdaj, $v$ transcendentno. V sklepu refleksijo o vlogi poezije prekine avtoreferencialna navezava na postopek lastnega pisanja, pomensko zoženega na povsem tehnično raven, celo zgolj na napako stroja, neodvisno od hotenj subjekta.

\section{. (Pika)}

Napaka na pravkar kupljenem ekranu.

Izpostavitev tehničnega postopka stopi $\mathrm{v}$ semantično napeto razmerje $\mathrm{z}$ retoričnim vprašanjem o umestitvi poetičnega ustvarjanja $\mathrm{v}$ polje duhovnega: "Sfera sanj? «(Kaj je poezija, 30, Delo in dom). ${ }^{9}$ Lirski subjekt se zaveda nezmožnosti enopomenske opredelitve poezije. ${ }^{10}$

Rdeča nit Mikada (2012) je povezanost poezije z igro in zvokom, vendar ne v smislu lahkotnosti, poenostavljanja, temveč predstavljata osnovni kompozicijski in spoznavni načeli. ${ }^{\text {II }} \mathrm{V}$ igri kot metafori za poezijo si sam, zato ni prostora za tekmovalnost, vrednosti posameznih enot (pesmi) pa

9 Avtoreferencialne navezave, kot je na primer opredelitev "Območje: Lirika» (Weimarska republika, po letu 1919, 45, Kot dar), izpostavljajo fikcijskost napisanega in učinkujejo v smeri deziluzije; po E. Müller-Zettelmann bi lahko te pasaže uvrstili v primarno metaliriko.

10 Prim. s pesmijo Navodila za uporabo (31, Delo in dom).

11 Pomen toposa glasbe v Čučnikovi poeziji odražajo že naslovi nekaterih zbirk (Ritem $v$ rôkah, Akordi). Motivi, povezani z glasbo, so pogosti tudi v navezavi na poetološko tematiko. Zvoki, ki jih srečuje subjekt, so dražljaji za ustvarjanje poezije, prek motiva ušesa pa je poudarjen pomen vključitve več čutil za pravo spoznanje, kar omogoča 
so relativne. Pesnik poudarja, da igro - poezijo - lahko razume vsak in da je najboljša (doseže svoj cilj) tedaj, kadar je brezkončna - fingira ali ciklično ponavljanje ali neomejeno nadaljevanje. V Eseju o ušesu na koncu pesniške zbirke pesnik na kompleksen, pa tudi humoren način opredeljuje poezijo in neizogibno povezanost lastne osebe s pesniškim ustvarjanjem: »Imeti ušesa in posluh, zato da bi živel pesniško, to mi je namenjeno.« (109) Poeziji priznava avtonomnost, neodvisnost od ustvarjajočega subjekta in ne pristaja na njeno zgolj mimetičnost: »Poezija je odrasla in ima svoja čustva [...] Ne verjamem, da je treba čustva iz življenja prepisovati v poezijo.« (109) Vrednost in pomen poezije vidi v njeni zmožnosti, da prek sinestetičnega dojemanja posamezniku omogoči zavedanje sveta izven razumsko dosegljivih meja: »Ekonomija poezije je izguba zavesti. Je dobiček zavedanja.«(113)

\section{Od navdiha do obrtniške veščine}

Ustvarjajoči pesniški subjekt v Dveh zimah priznava navdih in ustvarjanja poezije ne razume kot (le) priučeno veščino. Ustvarjalna moč ni absolutna, je ranljiva in tudi odsotna: »Zdaj ni več tistih pisem, juter in navdiha«. Subjekt pa ni božansko navdahnjen romantični pevec, temveč navdih odkriva v stvarnosti, ki ga obdaja: v vsakdanjih podobah življenja, spominih in naravi ter podobah mesta. Natančno opazovanje in moč pretanjenega spominjanja, ki subjekt vodita $\mathrm{v}$ ustvarjanje, povzročita njegovo drugačnost od drugih: "In razen mene, ki čakam pesem, vsi čakajo poletje« ter globlje, trpko zavedanje odtekanja časa, zato je subjekt »edini, ki presekan s časom šteje kope posušenih let« (Basina, 39). Vprašanje ustvarjalnih možnosti je vpeto $\mathrm{v}$ širšo eksistencialno negotovost. Razrešitev eksistencialne in ustvarjalne otrplosti pa pesniški subjekt vidi v srečanju $\mathrm{z}$ »drugim človekom «, čeprav s tem determiniranost s smrtjo ostaja (Ledena gora, 83).

Zavedanje časa prek cikličnega menjavanja letnih časov in raziskovanje možnosti, da pesem njegovo odtekanje ustavi, se zrcali v Prihodih zime, 2.: »Pesem je (pravi) trenutek, odločen, da ostane« (40, Ritem v rôkah). Odvisnost pesnjenja od zunanjega sveta in poetično odsevanje (mimesis) realnosti je ironičnemu podtonu izpostavljeno v Sonetih za neodgovorjene klice, 3.: »Le kako bi človek pisal, če bi se / preselil v Ljubljano? Mogoče kot dež, padajoč [...] Kot črnogledi pesniki, // ki

poezija. Glasba obenem ni le metafora poetičnega ustvarjanja, ampak je tudi širši eksistencialni simbol življenja. 
te zmeraj opominjajo, da bo treba umreti« (46). Lirski subjekt se upre temačnemu eksistencialnemu razpoloženju in modernistični pesniški tradiciji in za svoje ustvarjanje namesto stalnega premišljanja o neizbežnosti smrti $\mathrm{v}$ prizmi sprijaznjenja $\mathrm{z}$ neizbežnim izbere življenje $\mathrm{v}$ vsakodnevnih opravkih: »Preveč kaditi, popiti preveč / kave in vse do konca tragično kramljati s tabo.«

V pesniški zbirki Kot dar je navdihovanje ob cikličnih spremembah narave, $v$ katerih je vkodirano stalno gibanje, podvrženo ironiji. Pretirano navdušen opis prebujanja pomladi "nič s pomladjo se ne meri po lepoti« dobi zvrstno ambivalenten odgovor v grobi banalizaciji »skopneli kupi dreka, znani po svoji grdoti« (Zgodnja pomlad, Hopkins, 14). Odmik od romantično patetične vzhičenosti nad naravnimi procesi vodi v poudarjanje pomena ustvarjalčeve udeleženosti $\mathrm{v}$ aktualnih družbenih dogajanjih, pri čemer ne gre spregledati ironičnega podtona: »Kar razburljivo je bilo / opazovati demonstrantsko množico [...] Od tu bom sigurno odšel / s polnim jezikom podrobnosti«. Z metaforo ptiča, ki »nekako gnezdi v glavi / leti samo takrat, ko komu poje«, je pesnik opredeljen kot nekdo, ki lahko s ptičje perspektive (distance) govori o svetu, hkrati pa se z uporabo narekovajev distancira od »'večnih stvari'«, ki jih »čivka«. ${ }^{\text {I2 }}$ Pesem naj bo razumljiva, tukaj in zdaj (Da zaprem to mapo, 32). Pesniški subjekt podobe črpa iz avtentičnega življenja slehernikov, njihovemu govoru daje prostor $\mathrm{v}$ pesmih, s čimer dobijo značilnost večglasnosti. Subjekt se tudi zaveda, da je del moderne, tehnološke družbe, ki se je korenito (tudi vrednostno) preobrazila. Kot ustvarjalec se mora prilagoditi: »opazujem proizvode, vedoč, / da so jih naredile podobne roke kot moje / in stroji, podobni pisalnim strojem, / računalniki, podobni mojemu «. Pesnik in njegova tradicionalno duhovno privilegirana dejavnost postaneta del kapitalistične družbe: »Če sta mi bila, v kakršni koli meri, dana duša in talent, o tem ne vem ničesar. [...] Tako si mislim, ko se nasmiham / izza pulta svoje prodajalne« (Trgovina, 54) in »razumem, da sem tudi sam obrtnik« (Dobra zgradba, 56). Talent, izbranost v novem kontekstu nista več pomembna. Pisanje se ne odvija več le $\mathrm{v}$ »sferi sanj«, ampak tudi na računalniku - z rokami, ki delajo tudi vsa druga bolj ali manj praktična opravila.

12 Podoben učinek ima koncept dvojnika v Dveh zimah, ki subjektu omogoča distanco in avtorefleksivno introspekcijo: »Dvojnik, si samo privid jezika, / sestavljen le zato, da se učim / pomena besed?« (Dvojnik, 19). 


\section{Samorefleksija intertekstualnega dialoga}

Prepletenost ustvarjajočega subjekta $\mathrm{z}$ literaturo se kaže $\mathrm{v}$ motivu branja kot spodbude za pisanje, še posebej v zbirki Akordi.

Pomenska večplastnost Čučnikove poezije pa pogosto temelji na prepletenosti s citati in vključevanju različnih diskurzov tako iz literarnega polja kot tudi iz vsakdanje komunikacije: »pravi tvoj hitri odgovor [...] in to je čisto dovolj za napisat / tole pesem " (59, Ritem v rôkah). ${ }^{13}$ Prek intertekstualnega dialoga, ki je večkrat tudi eksplicitno izpostavljen s kazalkami, kot so naslovi, moti, posvetila, pesniški subjekt posreduje tudi metapoetične refleksije. Čučnikova poezija stopa v produktivno interakcijo še posebej z ameriško in poljsko pesniško tradicijo. Sam Čučnik pravi, da ga je ameriški pesnik O'Hara »naučil predvsem tega, kako pesem najde živ prostor med dvema osebama « $(2012,233)$. Čučnikov literarni dialog z O'Haro se kaže že v nekaterih temeljnih poetoloških usmeritvah, kot je produktivno povezovanje poezije $z$ glasbo in tudi vizualnim. ${ }^{14}$ Skupno je njuno navdihovanje nad pesniškimi imeni, kot je na primer Majakovski. ${ }^{\text {IS }}$

V Čučnikovi poeziji se prek citatnosti, dvogovora s pesniškimi glasovi, kot so na primer Ashbery, Majakovski, že omenjeni O'Hara, vzpostavlja večpomenskost besedil, živo interakcijo z drugimi besedili pa pesnik tudi tematizira kot eno pomembnih prvin pesniškega postopka in odnosa do pesniškega ustvarjanja. V Čučnikovih pesmih je zavestno tematizirano, da pesniški subjekt - avtor ni le prejemnik vpliva, ampak da dejavno vstopa v intertekstualna razmerja in se nanje odziva. Pesem Majakovski tako izraža naklonjenost, ampak sočasno tudi razdaljo subjekta do pesniškega predhodnika: »ker ljubim tvoj oblak / in se zaljubim v tvoj šal / ampak ne vate / klovna zgodovine« (39, Akordi).

V prvencu Dve zimi pesnik eksplicitno razkriva navdihovanje svojega pisanja pri pesnikih, kot sta Vallejo in Miłosz. ${ }^{16}$ Pesniški subjekt se z eksplicitno izpostavljenim citiranjem Miłosza izreka o svoji poetološki

13 Čučnik izpostavi, da pri pisanju želi najti izviren izraz, vendar da hkrati občuti vpetost v (jezikovne) vzorce tradicije (2012: 231).

14 Čučnik je prepoznaven po literarno-glasbenih nastopih in odpiranju prostora literarne umetnosti elementom drugih umetnosti, na primer vizualnim in zvočnim v Odi na manhatnski aveniji. Poseben primer prepletanja jezikovno-vizualnega sporočanja je tudi projekt Ljubezen je bojno polje, pri katerem je vzporedno z razstavo v galeriji Škuc (Čučnik, Kariž, Ožbolt 2005) nastala tudi knjiga (2006).

15 O O'Hari, njegovi povezanosti z drugimi umetnostmi in literarnimi spodbudami Čučnik piše v spremni besedi k izboru pesmi Srce v žepu (2002, 99-107).

16 Citata iz njune poezije stojita kot moto na začetku zbirke. 
poziciji: "In še to kar pravi Miłosz: Who serves best doesn't always understand." in »Največ pesmi ne razumem. [...] Samo iz ljubezni je možna pesem« (Pismo, 27). Citat potrjuje stališče, da je pesem diskurz, v katerem ni možno in niti ne nujno popolno razumevanje. Pomembno za pesniško ustvarjanje pa je, da izhaja iz odnosa do drugega, do sveta. $S$ poezijo perujskega pesnika Valleja se pred lirskim subjektom razprejo nianse trpečega občutenja sveta, zato si zanje dovoli odpreti tudi svoje ustvarjanje: »Kadar koli srečam Valleja, se skorja mojega / pisanja vrne v zibelko, tisto največ, kar sem preživel [...] in vrne se moja patetična žalost«. Vrnitev k izvoru, h koreninam razpre eksistencialno tesnobo zavedanja končnosti, $\mathrm{v}$ risu katere je ujeto tudi ustvarjalno dejanje: »potem / lahko razumem, kaj pomeni poznati konec, // vseskoz pisati v senci točnega sla (Srečanje, 9). Vzporednost eksistencialne pretresenosti in razsežnosti dilem ustvarjanja je izražena tudi v pesmi Edvardu Kocbeku: »Vedno začenjamo / znova. Samo jecljamo še« (77).

Pesniški subjekt najde identifikacijo glede razumevanja postopka pisanja kot truda $\mathrm{v}$ intertekstualnem navezovanju na Jesihove verze iz zbirke Soneti, ko pravi, »da si ves preljubi dan grizem nohte / in se mučim $\mathrm{z}$ eno samo vrstico « (Musica vulgaris, 6o, Akordi). Tudi Jesihov pesniški subjekt izpoveduje pomanjkanje navdiha in ustvarjalni mrk, obe pesmi pa prežema blaga humorna ironija, ki preizprašuje možnosti poiskati in poimenovati vir poetičnega navdiha ter potrjuje, da je pesniški postopek vedno tudi trdo delo in interakcija $\mathrm{z}$ drugim in drugimi besedili.

Srečevanje Čučnikove poezije $\mathrm{z}$ ameriško megalomanskostjo in občutje bližine s poljsko poezijo zasledimo v pesmi Amerika (10, Ritem $v$ rôkah): »Amerika, / pol toliko mi nisi dala kot daješ poljskim pesnikom.» Eksplicitno je tematiziran intenziven odnos med pesniškim subjektom in vsem, kar se ga je dotaknilo v Ameriki, vendar ostaja samozavesten v svoji poziciji, zavedajoč se, da so odnosi vedno dvosmerni: »Nisi mi dala veliko in še to ti vračam."

Intertekstualno sklicevanje na O'Haro, izpostavljeno že $\mathrm{v}$ povezavi z literarno polemiko Zakaj nisem filozof, je tudi pesem Hotel Transilvanija (Nova okna), kar kaže že istoimenski naslov. Čučnik prek navezovanja odgovarjanja - na O'Harovo pesem, ki ima obliko dialoga prvoosebnega pesniškega subjekta $\mathrm{z}$ drugoosebnim "you «, tematizira medbesedilno povezanost množinskega subjekta $\mathrm{z}$ drugimi besedili: »česar se spomnimo, ko smo / bili starejši ali mlajši, [...] bilo je črnilo / mračnih črk, nismo vedeli, ali sanjamo« (63). Znotraj medbesedilnega dialoga, »v katerem je izbi- 
ra branj za vsakogar«, je čas relativiziran. Pesniški subjekt prek spletanja intertekstualnih vezi vpeljuje večpomenskost svoje refleksije o življenju, bližini z drugim, preseganju časa: »ampak odbitih v ogledalih, / kjer se vidi, da ne tkemo sanj in nismo / nesmrtni« (66) in želji po dosegi estetskega: »Tu je vse v čakanju / na lepoto« (65).

Ashbery s svojimi verzi je izhodišče za odkrivanje pesniškega postopka - ustvarjanja -, ki je znova umeščeno v območje sanj, predstav. Pesniški subjekt fingira spomin (sanje), ki ni njegov pravi spomin, saj izhaja iz intertekstualne navezave - citatnega dialoga - s pesmijo Ashberyja The Instruction Manual. Podoba Priročnika za sanje, kot je naslovljena Čučnikova pesem, lahko simbolizira pesmi, ki pesnika spodbudijo za njegovo lastno ustvarjanje: »Ponujajo se sanje in razblinjajo. [...] Zdaj bom izstopil in vrnil se bom k priročniku, ki me je pripravil sanjariti o tramvaju v Ljubljani« (17, Delo in dom). Vendar pisanje pesmi ne more biti nikoli zgolj tehnično nizanje citatov, naslanjanje na vplive, ustvarjanje na podlagi vnaprej pripravljenih navodil, priročnikov, ampak je živa interakcija, vedno tudi v polju imaginarnega, sanjskega in ne docela razumljivega.

V zbirki Kot dar tradicija ni tematizirana (le) kot vir navdihujoče interakcije, ampak subjekt eksplicitno izpostavi tudi željo po njenem preoblikovanju, kar čuti kot svojo odgovornost: "Mogoče ponoviti isto pesem, // ampak na nov način, preden se dobrave zmračijo / in ne bomo več našli nazaj« (Pastoralne skrivalnice, 22). Motiv ponavljanja že znanega pesnik podčrta s hkratno intertekstualno navezavo na pesem Josipa Murna Ko dobrave se mrače. Tematiziranemu občutju pritiska pa sledi subjektova odločitev za kreativni spopad s tradicijo, ples, ki je odraz kreacije, igre, energije in vere v svoje početje: »To je pritisk, / ljuba duša / lets dance« (Ars Poetica 2007, 71, Mikado). Humorno-ironično je ubesedeno tudi razhajanje s tradicijo modernistov (Proti modernistom, 96), kjer prek motiva ušesa lirski subjekt izrazi svojo neodvisnost in prehajanje v ustvarjalno zrelost, ki si poišče svoj način pristopanja do sveta - sinestetično dojemanje. ${ }^{17}$ $\mathrm{S}$ pogumnim izražanjem lastnega pesniškega kreda si poišče svoje mesto $\mathrm{v}$ literarnem polju in se samoumešča v nizu tradicije. Poleg soočenja in dialoga s tradicijo hkrati na več mestih v sproščenem slogu ubeseduje tudi svojo umeščenost v generacijski krog pesniških kolegov: »Škrjanec na čiku, Podlogar na čaju« (Kredo 2, 80). 


\section{Poezija - družba}

V prvencu si pesniški subjekt - ustvarjalec - zada za nalogo biti popisovalec, vendar $\mathrm{v}$ tej zbirki prednjačijo motivi in podobe iz narave, subjektovo intimno odzivanje nanje ter osebne čustvene prelomnice. V naslednjih dveh zbirkah se njegov fokus usmeri tudi v družbeno stanje. ${ }^{18}$ Posreduje kritičen pogled na sočasno potrošniško družbo, $\mathrm{v}$ kateri so $\mathrm{v}$ prednosti glasnejši in slepo lojalni oblastnim strukturam in tradicionalnim avtoritetam, ki narekujejo življenja ljudem in jim odrekajo svobodo misli. Pesniški subjekt razmišlja, da bi se lahko tudi sam skril v množico, saj si ne želi slave in bi bilo to zanj lažje. Vendar kljub prevladi neumnosti, zanikanju tisočletne kulture naše civilizacije, uklanjanju množic banalnostim kapitalizma, odpovedi svobodi sam čuti zavezo, da se upre: "v tvoji nabiti glavi / odmevajo preslišani glasovi« (Zidovi, 8-9, Ritem v rôkah). Vztraja v govorjenju, ker posoja glas tistim, ki niso slišani. Pesniški subjekt se prepoznava kot nosilec vrednot svobode, neodvisnega mišljenja, neuklanjanja avtoritetam in materializmu. ${ }^{19}$

Akordi izpostavljajo problematiko nasilja, ki je vkodirano v ne-nasilje, gre za dve plati iste pojavnosti, zato se zdi popolna odstranitev nasilja nemogoča. Ker gre za prepletenost, je distanciranje posameznika od sovraštva neiskreno, dvolično dejanje: »Sovražiš usta, ki sovražijo?« Vprašanje: »Kdo jo [puško] bo prvi vrgel. / Vojak, pesnik ali derviš.« izgubi svojo vprašalno funkcijo in postane trditev, ki sugerira neizbirnost, vnaprejšnjo določenost: "Ne jezik ne molitev ne ustavita, / od zmeraj tu kot eno rasteta / nasilje, ne-nasilje!« (Puška v koruzi, 53). Pa vendar prevladujoče razpoloženje ni obup. Poezija ostaja dejanje, ki se upira vdanosti v družbo nasilja, poziva $\mathrm{k}$ neobsojanju in neapatičnosti.

Pesmi, ki poetološko tematiko povezujejo $\mathrm{z}$ odzivom na aktualno družbeno stanje, je v pesniški zbirki Kot dar še več. Pesem Moje hortenzije (26) je premislek razmerja med jezikom, narodom, vrednotami (svobodo) in družbeno realnostjo. Lirski subjekt pod vprašaj postavlja koncepte (na

18 Čučnik v esejističnem razmisleku pravi, da se je umetnik zaradi zapletenosti stvarnosti usmeril v svoj notranji svet in eksperimentiranje $\mathrm{z}$ jezikom. Vendar sam zagovarja "težnjo po razumljivosti in preprostosti« in vztraja, da naj poezija podaja "celostno človeško doživljanje«, čeprav bi bilo verjeti v neposreden vpliv poezije na resničnost naivno $(2008,19-22,28)$.

19 Pesem Iščemo varuha, kje je (35, Delo in dom) prek intertekstualne navezave na znan Zajčev verz »Za vse boš plačal« pokaže, da so tisti, ki se ne uklonijo in ostanejo zvesti svojim vrednotam ter idealom, podvrženi nerazumevanju zbirokratizirane politično-družbene situacije. 
primer narod, tudi jezik kot »skupno zadevo«), ki so zgolj konstrukti, oblikovani skozi zgodovino, in ki jim brez premisleka verjamemo: "Narod je univerzalna množica posameznikov [...] Ali pa je to nacija. Ali pa je to država.« Kritična ost je usmerjena proti vzorcem mišljenja, ki nam jih vsiljujejo drugi, naši naivnosti in nasedanju konstruktom oblikovalcev splošnega javnega mnenja: »Kaj govorim, to je obdobje novega optimizma.« Osrednji tok ironično intonirane refleksije pa $\mathrm{v}$ slogu refrenskega odpeva prekinja naslovna podoba hortenzij: »Vsak pri sebi ve, kaj so njegove hortenzije. [...] Lep jezik zagatno zaliva [...] moje hortenzije.« Hortenzije lahko predstavljajo ideal, smisel človekovega življenja. »Hortenzije« pesniškega subjekta ostajajo povezane $\mathrm{z}$ jezikom in možnostjo estetskega jezikovnega izraza. ${ }^{20}$

V ciklu Zamisel reda $v$ zapuščeni kitajski restavraciji (Kot dar) avtoreferencialno ozaveščanje povoda za pisanje izpostavlja aktualno problematiko: »Tole sem začel pisati iz usmiljenja [...] Kot strela z jasnega sem pomislil / na družine priseljencev." (67) Pesnik poskuša s svojim ustvarjanjem vzpostaviti red, ki ga ni in za katerega se zaveda, da bo mogoč le na ravni literarnega. Gre le za »zamisel«, zato »[t]a red moraš zaključiti / z nasmeškom, in to je več, kot lahko / jeziki povejo« (75).

\section{Zaključek}

S samorefleksivnimi podobami se pesnik skladno $\mathrm{z}$ novimi okoliščinami samopozicionira v literarnem sistemu - v krogu sodobnikov in tradicije in s preizpraševanjem smisla in pomena poezije samoutemeljuje pesniško ustvarjanje v sodobni družbi.

Avtotematske podobe razkrivajo, da poezija ostaja za subjekt neulovljiva v smislu enoznačne definicije, vendar pa subjekt spreminja do skrajnosti in mu omogoči posebno spoznanje resnice, srečanje $s$ svetom in $s$ samim sabo. Kljub temu da subjekt odkriva tudi omejitve jezika in poezije, ne dopušča dvoma v smisel njenega obstoja. Poezija je nekaj stvarnega,

20 Refleksija o jeziku je prisotna na več mestih. Pesnik se zaveda odvisnosti pesniškega ustvarjanja od jezika: "Pesmi so iz besed" (19:47, 70, Ritem v rôkah). Subjekt utemeljuje sebe in svet prek jezika, določen je z njim, saj mu omogoča stik s svetom oziroma prek njega svet dojema in hkrati tvori. Kasneje jezik postavi na prvo mesto, izstopa tendenca po jeziku, ki bi bil neodvisen od subjekta in bi lahko govoril čez subjektovo posameznost. Osvobojen jezik je nosilec resnice. Ima pa tudi omejitve ne more poimenovati in s tem utemeljiti transcendence: »In beseda Bog se vzdiguje v nekaj, / kar v resnici je, ampak ne morejo je izgovoriti / usta" (Hvala za sonce, 58, Nova okna). Kljub temu pa vera v besedo - poezijo - ostane neomajna: »Kar koli se zgodi, imaš besedo" (Pozna pomlad, 16, Kot dar). 
ki omogoča vpogled v presežno. Pesnik ni od realnosti distanciran, božansko navdahnjen pevec, ampak išče navdih v življenju okrog sebe. Zaveda se, da je pisanje tudi veščina, in sprejema vpetost $\mathrm{v}$ realnost sodobne družbe. Svojo posebnost vidi v sposobnosti pretanjenega opažanja. Povezava poezije z glasbo, z zvokom oziroma slušnim se nazadnje izkristalizira kot pravi način spoznavanja in pesniškega ustvarjanja. Prek samorefleksije je podan tudi subjektov odnos do pesniške tradicije, ki prehaja od navdiha, interaktivnega povezovanja do želje preseganja vpliva in nazadnje v odločitev za samozavestno kreativno sodelovanje $\mathrm{z}$ njo.

Bolj kot razmislek odgovornosti poezije do tradicionalnega koncepta naroda je prisotno spraševanje o vlogi poezije in lastnega vztrajanja $\mathrm{v}$ ustvarjanju v kontekstu globalnih problemov sodobne družbe. Pesniški subjekt posreduje kritičen pogled na potrošniško družbo. Pomen svojega početja prepoznava $\mathrm{v}$ izražanju vrednot svobode, neodvisnega mišljenja in upora materializmu. Kot ustvarjalec daje glas neslišanim.

\section{Viri}

Čučnik, Primož. 1999. Dve zimi. Ljubljana: Aleph.

Čučnik, Primož. 2002. Ritem v rôkah. Aleph. Ljubljana: Center za slovensko književnost.

Čučnik, Primož, Gregor Podlogar in Žiga Kariž. 2003. Oda na manhatnski aveniji. Velika šerpa. Ljubljana: LUD Šerpa.

Čučnik, Primož. 2004. Akordi in druge pesmi. Žepna šerpa. Ljubljana: LUD Šerpa.

Čučnik, Primož. 2005. Nova okna. Prišleki. Ljubljana: LUD Literatura.

Čučnik, Primož. 2006. Sekira v medu: prebrane in druge pesmi: 1995-2005. Klasična šerpa. Ljubljana: LUD Šerpa.

Čučnik, Primož, Žiga Kariž in Alen Ožbolt. 20o6. Ljubezen je bojno polje: knjiga umetnikov = Love is a battlefield: artists book. Velika šerpa. Ljubljana: LUD Šerpa.

Čučnik, Primož. 2007. Delo in dom. Prišleki. Ljubljana: LUD Literatura.

Čučnik, Primož. 2010. Kot dar. Klasična Šerpa. Ljubljana: LUD Šerpa.

Čučnik, Primož. 2012. Mikado: (1-5-5-15-15). Beletrina. Ljubljana: Študentska založba.

Čučnik, Primož. 2015. Trilogija. Prišleki. Ljubljana: LUD Literatura. 


\section{Literatura}

Breuer, Horst. 2005. »ohn Keats' Ode 'To Autumn' als Metapoesie«. V SelfReflexivity in Literature, ur. Werner Huber, Martin Middeke in Hubert Zapf, 49-64. Würzburg: Königshausen \& Neumann.

Čučnik, Primož. 2002. »Zakaj nisem filozof Literatura 14 (136): 155-158.

Čučnik, Primož. 2008. Spati na krilu: eseji, kritike, fragmenti. Ljubljana: LUD Literatura.

Čučnik, Primož. 2012. "Zame se pesem vedno dogaja vsaj med dvema pesmima«. Spraševal je Igor Divjak. Literatura 24 (250): 228-246.

Divjak, Igor. 2002. »Intelektualne sheme namesto atmosfere«. Literatura 14 (135): 138-144.

Divjak, Igor. 2016. »Tretji Čučnikov obrat: Primož Čučnik: Trilogija«. Delo, 30. 8. 2016. 15.

Dović, Marijan. 2007. Slovenski pisatelj: razvoj vloge literarnega proizvajalca $v$ slovenskem literarnem sistemu. Ljubljana: Založba ZRC, ZRC SAZU.

Huber, Werner, Martin Middeke in Hubert Zapf, ur. 2005. Self-Reflexivity in Literature. Text \& Theorie. Würzburg: Königshausen \& Neumann.

Juvan, Marko. 1994. "Slovenski Parnasi in Eliziji: literarni kanon in njegove uprizoritve«. V Individualni in generacijski ustvarjalni ritmi $v$ slovenskem jeziku, književnosti in kulturi: ob 1o-letnici smrti Marje Boršnikove (Obdobja, 14), ur. Marko Juvan in Tomaž Sajovic, 277-315. Ljubljana: Znanstveni inštitut Filozofske fakultete.

Juvan, Marko. 20oo. Vezi besedila: študije o slovenski književnosti in medbesedilnosti. Novi pristopi. Ljubljana: Literarno-umetniško društvo Literatura.

Juvan, Marko. 200oa. Intertekstualnost. Literarni leksikon, 45. Ljubljana: DZS.

Juvan, Marko. 2001. »Prešernova in Puškinova poezija o poeziji«. V F. Prešeren - A. S. Puškin = F. Prešern - A. S. Puškin: $($ ob 2oo-letnici njunega rojstva $)=$ ( $k$ 2oo-letiju ih roždenija), ur. Miha Javornik, 43-71. Ljubljana: Znanstveni inštitut Filozofske fakultete.

Kos, Matevž. 1996. Prevzetnost in pristranost: literarni spisi. Novi pristopi. Ljubljana: Literarno-umetniško društvo Literatura.

Kos, Matevž, izbral. 2004. Mi se vrnemo zvečer: antologija mlade slovenske poezije: 1990-2003. Ljubljana: Študentska založba.

Krečič, Jela. 2005. »Politični pranger«. Delo, 13. 7. 2005. 13.

Müller-Zettelmann, Eva. 2005. »'A Frenzied Oscillation': Auto-Reflexivity in the Lyric«. V Theory into poetry: new approaches to the lyric, ur. Eva 
Müller-Zettelmann in Margarete Rubik, 125-145. Amsterdam; New York: Rodopi.

Novak Popov, Irena. 2003. Sprehodi po slovenski poeziji. Maribor: Litera.

O'Hara, Frank. 2002. Srce v žepu, izbor in prevod Tone Škrjanec in Primož Čučnik. Ljubljana: ŠKUC.

Obermaier, Sabine. 1999. "Möglichkeiten und Grenzen der Interpretation von 'Dichtung über Dichtung' als Schlüssel für eine Poetik mittelhochdeutscher Lyrik«. V Mittelalterliche Lyrik: Probleme der Poetik, ur. Thomas Cramer in Ingrid Kasten, 11-32. Berlin: Erich Schmidt.

Oraić Tolić, Dubravka in Viktor Žmegač, ur. 1993. Intertekstualnost \& autoreferencijalnost. Zagreb: Zavod za znanost o književnosti Filozofskoga fakulteta Sveučilišta u Zagrebu.

Paternu, Boris. 1999. Od ekspresionizma do postmoderne: študije o slovenskem pesništvu in jeziku. Ljubljana: Slovenska matica.

Potocco, Marcello. 2010. »Raba podobja in avtonomnost pesniške pozicije (nekaj opazk ob mlajši slovenski liriki)«. V Sodobna slovenska književnost (1980-2010) (Obdobja, 29), ur. Alojzija Zupan Sosič, 233-238. Ljubljana: Center za slovenščino kot drugi/tuji jezik pri Oddelku za slovenistiko Filozofske fakultete.

Vattimo, Giani. 2004. Filozofska karta 20. stoletja: tehnika in eksistenca. Ljubljana: Sophia.

Virk, Tomo. 2008. "Zakaj je književnost pomembna?« V Književnost v izobraževanju - cilji, vsebine, metode (Obdobja, 25), ur. Boža Krakar Vogel, 3-13. Ljubljana: Center za slovenščino kot drugi/tuji jezik pri Oddelku za slovenistiko Filozofske fakultete. 



\section{Slovenska ulična poezija po letu i99I in vpliv nestrpnosti}

Jernej Kusterle

Podiplomska šola ZRC SAZU, Literatura v kontekstu, Ljubljana

Postgraduate school ZRC SAZU, Literature in Context, Ljubljana

jernej.kusterle@gmail.com

Prispevek bo v prvem delu na kratko predstavil teoretično in zgodovinsko ozadje (slovenske) ulične poezije. Teoretični pristop bo ponudil glavne točke, ki utemeljujejo, zakaj se rap, kot hibridna struktura glasbe in besedila, lahko obravnava v okviru literarne vede kot ulična poezija, zgodovinski pristop pa bo nakazal enega izmed razlogov za nastanek ulične poezije $\mathrm{v}$ slovenskem prostoru, kar pomeni prelomnico na področjih glasbene in pesniške umetnosti. Drugi del bo analitičen, v njem bo v okviru konkretnih primerov slovenske ulične poezije obravnavana tema (ne) strpnosti. Ta bo nastopila $\mathrm{v}$ dveh vlogah: nestrpnost in poziv $\mathrm{k}$ strpnosti.

Ključne besede: ulična poezija, rap, literarna teorija, literarna zgodovina, nestrpnost

\section{Slovenian Street Poetry after 1991 and Influence of Intolerance}

This article will first try to present the theoretical and historical background of (Slovenian) street poetry. A theoretical approach will highlights the principal points, which justify why rap, as a hybrid structure of music and lyrics, should be discussed within literary science as street poetry and a historical approach will point out one of the reasons why the street poetry formed in Slovenia marks a turning point in the fields of music and poetry. 
Second part of this article will be analytical. It will deal with concrete examples of Slovenian street poetry, where themes of patience/impatience occur. The theme performs in two roles: intolerance and an appeal to tolerance.

Key words: street poetry, rap, literary theory, literary history, intolerance

\section{Uvod}

Ulična poezija je bila dolgo asociirana zgolj z glasbeno umetnostjo in je javnosti bolj znana pod zvrstnim imenom rap, ki kot kratica pomeni Rhythm and Poetry (slov. ritem in poezija) ali Rhythmically Accentuated Poetry (slov. ritmično poudarjena poezija). Utemeljitev rabe besedne zveze znotraj literarne vede poleg razvezane kratične oblike temelji še na pomenu obeh sestavin, pri čemer se ulica pomensko veže na načrtno speljano pot s pločnikom $\mathrm{v}$ mestu, poezija pa s tistim historičnim pomenom starogrškega izraza póiēsis, ki je predstavljal pesniško umetnost, povezano z glasbo in plesom, kar se še danes kaže v uglasbitvah tradicionalne poezije.

Razlika med pojmi: ulična, poulična in urbana poezija je $\mathrm{v}$ njihovi konotaciji in dejanski rabi. Medtem ko je besedna zveza urbana poezija že dalj časa $\mathrm{v}$ rabi za tisto obliko tradicionalne poezije, ki vsebuje elemente urbanega okolja, ima besedna zveza poulična poezija negativno konotacijsko vrednost, saj čutimo tvorbo kot analogijo tvorbi besedne zveze poulično dekle (pocestnica/vlačuga/prostitutka). Zaradi tega se je za rap že pred časom pojavil sinonim ulična poezija, ki je utemeljen tudi $\mathrm{z}$ dejansko rabo $\mathrm{v}$ besedilih slovenskih uličnih pesnikov.

Znotraj teorije ulične poezije prihaja do delitve na ožjo in širšo opredelitev, pri čemer ožja ulično poezijo razume zgolj kot zapisano besedilo, izolirano od glasbenega konteksta, za kar se je v anglosaškem svetu oblikoval izraz raps, ki ima ustreznico $\mathrm{v}$ rap lyrics (slov. rap besedila), širša pa jo razume kot sklop poezije in glasbe, besedila in glasbene podlage, govora in instrumentalne spremljave, $\mathrm{v}$ katerih prihaja do medumetnostnega povezovanja, ki temelji na vzajemnem odnosu poezija : glasba. Širša opredelitev ulične poezije pa upošteva tudi performative, persono, glasovno interpretacijo in modo (po Kusterle 2016).

\section{Nestrpnost v ulični poeziji}

Nestrpnost $\mathrm{v}$ ulični poeziji izvira iz ameriškega okolja, od koder ta oblika poezije izhaja. V ameriškem kontekstu je potrebna refleksija o družbeno- 
-političnih dejavnikih ameriške družbe od 17. stoletja do 70. let 20. stoletja, ko so se temnopolti začeli izražati skozi ulično poezijo.

Izvor napetosti datira v 17. stoletje, v čas kolonialne Amerike, ko so temnopolti predstavljali sužnje in služinčad. Za sužnje so bili uporniška dejanja in znanje, ki so ga pridobivali iz zgodb in pesmi, bistvo njihove kulture, gradniki zgodovinske zavesti, nudili so občutek pripadnosti skupnosti ter moralni sistem, ki je določal obstoj dobrega in zla. Zaradi splošne segregacije, prepovedi opismenjevanja, izobraževanja in napredka znotraj ameriške družbe je prišlo do uporov in akcij za odpravo suženjstva. Šele v začetku 20. let 20. stoletja so Afro-Američani odkrili možnost oblikovanja lastne identitete v takratnem sovražnem okolju. Oblikovala se je t. i. harlemska renesansa, gibanje, v okviru katerega je prišlo do prvih poskusov temnopoltih, da bi se uveljavili v družbi. Ker belci temnopoltim niso dovolili izobraževanja in uveljavljanja, so se temnopolti posvetili pisanju, glasbi in socialni kritiki, s čimer označujemo prve poskuse temnopoltih umetnikov in intelektualcev, da bi se označili s pojmom »moderno «. ${ }^{1} \mathrm{H}$. A. Baker, Jr. (1989) piše, da so temnopolti umetnost prevzeli kot sredstvo upanja, področje možnega uspeha in kot edino možnost za napredovanje v družbi, saj tu barva kože ni bila pomembna. Leta 1963 so temnopolti v Washingtonu organizirali masovni shod za enakopravnost, na katerem je več kot 250.0oo poslušalcev poslušalo zgodovinski govor Imam sanje (angl. I Have a Dream) enega izmed najboljših oratorjev sodobnega časa, Martina Luthra Kinga mlajšega. $\mathrm{V}$ njem je dejal, da sanja o tem, da bodo njegovi otroci nekoč obravnavani v skladu z njihovim karakterjem in ne $\mathrm{z}$ barvo kože. Manifest, ki je temnopolte še bolj združil, je prinesel nov val nasilja nad temnopoltim prebivalstvom. Ob koncu leta je $\mathrm{v}$ atentatu umrl ameriški predsednik J. F. Kennedy, simpatizer gibanja za državljanske pravice. Novi ameriški predsednik L. B. Johnson si je uzakonjenje državljanskih pravic postavil za prioriteto. S pomočjo Akta o državljanskih pravicah iz leta 1964 je prepovedal segregacijo v vseh javnih prostorih ter pri zveznem šolskem financiranju in financiranju institucij ter programov. Belci so zaradi tega okrepili nasilje in februarja 1965 je bil ubit Malcolm X, aprila 1968 pa še Martin Luther King mlajši. 1966. se je oblikovalo temnopolto gibanje Črni panter (angl. Black Panther Party), ki je kasneje vplivalo na enega izmed najvplivnejših predstavnikov ameriške zahodnoobalne rap glasbe, Tupaca

Po navedbah H. A. Bakerja mlajšega se je prvi dogodek, ki je vplival na nastanek in razvoj harlemske renesanse, zgodil 18. septembra 1895, ko se je začel t. i. afroameriški modernizem. Na ta dan je imel Booker T. Washington govor o vlogi črnskega prebivalstva $\mathrm{v}$ ameriški družbi. 
Amaruja Shakurja. To in druga podobna gibanja je FBI, ki je delil mnenje o državljanskih pravicah s Ku Klux Klanom, leta 1967 označil za črnske sovražne skupine, zato so jih prepovedali. Položaj temnopoltega srednjega razreda se je sčasoma izboljšal, a najnižji sloji prebivalstva so še vedno živeli v diskriminaciji, nasilju in bedi. 6o. in 7o. leta, čas druge črnske renesanse, je zaznamovalo novo gibanje za samodeterminacijo temnopoltih, t. i. Black Power movement, v okviru katerega se je oblikovala tudi kulturno-umetniška smer, gibanje črnskih umetnosti (angl. Black Arts movement). Obe sta v začetku 7o. let ${ }^{2}$ vplivali na nastanek hip-hop gibanja, ${ }^{3}$ katerega temelje je postavil Afrika Bambaataa, ko je ustanovil skupino Zulu Nation.

Pod njenim vodstvom so se ulične tolpe preoblikovale v ekipe, ki so za medsebojno obračunavanje namesto hladnega orožja uporabljale glasbo, ples ali besedila. Hip-hop je postal simbol temnopoltih, njihovega nestrinjanja z oblastjo, zakoni, politiko itd. Postal je kritika slabih družbenih razmer in življenja v getih. (Kusterle 2014, 97)

Hip-hop kot skupek različnih umetnosti predstavlja večumetnostno področje $\mathrm{z}$ dolgo in pestro zgodovino. Za moje proučevanje je najpomembnejša literarna umetnost, in sicer tisti del, ki nastopa kot input in output subkulture, imenovane rap ${ }^{4}$ oziroma ulične poezije.

\section{Definicija (ne)strpnosti}

Vesna Leskošek pravi, da »[s]lovar pojmov, ki ga je izdelala mednarodna organizacija United for Intercultural Action, besedo toleranca (slovenimo jo kot strpnost) pojasni kot spoštovanje, sprejemanje in cenjenje bogate raznolikosti svetovnih kultur, načinov izražanja in oblik človečnosti, humanosti« $(2005,9)$. Za nestrpnost kot nasprotje strpnosti pa zapiše, da »[p]omeni nespoštovanje prepričanj in življenjskih praks drugih ljudi. Nestrpnost pomeni, da so nekateri ljudje obravnavani drugače zaradi svojih religioznih prepričanj, njihove seksualnosti, ali celo zaradi drugačne obleke ali las« (prav tam).

Pomembno je, da pojem nestrpnost obravnavamo v antagonističnem razmerju s pojmom strpnost. Poglejmo si dve definiciji strpnosti:

2 Po nekaterih pričevanjih naj bi bil natančen datum 11. 11. 1973.

3 Jezikovno strukturo hip-hop gibanje uporabljam po Reilandu Rabaki (2012), ki pravi, da novo gibanje temelji na predhodnih političnih in družbenih gibanjih temnopoltih v Ameriki. ranje. 
Strpnost je moč razumeti na več načinov. Lahko jo razumemo kot vrednoto notranje širine posameznika ali družbe, temelječo na avtonomiji in odgovornosti do soljudi. Lahko jo razumemo tudi kot spoštovanje človečnosti, kot zavest nedotakljivosti tistega temeljnega dostojanstva, ki ga zasluži vsako človeško bitje že samo s tem, da je na svetu in je s tem osmišljeno. (Rošker 2010, 137)

Koncept strpnosti, kakršen je v veljavi danes, [temelji] na strukturi razmerja med posamezniki in njihovo državo. Njegova teoretska podlaga je evropski koncept humanizma, ki temelji na predpostavki homo homini lupus, katere etične komponente so zakoličene $\mathrm{z}$ aksiomom svetosti človeškega življenja, ki mora biti v vsaki skupnosti zaščiteno (nedotakljivost telesa in duha). (Rošker 2010, 142)

(Ne)strpnost je družbeno-individualni sistem (ne)sprejemanja in (ne) spoštovanja drugačnosti na vseh ravneh (npr. verska, rasna, spolna idr.) družbeno-individualnega obstoja. Za ubesedenje nestrpnosti se uporablja instrument, ki je določen tako v slovenski Ustavi kot v Kazenskem zakon$\mathrm{iku}, \mathrm{tj}$. sovražni govor. O njem "govorimo [...] ko gre za izražanje mnenj in idej, ki so po svoji naravi ksenofobični, diskriminatorni, rasistični in naperjeni predvsem zoper razne manjšine (etnične, verske, kulturne) in zajema tako govorno, pisno kot nebesedno (parade, insignije, simboli, ipd.) komunikacijo.« (Varuh človekovih pravic 2006, splet) Sovražni govor je lahko obravnavan tudi kot "podžigajoč jezik, pogosto žaljiv in posmehovalen, usmerjen k posamezniku ali skupini« (Červ idr. 2012, 151), pri čemer je lahko poziv $k$ nasilju impliciten ali ekspliciten.

Eden ključnih elementov za prepoznavanje sovražnega govora je njegov namen, tj. človeka ponižati, prestrašiti, poslabšati njegov družbeni položaj, spodbuditi nasilje, prikazati ga kot tretjerazredno necivilizirano bitje idr. glede na rasne, etnične, spolne, religiozne, nacionalne in telesne izvore ter značilnosti manjšin. Namen sovražnega govora se uresničuje s pomočjo namerno izbranih jezikovnih sredstev. (Campos Ferreira idr. 2012, 204)

\section{Začetki nestrpnosti v slovenski ulični poeziji}

Čeprav lahko prve poskuse rapa v Sloveniji datiramo v letu 1981, ko sta nepeti govor v svojih komadih uporabila Jani Kovačič in Neca Falk, in 1988, ko so se s skupino KUD Koseski in njihovim studijskim komadom Kekec rap začele prve resnejše pojavitve rap glasbe v slovenskem prostoru, je bilo 
za slovensko rap glasbo prelomno šele leto 1994, ko sta izšla prva domača rap albuma, Leva scena (Ali En) in Včasih smučam hit (KoširRapTeam).

Po osamosvojitvi Slovenije je komunizem nasledila demokracija, ki je omogočila svobodo govora in tiska, vendar je cenzura neuradno še vsaj desetletje ostala v slovenskem prostoru. To se je najočitneje kazalo v rap glasbi, ki je imela zaradi neevfemistične leksike in barbarističnega izrazas največ posegov v besedila. Najodmevnejšo cenzuro je doživel Ali En, ko je izdal Levo sceno, na kateri je objavil komad ${ }^{6}$ Plestenjak. $^{7}$ Gre za diss ${ }^{8}$ na Jana Plestenjaka, ki se je na začetku glasbene kariere preizkusil v rap glasbi. $\mathrm{Na}$ festivalu Pop delavnica (1993) je za komad Naj stvari so tri prejel nagrado za najmodernejšo glasbo. Ali En v odzivu poseže na področje nestrpnosti, ko med drugim zapiše:

Sm bil v Ameriki, študiru sm jazz. / Lažeš! Kurac si fafu in ga dubu v ass. [...] Sodeluješ z Alenko in ljudmi, kot je Oto, / a ne vidš osu, da jim delaš sramoto. / Mama slike prodaja, naj rajš tebe proda. / Sj najbrž bi te, ampak kdo hoče psa. (1994)

Omenjenemu primeru sledita še vsaj dva, in sicer: Leva scena ter Stremetzsky. Levo sceno Ali En začne z verzi:

Vsem se bom zameril, ampak resnica boli, / na domači glasbeni sceni prav vse smrdi. / Končno zdej je čas, da nekdo pove resnico pravo, / nekdo ki ma jajca in misli s svojo glavo. / Vse so sama znanstva, vse so same veze, / levih bendov je milijon, skor vsi total brezveze. $(1994,1)$

$S$ tem na kritičen način odpre še danes aktualno problematiko. Medtem ko večino tedanjih glasbenih estradnikov obravnava neposredno (npr.: Simona Weiss, Faraoni, Pop Design, Laibach, Jure Košir), do dveh iz-

»Na sleng in žargon imajo velik vpliv barbarizmi, tj. nižja občevalna leksika, ki jo ima izobraženec za hudo izrazno neskrbnost, a je nevtralna v določeni družbeni plasti. Barbarizmi sami po sebi niso sleng, vendar jih tisti, ki govorijo v slengu, radi rabijo namesto nevtralnih inačic, pač zato, ker so stilno zaznamovani in neformalni.« (Gjurin 1974, 68-69)

6 V rap glasbi se namesto izraza pesem uporablja pojem komad. Gre za pomenskorazločevalno lastnost, ki loči uglasbeno obliko od napisane oblike besedila.

7 Leva scena je izšla na avdio kaseti in CD-ju, a se komad Plestenjak nahaja le na avdio kaseti, da bi v primeru tožbe iz prodaje umaknili le avdio kasete, ne pa tudi CD-jev.

8 Diss je komad, katerega namen je nasprotnika čim bolj prizadeti. Samostalnik »diss « izhaja iz glagola »to dislike» (slov. ne marati) in samostalnika »disrespect» (slov. nespoštovanje). 
bere posredni pristop (Tomaž Domicelj, Jan Plestenjak), zaradi česar mora poslušalec/bralec za razumevanje poznati kontekst. Tako za Domiclja zapiše:

En muskonter prav izstopa, za mene je debil, / ljudje pa mu pravijo slovenskega naroda sin. / Svoj največji hit je naredu že pred dvajsetimi leti, / a še zmeraj ga špila in si misli »vsi so kmeti«. / V resnici je kmet on, naj se vrže čez balkon, / če bo sreča, zlom si vrat, ti zafukan idiot moron. (1994, 1)

\section{Za Plestenjaka pa:}

Po moje sami nesposobneži, vsak misli, da je as. / Eden od njih pravi, da je jazz muzikant, / v resnici pa je mlad nesposoben fant, / ima denarja preveč, je razvajen sin od svoje mame, / zdaj lahko on pri meni se uči, kdo ima sposobnosti prave. (Prav tam)

Ali En drugo kitico zaključi z verzoma: "Za tako sceno k' bi človek samo bruhnu, / jaz besede mam tri: hvala, fuck you!« (Prav tam)

Komad Stremetzsky po eni izmed razlag temelji na resničnem primeru, saj naj bi bil Stremetzsky psevdonim za ljubljanskega učitelja, ki so mu bili všeč otroci. (Jizah 2009) Ali En kot eno izmed tem kritično izpostavi pedofilijo:

Lej na parkirišču avto se maje / v njem se ena mejhna bejba s štirimi dol daje / sej bi stopu zraven, za en krog bi si jo sposodu / jo vrgu na kolena in odzadi jo nabodu / sploh neb'lo problema za tako malo šalo / a porivat majhne otroke ni okusno, ni tapravo. $(1994,2)$

V drugi kitici pa se osredotoči na kritiko odraslih žensk.

\begin{tabular}{|c|c|}
\hline PORAŠČENOST & TELESNA TEŽA \\
\hline $\begin{array}{l}\text { As' že kdaj pofuku pičko k' ma obrito pizdo / } \\
\text { nobena stvar ni lepša od mehke obrite pizde / če } \\
\text { pička ni kosmata večji je žur / če ma pizdo svojo } \\
\text { obrito bejba je cool / se mi enkrat je zgodilo da } \\
\text { bla je vsa kosmata / se mi je zdelo kot da fukam } \\
\text { njenga brata. }(1994,2)\end{array}$ & $\begin{array}{l}\text { Ene so sam' okrogle, druge pa debele / pejte } \\
\text { mal na fitnes moje drage Špele / vse okoli vas } \\
\text { je grdo in mem / vsak tip k' za vami gleda sig- } \\
\text { urno je lesen / dejte se no zrihtat da kurac nam } \\
\text { bo vstal / če ne niti na cesti vas nobeden nau po- } \\
\text { bral. }(1994,2)\end{array}$ \\
\hline
\end{tabular}

\section{Vrste nestrpnosti v slovenski ulični poeziji}

V 14. členu Ustave Republike Slovenije piše, da so »[v] Sloveniji [...] vsakomur zagotovljene enake človekove pravice in temeljne svoboščine, ne gle- 
de na narodnost, raso, spol, jezik, vero, politično ali drugo prepričanje, gmotno stanje, rojstvo, izobrazbo, družbeni položaj, invalidnost ali katerokoli drugo osebno okoliščino.«

Nestrpnost se $\mathrm{v}$ slovenski ulični poeziji pojavlja $\mathrm{v}$ različnih oblikah (besedna in nebesedna nestrpnost). V prispevku obravnavam le nekatere vrste besedne nestrpnosti, in sicer: nestrpnost med spoloma, nestrpnost $\mathrm{v}$ povezavi $\mathrm{z}$ vero in spolno usmeritvijo ter narodnostno in regionalno nestrpnost.

\section{Nestrpnost med biološkima spoloma}

Med moškim in ženskim biološkim spolom že več desetletij prihaja do medsebojnih obračunavanj, ki so posledica odnosnega razmerja med feminizmom in maskulizmom. Kot piše Josephine Donovan (1989, xi), se je feminizem kot gibanje za pravice in enakopravnost žensk v družbi razvil na podlagi moškega zatiranja žensk. Njegov namen je $\mathrm{v}$ revolucionarni aktivnosti kot praksi, ki bi pripomogla k izboljšanju družbene situacije (prav tam, xii). Cheri Register navede izjavo Ellen Morgan, ki pravi, da bi »[f] eministična kritika [...] morala [...] spodbujati umetnost, ki izhaja iz pristne ženske izkušnje in ki ni filtrirana $\mathrm{z}$ moško perspektivo ali skrčena do te mere, da bi ustrezala moškim standardom« (prav tam, 19).

Ideja o enakopravnem položaju bioloških spolov se je kmalu izrodila. Prišlo je do radikalizacije feminizma, kjer so moški označeni kot sovražniki in tirani (Kegan Gardiner 2002, 3). Gre za usmeritev v t. i. spolni preobrat, ki vzpodbuja ženske, da zaničujejo moške, kot so to prej počeli oni njim. Mandelker $(1994,54)$ pravi, da so se radikalni feministi v 70 . letih 2o. stoletja povezali v skupino The Feminist, ki se je zavzemala za odpravo zakonske zveze, družine in heteroseksualnih spolnih odnosov. Ta skupina naj bi lezbičnost postavila na čelo feminizma, saj naj bi bilo »biti lezbijka« moralno, odnos ženske z moškim pa sramoten. Vendar so »bolne, perverzne kvalitete tako stvar moške narave kakor ženske, proti-moški seksizem pa je enako žaljiv, škodljiv in nevzdržen kakor proti-ženski seksizem« (prav tam, 53). Kot antagonizem feminizmu se je oblikoval maskulizem, ki je sprva temeljil na restavraciji moške nadvlade nad ženskami in izničenju napredka feminističnega gibanja (Gardiner 2002, 2), kasneje pa se je pod pritiski feminizma na določenih področjih razvil v boj za pravice moških. Judith Kegan Gardiner $(2002,3)$ pravi, da naj bi bila ena izmed teženj feminizma razspoljenje oziroma izbris spola, kar naj bi omogočilo obravnavo posameznika na podlagi vrste. To je vzpodbudilo moške, da so smeši- 
li feministične analize o neugodnem položaju žensk v družbi, navajali so, da so žrtve oni, in pripisovali tradicionalne moške značilnosti ter privilegije hormonom, evoluciji ali logiki. Maskulizem je zagovarjal moško nadvlado, feminističnim napadom pa pripisoval krivdo za splošne psihološke in socialne probleme ter izgubo statusa moških v družbi (prav tam, 4). Tako kot se je znotraj feministične teorije oblikoval ekstrem radikalnega feminizma, se je znotraj maskulistične teorije pojavil ekstrem mizoginije, tj. moško sovraštvo do žensk.

Družbenemu spopadu med biološkima spoloma se ni uspela ogniti niti ulična poezija. Yvonne Bynoe $(2006,262)$ pravi, da je mizoginija sicer znotraj ulične poezije resda najbolj izpostavljena, vzrok za to je v njeni pragmatičnosti, se je pa v 7o. in 8o. letih 20. stoletja v obliki predstavljanja ženske kot spolnega objekta pojavljala v besedilih, videospotih ter na ovitkih glasbenih albumov rock glasbenikov. Problematične so predvsem oznake (npr. kurba, prasica, pička itd.), s katerimi avtorji (tudi avtorice) označujejo ženske, ki moškim odvzemajo spoštovanje in čast ter ženske dehumanizirajo do stopnje predmeta oziroma spolnega objekta. Po drugi strani pa se pri avtoricah kaže problematičnost $\mathrm{v}$ narativnem prikazu fetišizacije odnosov med biološkima spoloma, kjer moški, da bi ugodili ženskam, postanejo razvrednoteni ter ponižani.

\section{RADIKALNI FEMINIZEM}

en masira mi ramena, drug frizira mi pramena / tretji čaka zamenjavo, k nova je izmena [...] k vroče je, pihaj mi s pahljačo / k žejna sm, prinesi mi pijačo / in k lačna sm, jedla bi jedačo / in $\mathrm{k}$ pade noč, ti boš moj mačo. (Katana 2010, 10)

\section{MIZOGINIJA}

za tebe ni ljubezni, dam ti šamar / po riti, ko sva sama, jutri pa se že več ne poznama / v čem je problem, lej jo, da si kurba, vsi vejo / take pičke, kot si ti, se pofukajo in grejo / cipa goniš se okol kot psica, ko si ulita. (Delicti 2003, 7)

\section{Nestrpnost $\mathrm{v}$ povezavi $\mathrm{z}$ vero in spolno usmeritvijo}

Drago Kos meni, »da sta načelni multikulturalizem in dejanska stopnja še sprejete (tolerirane) verske (kulturne) raznovrstnosti tudi v razvitih liberalnih demokracijah precej vsaksebi. Vsi bogovi so dobrodošli, ampak nekateri nekoliko manj« $(2012,90)$. Ob tem navaja, da je že Locke sredi 17. stoletja razmišljal, »da je toleranca do tistih, ki se $\mathrm{v}$ zadevah religije razlikujejo od drugih, v tolikšnem soglasju s Kristusovim evangelijem in tudi s pristnim razumom človeštva, da se zdi pošastno, kako slepi so lahko ljudje za njeno nujnost in prednost, ko pa sta vendarle tako očitni« (prav tam). Vendar se odnos do problematike skozi stoletja ni pretirano spremenil, saj lahko še danes sledimo na eni strani spoštovanju in sprejemanju, na drugi stra- 
ni pa nespoštovanju in zavračanju različnih religij. Ob tem sodobna družba omogoča selektivno verovanje (verovanje v boga, ne pa tudi v institucije in predstavnike institucij, ki predstavljajo vero) ter ateizem, ki v javnost plasirata verski kriticizem.

Pr verouku sm jo zmer dobu okol ušesa / zarad tega, ker mi ni blo nikdar do seksa [...] vi v zameno rabte dnar, vam za folk ni mar, / isto sranje džamije, cerkve, ista stvar, / jst sm isku boga, pa ga pr vas nism najdu, / vaš bog mi ni pomagu takrat, ko sm padu. / ista banda kot vlada. [...] V Vatikanu ne vidm vere, ampak križe kljukaste. (Izić 2015, 3)

Z vero povezana problemska vprašanja odpira tudi homoseksualnost, pojem, ki naj bi se prvič pojavil leta $1869 \mathrm{v}$ Angliji. »V dvajsetih letih devetnajstega stoletja se začne uporabljati v vsakdanji govorici in se ga povezuje s pojmom perverznost. Danes se [...] [ga] loči od pojma perverznost, saj homoseksualno nagnjenje ne predstavlja nujno spolne zasvojenosti« (Štuhec 2004, 481). Avtor v nadaljevanju piše, da je homoseksualnost »Judovsko krščanska civilizacija [...] zavračala in obsojala. To zavračanje je vplivalo na javno mnenje, na zakonodajo in na odnos znanosti do tega pojava« (prav tam, 484). Čeprav se v Svetem pismu na več mestih omenja stališče do homoseksualnosti, sta morda najbolj eksplicitna odlomka iz Tretje Mojzesove knjige, ki se glasita: »Ne smeš ležati z moškim, kakor se leži z žensko; to bi bila gnusoba« (SSP 2000, 3Mz 18,22) in pa: „Če kdo leži z moškim, kakor se leži z žensko, sta oba storila gnusobo; naj bosta usmrčena; njuna kri pade nanju « (SSP 2000, 3Mz 20,13). Zametke homofobije torej lahko najdemo že znotraj religije, od koder transgresivno prehaja na posvetna področja. Nataša Velikonja pravi:

Če je razsvetljenstvo v začetku 19. stoletja še podpiralo dekriminalizacijo homoseksualnosti, pa so se zakoni proti homoseksualnim dejanjem proti koncu stoletja zaostrili, svojega opravičila niso več iskali v religiozni občutljivosti, temveč $\mathrm{v}$ populacijskih politikah, v škodi, ki naj bi jo seksualne perverzije povzročile narodovemu zdravju. Tako kot je predhodna kriminaliziranja homoseksualnosti upravičevala cerkev, je to sedaj počela medicina, podobe bolezni, izprijenosti in degeneriranosti pa so bile izrisane kot protiutež nacionalnih simbolov o možatosti. (1999, 138)

Danes Ustava Republike Slovenije posamezniku omogoča, da si v skladu z lastnimi željami, prepričanji, nagnjenji in samoopredelitvijo sam izbere svojo vero in spolno usmeritev. Ne glede na izbiro so vsi posamezni- 
ki znotraj družbe enakopravni in enakovredni. Vendar kljub Ustavi RS, Kazenskemu zakoniku in drugim (tudi evropskim) dokumentom, ki predpisujejo enakopraven in enakovreden status vseh ljudi, se na ravni vseh družbenih razredov in odnosov (formalni : neformalni) pojavlja kršenje teh predpisov. Pri tem tudi slovenska ulična poezija ni izjema. Tako lahko pri Iziću najdemo še en primer verske nestrpnosti, »Kdo prav, da nism old school, da le fejk je / v osnovni šoli sva še z Jezusom zbirala cveke« (2015, 9), pri Ezy-G-ju pa primer homofobije, »Vsi drugačni, vsi enakopravni, kaj je to? / Pedrov pač ne morem, zato pa naj odjebejo« (v Dandrough 1996, 5).

\section{Narodnostna in regionalna nestrpnost}

Narodnostna in regionalna nestrpnost sta obravnavani skupaj, ker sta v samem bistvu enaki. Narodnostna nestrpnost je opredeljena kot nestrpnost do naroda (narodov), ki ni enak narodu, kateremu pripada tvorec narodnostne nestrpnosti. Regionalna nestrpnost je podobna, saj je opredeljena kot nestrpnost do prebivalca (prebivalcev) regije, ki ni tista, kateri pripada tvorec regionalne nestrpnosti.

\section{Regionalna nestrpnost}

Tendenca o lokalni pripadnosti je bila pri nas prisotna vsaj že v 18. stoletju, ko smo imeli Slovenci dve različici slovenskega knjižnega jezika, osrednjeslovenski knjižni jezik ali kranjščino in vzhodno slovenski prekmurski knjižni jezik. Kljub temu »Trubarjeva in Küzmičeva slovenščina nista bili sprejemljivi za celotni slovenski jezikovni prostor; delovali sta »lokalno«, tj. osrednjeslovensko kranjsko in vzhodnoslovensko prekmursko« (Jesenšek 2008, 2009, 207). Kasneje so medpokrajinske spore sprožali in se nanje odzivali npr.: športne navijaške ekipe, subkulturna gibanja in druge marginalne skupine. $\mathrm{V}$ slovenski rap glasbi je dogodkov, ki so vzrok za medlokalne ali medsoseske spore, kar nekaj. Eden izmed prvih in najodmevnejših v slovenskem kulturnem prostoru se je zgodil leta 2000, ko je Klemen Klemen izdal svoj debitantski album Trnow stajl, na katerega je uvrstil komad Trnow I/The Neralić Story: »Sovražim Maribor in Viole, sovražim celo Pohorje, / in zdaj gremo s sekiro v roki, poklali bomo Štajerce« (Klemen 2000, 5). Na Mladininem portalu beremo, da so bili verzi prepisani »z bežigrajskega stadiona« (TŠ 2001), vendar intertekstualnost in nadaljevanje besedila »[a]mpak to ni komad, da bom jest tko pel, / ampak izi, da bom lah ritm ujel« (Klemen 2000, 5), nista omilila negativnega učinka, ki 
ga je komad imel na poslušalce. Mariborska navijaška skupina Viole je raperju "priporočila, da naj ne hodi prek Trojan« (TŠ 2001). Športno in navijaško rivalstvo je tako prestopilo meje in Klemen Klemen kar nekaj časa ni smel nastopati v Mariboru in njegovi okolici. Tri leta kasneje je na svojem drugem samostojnem albumu Hipnoza v komadu Slovenija zapisal:

Nazaj na ulco, tm, k jest stojim. / Cel življenje mam že željo, da se za ljudstvo borim. / Ampak kako? Štajerci me sovražjo zato, / k sm za nih napisu bed komad, da navijam za Lublano. / Ne vidjo, da sm jest en takih l'di, / k se bori za vse skp, da bi vsi naprej pršli. (Klemen 2003, 4)

\section{Narod nostna nestrpnost}

Od konca druge svetovne vojne do leta 1960 se je »v Slovenijo priselilo 1270 ljudi letno" (Josipovič 2006, 244), vendar je bil v obdobju med 1954 in 1960 delež tistih, ki so se odselili, večji od števila priseljencev. Sredi 6o. let se je prvič zgodilo, da se je več ljudi priselilo kot odselilo, a je bil ta pojav do konca 6o. let končan. Josipovič pravi, da je bilo v tem času mogoče zaznati »obrise prvih priselitvenih tokov« (prav tam, 145), ko je število priseljencev naraslo na 2530 letno. Kljub temu Slovenija »do sedemdesetih let ni bila niti posebej interesantna niti pomemben cilj za priseljevanje iz drugih republik« (prav tam, 207). Sredi 70. let se je delež priseljencev začel povečevati, »vrh pa je dosegel med letoma 1975 in 1980, ko so presežki dosegali tudi 8000 prebivalcev na leto « (prav tam, 132). To se je zgodilo zato, ker so bila sedemdeseta in začetek osemdesetih let »leta intenzivnejše industrializacije drugih predelov nekdanje SFRJ, predvsem Bosne in Hercegovine in ožje Srbije« (prav tam, 197). Vzroki za migracije niso bili zgolj ekonomski, ampak vsaj še politični, kar se je kazalo v procesu »spreminjanja monoetnične strukture Slovenije v smeri jugoslavizacije, kar pa ni uspelo« (prav tam, 230), in v dejstvu, da »si večina predvsem Muslimanov standarda sploh ni izboljšala, temveč je padla v še slabši ekonomski položaj« (prav tam, 230). V 80. letih je bil delež priseljevanja še vedno višji od odseljevanja, vendar so bile številke manjše kot v prejšnjem obdobju. »V osemdesetih letih se dotok migrantov sprva še nadaljuje, do devetdesetih pa skoraj povsem usahne« (prav tam, 245).

Josipovič pravi, da je bilo pri popisu iz leta 2002 mogoče zaznati krizo, ki je bila posledica prikrite asimilacije in krize etničnega opredeljevanja, pogojena pa je bila »tudi s slabim odnosom države do različnih problematik priseljenega prebivalstva, ki je odrinjeno na družbeni rob, k takemu položaju 
pa dodatno prispevajo tudi stereotipne predstave v slovenski javnosti« (prav tam, 251). Tako družbeno stanje je vodilo v formiranje radikalnejših skupin, med katerimi sta bili v devetdesetih letih druga in tretja generacija skinov, ki sta stopnjevali fašistično ideologijo, in raznih antipriseljenskih akcij, kot je bila npr. leta 1999 pojavitev slovenske računalniške igre Antičefur ${ }_{3} D$ (predelava kultne računalniške igre Duke Nukem 3 D), kjer je igralec v vlogi kranjskega Janeza Slovenijo očiščeval »čefurske nadloge« (Samaluk 2008, 40).

Vsi ti dejavniki so priseljence vzpodbudili k participaciji v kulturi, ki je bila zanje v danih okoliščinah najustreznejša, tj. hip-hopu. Leta 1999 je Ali En izrazil svojo družbeno identiteto: »Mt je Slovenka in fotr je od dol, / vseeno oba si mislta, da sm čist nor $(1999,3)$. Ulični pesniki v svojih besedilih opozarjajo na narodnostno nestrpnost, saj pogosto tudi sami pripadajo drugim narodnostim, zaradi česar so bili v preteklosti že segregirani:

»enim je na bad zato ker pišem se na ić js« (Ghet 2012, 1),

»In tvoj fotr me preprosto nima rad / zarad tega, ker sm oranžn + Hrvat« (Izić 2012, 15),

»V osnovki ožigosan ker sm čudne spise pisou / od učitlou zabitih sam zabite stvari sm slišou / biu dostrkrat čudn gledan ker sam drgač sm se pisou« (Radić 2009, 2).

Kot zadnji bo izpostavljen primer, ki poleg omembe narodnostne nestrpnosti izraža tudi poziv k strpnosti do drugačnih, »Me majo za čefurja, ma boli me kurac sm ponosn sine / da sm iz te družine in da nosim ta priimek [...] zato sm dans, tuki js še en bosanc / nemorm ven iz svoje kože lejga ni me sram / priznam, da sem južnjak brat / sam diham isti zrak, ko ti / tk da ne mi srat, ker sma ista kri« (Nemir 2012, 17).

\section{Pozivi k strpnosti}

Zaradi stopnjevane nestrpnosti v poosamosvojitveni slovenski družbi so avtorji ulične poezije svojo prepoznavnost izkoristili za poziv k strpnosti. Leta 2002 sta Murat in Jose izdala album $V$ besedi je moč, v katerega sta uvrstila komad Od ljudi za ljudi. Sodelovala sta s pevcem Siddharte, Tomijem

9 Pri računalniški igri Antičefur $3 \mathrm{D}$ so bile igralcem na voljo štiri različne sobe: Čefurji raus, Čas dela za nas, Razčefurjenje in AČ anarhija. Predvsem prva je za literarnega zgodovinarja zanimiva, saj je poimenovana tako kot Vojnovićev roman iz leta 2008 , torej bi naslov lahko razumeli kot protest proti igri, ki odkrito spodbuja nacionalizem. 
Megličem, in tako poskrbela, da je sporočilo slišala širša skupina ljudi. Jose, ki je sicer temnopolt, v komadu zapiše:

Kaj je s tem svetom, da je tko razdeljen, / kao, če nisi nš, pazi se, ker boš tepen. / Zakaj je važn, iz kje si al pa kako se pišeš, / kao, če nam to ni všeč, je bolj, da jo takoj pobrišeš. / Pejd domov, go home al pa še kej druzga loh slišš / od ljudi, k misljo, da so več vredni k ti. (V Murat \& Jose 2002, 8)

Proti koncu prve kitice pa še: »Vem, kaj govorim, tuki rojen, tuki živim / tuki vzgojen, slovenske matere $\sin «$ (prav tam). Tudi Murat v besedilu izrazi svoj odklonilni odnos do nestrpnosti,

Preveč negativnosti povsod okol mene / k pogledam ljudi drug prot drugmu nastrojene / politična, verska in rasna nestrpnost / sovraštvo, hinavščina in zahrbtnost / preveč se nosjo, za najbolše se majo / izkažeš jim spoštovanje, pa ti vrnt ga ne znajo. (Prav tam)

Vendar to ni edini primer poziva k strpnosti. Leta 2011 je Trkaj v sodelovanju s pevko Blažko posnel komad Nevidni. Posvetil ga je vsem, ki so drugačni in jih ljudje zaradi tega gledajo na drugačen način. Trkaj je prevzel vlogo posameznika, ki ga življenjske okoliščine naredijo drugačnega, zaradi česar ljudje spremenijo svoj odnos do njega. Z verzi je opozoril in skušal ozavestiti poslušalce/bralce, da lahko vsakdo kadarkoli in kjerkoli znotraj določenih okoliščin postane drugačen. Leto kasneje je sledil naslednji Trkajev poskus ozaveščenja ljudi. V sodelovanju s pevcem Adamom Velićem je za komad Razbijte stereotipe 10. maja 2012 na ljubljanskih ulicah posnel videospot. Posebnost projekta je v tem, da je bil posnet v dvajsetih minutah, in sicer med izvedbo »flashmoba«, v katerem so sodelovali naključni mimoidoči. Sporočilo besedila je bilo tako še jasnejše. Trkaj zapiše:

Če ti kj je zmankal, pol je zihr bil cigan, a ne? / Če kadim travo: kriminalc in narkoman - res je! / Če mam mal več kil, sm vreden malo manj, / in če sm musliman, pol nardil bo najbrž: Baamm! [...] Če mam dosti dnarja, pol sm zihr tudi snob, / ker sm druge barve, morm stran it od tod, / pršu sm iz zapora in se bom vrnu kmalu not, / da bolše rime pišem, ker sm padu iz šole, IDIOT! [...] Nemci nacisti, belci vsi isti, / bejba ti maš bulimijo, $\mathrm{k}$ si na modni pisti [...] mladi neumni naivni Slovenci, / pohlevni in mili, duhovniki le pedofili [...] ženske so kurbe, moški so le prasci, / lez- 
bike so čudne pa so gayi prenašalci, / čefurji ničvredni, starejši nepomembni. / Dvign špegle gor! Kaj smo vam naredli?« (2013, 9)

\section{Zaključek}

V prispevku je zaradi pomanjkanja prostora izpuščenih precej za proučevanje zanimivih primerov nestrpnosti, med katerimi sta bila v slovenskem prostoru dva zelo odmevna. Prvi je nadaljeval napetost med Mariborom in Ljubljano (Emkej proti Kurto A.J.), ki se je leta 2000 začela s Klemenom Klemenom, drugi pa je sprožil spor med obalnimi in ljubljanskimi uličnimi pesniki (Vauks in Alyo : Challe Salle, Adam Velić, DaKru, Shorti, Trkaj, Doša).

Vse dogajanje, ki se giblje okoli t. i. lokalpatriotizma, asociira na skrajni primer nestrpnosti iz polpretekle zgodovine, ki je zaznamoval svetovno družbo. V Ameriki se je proti sredini 9o. let »umetno« sprožil spor med vzhodno in zahodno obalo, ki sta ju predstavljala tedaj najpopularnejša ulična pesnika Notorious B.I.G. Biggie in Tupac Amaru Shakur. Ko je leta 1994 Tupac zapuščal prostore Quad Recording Studios v New Yorku, so ga neznanci ustrelili in oropali. Napad je preživel, zanj pa je v komadu Hit 'Em Up obtožil Biggija, pred incidentom dobrega in tesnega prijatelja. Kmalu je v javnost prišel Biggijev odgovor v komadu Who Shot Ya? Založbi Death Row Records in Bad Boy Records sta skupaj z mediji spor stopnjevali do točke, da so se v revijalnem tisku pojavljali naslovi o vojni med vzhodno in zahodno obalo, kar je septembra 1996 pripeljalo do streljanja, v katerem je bil ubit Tupac. Vendar ni bil edina žrtev. Šest mesecev kasneje, marca 1997, je bil v strelskem obračunu ubit tudi Biggie.

\section{Viri in literatura}

Baker, Houston A., Jr. 1989. Modernism and the Harlem renaissance. Chicago in London: The University of Chicago Press.

Bynoe, Yvonne. 2006. Encyclopedia of rap and hip hop culture. London: Greenwood press.

Compos, Ferreira, Petra Košič, Noemi Mavrič, Nina Mihalič. 2012. »Kriteriji za prepoznavanje sovražnega govora $v$ jeziku: študija primera«. V Teorija in praksa 49/1. 204-215.

Červ, Gaja, in Monika Kalin Golob. 2012. "Sovražni govor kot tip vrednotenja: jezikoslovni vidiki«. Teorija in praksa 49/1: 149-170. 
Dandrough. 1996. »Iz zibelke v grob«. Ko pride Bog. Zgoščenka. Slovenija: Conan. 5 .

Delicti, Corpus. 2003. »Kurbnhouse«. [neznani album]. Zgoščenka. Velenje: Samozaložba. 7 .

Donovan, Josephine. 1989. »Introduction to the Second Edition: Radical Feminist Criticism«. V Feminist Literary Criticism; Explorations in Theory (druga izdaja), ur. Josephine Donovan, ix-xxi. ZDA: The University Press of Kentucky.

En, Ali. 1994. »Leva scena«. Leva scena. Zgoščenka. Ljubljana: Založba Prodok/ Mačji disk. 1 .

En, Ali. 1994. »Plestenjak«. Leva scena. Avdio kaseta. Ljubljana: Založba Prodok/Mačji disk.

En, Ali. 1994. „Stremetzsky«. Leva scena. Zgoščenka. Ljubljana: Založba Prodok/Mačji disk. 2.

En, Ali. 1999. »Who is the real Kekec?«. Smetana za frende. Ljubljana: Založba Nika. 3.

Gardiner, Judith Kegan. 2002. »Introduction«. V Masculinity Studies \& Feminist Theory; New Directions, ur. Judith Kegan Gardiner, 1-29. New York: Columbia University Press.

Ghet. 2012. "Z bloka snajper«. Ghetbangarap - Mixtape. Zgoščenka. Velenje: Samozaložba. 1.

Gjurin, Velemir. 1974. »Interesne govorice sleng, žargon, argo«. Slavistična revija 22/1: 65-81.

Izić. 2015. „Brez bontona«. Družinski portret. Zgoščenka. Cerknica: Samozaložba. 9.

Izić. 2015. »Budilka«. Družinski portret. Zgoščenka. Cerknica: Samozaložba. 3. Izić. 2012. »Ljubezenska pesem«. Ulica brestov. Zgoščenka. Cerknica: Samozaložba. 15.

Jesenšek, Marko. 2008, 2009. »Trubarjeva in Küzmičeva različica slovenskega knjižnega jezika«. Slavistična revija 56/4 (2008), 1 (2009): 199-209.

Jizah, Marko Godnjavec. 2009. »Prerez dela artista znanega pod imenom ALI EN«. Radio Študent. Http://old.radiostudent.si/article.php?sid=20676, 24. 10. 2016.

Josipovič, Damir. 2006. Učinki priseljevanja v Slovenijo po drugi svetovni vojni. Ljubljana: Založba ZRC, ZRC SAZU.

Katana, Miss. 2010. »Harem«. Estrogen. Zgoščenka. Ljubljana. 10. 
Klemen Klemen. 2003. „Slovenija«. Hipnoza. Zgoščenka. Ljubljana: Nika Records. 4.

Klemen Klemen. 2000. »Trnow I/The Neralić Story«. Trnow stajl. Zgoščenka. Ljubljana: Nika Records. 5.

Kos, Drago. 2012. "»Avtohtona« evropska džamija?«. V Dve domovini 36. 89-100.

Kusterle, Jernej. 2014. "Zgodovinski in tipološki pregled ulične poezije«. V Jezik in slovstvo LIX/4. 97-110.

Kusterle, Jernej. 2016. Teorija slovenske ulične poezije in družbeni kontekst. Magistrsko delo [študentska Prešernova nagrada Filozofske fakultete Univerze v Ljubljani v letu 2016]. Ljubljana: Filozofska fakulteta Univerze v Ljubljani, Oddelek za slovenistiko.

Leskošek, Vesna. 2005. »Uvod: Med nestrpnostjo in sovraštvom«. V Mi in oni - Nestrpnost na Slovenskem, ur. Vesna Leskošek, 9-19. Ljubljana: Mirovni inštitut.

Mandelker, Steven. 1994. »The Radical Feminist Attack on Reason«. V Reason Papers; A Journal of Interdisciplinary Normative Studies. VB: Patrington Pres. 50-57.

Murat \& Jose feat. Tomi Meglič. 2002. »Od ljudi za ljudi«. V besedi je moč. Zgoščenka. Ljubljana: T3S MUZIK. 8.

Nemir feat. Mulac. 2012. »Ić je zanič«. Boj za obstoj. Zgoščenka. Velenje: Samozaložba. 17.

Rabaka, Reiland. 2012. Hip Hop's Amnesia. UK: Lexington Books.

Radić. 2009. »Zgodba zase«. Zgodba zase. Zgoščenka. Ljubljana: Street13. 2.

Register, Cheri. 1989. »American Feminist Literary Criticism: A Bibliographical Introduction«. V Feminist Literary Criticism; Explorations in Theory (druga izdaja). ZDA: The University Press of Kentucky. 1-28.

Rošker, Jana S. 2010. »Multikulturnost in diktatura strpnosti : primer Kitajske«. V Šolsko polje 21/5-6. 137-149.

Samaluk, Barbara. 2008. Elektronski Disneyland sovražnosti (Učinki in regulacija sovražnega govora na spletu). Magistrsko delo. Ljubljana: Fakulteta za družbene vede Univerze v Ljubljani.

SSP. 200o. »Tretja Mojzesova knjiga (Levitik) [3Mz]«. V Sveto pismo Stare in Nove zaveze. Ljubljana: Svetopisemska družba Slovenije.

Štuhec, Ivan Janez. 2004. »Ali sodobna civilizacija izničuje razliko med spoloma?«. V Bogoslovni vestnik 64/3. 481-497. 
Trkaj feat. Adam Velić. 2013. »Razbijte stereotipe«. Vse je OK. Zgoščenka. Ljubljana: Samozaložba. 9.

TŠ. 2001. »Klemen (ne) gre na Štajersko«. Mladina (portal). Http://www. mladina.si $/ 87778 / \mathrm{m}$ - $\quad \mathrm{klemen} /$ ?utm_source=tednik\%2F200104\%2Fclanek\%2Fm- klemen\%2F\&utm_medium=web\&utm_campaign=oldLink, 24. 10. 2016.

Ustava Republike Slovenije 2013. »14. člen«. Https://zakonodaja.com/ustava/ urs/14-clen-enakost-pred-zakonom, 24. 10. 2016.

Varuh človekovih pravic. 2006. »Definicija sovražnega govora in njegovo omejevanje v ustavi, zakonih in konvencijah". Http://www.varuh-rs.si/medijsko-sredisce/sporocila-za-javnosti/novice/detajl/definicija-sovraznega-govora-in-njegovo-omejevanje-v-ustavi-zakonih-in-konvencijah/?cHash=62215281663460272b7f6a1ca1d2efo4, 18. 10. 2016.

Velikonja, Nataša. 1999. »Narod, nacionalna država in homoseksualnost«. V Časopis za kritiko znanosti 27/195-196. 137-151. 


\section{Recepcija del Draga Jančarja na Češkem}

Iveta Bůžková

Filozofska fakulteta Masarykove univerze v Brnu

Faculty of Arts, Masaryk University in Brno

iveta.buzkova@gmail.com

Prispevek se osredotoča na prevode Draga Jančarja v češčino. V prvem delu so predstavljeni češko-slovenski kulturni in predvsem literarni odnosi in najpomembnejši prevajani avtorji. Drugi del govori o obdobju po letu 1991, ko se ponovno razvija češko-slovensko literarno sodelovanje. Tretji del je namenjen prevodom in recepciji Draga Jančarja na Češkem.

Ključne besede: češko-slovenski literarni odnosi, češko-slovenski prevodi, Drago Jančar

Reception of Drago Jančar in the Czech Republic

The article focuses on a translation of the works of Drago Jančar into Czech. The first part describes Czech-Slovene cultural and literary relations and the most important translated authors. The second part speaks about the period after 1991 when CzechSlovenian relations started to envolve again. The third part is dedicated to the translation and reception of Drago Jančar in the Czech Republic.

Key words: Czech-Slovenian literary relationships, CzechSloveninan translations, Drago Jančar 


\section{Češko-slovensko literarno sodelovanje $\mathrm{e}^{\mathrm{I}}$}

Češko-slovenski kulturni stiki so bili ves čas tesnejši kot na primer češko-srbski ali češko-hrvaški. Slovenci so več let, podobno kot Čehi, pripadali Avstro-Ogrski in imajo del skupne zgodovine. Češka kultura je pomembno vplivala na razvoj slovenske umetnosti in književnosti, predvsem v 19. stoletju. Kot češko-slovensko literarno sodelovanje lahko razumemo poročila o književnem življenju in prevode literarnih del, izdanih knjižno, $\mathrm{v}$ revijah ali v časopisih. Tradicija češko-slovenskega kulturnega in literarnega sodelovanja sega že v 16 . stoletje, do revolucije in pomladi narodov leta 1848 se je začela živahna prevajalska dejavnost. Petr Mainuš je češko-slovenske literarne stike zaradi preglednosti razdelil v šest obdobij: 1. obdobje (1882-1918), 2. obdobje med vojnama (1918-1940), 3. obdobje po drugi svetovni vojni (1946-1948), 4. pasivno obdobje (1949-1956), 5. obdobje popuščanja medsebojnih odnosov (1957-1989) in 6. obdobje od let 1990/1991 dalje (Mainuš 2005).

Intenzivni medsebojni češko-slovenski literarni stiki se začenjajo leta $1832 \mathrm{~s}$ prvim prevodom najbolj znanega slovenskega pesnika Franceta Prešerna, ki ga je prevedel F. L. Čelakovský. Leta 1882 je bil izdan prevod besedila Tugomer Josipa Jurčiča in Vladimirja Levstika, največ pa so prevajali Ivana Cankarja, Zofko Kveder, Frana Govekarja, Frana Erjavca ali Ivana Tavčarja (Mainuš 2005). Kot opozarja Oton Berkopec, je veliko (tudi poznejših) prevodov neberljivih zaradi zastarelosti pa tudi zaradi okornosti, ki je posledica nezadostnega znanja slovenskega jezika. Pogosto so tudi prevajali besedila manj pomembnih avtorjev z nizko umetniško ravnjo, ki pa so imeli osebne stike s prevajalci (Berkopec 1956, 237-238). Na slovenski strani so delovali prevajalci kot Alojzij Benkovič, Fran Gestrin, Leopold Gorenjec, Jože Debevec, Ivan Tomšič ali France Tomšič, na Češkem pa že prevajalci z jezikovno izobrazbo, ki so študirali slavistiko na Dunaju ali v Pragi, na primer knjižničar univerzitetne knjižnice v Pragi Jaromír Borecký, urednik revije Slovanský přehled Adolf Černý, Josef Penížek in mnogi drugi (Mainuš 2005).

Obdobje med vojnama lahko označimo kot zlato obdobje medsebojnih literarnih odnosov, ko je poraslo število prevodov, predvsem na Čehoslovaškem. Prevajana so bila literarna dela Ivana Cankarja, Vladimirja Levstika, Frana Saleškega Finžgarja, Ivana Tavčarja in Ivana Preglja. V slovenščino so prevajali avtorje, kot so bili Marie Majerová, Ivan Olbracht, 
Jiří Wolker ali Karel Čapek. Do konca aktivnega medsebojnega sodelovanja je prišlo z začetkom druge svetovne vojne. Po drugi svetovni vojni se je ponovno povečalo število prevodov v obeh državah. Prevedeno je bilo skupaj šestintrideset jugoslovanskih knjig, od tega trinajst iz slovenščine, na primer Ivan Cankar, Ivan Tavčar, Prežihov Voranc, Tone Seliškar in Vladimir Bartol (Mainuš 2005).

Razcvet sodelovanja je nasilno prekinil razkol med Jugoslavijo in ZSSR. V letih 1949-1953 torej iz političnih razlogov ni izšel noben prevod slovenske (in tudi srbohrvaške) literature. $V$ šestdesetih letih je s praško pomladjo nastopila renesansa medsebojnih literarnih odnosov. Spet se prevajajo klasiki kot Ivan Cankar, pa tudi Srečko Kosovel, France Bevk ali Oton Župančič. V slovenščino so bile prevedene knjige čeških avtorjev, na primer Jaroslava Seiferta, Karla Čapka, Jaroslava Haška ali Josefa Škvoreckega (Šnytová 2014, 457-461).

Po padcu komunizma na Čehoslovaškem leta 1989 in izjavi samostojne Slovenije leta 1991 je prišlo do ponovnega razvoja medsebojnih političnih, kulturnih in literarnih odnosov, ki so se navezali na tradicijo zgodovinskega sodelovanja obeh držav.

\section{Češko-slovenski prevodi po letu 1991}

Kot smo že omenili, se po političnih spremembah na začetku devetdesetih let ponovno razvijajo tudi češko-slovenski literarni odnosi. V zadnjih letih je izšlo pet antologij slovenske poezije, dve antologiji kratke proze (Promlky času, Vně hranic) in antologija slovenske drame. Poleg antologij izhaja veliko prevodov slovenskih del, največje število v letih 2004-2005, ko je bilo izdano deset knjig. Veliko število prevodov iz slovenščine izhaja s pomočjo subvencij slovenskih institucij, na primer Društva slovenskih pisateljev (Trubarjev sklad) ali Centra za slovenščino kot drugi/tuji jezik, ki financira lektorate slovenščine na tujih univerzah. Slovenske knjige na Češkem izdajajo na primer založbe Větrné mlýny, Kniha Zlín, Host, Mladá fronta, Volvox Globator, Dauphin in druge (Kozár 2011, 189-198).

Pomembno vlogo pri izbiri izdanih del igrajo osebni stiki čeških prevajalcev in slovenskih pisateljev. Najbolj prevajani avtor je Drago Jančar; sledijo mu Aleš Debeljak, Žarko Petan, Andrej Skubic, Tomaž Šalamun, Goran Vojnovič in drugi. Za razliko od predhodnih obdobij so zastopani avtorji vseh generacij, torej klasiki slovenske literature (Ivan Cankar, Vladimir Bartol, Edvard Kocbek), starejši avtorji (Žarko Petan), avtorji srednje gener- 
acije (Aleš Debeljak, Alenka Jensterle Doležal) do mlajše generacije (Suzana Tratnik, Goran Vojnovič, Dušan Čater) (Kozár 2011, 189-198).

Od sedemdesetih let 20. stoletja je najplodovitejši prevajalec iz slovenščine literarni kritik František Benhart (1924-2006), ki je izrazito vplival na recepcijo slovenske literature na Češkem. Prevedel je dvainsedemdeset knjig, številne pesmi in drame ter je bil glavni prevajalec Draga Jančarja in Aleša Debeljaka. V devetdesetih letih se uveljavljajo tudi mladi prevajalci - zlasti absolventi slovenistike na Karlovi Univerzi v Pragi (od leta 1993), Masarykovi univerzi v Brnu (od leta 1995) ali Univerzi v Pardubicah (od leta 2007). Med njimi na primer Petr Mainuš, Libor Doležán, Aleš Kozár, Radek Novák, Hana Chmelíková-Mžourková, Alena Šamonilová, Kristina Pellarová, Kamil Valšík, Martina Šaradínvá, Pavel Šaradín in drugi (Przybylski 2011, 229-239). Iz starejše in srednje generacije je treba še omeniti Ivana Dorovskega, Milado Nedvědovo, Alenko Jensterle-Doležal, Jano Špidurovo in Davida Blažeka.

\section{Prevodi Draga Jančarja v češčino}

Drago Jančar sodi med najbolj znane in najbolj prevajane slovenske avtorje. Je pisatelj, avtor krajše proze, esejist, pa tudi dramatik. Njegova dela so bila prevedena $\mathrm{v}$ več kot 20 jezikov, največkrat $\mathrm{v}$ nemščino, češčino in hrvaščino. $V$ češkem prevodu so izšli njegovi štirje romani, dve knjigi kratke proze, drama in veliko esejev. Leta 1990 je bil izdan prevod njegovega romana Galjot (v češčini Galejník), ki ga je prevedel František Benhart. ${ }^{2}$ Galjot žanrsko sodi predvsem na področje zgodovinskega romana, vsebuje tudi nekatere nastavke modernističnega ali postmodernističnega romana, pomembno vlogo ima zlasti metafora. Leta 1999 je izšel avtobiografski roman Posmehljivo poželenje, $\mathrm{v}$ češkem prevodu Františka Benharta pod nazivom Chtíč chtíc nechtíc. O jiném rozumění; kraj dogajanja je v ZDA. ${ }^{3}$ Leta 2003 je bil izdan Jančarjev roman Katarina, pav in jezuit, v češčini Kateřina, páv a jezuita; spet v prevodu Františka Benharta. Gre za zgodovinski roman, ki opisuje ljubezensko razmerje med nekdanjim jezuitom, oskrbnikovo hčer Katarino in stotnikom Windischem (pavom). ${ }^{4}$ Doslej zadnji roman Severni sij je izšel leta 2009 pod nazivom Polární záře v prevodu Libora Doležána. Roman se dogaja v Sloveniji pred drugo svetovno

\footnotetext{
2 Jančar, Drago. 1990. Galejník. Praha: Odeon.

3 Jančar, Drago. 1999. Chtíc chtíč nechtíc. Praha: Volvox Globator.

4 Jančar, Drago. 2002. Kateřina, páv a jezuita. Praha: Paseka.
} 
vojno. Leta 1995 je izšel izbor kratke proze iz Jančarjevih knjig Smrt pri Mariji snežni, Pogled Angela, Augsburg in druge resnične pripovedi, v prevodu Františka Benharta kot Pohled anděla. ${ }^{6}$ Leta 2003 so bile pod nazivom Př́zrak $z$ Rovenské izdane novele iz knjig Pogled Angela in Prikazen iz Rovenske, spet v prevodu Františka Benharta. Benhart je tudi prevedel do sedaj edino v češčino prevedeno Jančarjevo dramo Halštat (2000, z istim naslovom). ${ }^{7}$ Prevedeni so bili tudi nekateri eseji, na primer Př́běh, který můžete zaspat iz knjige Duša Evrope (2007, prevod Petr Mainuš), Brioni: eseje (2005, prevod František Benhart, Hana Chmelíková in David Blažek) ${ }^{8}$ in Přičky z Jákobova žebříku (izbor esejev, prevod Petr Mainuš).

Kakor je bilo že omenjeno, je imel František Benhart izrazit vpliv na recepcijo slovenske literature na Češkem. Bralci na Češkem so se lahko seznanili z Jančarjevimi deli skoraj samo skozi njegove prevode vse do njegove smrti. Ko govorimo o recepciji Draga Jančarja na Češkem, moramo poudariti recenzije čeških literarnih kritikov. Najpogosteje jih pišejo že omenjeni češki slovenisti, na primer Aleš Kozár, Libor Doležán, Hana Chmelíková, Kamil Valšík, Petr Mainuš, ki so hkrati tudi avtorji Jančarjevih prevodov. Na eni strani gre za strokovnjake, ki dobro poznajo slovenščino in kulturni politični kontekst Jančarjevih del, na drugi strani pa ne moremo govoriti o popolnoma objektivnem pogledu.

\section{Seznam prevodov Draga Jančarja v češčino}

\section{ROMANI}

Galejník (1990) - Galjot (1978), prevod František Benhart

Chtíč chtíc nechtíc. O jiném rozumění (1999) - Posmehljivo poželenje (1993), prevod František Benhart

Kateřina, páv a jezuita (2003) - Katarina, pav in jezuit (2000), prevod František Benhart

Polární záře (2009) - Severni sij (2005), prevod Libor Doležán

5 Jančar, Drago. 2009. Polární záře. Praha: H+H, 2009.

6 Jančar, Drago. 1995. Pohled anděla. Praha: Volvox Globator.

7 Jančar, Drago. 2003. Př́zrak z Rovenské. Brno: Host; Jančar, Drago. 200o. Halštat. Praha: Divadelní ústav.

8 Jančar, Drago. 2005. Brioni. Praha: Volvox Globator.

9 Jančar, Drago. 2006. Příčky z Jákobova žebříku. Brno: CDK. 
Dnes v noci jsem ji viděl (2018) - To noč sem jo videl (2010), prevod Kamil Valšík

\section{KRATKA PROZA}

Pohled anděla (1995) - Pogled angela (1992), izbor iz knjig Smrt pri Mariji Snežni, Pogled angela, Augsburg in druge resnične pripovedi, prevod František Benhart

Př́źzak z Rovenské (2003) - Prikazen iz Rovenske (1998), novele iz knjig Pogled angela in Prikazen iz Rovenske, prevod František Benhart

\section{DRAMA}

Halštat (2000) - Halštat (1994), prevod František Benhart

\section{ESEJI}

Příběh, který můžete zaspat (iz knjige Duša Evrope, 2007), prevod Petr Mainuš

Brioni: eseje (2005) - Brioni: eseji in drugi zapisi (2003), prevod František Benhart, Hana Chmelíková, David Blažek

Příčky z Jákobova žebř́íku (2006) - Klini z lestve sv. Jakoba (izbor esejev), prevod Petr Mainuš

\section{REVIJALNE OBJAVE}

Vzpomínky na Jugoslávii (1991) - Spomini na Jugoslavijo. In: Lettre internationale, 1991, č. 28, s. 32-38, prevod František Benhart

Zjevování v prosinci (1991) - Prikazovanje. In: Literární noviny, 1991, roč. 2, č. 50, s. 10, prevod František Benhart

Zpráva z vysněné země - vidina a skutečnost (1992) - Poročilo iz devete dežele - privid ali resničnost. In: Lettre internationale, 1992, č. 7, s. 22-24, prevod František Benhart

Zjevování v prosinci (1992) - Prikazovanje. In: Lettre internationale, 1992, č. 8, s. 4-5, prevod František Benhart

Smrt u Panny Marie Sněžné (1992) - Smrt pri Mariji Snežni. In: Revue otevřené kultury, 1992, roč. 3, č. 6, s. 58-64, prevod František Benhart

Rozbitý džbán (1992) - Razbiti vrč. In: Svět a divadlo, 1992, č. 4, s. 76-80, prevod František Benhart

Špiclování Godota (1992) - Zalezujoč Godota. In: Svět a divadlo, 1992, č. 4, s. 81-107, prevod František Benhart 
Augšpurk (1993/1994) - Augsburg. In: Lettre internationale, 1993/1994, č. 11, s. 1-2, prevod František Benhart

Vztahy, především nebezpečné (1994) - Razmerja, predvsem nevarna. In: Lettre internationale ,1994, č. 12, s. 25-26, prevod František Benhart

Zapomínání znamená nové násilí (1994) - Pozaba pomeni novo nasilje. In: Scriptum, 1994, roč. 4, č. 14, s. 59-62, prevod František Benhart

Ultima creatura (1995) - Ultima creatura (fragment). In: Denní telegraf, 1995, roč. 4, č. 169, př́l. Telegraf na neděli (22. 7. 1995), prevod František Benhart

Egyptské hrnce masa (1995) - Egiptovski lonci mesa. In: Souvislosti, 1995, roč. 6, č. 2, s. 100-118, prevod František Benhart

Konec tisíciletí, účet století (1995) - Konec tisočletja, račun stoletja. In: Tvar, 1995, roč. 6, č. 11, s. 16-17, prevod František Benhart

Křídla nad Panevropou (1995) - Krila nad Panevropo. In: Tvar, 1995, roč. 6, č. 11, s. 17, prevod František Benhart

Volání a kapky (1997) - Klici in kaplje. In: Souvislosti, 1997, roč. 8, č. 1, s. 23 26, prevod František Benhart

Neděle v Oberheimu (1997) - Nedelja v Oberheimu. In: Souvislosti, 1997, roč. 8, č. 1, s. 201-203, prevod František Benhart

Prodloužená minulost (1998), izbor esejev, prevod František Benhart

Poeta a atlet (1998) - Dvanajsto poglavje: Poet in atlet (fragment iz knjige Posmehljivo Poželenje), Proglas, 1998, roč. 9, č. 8, s. 27-29, prevod František Benhart

Brioni (2001) - Brioni. In: Právo, př́l. Salon, 2001, roč. 11, č. 120, s. 4-5, prevod František Benhart

Herodes a pastýř (2002) - Herodež in pastirc. In: Vně hranic. Antologie současné slovinské krátké prózy, prevod Aleš Kozár

Střední Evropa - idea minulosti? (2002) - Srednja Evropa - ideja preteklosti? In: Host, 2002, roč. 18, č. 5, s. 42-43, prevod František Benhart

Joyceův žák (2002) - Joyceov učenec. In: Host, 2002, roč. 18, č. 5, s. 55-58, prevod František Benhart

Vzpoura čtenářů (2002) - Upor bralcev. In: Tvar, 2002, roč. 13, č. 6, s. 6-7, prevod František Benhart

Savana (2003) - Savana. In: Promlky času. Antologie slovinských povídek, 2003, prevod František Benhart

Žert, ironie a hlubší význam (2004) - Šala, ironija in globlji pomen. In: Host, 2004, roč. 20, č. 5, s. 84-90, prevod Hana Chmelíková 
Anděl ho neopustil (2004) - Angel ga ni zapustil. In: Literární noviny, 2004, roč. 15, č. 26, s. 14, prevod František Benhart

Svůdce (2005) - Zapeljivec. In: Host, 2005, roč. 21, č. 9, s. 72-74, prevod František Benhart

Dva snílkové: První stránka (2006) - Dva sanjača. In: Tvar, 2006, roč. 17, č. 4, s. 18-19, prevod František Benhart

Viri

Jančar, Drago. 1990. Galejník. Praha: Odeon.

Jančar, Drago. 1995. Pohled anděla. Praha: Volvox Globator.

Jančar, Drago. 1999. Chtíc chtíč nechtíc. Praha: Volvox Globator.

Jančar, Drago. 200o. Halštat. Praha: Divadelní ústav.

Jančar, Drago. 2002. Kateřina, páv a jezuita. Praha: Paseka.

Jančar, Drago. 2003. Př́izrak z Rovenské. Brno: Host

Jančar, Drago. 2005. Brioni. Praha: Volvox Globator.

Jančar, Drago. 2006. Příčky z Jákobova žebříku. Brno: CDK.

Jančar, Drago. 2009. Polární záře. Praha: H+H, 2009.

Literatura

Berkopec, Oton. 1956. Bilance deseti let. Slovanský přehled 42 (7): 237-238.

Iliteratura.cz. <http://www.iliteratura.cz/Fulltext?Fulltext=jan\%C4\%8Dar $>$. (Dostop 15. 7. 2017.)

Kozár, Aleš. 2011. Překlady ze slovinské literatury posledních dvaceti let $\mathrm{v}$ českém kulturním kontextu. Vzájemným pohledem - V očeh drugega, ur. Alenka Jensterle-Doležal. 189-198. Praha: NK.

Mainuš, Petr. 2005. Bibliografie knižních překladů slovinské literatury do češtiny. Lublaň: Centrum pro slovinskou literaturu.

Przybylski, Michal. 2011. Slovinští autoři v českém prostředí. Překlady ze slovinské literatury po roce 1989: stav, proměna a neuralgické body. Vzájemným pohledem - V očeh drugega, ur. Alenka Jensterle-Doležal, s. 229-239. Praha: NK.

Šnytová, Jana. 2014. Prevodi slovenske književnosti v češčino od leta 1945 do sodobnosti. V Obdobja 33: Recepcija slovenske književnosti, ur. Alenka Žbogar. 457-461. Ljubljana: Filozofska fakulteta.

Vinkler, Jonatan. 2006. Posnemovalci, zavezniki in tekmeci. Češko-slovenski in slovensko-češki kulturni stiki v 19. stoletju. Koper: Annales. 


\section{Nostalgia za komunizmem w polskiej wersji}

Weronika Woźnicka

Instytut Filologii Słowiańskiej, Uniwersytet Śląski w Katowicach

Institute of Slavic Philology, University of Silesia in Katowice

weronikawoznicka@gmail.com

Za komuny było lepiej... To określenie słyszał w Polsce chyba każdy bez względu na wiek. Wśród młodszego pokolenia można zauważyć nostalgię za komunizmem, która przybiera różne formy: restauracje, gadżety (kubki, poduszki itp.), imprezy. Wszystko to w stylu PRL-u. Głównym celem artykułu jest pokazanie, w jaki sposób ludzie młodzi, głównie studenci, którzy nie doświadczyli rzeczywistości komunistycznej Polski, sięgają po symbole okresu PRL-u. Autorka artykułu przeprowadziła również ankietę, której celem było zapytanie osób, które żyły w czasach komuny, co o niej myślą, a także jaki jest według nich powód tego, że młodzi ludzie tak chętnie otaczają się przedmiotami, przypominającymi czasy PRL-u.

Słowa kluczowe: PRL, nostalgia, komunizm, gadżety w stylu PRL-u, ankieta o PRL-u

Nostalgia for Communism - the Polish Version

It was better when there was communism... This sentence has been heard by almost everybody in Poland no matter how old they are. Among the younger generation, it can be seen that nostalgia for communism has different forms: restaurants, gadgets (cups, pillows and others). Everything in PRL style. The main goal of the article is to show how young people, mostly students that 
did not suffer Polish communism, like to use PRL symbols. The author also conducted a survey of which the main goal was to ask the people who lived through the years of communism what they were thinking about communism and what, according to them, was the reason that young people like to surround themselves with objects reminding them of the PRL era.

Key words: PRL, nostalgia, communism, gadgets in PRL style, survey about PRL

Artykuł poświęcony jest nostalgii za komunizmem. Komunizm to pojęcie, o którym każdy słyszał, jednak nie wszyscy wiedzą, czym on jest, jak wygląda/ł, jakie były/są jego wyznaczniki bądź cechy charakterystyczne. Dla lepszego oglądu sytuacji przytoczone zostaną dwie definicje, znajdujące się w internetowym słowniku języka polskiego (www.sjp.pwn.pl). Pierwsza definicja mówi, że komunizm to «ideologia i doktryna społeczna postulująca zbudowanie społeczeństwa bezklasowego, opartego na społecznej własności środków produkcji i równym podziale dóbr». Druga definicja jest bardziej konkretna i wydaje się być bliższa ludziom, szczególnie z krajów, w których komunizm istniał. Brzmi ona następująco: «ustrój totalitarny realizowany w ZSRR, narzucony krajom Europy Środkowej i Wschodniej po II wojnie światowej, oparty na monopolu władzy skupionej w rękach jednej partii». Reasumując, komunizm jest ustrojem, który ma na celu stworzenie społeczeństwa bezklasowego, w którym każdy ma być traktowany tak samo. Wizja nieco utopijna. A jaka była, czy też jest, rzeczywistość? Każdy zna historię na tyle, że jest w stanie odpowiedzieć na to pytanie. Jednak najlepszym źródłem informacji są ludzie, którzy mieli bezpośrednio do czynienia z tym ustrojem, czyli urodzili się, wychowywali i żyli w tym okresie. Takich osób warto zapytać, jak było za komuny. Jednak, jak zawsze bywa w takich sytuacjach, ile osób tyle opinii. Czasami są one sprzeczne, jednak w większości się pokrywają.

Czasy komunizmu w Polsce przypadają na lata 1944-1989. Wydarzeniem, które zapoczątkowało władzę komunistów w Polsce jest utworzenie 21 lipca 1944 Polskiego Komitetu Wyzwolenia Narodowego (PKWN), będącego tymczasowym organem władzy wykonawczej na obszarach wyzwalanych spod okupacji. Wydarzeniem, które doprowadziło do zmian ustrojowych są obrady Okrągłego Stołu, prowadzone od 6 lutego do 5 kwietnia 1989, w wyniku których doszło do pierwszych, częściowo wolnych wyborów w Polsce po II wojnie światowej. 
Okres ponad czterdziestu lat komunizmu w Polsce jest często nazywany mianem „czasy PRL-u”. PRL to skrót od nazwy państwa polskiego, której pełna forma brzmiała Polska Rzeczpospolita Ludowa. Państwo funkcjonowało pod taką nazwą w latach 1952-1989. Określenie „czasy PRL-u” lub po prostu „PRL”, czy ogólnie mówiąc „epoka PRL-u” nawiązuje do czasów komunistycznych, a więc jest przez innych stosowana jako nazwa dla ówczesnego ustroju państwowego. Można ją traktować jako synonim dla hasła „czasy komunistyczne”. Mówiąc prościej, gdy ktoś powie „w PRL-u” oznacza to „za komuny”.

Ponad 25 lat temu Polska pożegnała się z ustrojem komunistycznym. Od tego czasu, a dokładnie od 1989, jest to kraj demokratyczny. Mimo to w ostatnich latach można w Polsce zauważyć swojego rodzaju tęsknotę, czy też nostalgię za dawnymi czasami. Interesujące jest, że tendencja do wspominania komunizmu pojawia się u osób młodych, które nie mają możliwości pamiętać tamtych lat ze względu na to, że po prostu urodziły się albo w latach 8o-tych, kiedy to powoli dochodziło do zmian, albo urodziły się już w wolnej Polsce. Tęsknota ta przejawia się w różnych dziedzinach życia, jak np. w turystyce, kulinariach, rozrywce, i przybiera rozmaite formy.

Spacerując ulicami polskich miast, szczególnie tych większych, np. Warszawy, można napotkać na lokale, przypominające swoim wyglądem te $z$ okresu PRL-u. Do dawnych czasów nawiązują restauracje i, przede wszystkim, bary. Ich wystrój jest wzorowany na wyglądzie miejsc z okresu komunizmu. Na ścianach porozwieszane są plakaty z hasłami typowymi dla tamtych czasów, zdjęcia pochodzące $z$ PRL-u, a także gazety z tamtego okresu, które mają przypominać tapetę. Dla młodych ludzi, a także dla turystów, taki wygląd jest bardzo atrakcyjny. Nie tylko oprawa jest w stylu peerelowskim, także kelnerzy są ubrani odpowiednio do motywu przewodniego. Często również menu nawiązuje do tego z czasów komunistycznych, głównie jednak dotyczy to przekąsek do napojów alkoholowych. Warto dodać, że bary w takim stylu są atrakcyjnie nie tylko ze względu na wygląd, ale także ze względu na cenę, gdyż piwo w takim miejscu kosztuje 4 złote, czyli ok. 1 euro. Nie da się ukryć, że tego typu bary są bardzo oblegane przez młodych ludzi, dlatego jeśli ktoś chciałby spędzić piątkowy wieczór w jednym z takich lokali w Katowicach, to należy się do niego wybrać odpowiednio wcześniej, aby znaleźć wolne miejsce. Ciekawostką jest, że jedną z restauracji w stylu PRL-u odwiedził podczas swojego pobytu w Polsce Bruce Willis. Szczęśliwym lokalem była Oberża pod Czerwonym Wieprzem w Warszawie. 
Dużą popularnością $\mathrm{w}$ ostatnim czasie cieszą się również różnego rodzaju imprezy organizowane w stylu PRL-u. Sylwester, Andrzejki, bal karnawałowy. To tylko trzy $\mathrm{z}$ wielu zabaw, które można urządzić według dawnych standardów. Wystrój sali zawiera motywy z PRL-u (mogą być podobne do tych, jakie znajdują się w restauracjach i barach, o których wspomniano w powyższym akapicie). Przeważnie uczestnicy takich wydarzeń muszą ubrać się odpowiednio do tamtego okresu. Organizatorzy dbają również o oprawę muzyczną. Na większości tego typu imprezach obowiązują piosenki, które były popularne w latach 60., 70. i 80. Jeśli chodzi o jedzenie, to czasami również ono w jakiś sposób odpowiada standardom komunistycznym. Dotyczy to jednak bardziej przekąsek niż dań głównych. Wśród gości imprez w stylu PRL-u częściej są ludzie młodzi, którzy nie żyli lub nie pamiętają tamtych czasów. Pokazuje to, że czasy komunizmu mają w sobie coś, co przyciąga młodych i sprawia, że bardzo chętnie biorą udział w tego typu zabawach.

W sklepach można znaleźć wiele gadżetów, które nawiązują do motywów peerelowskich. Kupić można praktycznie wszystko: kubki, magnesy, poduszki, koszulki i inne. Wszystkie te rzeczy zawierają coś charakterystycznego dla tamtych czasów, np. plakaty, zdjęcia, typowe hasła. Wpisując w wyszukiwarce internetowej hasło: "gadżety z PRL-u” wyskoczą adresy stron sklepów internetowych, które oferują właśnie takie przedmioty. Zaskakująca jest liczba tych sklepów. Okazuje się, że nie jest ich mało, a zakup takich peerelowskich pamiątek reklamują jako dobry prezent na prawie każdą okazję (nawet ślub).

Mówiąc o nostalgii za czasami PRL-u, czy też komunizmu, nie można pominąć instytucji, której zadaniem jest kolekcjonowanie różnego rodzaju zbiorów i udostępnianie ich publiczności. Mowa o muzeum. W Polsce powstają prywatne muzea, o niewielkiej powierzchni, które gromadzą rzeczy z czasów komunistycznych. Jednym z takich miejsc jest „Czar PRL”, muzeum mieszczące się w dawnej fabryce PZO przy ul. Mińskiej 25 w Warszawie. Całość mieści się w starym mieszkaniu, które zostało umeblowane i wyposażone zgodnie z panującą modą minionej epoki. Oprócz zwiedzania lokalu właściciele oferują także zwiedzanie Warszawy, m.in. proponują wycieczkę śladami PRL-u. Jednym z większych muzeów prezentujących historię Polski Ludowej jest Muzeum PRL-u w Rudzie Śląskiej, prowadzone przez Fundację Minionej Epoki. W placówce prezentowane są głównie wnętrza mieszkań oraz przedmioty codziennego użytku, pochodzące z okresu od 1945-1989. W jednym z pomieszczeń zorganizowano 
kino, w którym wyświetlane są kroniki filmowe i peerelowskie Dobranocki. Istnieje również ekspozycja plenerowa, która zawiera zbiory motoryzacyjne tamtego okresu, np. samochód FSO Warszawa, Moskwicz 400 i inne. Warte uwagi jest także Muzeum PRL-u w Krakowie. Instytucja ta jest stosunkowo młoda, gdyż założona została w styczniu 2013 roku. Najciekawsze jest jednak to, że zbiory muzealne można obejrzeć w Internecie. Placówka prowadzi bowiem katalog online, który jest ciągle uzupełniany i ulepszany.

Warto wspomnieć również o ciekawym projekcie naukowo-badawczym. Para dziennikarzy, Izabela Meyza i Witold Szabłowski, zdecydowała na pół roku przenieś się do PRL-u. Na przenosiny wybrali rok 1981, jak tego dokonali? Znaleźli mieszkanie, które zachowało meble i akcesoria z okresu PRL-u. Sami dziennikarze postanowili zrezygnować z komórek, Internetu i innych luksusów, które oferuje XXI wiek. Również poprzez swój wygląd i zachowanie postanowili dopasować się do minionej epoki, tzn. nosili ubrania pamiętające lata 8o., zmienili swój wygląd zewnętrzny, czyli uczesanie, na takie, które było modne w tamtych czasach. Próbowali również stać w długich kolejkach, kupować na kartki, gotować według przepisów polecanych przez „Przyjaciółkę”, a po Warszawie chcieli przemieszczać się legendarnym fiatem 126p. Wszystko to po to, żeby przekonać się na własnej skórze, czym różni się współczesne życie od tego, w którym żyli ich rodzice. Jakie wyciągnęli wnioski i czy wytrwali w swoim eksperymencie, tego można się dowiedzieć czytając ich książkę Nasz mały PRL. Pół roku w M-3 $z$ trwała, wąsami i maluchem.

Jak już wspomniano na początku artykułu, w Polsce coraz popularniejsze staje się wspominanie komunizmu, szczególnie przez osoby młode. Zastanawia fakt, dlaczego to właśnie ludzie młodzi najchętniej kupują gadżety wyglądające jak te $\mathrm{z}$ dawnych czasów. Czy jest to jakiś rodzaj mody, ironii, a może jeszcze coś innego? Autorka niniejszego artykułu postanowiła zapytać osoby, które żyły w czasach komuny, co o niej myślą, a także jaki jest według nich powód tego, że młodzi ludzie tak chętnie otaczają się przedmiotami, przypominającymi czasy PRL-u.

Ankieta, zatytułowana Za komuny było lepiej (?), składała się z 4 pytań i była w pełni anonimowa. Wszystkie pytania $\mathrm{z}$ wyjątkiem pierwszego miały formę otwartą i brzmiały następująco:

1. Czy żył/a Pan/i w czasach PRL (urodzeni do roku 1980)? - odpowiedź tylko „tak” lub „nie”.

2. Czy podziela Pan/i opinię, że „Za komuny było lepiej”? Jeżeli tak, to co według Pana/i było za „komuny” lepsze? - pytanie otwarte. 
3. Jaki jest według Pana/i powód tęsknoty za czasami komunizmu, szczególnie wśród osób, które nie wychowywały się w tym okresie? - pytanie otwarte.

4. Czy chciałby/aby Pan/i, żeby coś z tamtych czasów wróciło? Jeżeli tak, to co? - pytanie otwarte.

Ankieta była dostępna na stronie internetowej: https://docs.google. com/forms/d/1OjWuc2lvS33aLtg 3 GTiKGdfeWP-K6BSjl8CQSxup74k/ viewform?edit_requested=true [data dostępu: 05.11.2016]. W ankiecie wzięło udział 31 osób. Analizując uzyskane odpowiedzi można powiedzieć, że znaczna większość osób, które podzieliły się swoją opinią, to osoby znające czasy PRL-u, a więc takie, które w tym okresie żyły, doświadczyły jego specyfiki. Grupę docelową stanowili ludzie, którzy urodzili się do 1980 roku. O tym, że ankietowani spełnili założone kryteria, świadczą odpowiedzi udzielone na pytanie pierwsze.

Pytanie pierwsze miało, jak już wspomniano, formę zamkniętą. Ankietowani mieli do wyboru tylko dwie odpowiedzi: „tak” lub „nie”. Celem tego pytania było rozeznanie, ile osób urodziło się i wychowywało w czasach komunistycznych. Jednak, o czym pisano na początku artykułu, komunizm w Polsce datuje się na okres od 1944 do 1989, a pytanie ograniczono do roku 1980. Decyzja taka była spowodowana tym, że osoby, które urodziły się $\mathrm{w}$ roku 1980 pamiętają $\mathrm{z}$ pewnością więcej z ostatnich lat PRL-u, gdyż miały wtedy 9 lat, niż osoby, które urodziły się na przykład w roku 1985. Spośród 31 uczestników ankiety tylko 4 osoby, odpowiedziały przecząco na pytanie nr 1, co może oznaczać, że urodziły się w latach 80. albo już po 1989 roku. Jednak, mimo odpowiedzi „nie”, 3 z 4 osób udzieliły odpowiedzi na kolejne pytania. W związku z tym należy powiedzieć, że znaczna większość, 27 z 31 osób, żyła w czasach peerelowskich, a więc stanowiła grupę docelową, która była założeniem autorki artykułu podczas tworzenia formularza.

„Za komuny było lepiej”. Zdanie to brzmi dziwnie, można by nawet powiedzieć, że trochę absurdalnie, a jednak, jak można przeczytać w jednym z esejów polskiego dziennikarza, „Ze świecą szukać Polaka, który jest wolny od mówienia podobnych głupot” (Smoleński 2002). Faktycznie, stwierdzenie, że w czasach komunistycznych było lepiej słyszał prawdopodobnie każdy bez względu na wiek i w różnych sytuacjach życiowych. $Z$ tego powodu drugie pytanie ankiety nawiązywało do opinii, że w czasach komunistycznych było lepiej. Ankietowani mieli odpowiedzieć, czy zgadzają się z 
tym sformułowaniem. Dodatkowo, jeśli potwierdzają, że „Za komuny było lepiej", poproszono ich o napisanie, co według nich było wtedy lepsze.

Znaczna większość osób udzieliła przeczącej odpowiedzi na pytanie numer 2. Wśród 30 osób, które odpowiadały na wszystkie pytania, tylko dwóch ankietowanych zgodziło się z opinią, że w tamtym okresie było lepiej. Według tej dwójki w czasach komunistycznych pozytywnym aspektem było to, że wśród społeczeństwa była większa równość, ludzie bardziej cieszyli się z każdej zdobytej bądź kupionej rzeczy, było więcej możliwości znalezienia pracy, ludzie byli dla siebie milsi, a także lepiej przeżywano święta - dało się odczuć atmosferę świąt, gdyż wtedy były w domu rzeczy niedostępne w ciągu roku (np. pomarańcze). Dwie inne osoby stwierdziły, że zarówno zgadzają się, jak i nie zgadzają z opinią, iż „za komuny było lepiej”. Jako plusy tamtego okresu wymieniają (znowu) większy szacunek do posiadanych rzeczy, lepszą opiekę socjalną, darmową służbę zdrowia, opiekę dentystyczną w szkole i przede wszystkim - lepsze kontakty międzyludzkie, co skutkowało bezinteresowną pomocą. Minusami dla tych osób były, charakterystyczne dla tego okresu, kolejki, problem z dostępnością towarów w sklepie oraz zamknięcie Polski na nowinki z Zachodu. Niektórzy ankietowani nie udzieli odpowiedzi „tak” lub „nie”. Można tylko się domyślać, że raczej nie zgadzają się z opinią, iż w okresie PRL-u żyło się lepiej. Ciekawe jest, że mimo to, iż ludzie nie wspominają tego okresu najlepiej, większość jednak napisała, co było wtedy lepsze. Odpowiedzi były wyrażone w różny sposób, jednak w dużej mierze się pokrywały. $U$ ankietowanych powtarzały się przede wszystkim dwie opinie:

1) W tamtym okresie było mniejsze bezrobocie, ponieważ każdy kto chciał pracować miał zatrudnienie.

2) Relacje międzyludzkie były lepsze niż teraz.

Podsumowując, mimo, że większość osób twierdzi, iż zdanie „za komuny było lepiej” jest nieprawdziwe, to jednak duża liczba ankietowanych napisała, co uznaje za plusy ówczesnego systemu. Oznacza to, że jednak współczesne czasy nie są idealne we wszystkich kwestiach organizacji życia ludzkiego.

Tęsknota (czy też nostalgia) to «uczucie żalu wywołane rozłąką z kimś, brakiem lub utratą kogoś albo czegoś». Jak już wspomniano, w Polsce można znaleźć różne formy tęsknoty za czasami komunizmu. Przedmiotami o tematyce peerelowskiej otaczają się głównie ludzie młodzi, którzy w tamtym okresie nie żyli lub po prostu go nie pamiętają. Dlaczego ludzie w ogó- 
le tęsknią za PRL-em? Uczestnicy ankiety zostali w trzecim pytaniu poproszeni o napisanie powodu, dlaczego osoby nieznające komunizmu przejawiają jakiś rodzaj nostalgii za tamtymi czasami.

Wśród 30 odpowiedzi tylko jedna brzmi „nie ma”. Pozostałe osoby albo nie wiedzą, skąd nagle takie zainteresowanie komunizmem wśród młodych ludzi ( 3 osoby), albo stwierdzają, że ktoś, kto nie żył w tym okresie nie może za nim tęsknić (1 osoba), albo wymieniają powody, które są różne, jednak, tak jak w przypadku pytania drugiego, bardzo dużo $\mathrm{z}$ nich jest sformułowanych w inny sposób, ale przedstawiają ten sam pogląd. Ankietowani udzielali odpowiedzi typu: brak bezrobocia, większa równość społeczeństwa, poczucie większego wsparcia ze strony państwa. Można jednak wyróżnić trzy najczęściej powtarzające się opinie:

1) Młodzi tęsknią, ponieważ słyszą wspomnienia, sentyment rodziców i dziadków.

2) Komunizm znają tylko $\mathrm{z}$ filmów, a konkretnie komedii Stanisława Barei, który w swoich produkcjach przedstawiał absurdy komunizmu i śmiał się z ówczesnego systemu.

3) Ludzie zapominają o dawnych czasach, idealizują przeszłość.

Okazuje się, że można tęsknić nawet za ciężkimi czasami i tą tęsknotą zarażać innych. Podsumowaniem do pytania nr 3 mogą być słowa cytowanego już wcześniej polskiego dziennikarza, który w swoim eseju stwier$\mathrm{dza}, \dot{z} e$ «na tym polega niezależny od ustroju defekt człowieczej pamięci, że to, co było kiedyś, niemal zawsze wydaje się lepsze od tego, co jest dziś» (Smoleński 2002).

Człowiek przeważnie chce, żeby wróciło coś z czasów jego młodości. Mogą to być różnego rodzaju rzeczy, np. ubrania, muzyka, sposób życia i inne. Dlatego też ostatnie, czwarte pytanie ankiety dotyczyło właśnie powrotów. Zapytano, czy jest coś, co ankietowany chciałby, aby powróciło z okresu PRL-u i jeśli jest, to co.

Spośród osób, które udzielały odpowiedzi, tylko 5 zdecydowało, że nie chciałoby, aby coś powróciło z okresu komunistycznego do dzisiejszych czasów. Pozostali ankietowani wymieniali przynajmniej jedną rzecz, a odpowiedzi w większości się nie pokrywały, jednak znaczna większość nawiązywała do odpowiedzi udzielonych na poprzednie pytania. W związku z tym część osób stwierdziła, że powinien dalej istnieć obowiązek pracy bądź dostępność zatrudnienia dla wszystkich, którzy chcą pracować, a także ludzie powinni okazywać większy szacunek rodzicom, nauczycie- 
lom oraz bardziej doceniać to, co posiadają. Wymieniano również opiekę socjalną, powszechną opiekę medyczną, zakłady przemysłowe, żłobki i przedszkola dostępne dla wszystkich, darmowe mieszkania zakładowe i inne. Spora część osób odpowiadała jednak, że najbardziej by chciała, aby powróciła bliskość i życzliwość ludzi, poczucie wspólnoty, więcej czasu na życie rodzinne, co można połączyć w jedno i nazwać lepszymi kontaktami międzyludzkimi.

W dobie komputerów, telefonów, różnego rodzaju komunikatorów, a więc w okresie, kiedy teoretycznie kontakt $\mathrm{z}$ drugą osobą jest ułatwiony, ludzie chcą, aby powróciły te relacje międzyludzkie z okresu PRL-u. Komunistyczne, to znaczy jakie? To znaczy, że ludzie byli sobie bliżsi, nie traktowali innych $\mathrm{z}$ góry, ponieważ istniała większa równość w społeczeństwie. Pomagali sobie bezinteresownie i nie potrzebowali specjalnych urządzeń elektronicznych ani aplikacji internetowych, aby umówić się z kimś na spotkanie lub kogoś odwiedzić. Można powiedzieć, że współczesność odebrała większości osobom zdolność nawiązywania kontaktów, utrzymywania bliskich relacji. Duża liczba ludzi nie potrafi w dzisiejszych czasach przyjść do kogoś bez uprzedniego powiadomienia. Kontakty międzyludzkie straciły charakter spontaniczny, teraz muszą być uporządkowane i zgodne z jakimś założonym planem.

Analizując wyniki ankiety można powiedzieć, że to właśnie lepsze stosunki międzyludzkie są powodem nostalgii za czasami socjalistycznymi. Młodzi ludzie mogli zasłyszeć sentyment od rodziców lub dziadków, jak to wyglądało dawniej. Również para dziennikarzy, o których wspominano wcześniej, wyciągnęła następujące wnioski ze swojego eksperymentu: «Lata osiemdziesiąte, z całą swą topornością, to czas solidarności, czas wspaniałej, międzyludzkiej chemii, czas, gdy jedni drugich ciężary nosiliśmy» (Meyza i Szabłowski 2012). Nie można jednak wykluczyć tego, że Polskę ogarnęła po prostu zwyczajna moda na peerelowskie gadżety i lokale, a jak to $\mathrm{z}$ modą bywa, młodzi ludzie chcą być na czasie i żyć zgodnie z panującymi trendami. Wydaje się, że można jednak połączyć tęsknotę za komunizmem i nowe kierunki w modzie, o czym wspomina doktor Włodzimierz Pessel: «Wraz z tęsknotą za komuną pojawiły się w Polsce grupy młodych ludzi, którzy właśnie takich przedmiotów szukają. Interesują ich meble vintage, stare książki, płyty winylowe. Niektórzy z nich urządzają mieszkania sprzętami znalezionymi na śmietnikach» (Meyza i Szabłowski 2012).

Należałoby chyba jednak połączyć tęsknotę i modę, gdyż moda vintage w jakiś sposób nawiązuje do nostalgii za starym. Nie zmienia to jed- 
nak faktu, że te lepsze kontakty międzyludzkie są głównym powodem tej tęsknoty, co można wywnioskować z odpowiedzi ankietowanych, a o czym wspominają także autorzy książki Nasz mały PRL. Pół roku w M-3 z trwała, wąsami $i$ maluchem. W dzisiejszych czasach ludzie zatracili zdolność bezinteresownych kontaktów. Oczywiście nie dotyczy to wszystkich. Nie można wsadzać wszystkich ludzi do „jednego worka”, jednak zauważalne są zmiany we wzajemnych stosunkach międzyludzkich. W miejscach przypominających wyglądem lokale peerelowskie można poczuć atmosferę z tamtego okresu. W takich barach, restauracjach wszyscy są sobie bliscy bez względu na wiek, pozycję, zatrudnienie itd. Przejaw nostalgii za peerelem można by określić jako pewien sposób sprzeciwu wobec współczesnemu ciągłemu byciu w biegu, braku czasu dla innych i co najważniejsze braku czasu dla zacieśniania relacji, a jak wiadomo każdy człowiek potrzebuje mieć kogoś bliskiego, a jeśli ciągle skupia się na karierze, to trudno mu potem znaleźć taką osobę, która go w krytycznych momentach wysłucha i wesprze. Może dlatego też powstaje coraz więcej takich miejsc. Pociąg do czasów peerelowskich związany jest także z poszukiwaniem produktów, usług (np. gadżety, wycieczki), które odbiegają nieco od standardowych ofert dostępnych na rynku. Tego wzrostu zainteresowania dawnymi czasami i boomu na pamiątki i lokale z okresu PRL-u najlepiej zaznać będąc w Polsce i udając się do takiego baru. Człowiek na własnej skórze poczuje atmosferę miejsca i bliskość ludzi. Jednym słowem, doświadczy nostalgii za czasami komunizmu.

\section{Literatura}

Meyza, Izabela i Witold Szabłowski. 2012. Nasz mały PRL. Pół roku w M-3 z trwałą, wąsami i maluchem. Kraków: Wydawnictwo Znak.

Smoleński, Paweł. 2002. "Za komuny było lepiej, czyli o kłopotach wspólnej podróży nad morze«. W NOSTALGIA. Eseje o tęsknocie za komunizmem, red. Filip Modrzejewski i Monika Sznajderman, 114-129. Wołowiec: Wydawnictwo Czarne.

\section{Źródła internetowe}

Adventure Warsaw. »Muzeum PRL/Adventure Warsaw«. 2016. Adventure Warsaw. <http://adventurewarsaw.pl/muzeum-prl/>. (Data dostępu: 05.11.2016.) 
Fundacja Minionej Epoki. »Fundacja Minionej Epoki, Muzeum PRL-u«. 2016. Fundacja Minionej Epoki. <http://www.muzeumprl-u.pl/>. (Data dostępu: 05.11.2016.)

Muzeum PRL-u. »Muzeum PRL-u«. 2016. Muzeum PRL-u. <http://www.mprl. $\mathrm{pl} />$. (Data dostępu: 05.11.2016.)

Wydawnictwo Naukowe PWN. »Słownik języka polskiego PWN«. 2016. Wydawnictwo Naukowe PWN. <http://sjp.pwn.pl/>. (Data dostępu: 05.11.2016.) 



\section{Ukrajinske družbene spremembe v romanu Dvanajst krogov Jurija Andruhoviča}

Janja Vollmaier Lubej

Institut für Slawistik, Philologisch-Kulturwissenschaftliche Fakultät, Universität Wien janja.v@windowslive.com

Prispevek predstavi družbene spremembe v Ukrajini po njeni odcepitvi od Sovjetske zveze in v času nove, kapitalistične dobe, kot so predstavljene v romanu Dvanajst krogov ukrajinskega pisatelja Jurija Andruhoviča. Prispevek se ukvarja z ekonomsko podobo postsovjetske Ukrajine in predstavi nekaj ključnih posledic, ki jih lahko opazimo v omenjenem romanu. To so delavske migracije, zapuščeni otroci, prostitucija, odvisnost od alkohola.

Ključne besede: Dvanajst krogov, delavske migracije, zapuščeni otroci, prostitucija, odvisnost od alkohola, kapitalizem

Social Changes in Ukraine in Yuri Andrukhovych's Novel Twelve Rings

The article presents social changes in Ukraine after its secession from the Soviet Union and also in a new, capitalist, era as they are presented in a novel by the Ukrainian writer Yuri Andrukhovych, Twelve Rings. The present contribution examines the economic aspect of post-Soviet Ukraine and presents some of main conesquences they had and which are described in the aforementioned novel. They are economic migration, abandoned children, prostitution, alcoholism.

Key words: Twelve Rings, economic migration, children left behind, prostitution, alcoholic dependence, capitalism 


\section{Postsovjetska Ukrajina}

Ko je leta 1991 razpadla Sovjetska zveza in si je Ukrajina kot njena nekdanja sovjetska socialistična republika namesto totalitaristične stalinistične-leninistične ideologije izbrala pot $\mathrm{v}$ demokratično državo, je bila deležna številnih političnih, gospodarskih, kulturnih in družbenih sprememb. Vzpostavitev oziroma gradnja nove družbene skupnosti je bila zapleten proces. Razpad Sovjetske zveze je potekal po mirni poti, a oblikovanje nove, samostojne države še zdaleč ni bil enostaven. Ob osamosvojitvi Ukrajine so se ustvarila velika pričakovanja za prihodnost v neodvisni državi, ki naj bi postala bogata demokracija s prostim trgom ter polnopravna članica evropske in evroatlantske skupnosti, a se ta pričakovanja (še) niso izpolnila (Sutela 2012). Najsodobnejša Ukrajina beleži približevanja Evropski uniji in tudi njena oddaljevanja (Janukovičeva zavrnitev podpisa pridružitvenega sporazuma med Evropsko unijo in Ukrajino, kar je povzročilo evromajdan) in še danes, sedemindvajset let po osamosvojitvi, ne moremo pisati o konkretnih pomikih.

Ukrajina se je po letu 1991 soočala $\mathrm{z}$ veliko gospodarsko in ekonomsko krizo, ki je bila tudi posledica industrializacije, nekonkurenčnosti (Sutela 2012), država, ki je bila nekdaj vodilna v kmetijski panogi, se srečuje z neizkoriščenimi kmetijskimi površinami, premogovniki, ki so nekoč ustvarjali dobiček, so v novi dobi prinašali izgubo. Mnogi vzroke za slabo finančno stanje države po osamosvojitvi vidijo tudi v prerivanju politikov za oblast oziroma v zamenjavi elit (Kutsyuruba 2011, Sutela 2012, Rjabčuk 2014, Die Ukraine - Land mit zwei Gesichtern 2014). Hkrati se je v državi pojavilo in obdržalo veliko oligarhov, ki so izkoristili čas privatizacije, zaradi sumljivega bogastva pa nadzorujejo gospodarstvo in imajo izstopajočo vlogo tudi v politiki (Unabhängige Ukraine 2015). Rezultat tega je viden še danes, ko lahko opazujemo ogromen prepad med revnimi in bogatimi, vsedovoljenost in kršenje zakona na eni ter kratenje svobode na drugi strani. Zaradi politične nestabilnosti $\mathrm{v}$ nanovo ustanovljeni državi ni bilo mogoče vzpostaviti funkcionalnih administrativnih institucij (Sutela 2012) in s tem, ko je vsakršno spoštovanje zakona izpuhtelo, ukrajinsko gospodarsko okolje ni bilo spodbudno za tekmovanje, vlaganje, razvoj (prav tam). Prav tako se je država soočala $\mathrm{z}$ velikim koruptivnim tveganjem in sivo ekonomijo, ki sta še danes eni večjih ukrajinskih težav. Glede na različne vire siva ekonomija danes v Ukrajini dosega od 20 do 50 \% (Bochi, Povoroznyk 2014, 1). Glede na ocene številnih mednarodnih strokovnjakov odtok denarja kot posledica korupcije presega 10 bilijonov dolarjev letno (Bochi, Povoroznyk 
2014, 2). Denar se izgublja tudi zaradi izplačevanja plač v kuvertah, pri čemer naj bi vrednost takega plačila letno zavzemala 200 bilijonov UAH (prav tam). Dalje, indeks ekonomije svobode ocenjuje, da ima Ukrajina ene slabših pogojev za ekonomski razvoj med državami Evropske unije in nekdanjimi državami Sovjetske zveze (Bochi, Povoroznyk 2014, 4). Glede na indeks zaznave korupcije pa se je država v letu 2013 znašla na 144. mestu od 177. držav (prav tam). Nekateri avtorji korupcijo opisujejo tudi kot endemično (Düvell, Lapšina 2015, Sutela 2012).

Hkrati je bila Ukrajina neuspešna v izvozu in vodenju domačega gospodarstva (Sutela 2012). Nekateri proces ukrajinskega gospodarstva vidijo kot "pošasten divjezahodni kapitalizem, ki je peščici omogočil nenormalno bogatenje, večino pa je pahnil v še globljo revščino" (Die Ukraine - Land mit zwei Gesichtern 2014). Ukrajina je po osamosvojitvi postala svetovna periferija, $v$ kateri so razlike med bogatimi in revnimi še večje in globlje. $\mathrm{V}$ nemški reviji Der Spiegel iz leta 1994 lahko beremo, da je "preteklemu sovjetskemu modelu gospodarstva [...] sledil še absurdnejši, ki nima niti načrta niti trga, temveč mu vlada zakon džungle« (Die Ukraine - Land mit zwei Gesichtern 2014).

Čeprav je Ukrajina prvih sedem let novega tisočletja doživljala gospodarsko rast, se je ta zaradi globalne gospodarske krize leto kasneje ustavila (Unabhängige Ukraine 2015). Pretresljivo je, da je Ukrajina danes druga najbolj revna evropska država, sploh upoštevaje, da je bila sosednja Poljska, ki je danes gospodarsko uspešna, leta 1990 na primerljivem ekonomskem izhodišču: po uradnih podatkih naj bi BDP prve znašal 1.569 USD na prebivalca, druge 1.693 USD, leta 2012 pa je ukrajinski BDP 3.866, medtem ko je poljski 12.707 USD (Fisher 2014).

Hkrati se je postsovjetski posameznik v novi družbi težko znašel. Na nek način je hotel zabrisati vsakršne sovjetske sledi preteklosti in kolektivnega spomina, po drugi strani pa novih oblik pri vzpostavljanju samostojne države ni mogel ali hotel zlahka sprejeti. Vesna V. Godina v svoji monografiji Zablode postsocializma (2014) na podlagi ugotovitev antropologov sklene, da posamezniki v novih družbah ohranjajo delovanja, standarde oz. tisto, kar izvira iz preteklosti, s tem pa novim postsocialističnim institucijam onemogočajo delovanje. Prav tako pogosto ovirajo in onemogočajo postsocialistične spremembe $(2014,111)$. V postsocialističnih družbah nove institucije in prakse niso zaživele in $\mathrm{v}$ družbah obstajajo kot tujek (Hann 2007, 277-278, povz. po Godina 2014, 111). Večina učiteljev iz mesta Černivci je leta 2005 odgovorila, da so spremembe v socialni sferi slabše, 
ljudje pa so se bili zaradi izgube nekdanjega načina življenja prisiljeni prilagoditi novim resničnostim. Precej učiteljev je potrdilo, da so v novi državi medčloveški odnosi postali bolj brezčutni in hladni (Kutsyuruba 2011).

Ukrajina pa se, kakor vse ostale vzhodne države, ni izognila uveljavitvi kapitalizma. Po mnenju antropologov (npr. Hann, Kideckel, gl. Godina $2014,127)$ je $\mathrm{v}$ postsocialističnih družbah šlo za nov tip kapitalizma, imenovanega neokapitalizem, za katerega je značilna "predelava temeljnih kapitalističnih principov na nove, še bolj neegalitarne načine kot zahodni model« (Kiedeckel 2007, 115-116, povz. po Godina 2014, 127). Vzpostavile so se svetovne periferije, ki so rezultat odvisnosti Vzhodne Evrope od svetovnega kapitala, pri čemer je nepravično bogatenje na eni in vse večja revščina na drugi neizpodbitno dejstvo in velik vsesplošen globalizacijski problem, ki se mu tudi Ukrajina ni izognila.

\section{Posledice novih družbeno-ekonomskih resničnosti}

Posledice izpostavljenih težav, s katerimi se srečuje postsovjetska Ukrajina, so delavske in ekonomske migracije ter upad ukrajinskega prebivalstva, zapuščeni otroci, porast alkoholizma in feminizacija revščine, ki se kaže v prostituciji.

Ukrajina se sooča $\mathrm{z}$ upadom pričakovane življenjske dobe, eden od pomembnih vzrokov za to pa je tudi alkohol. Uradni podatki sicer kažejo, da je poraba alkohola na prebivalca $v$ litrih čistega alkohola malo nad evropskim povprečjem in da upada (14,3 za obdobje 2003-2005, 13,9 za obdobje 2008-2010, medtem ko je evropsko povprečje 11,9 oziroma 10,9) (WHO 2014), a poudariti je treba, da podatki niso realni. Strokovnjaki namreč opozarjajo na zavajajoče podatke in da stopnja odvisnih od alkohola pravzaprav narašča (Samokhvalov et al. 2009).

Ukrajina se od osamosvojitve sooča $\mathrm{z}$ množičnim izseljevanjem in je država $z$ eno največjih diaspor na svetu, ki predstavlja 5-6 milijonov ljudi. Ukrajinsko prebivalstvo se je v obdobju 1991-2015 zmanjšalo za devet milijonov (iz 52 na 42,9 milijonov) (Düvell, Lapšina 2015). Sodobna Ukrajina se sooča s številnimi delavskimi migracijami, opazen je porast migracij na Poljsko, zlasti zaradi jezikovnih in kulturnih podobnosti pa tudi zaradi preprostih, brezplačnih birokratskih postopkov (Jaroszewicz 2015, 5). Veliko Ukrajincev dela tudi v drugih evropskih državah, npr. na Češkem, v Italiji, Španiji, na Nizozemskem idr., v glavnem so to slabo plačana dela v neurejenih pogojih. Po podatkih iz leta 2012 je 3,4 \% ukrajinske populacije delavskih migrantov, $25 \%$ pa jih v tujini dela ilegalno (Malinkovska 2006). 
Posledice delavskih migracij so zapuščeni otroci, ki so jih primorani vzgajati stari starši oz. drugi sorodniki ali prijatelji. Jasno je, da odsotnost enega ali obeh staršev povzroča velike travme (Janovič 2015) in hude življenjske preizkušnje. V Ukrajini prva ločitev otroka in starša traja od dveh do petih let. Žalostno je še, da delavske migracije postajajo vse bolj trajne in takšna je tudi vez med vse bolj dejansko in simbolno oddaljenimi otroki ter njihovimi starši (Malinovska 2006).

Nekatere države nekdanje Sovjetske zveze, med njimi je tudi Ukrajina, so postale osrednje države glede prostitucije (Hughes 2003). V seksualni industriji so najbolj popularne ženske iz Ukrajine in Rusije. Med letoma 1991 in 1998 se je v prostitucijo na zahod podalo 500.ooo Ukrajink (Hughes 2003, 11). Leta 1998 je kriminalistična preiskava v Nemčiji ugotovila, da je $87,5 \%$ prostitutk v Nemčiji iz Vzhodne Evrope, od tega 14 \% iz Ukrajine (Hughes 2003, 10). Poleg osnovnih vzrokov (brezposelnost, nizke plače) so vzroki za porast prostitucije tudi $\mathrm{v}$ njeni toleranci $\mathrm{v}$ ukrajinski resničnosti, $\mathrm{v}$ feminizaciji revščine in normalizaciji te problematike. Danes individualna prostitucija v Ukrajini ni kaznivo dejanje. Tragično je, da so žrtve nedelujoče države in njenega sistema tudi otroci, ki so kot ženske prisiljeni v trgovino $\mathrm{z}$ belim blagom.

\section{Odslikava ukrajinske postsovjetske resničnosti v literarnih delih Jurija Andruhoviča}

Jurij Andruhovič (1960) je vidnejši ukrajinski postmodernistični pisatelj, pesnik in esejist, ki je za svoje literarno delo prejel več uglednih domačih in tujih nagrad. V svojih romanih, ki so prevedeni $v$ številne jezike in s katerimi je bil deležen največ kritiške naklonjenosti, piše o posttotalitarni, postsovjetski Ukrajini in položaju posameznika in/ali skupnosti v njej. Andruhovičeva velika ustvarjalna tema je "vprašanje posameznikove in/ali kolektivne identitete $\mathrm{v}$ tranzicijskem in postsovjetskem obdobju « (Vollmaier Lubej 2016, 212) in v svojih romanih želi preseči imperialistično preteklost (prav tam). Njegove literarne osebe določa travmatizirana preteklost, ki ji v sedanjosti niso zmožne ubežati. Andruhovič v svojih romanih, Rekreacije (1992), Moskoviada (1993), Perverzija (1996) in Dvanajst krogov (2003), tematizira imperialistično preteklost, življenje v imperiju in posledice za posameznika in skupnost. Avtor predstavlja usodo posameznika, ki je v poosamosvojitvenem času še vedno ukleščen $\mathrm{v}$ ostaline totalitarnosti in zato ni zmožen nanovo zaživeti. Njegove pripovedi se torej naslanjajo na travmo, na brezizhodnost tako posameznika kot skupnosti. 
V svojem literarnem delu Jurij Andruhovič posebno mesto namenja (Ne) Evropi in položaju Ukrajine $\mathrm{v}$ njej in poudarja zapostavljenost Ukrajine $\mathrm{v}$ Evropi. Avtorjev zadnji roman Dvanajst krogov (2003) se tem vprašanjem, tj. podobi Ukrajine v Evropi, ostalinam totalitarne preteklosti, približa preko tujca, Avstrijca Josepha Zumbrunnena, ki je v svojih opažanjih in pisanjih karseda objektiven, prav tako pa roman tematizira življenje v dobi kapitalizma in potrošništva ter upošteva njene posledice.

\section{Roman Dvanajst krogov}

Ko je leta 2003 izšel roman Dvanajst krogov, ki ga je mogoče brati kot kritiko ukrajinske družbe, so nekateri zaradi slednjega pisatelju očitali zaničevalno upodabljanje Ukrajine in celo trdili, da je plačanec Zahoda. Toda Andruhovič je pisatelj, ki je v svojih literarnih besedilih kritičen do ukrajinske situacije in ji nastavlja objektivno ogledalo, problematike pa niti v esejih niti v romanih ne podaja enostransko, temveč jo osvetljuje s širšekulturnega, širšedružbenega vidika.

$\mathrm{V}$ romanu večperspektivno predstavlja ukrajinsko resničnost ter $\mathrm{z}$ zlom napolnjen pretekli in sodobni čas. Roman Dvanajst krogov je nastal $\mathrm{v}$ času, ko se je Ukrajina navidezno že oddaljila od sovjetske podrejenosti in se začela politično ter kulturno približevati evropski skupnosti oz. njeni ideji. Toda še vedno je zaznati ostaline vseprisotne totalitarnosti ter njenega prepleta $\mathrm{z}$ novo dobo kapitalizma in potrošništva. Videti je, da se krogotok zgodovine zla nadaljuje tudi v novi, neodvisni ukrajinski stvarnosti. Roman predstavlja posameznika in skupnost $\mathrm{v}$ tem modificiranem času in prostoru ter prikazuje posledice, ki smo jim priča danes. To je družba brez vrednot, skupnost, ki se množično izseljuje v sosednje države zaradi boljšega življenja, družba, ki ne spoštuje Romov, družba, ki ji ni mar za umetnost. Namesto naštetega se vzpostavljajo plehkost, hitro, nepošteno bogatenje, izigravanje sistema, laganje idr. Jurij Andruhovič je postmodernistični ukrajinski pisatelj, ki je v literarni prostor vstopil kot pesnik. V romanu Dvanajst krogov se pojavljajo tri osrednje osebe: ukrajinski pisatelj-pijanec Artur Pepa, njegova žena, prevajalka, germanistka Roma Voronič kot usodna ženska in odgovorna mati ter avstrijski fotograf Karl Joseph Zumbrunnen, ki ukrajinščine ne zna, svojo jezikovno pomanjkljivost pa nadomešča s fotografiranjem in s kritičnim očesom dobesedno in simbolno slika ukrajinsko trpko resničnost počasnih vlakov, vizumskih dovoljenj, carinikov, izklopljene elektrike in zlasti žalostno usodo države, ki je sicer imela potencial, a ga ni znala ali zmogla izkoristiti. Med Arturjem, 
Romo in Karlom Josephom je vzpostavljen nevaren ljubezenski trikotnik, ki je za slednjega usoden. Vsi trije se skupaj z ostalimi gosti pripeljejo v Karpate v Krčmo na Mesecu, da bi tam obeležili spomin na pozabljenega ukrajinskega pesnika iz tridesetih let prejšnjega stoletja Bogdana Igorja Antoniča, ki mu pisatelj v šestem poglavju nameni literarizirano fiktivno biografijo, v kateri se poleg njegovih pesmi pojavijo pričevanja, spomini, polresnice, zavajanja, zlasti pa odnos tedanje družbene elite do pesnikovega dela in življenja. Poleg središčnih oseb so v romanu prisotni še Romina hči Kolomeja, profesor, poznavalec Antoničeve poezije, koketnici in glavni junakinji reklamnega videa za alkoholni zvarek Lilija in Marlena, režiser Volšebnik ter tajkun in oligarh Varcabič. V pripovedi ni veliko dogajanja, to pa za Andruhovičev romaneskni opus ni nobena novost. Žanrsko je roman družbenokritični, ljubezenski, kriminalni in detektivski. Jurij Andruhovič $\mathrm{v}$ svojih romanih ustvarja mračno, brezizhodno, groteskno vzdušje, ki se v zgodovinskem času in prostoru nevarno ponavlja v modificiranih oblikah. Tak je tudi roman Dvanajst krogov, ki že v naslovu namiguje na simboliko kroga kot večno ponavljanje in vračanje na začetek.

\section{Analiza}

Analiza zajema predpostavko, da roman Dvanajst krogov večperspektivno odslikava ukrajinske družbene spremembe, ki se kažejo v posttotalitarni in postsovjetski resničnosti. Analiza ob tem želi predstaviti tudi podobo kapitalistične in potrošniške ukrajinske resničnosti, kot je podana v izbranem romanu.

\section{Družbene spremembe v Dvanajstih krogih}

Roman je postavljen $\mathrm{v}$ devetdeseta leta prejšnjega stoletja, $\mathrm{v}$ čas, ko Ukrajina postane neodvisna in samostojna država. Ekonomski strokovnjaki z zahoda so tedaj ocenjevali, da se lahko razvije v stabilno državo s konkurenčnim gospodarstvom. Poleg tega je ukrajinsko gospodarstvo med nekdanjimi državami Sovjetske zveze predstavljalo izjemen gospodarski in industrijski potencial. Po osamosvojitvi se pospešuje propad industrije in kmetijstva, sesuje se bančni sistem, kar vodi v izgube delovnih mest in posledično ekonomske migracije.

Delavski migrantki v romanu sta Lilija in Marlena, ki predstavljata še eno ukrajinsko stvarnost, tj. popredmetenje žensk: Liliji so na Češkem obljubili delovno mesto plesalke, Marlena občasno na Poljskem pleše v 
baru, medtem ko njuna sosošolka Leska $\mathrm{v}$ Benetkah sedi v plačljivem stranišču in čaka na prostovoljne prispevke ljudi. Tako se skozi koketnici in neumni ženski kaže feminizacija revščine in na prvi pogled morda svobodna izbira prostitucije. V romanu snemata reklamo za Varcabičev balzam s pomanjkljivo obleko in sta predstavljeni kot poželjiva objekta. Njun preprost pogovor priča o tem, da ne govorita o svojih čustvih, doživljanjih, preteklih spominih, temveč govorita o tem, kje lahko kaj zaslužita. Podani sta kot sodobni potrošnici, ki morata skrbeti za svoje telo, da bi ugajali in se karseda približali lepotnemu idealu. Lilija in Marlena se razlikujeta samo po svoji zunanjosti in sta tisti sodobnici, ki so ju ustvarili televizija, revije in sovjetski način življenja. Sta punci, ki o ničemer ne razmišljata, premišljujeta, skozi dialoškost pa normalizirata prostitucijo in popredmetenje žensk v sodobni dobi. Njun zaslužek je nizek in jima ne omogoča dostojnega življenja, sta žrtvi sodobnega seksualnega suženjstva. Roman tako prikazuje tudi spremenjen odnos do telesa, telesnosti, poudareni sta detabuizacija spolnosti in svobodno odločanje pri izbiri spolnega življenja. Roma prevara svojega moža Arturja, s čimer krši t. i. tradicionalne vrednote in rahlja t. i. tradicionalni zakon. Pri Romi, Marleni in Liliji se kaže tudi vpliv globalnega trga na dojemanje lepote, sledenje trendom in sprejemanje lastnega telesa kot predmet poželjivosti in komercializacije.

Percepcija delavskih migracij kot narobe razumljeno upanje na boljši jutri je $\mathrm{v}$ romanu podana skozi oči tujca, ki tudi sicer $\mathrm{z}$ največjo ostrino popisuje ukrajinsko resničnost $\mathrm{v}$ svojih pismih avstrijskim prijateljem. Avstrijec Karl Joseph Zumbrunnen, ki ima razmerje z Romo, slednjo prepričuje, naj zapusti domovino in se z njim odpravi kamor koli drugam, s takšnimi prošnjami in obljubami pa je podan kot zahodni bogat sebičnež, ki je na neki točki pozabil, da ima Roma hčer. Zgodi se preobrat, saj ga ljubimka ravno zaradi tega dejstva zavrne. Noče postati transnacionalna mati, ki bi na daljavo skrbela za svojega otroka, se mu oddaljila in ga dala v oskrbo drugim ljudem.

Da se samostojna Ukrajina še ni povsem oddaljila od nekdanjega režima, pričajo Zumbrunnenova pisma, $v$ katerih piše o nepojasnjenih nesrečah, samomorih, izginotjih politikov, novinarjev ipd. Vzpostavlja se nova represija in totalitarnost, nesvoboda izražanja, vse to pa opazi tujec in ne domačini sami. Karl Joseph Zumbrunnen se v Ukrajino vrača večkrat, prvič je tja prišel na začetku devetdesetih, ko je bila povsem nova, samostojna državna tvorba. Svoja opažanja monološko in deskriptivno opisuje v 
pismih avstrijskim prijateljem. O tem, da je samostojna država zapravila svojo priložnost, piše leta 1994:

Ta dežela je imela čudovito priložnost za spremembno, iz stanja trajne popačenosti in oligofreničnega brezupa skoraj bliskovito poskočiti vsaj do stanja normalnosti. Toda izkazalo se je, da število tistih, ki znotraj nje same tega ne želijo in nasploh ne želijo njenega obstoja kot takšnega, bistveno presega vse dopustne meje. (Anduhovič 2006, 11-12)

Videti je, da izmed vseh literarnih oseb le Zumbrunnen kot tujec zmore resneje in bolj poglobljeno analizirati ter pisati o ukrajinski stvarnosti. Preko njegovih pisem izvemo, da Ukrajino pestijo številne težave pri vzpostavitvi nove države, ki se sooča z ostalinami preteklosti. Tako na enem mestu poudari, da je življenje $\mathrm{v}$ nanovo ustanovljeni državi za nekatere nevarno, izpostavi prisluškovanja, nepojasnjene umore, porast kriminala, zlasti pa zlate čase za črni trg s strelnim orožjem. Sedanji totalitarizem ironično imenuje plazeči se, pojavlja se torej še naprej v neodvisni državi, le v drugačni, modificirani obliki. Opaža, da je ljudi strah živeti v takšni državi, neodzivnost organov pregona pa zapiše $\mathrm{z}$ aforizmom: »Policijska država je tam, kjer je policija $v$ enaki meri vsemogočna do poštenih državljanov in nemočna pred zločinci« (Andruhovič 2016, 20).

Dvanajst krogov predstavlja tudi spremenjeno vlogo umetnosti/umetnika v družbi ter spremenjene odnose med posamezniki, pri čemer obe iztočnici stremita $\mathrm{k}$ hitremu in nerazumevajočemu izpraznjevanju bistva. $\mathrm{V}$ romanu je tako prisotna spremenjena podoba umetnosti v sodobni, postmoderni družbi, ki je $\mathrm{v}$ širšem kontekstu prepredena $\mathrm{z}$ radikalno sekularizacijo, diferenciacijo, ideološko fragmentacijo (Zupan Sosič 2011, 150). Artur Pepa je kvazipisatelj, ki ves čas premišljuje, kaj bi napisal, a svoje ideje le stežka ubesedi. Deležen je tudi cenzure, ko je s svojo knjigo hotel prevrednotiti literarni kanon, s sežigom knjige pa je obsojen na javni linč. Rad bi napisal bestseller, želi si ugajati, s tem pa se že približuje polju trivialnosti in podrejenosti, ki ju narekuje sodobna dobičkonosna družbena resničnost. Artur je predstavljen skozi svoja neumna dejanja (zlasti tedaj, ko se zaradi prevare hoče maščevati ženinemu ljubimcu Zumbrunnenu), določajo pa ga tudi povprečni, prazni dialogi. Ima težave $\mathrm{z}$ alkoholom in zaradi pijančevanja resne zdravstvene probleme s srcem. Še stopnjevan kvaziumetnik v romanu je režiser Volšebnik, ki bere in izbira poneumljajoče scenarije za reklamo, vsi pa namigujejo na spolnost in erotičnost. Zanj je pomemben le družbeni status. $\mathrm{V}$ romanu so poudarjeni manipulativni vzgibi, ki bi omogočili izkrivljanje polpretekle literarne zgodovine, pesmi Igorja 
Bogdana Anotniča, ki je ustvarjal na začetku dvajsetih in tridesetih let prejšnjega stoletja in mu Andruhovič nameni šesto poglavje, njegove pesmi pa so smiselno vpete $\mathrm{v}$ roman, so mestoma predstavljene poenostavljeno, poneumljajoče, vse z razlogom, da bi pesnika popularizirale. Volšebnikova pritlehnost je jasno izražena $\mathrm{v}$ njegovih pogovorih $\mathrm{z}$ ostalimi, kjer je očitno, da ni sposoben spregovoriti brez mašil, prekinitev, njegov govor ni dokončan, besedni zaklad pa je na izredno osiromašen. Umetnost je prodal zaradi komercializacije, sledenja trendom in lastnega dobička. Edino upanje za umetnost je Romina hči Kolja, mladoletno dekle, ki razume pomen Antoničevih dvanajstih krogov pomladi in je prijetna sogovornica.

Videti je, da groteskno izvotljenost stopnjuje svet, v katerem so poudarjeni prazni izrazi, hitro, nekritično zadovoljstvo in odsotnost samoobvladovanja. $\mathrm{V}$ postsovjetski resničnosti vidi spremenjeno vlogo umetnosti tudi ugledni ukrajinski pisatelj Andrej Kurkov, in sicer, da je bilo v samostojni državi mogoče »objavljati vse; toda literatura je izgubila svojo vlogo « (Dović 2008, 15). Na to posredno opozarja tudi roman Dvanajst krogov, hkrati pa izpostavlja cenzuro v navidezni svobodi. Arturju Pepi so namreč zaradi njegovih novih pogledov na književnost sežgali eno od njegovih knjig.

Omenjeno je bilo, da se je v neodvisni Ukrajini vzpostavilo okolje za porast oligarhov, ki nadzorujejo gospodarstvo, politiko idr. V romanu je tajkun in oligarh predstavljen v podobi Varcabiča, lastnika letovišča, v katerem so nastanjene glavne literarne osebe, avtomobilskega odpada in beznice. Predstavljen je kot nadčlovek, ki se nikdar ne pojavi, z literarnimi osebami komunicira posredno in mu je dovoljeno vse, ima pa tudi nepredstavljivo moč v vseh porah družbe.

Velik problem današnje Ukrajine je alkoholizem, posledice katerega niso le posameznikov razpad, uničene družine in širše skupnosti, temveč tudi izginotje številnih ukrajinskih vasi. Mnogo Ukrajincem predstavlja popivanje način življenja. V romanu je podano veseljačenje, utapljanje nezadovoljstva $\mathrm{v}$ alkoholu in literarne osebe nasploh veliko pijejo, zlasti Artur Pepa.

V Dvanajstih krogih se pojavi tudi velikanski avtoodpad, lastnik katerega je že omenjeni oligarh Varcabič, ta literarni prostor pa predstavlja metaforo o končnosti dovčerjašjega sveta in/ali začetku nečesa novega. Tam se v zapuščenem avtu znajdeta Artur Pepa in Roma, ki premišljujeta o prihodnosti njune ljubezni in pomenljivosti prostor-časa, $\mathrm{v}$ katerega sta ujeta. Roman še na več mestih poudarja zanemarjenost, umazanost ukra- 
jinskih rek, potokov, $s$ čimer avtor namiguje na resnično perečo težavo, $s$ katero se država sooča. Pomenljivo je, da je bilo leta 1990 v državnih rekah za 19,7 bilijona kubičnih metrov odplak (Boreyko 1993).

Jurij Andruhovič je tudi avtor več esejističnih zbirk, v katerih izpostavljene teme podaja v luči evropske ignorance do Ukrajine in (ne)približevanja Ukrajine Evropi. V esejih iz zbirke Дезорієнтація на місцевості se poglablja v različne teme, zlasti se večkrat dekriptivno navezuje na zunajliterarne topose, na Ukrajino, Lvov, habsburški prostor z vso svojo jezikovno-kulturno barvitostjo, prav tako pa ga zanima podoba umetnosti, umetnika, pri čemer se večkrat obrača $\mathrm{k}$ pesniku Bogdanu Igorju Antoniču, ki mu v Dvanajstih krogih namenja posebno mesto.

\section{Zaključek}

Roman Dvanajst krogov je časovno postavljen v devetdeseta leta, v ukrajinsko samostojnost in neodvisnost ter podaja življenje $\mathrm{v}$ postsocialistični državi. Videti je, da sta posameznik in širša družbena skupnost kljub navidezni svobodi v nanovo ustanovljeni državi še vedno vpeta v preteklost in tradicijo, zato morebitnih sprememb na bolje ni. Še več, življenje takoj po osamosvojitvi v tej državi ni prijetno in ne omogoča dostojnosti, zato se pojavijo številne negativne posledice za skupnost, mdr. migracije, zapuščeni otroci, porast prostitucije, zasidran problem alkoholizma, prav tako pa se vzpostavljajo modificirane oblike starega sistema, kot jih opaža tujec Karl Joseph Zumbrunnen, pa tudi že soočanje s posledicami kapitalizma. Vsevedni pripovedovalec pred bralca večperspektivno predoči neizbežno žalostno usodo države, ki je imela potencial, a ga ni znala ali zmogla izkoristiti.

\section{Viri in literatura}

Andruhovič, Jurij. 2016. Dvanajst krogov. Ljubljana: Cankarjeva založba. Andruhovič, Jurij.1999. Дезорієнтація на місцевості. Лілея - НВ.

Bochi, Angela; Povoroznyk, Vasyl. 2014. "Shadow economy in Ukraine: causes and solutions «. International Centre for Policy Studies: 1-7. icps.com.ua Boreyko, Volodymyr. 1993. »The environment: Pollution plagues large areas of Ukraine«. The Ukrainian Weekly LXI/6. <Http://www.ukrweekly.com/ old/archive/1993/o69303.shtml>. (Dostop 1. 6. 2016.)

Düvell, F., Lapšina, I. »The EuroMaidan Protests, Corruption, and War in Ukraine: Migration Trends and Ambitions«. $<$ Http://www.migrationpol- 
icy.org/article/euromaidan-protests-corruption-and-war-ukraine-migration-trends-and-ambitions $>$. (Dostop: 1. 6. 2016.)

Fisher, Reinis. 2014. »Ukraine vs Poland by GDP 1990-2012«. <Http://www. reinisfischer.com/ukraine-vs-poland-gdp-1990-2012.>. (Dostop: 1.6. 2016.)

Godina, Vesna V. 2014. »Drugi pogled: uvedba antropološke perspektive«. V Vesna V. Godina, Zablode postsocializma, 100-180. Ljubljana: Beletrina.

Hughes, Donna M., Denisova Tatyana. 2003. Trafficking in Women From Ukraine. U. S. Department of Justice.

Janovič, Liza. 2015: »Children Left Behind: The Impact of Labor Migration in Moldova and Ukraine«. <Http://www.migrationpolicy.org/article/ children-left-behind-impact-labor-migration-moldova-and-ukraine $>$. (Dostop: 1. 6. 2016.)

Jaroszewicz, Marta. 2015. "The migration of Ukrainians in times od crisis«. Centre for Eastern Studies 187: 1-8.

$<$ Http://www.osw.waw.pl/sites/default/files/commentary_187.pdf $>$. (Dostop: 1. 6. 2016.)

Kutsyuruba, Benjamin. 2011. »Education in the Period of Post-Soviet Transition in Ukraine«. Democracy. A journal od ideas: 287-309. Winter Issue 2011.

$<$ Https://www2.gwu.edu/ ieresgwu/assets/docs/demokratizatsiya\%2oarchive/GWASHU_DEMO_19_3/J57410H66R1H7404/J57410H66R1H7404. pdf $>$. (Dostop: 1. 6. 2016.)

Levchuk, Natalia. 2009. "Alcohol and morality in Ukraine«. Rostock: MaxPlanck-Institut für demografische Forshung: 1-24.

<Http://www.demogr.mpg.de/papers/working/wp-2009-017.pdf $>$. (Dostop: 1. 6. 2016.)

Malinovska, Olena. 2006. »Caught Between East and West, Ukraine Struggles with Its Migration Policy«. <Http://www.migrationpolicy.org/article/ caught-between-east-and-west-ukraine-struggles-its-migration-policy>. (Dostop: 1. 6. 2016.)

Portnov, Andrij. 2014. »Postsowjetische Hybridität und "Eurorevolution" in der Ukraine - Essay«. <Http://www.bpb.de/apuz/194814/postsowjetische-hybriditaet-und-eurorevolution? $\mathrm{p}=\mathrm{o}>$. (Dostop: 1. 6. 2016.)

»Die unabhängige Ukraine«. 2015. Bundeszentrale für politische Bildung. $<$ Http://www.bpb.de/izpb/209819/die-unabhaengige-ukraine>. (Dostop: 1. 6. 2016.) 
»Die Ukraine - Land mit zwei Gesichtern«. 2014. <Http://www.mdr.de/damals/ archiv/ukraine194.html>. (Dostop: 1. 6. 2016.)

Samokhvalov, A. V., Pidkorytov, V. S., Linskiy, I. V., Minko, O. I., Minko, O. O., Rehm, J., Popova, S. 2009. "Alcohol use and addiction services in Ukraine«. International Psychiatry 6 (1): 5-7. $<$ Http://www.psychiatry.ua/ eng/engo 49.htm>. (Dostop: 1. 6. 2016.)

Sutela, Pekka. 2012. »The Underachiever: Ukraine's Economy Since 1991«.

$<\mathrm{Http}$ //carnegieendowment.org/2012/03/o8/underachiever-ukraine-s-economy-since-1991-pub-47451>. (Dostop: 1. 6. 2016.)

WHO. Ukraine: Alcohol Comsumption. <Http://www.who.int/substance_ abuse/publications/global_alcohol_report/profiles/ukr.pdf>. (Dostop: 1 . 6. 2016.)

Vollmaier Lubej, Janja. 2016. »V temni noči opotekajoči se pijanec«. V Dvanajst krogov, Jurij Andruhovič, 209-220. Ljubljana: Cankarjeva založba.

Zupan Sosič, Alojzija. 2011. »Trivialnost«. Slavistična revija 59/2: 147-160. 



\section{Романите на Толстой и киното Руски и неруски рефлексии}

Константина Пунева / Konstantina Puneva

Софийски университет „Св. Климент Охриски“

Sofia University "St. Kliment Ohridski"

kpuneva@gmail.com

Основен интерес на доклада е съпоставката на руските и неруските екранизации по романите на Толстой („Война и мир“, „Ана Каренина“ и „Възкресение“). Рефератът се фокусира върху универсалните мотиви в екранизациите и приемствеността им през годините. Проблематизирана е и тема за възприемането на руската култура извън пределите на Русия.

Ключови думи: Толстой, романи, „Война и мир“, „Ана Каренина“, „Възкресение“, екранизации, универсални мотиви, рефлексии, обществени нагласи, текст, филм

Tolstoy's Novels and the Cinema. Russian and Non-Russian Reflections

The main intention of the paper is a comparison between the Russian and non-Russian screen adaptations of the novels of Tolstoy (War and Peace, Anna Karenina and Resurrection). The author focuses on the universal motives in adaptation and their continuity over the years. Other key issues include the perception of Russian culture beyond the boundaries of Russia.

Key words: Tolstoy, novels, "War and Peace", "Anna Karenina", "Resurrection", adaptations, universal motifs, reflections, public attitudes, text, film 
Присъствието на Толстой в киното все повече изкушава изследователите и насочва интереса им към екранизациите по великите му романи. Граничната линия между текст и филм, застинало и движещо се изображение, оригинал и екранно копие има особено метафизично проявление, що се отнася до Толстоевите романи. Те предизвикват силен отзвук из целия свят, а първите адаптации се появяват още приживе на автора. При внимателното навлизане в темата няма как да се подмине разграничението руски и неруски рефлексии. Как киноезикът тълкува текста-Толстой в Русия и извън нея? Кои са универсалните мотиви, върху които наблягат режисьорите? Надграждат ли се образите и има ли приемственост между литературния и филмовия им вариант? Достига ли се до същността на концепта, формулиран от Бердяев като „руска душа“? Все въпроси, фундаментални при работата с екранизациите по „Война и мир“, „Ана Каренина“ и „Възкресение“. Бързам още тук да направя уговорката, че в изложението ще се спра само на представителна част от екранизациите. Мащабността на темата не ми позволява да разгърна цялостно проблематиката, затова ще резюмирам фрагментарно основната концепция.

В Русия литературата е органична част от всекидневието, а руският човек респективно е център в творчеството на класиците. В произведенията си те се занимават със събитията и проблемите, вълнуващи съзнанието на обществото, предимно през призмата на руското. В романите на Толстой именно човекът и неговите екзистенциални търсения са основният модус, около който се изгражда сюжетът. На Запад руската културна традиция провокира голям интерес. Но в неруските екранизации често се забелязва невъзможност инстинктивно да се проникне в нея, да се улови атмосферата и да се разрови под повърхността на литературното изображение. В същото време руският човек естествено се потопява и пресъздава усещанията, заложени в романите на Лев Николаевич, защото е носител на същата менталност, върху която се основава собствената му култура.

При адаптирането на романовия материал в сценарий се разминават идеите, заложени в текста, тъй като кинематографистите се стремят да се докоснат до колективното несъзнавано и да накарат зрителя да се самоиндетифицира с главните герои. Тези цели задължават режисьорите да подходят към текста, съобразявайки се с обществените нагласи. От друга страна, многопластовият свят на пи- 
сателя трудно може да бъде цялостно пренесен на филмова лента. Не трябва да забравяме, че „Толстой създава нова естетическа (тоест философско мотивирана) концепция за разбирането и тълкуването на човека“, по думите на руския автор Евгений Костин (Костин 2015: 306). Именно стремежът на автора към описание на живота такъв, какъвто е, човешката същност и обществените отношения, представени възможно най-реалистично и през различни художествени призми, са сред особеностите, придаващи на романите му универсалност и цялостност. Качества, привличащи режисьорите, но и най-проблематични за пресъздаване.

Първият екранизиран роман на Толстой, е „Възкресение“; продукцията е датска. Тук веднага възниква питането защо спонтанният избор на режисьорите не е епическата мощ на „Война и мир“ или социалната и лична драма в „Ана Каренина“, а именно историята на съблазнената и изоставена жена. Сред предпоставките за този избор са частната съдба, силните индивидуалности, психологическите обрати и богатата образност. Отделно, през първите години на киноизкуството технически не е било възможно да се изобразят мащабността и многообразието от характери на предходните два романа. Разбира се, не закъсняват опитите и по тях. Първата филмова разработка на „Ана Каренина“ е немска продукция от 1910 г., а по „Война и мир“ - от 1913 г., дело на руския режисьор Пьотр Чардинин. Фактите показват, че кинематографистите от различни страни се обръщат към творчеството на Толстой още с прохождането на киното. Този интерес не стихва нито за миг и до днес. Актуален пример е последната екранизация на БиБиСи по „Война и мир“ от 2016 г.

Произведенията на писателя намират широк отзвук в целия свят. Обичаните от редица поколения сюжети привличат с нетрадиционния поглед към вечно актуални обществени теми, с общочовешката си проблематика и смелите ракурси на нейното интерпретиране. Посягайки към Толстой, задачата на кинематографистите се улеснява, защото устойчивите черти на героите спомагат за лесното им визуално пресъздаване. От друга страна, съвременният зрител често е „двойно“ запознат със сюжетите. Веднъж от текстовете и втори път от филмите. Така в представата на публиката има предпоставени очаквания, които с всяка нова екранна транскрипция трябва да се надградят. Тези особености са присъщи за всяко литературно произведение, пренесено на екрана, но са особено важни при Толстоевите романи, 
реинкарнирани десетки пъти: факт, допълнително затрудняващ кинотворците. Те трябва да решат дали да доизградят образите, познати от екрана, или да се завърнат към текста и да го представят с напълно нова концепция. Затова по-често се съобразяват със съвременното мислене за литература и кино, а появата на нова екранизация почти винаги се е превръщала в събитие. Сред филмите, превърнали се в етапни, се открояват „Война и мир“ на Кинг Видор (1956), на Сергей Бондарчук от (1965), на Робърт Дорнхелм (2007); „Ана Каренина“ на Кларънс Браун (1935), на Жулиен Дювивие (1948), на Александър Зархй (1967), на Бърнард Роуз от 1997 г., на Сергей Соловьов (2009) и адаптацията на Джо Райт (2012), а останали в историята екранизации на „Възкресение“ са само три - от 1909 г. на Дейвид Грифит, от 1960 г. на Михаил Швейцер и от 2001 г. на братя Тавиани. Това изброяване е необходимо, за да се представи нагледно интересът на режисьорите в Русия и извън пределите ѝ . Девет от изброените общо дванайсет филма са неруски - именно онези, които обикновено биват „обвинявани“, че не успяват да разберат и пресъздадат мирогледа на Толстой към света. Далечни на руската култура, те в повечето случаи, не проникват в руския дух, оставайки на повърхността на наратива.

Наблюдават се няколко общи тенденции, които трябва да се откроят в самото начало. В центъра на филмите, независимо за кой от трите романа става въпрос, на преден план стоят личните драми и взаимоотношения. В първите години от филмографията адаптациите се доближават до мелодраматизма, а главните герои са наивистично пресъздадени. С развитието на езика на киното режисьорите все повече наблягат на различни мотивации в действията и решенията на персонажите. Филмите диалогизират помежду си, като особено интересни са руските отговори на западни екранни версии. За пример могат да послужат филмът на Бондарчук, появил се десет години след успешната американска версия на Кинг Видор от 1956 г., както и опитът на Александър Зархй от 1967 г., полумизиращ с предишните английски и американски продукции по „Ана Каренина“.

По повод американската адаптация на „Война и мир“ Видор Шкловски пише, че тя оставя у руснака чувство за вина, защото не е намерила своята съдържателна екранна версия в Русия. И допълва, че „не трябва да се обръщаш към великите класици заради събитийната част от произведенията им, а за да се научиш от тях как да анализираш живота“ (Шкловский 1985: 287). 
Между филма на Кинг Видор от 1956 г. и екранизацията на Бондарчук от 1965 г. се наблюдава пълно разграничаване в изграждането на образите и тяхната мотировка. Бондарчук се придържа плътно към текста, но в същото време успява да го пренапише на езика на киното. В своята монография Лев Анинский посочва много важен факт за подхода на двамата режисьори: Видор се ориентира и изгражда сюжета според събитията в романа, а Бондарчук следва атмосферата на действието и духа на текста. Интересен факт е, че самият Бондарчук се посвещава изяло на филма. Няколко години той „живее“ със сюжета, изучава „вселената“ Толстой и я разглежда като цялостно явление. Към разработката на образите е подходено с умисъл и внимание към всеки детайл. Изготвят се точни копия на костюми от началото на XIX в., табакери, копчета, нашивки, оръжия и т. н. И Видор, и Бондарчук съзнават, че тематиката на романа няма как да привлече със своята актуалност на събитията ${ }^{1}$, затова трябва да се наблегне на пищните и колоритни балове, спецификата на взаимоотношенията в руското общество в началото на XIX в., индивидуалните черти на героите. В това отношение и двамата успяват да създадат забележителни и завладяващи сцени, които остават в съзнанието на зрителя.

Вглеждайки се в екранизациите на „Ана Каренина“, отново откриваме подобна ситуация през 6о-те години². Александър Зархй прави своя опит не на последно място и като отговор на популярните филми с Грета Гарбо от 1935 г. (първата звукова лента по романа) и Вивиан Лий от 1948 г. Техни режисьори са съответно Кларънс Браун и Жулиен Дювивие. Тук изпъква амалгамата между роман, мит и филмов език. Двете версии се фокусират върху любовния триъгълник Ана-Каренин-Вронски, а Кити и Левин са напълно омаловажени като персонажи. Набляга се на драматизма във взаимоотношенията на основните герои, а критиката към многоликото руско общество е избегната. Героините на Грета Гарбо и Вивиан Лий успяват да изградят силни образи, но при тях липсва експлицитно изведена идеята за греха и последствията от него. Екранизацията от Кларънс Браун пра-

1 Средпредпоставките Бондарчукдаекранизира „Война имир“енаближаващата тогава 150-годишнина от Бородинската битка. Самият филм започва да се снима през 1960 г. Не трябва да се пропуска и желанието от страна на Съветска Русия да отговори на успешната американска версия на Кинг Видор.

2 Именно около 6о-те години се появяват филми с усложнена образност, цялостно представяне на сюжетните линии. 
ви и най-големите размествания спрямо литературното произведение. Тук Вронски е този, който изоставя Ана, за да отиде на фронта, докато в романа героят предприема съдбовната крачка след самоубийството на героинята.

У Зархй експлицитно се открояват редица промени от предходните филми. Адаптацията на режисьора акцентно засяга темата за еманципацията на жената. Според киноведа Лев Анински не Ана (Татяна Самойлова) е „инициатор и източник на драматизма, водещ до нейната гибел“ (Анинский 1980: 325), а първопричина за трагедията е Вронски. Тяхната любов е представена като изблик на страст, която ги повлича към неизбежния край. Вронски, за разлика от адаптацията на Браун, не е изобразен като съблазнител, а като човек, изпитващ необходимост от духовна близост, но и неможещ да я открие.

Следващата важна адаптация на „Ана Каренина“ е американска продукция от 1997 г., в която чувствеността и еманципацията се издигат на съвсем ново ниво. Бърнард Роуз е почерпил вдъхновение от предишните запомнящи се образи на Ана, за да изгради своята концепция за героинята. За разлика от предходните неруски екранизации, филмът изгражда пълноценно персонажите на Левин и Кити, а историята на Ана е представена като по-малко значима „смес от мита за прелюбодейство, литературния текст и неговите филмовия варианти“ (Makoveeva 2007: 105). Екипът се възползва от възможността да заснеме част от сцените в Русия, която не е била достъпна за предишните неруски версии поради комунистическия режим. Стремежът да се пресъздаде руският човек и дух прозират както в местата, костюмите, така и в музиката, подбрана за екранизацията - фонът често е запълнен с Прокофиев, Чайковски и Рахманинов. Роуз реанимира американските адаптации, но както отбелязва изследователката Ирина Маковеева, той се разграничава от клишетата, свързани с руската култура, и подхожда към сюжета, включвайки елементи от високата култура - балет, музика, архитектура, литература. Въпреки това изпълнението на Софи Марсо не успява да засенчи превъплъщенията на Грета Гарбо и Татяна Самойлова.

Първата руска версия след разпадането на Съветския съюз се появява през 2009 г. Неин режисьор е Сергей Соловьов, а в главната роля виждаме Татяна Дубрич. Решенията на екипа тук на места достигат крайности, а по думите на киноведа Геновева Димитрова: „екранният вариант на Соловьов, въпреки обилния оригинален текст и 
ремарките, е ампутиран и от любов, и от Толстоевия полифонизъм“ (Димитрова 2011: 99). В образа на Ана са инфилтрирани голяма доза експресивност и крайни емоционални състояния. Подходът на режисьора донякъде е обоснован от желанието да се разграничи изцяло от предходните силни образи на Ана и да провокира зрителя със своя концепция и мотировка на персонажите. Последната филмова версия на романа е английската продукция на Джо Райт от 2012 г. Тя е важна със своя творчески подход и балансирането между литература, театър и кино. Силните емоции, ревността, всепоглъщащата страст и тук са поставени в центъра на взаимоотношенията между Ана (Кийра Найтли) и Вронски (Аарон Джонсън). Не е изненадващо, че отново, както в адаптацията на Роуз, е подчертано прибягването към опиума. Сексуалността, опияняващите субстанции, еманципацията на жената са теми, които са особено актуални през последните десетилетия. Чрез сюжета на Толстой режисьорите съумяват да развият значими социални теми.

Това твърдение се отнася цялостно и за адаптациите на „Възкресение“. Романът има над двайсет екранни версии, но повечето от тях не са запазени. Към сюжета се насочват режисьори буквално от цял свят - Русия, САЩ, Дания, Франция, Италия, Германия, Индия, Япония, Мексико и др. Първият съхранен филм е на Дейвид Грифит от 1909 г. Актрисата, която изпълнява Катюша, е Фло Лорънс - една от първите кинозвезди в Америка. Екранизацията впечатлява със зрялата си за младото и все още прохождащо изкуство кинематографична мисъл, целенасочената употреба на монтажа, работата с камерата. Богатото разнообразие от образи в романа на Толстой е напълно пренебрегнато, като във версията на Грифит липсват темите за политическата и църковната системи, лицемерието, несъстоятелността на институциите. Режисьорът залага на любовните взаимоотношения и комичните елементи, привличащи интереса на публиката. Във филма на Михаил Швейцер от 1960 г. социалната картина е многостранно изобразена, поставен е акцент върху контраста между бедни и богати, фалша и чистите човешки отношения. Режисьорът внимателно следва повествованието на първата част на романа, като дори се придържа към непрекъснатите ретроспективни връщания на Нехлюдов към миналото. Швейцер акцентира на епизоди, важни за промяната на мирогледа на Димитрий и Катюша. Толстой застъпва тезата, че пред младите има две възможности - да съхранят и разви- 
ят добрите си качества, или да се поддадат на материалните и егоистични навици, водещи до разруха на моралните устои. За руския режисьор последиците от житейските избори са важни и именно те са изведени в екранизацията. Филмът успява да въздейства със своята мрачна тоналност, дълбоки и същностни душевни противоречия, добра актьорска игра и правилно разчитане на Толстоевата ирония към обществените нагласи в произведението.

Накрая ще спра вниманието си върху адаптацията на братя Тавиани от 2001 г. В нея е отделено специално внимание на моментите, в които персонажите са изправени пред силен душевен потрес. Успешно е уловен духът на романа. Забележителна например е трансформацията на Катюша от невинно момиче в зряла и груба проститутка. Стефания Рока и Тимоти Пийч пресъздават достоверно метаморфозите в характерите на Маслова и Нехлюдов, както и силната им емоционална натовареност. Руската душа, нейните падения и въздигания са интерпретирани завидно убедително за една чужда екранизация.

След направения обзор трябва да се посочи и важна особеност, свързана с главните персонажи в произведенията: тенденцията към деконструкция на романовите образи. Режисьорите все по-рядко се съобразяват с авторовите описания (физически и душевни), които са изключително точни, плътни и ярки. Първо виждаме чернокосата и черноока Наташа със сини очи (Людмила Савелиева), а в последствие русокоса (Клеманс Поези и Лили Джеймс). В първите адаптации режисьорите се стремят да уловят нейната замечтаност, бърза смяна на настроенията, детска невинност и постепенно съзряване. В последната версия на „Война и мир“ на режисьора Том Харпър пред нас е една съвсем различна Наташа, поразяваща със своята зрялост от самото начало на мини сериала. Ана Каренина също претърпява редица трансформации - от пищна жена в романа на Лев Николаевич, каквато е представена единствено в адаптацията на Зархй, през по-често фина героиня, за да се стигне до екстремно слабата фигура на Кийра Найтли.

В екранизациите откриваме забележителна дифузия между литература и кино. Периодичното връщане към сюжетите на големите романи на Толстой показват и необходимостта от неговата мъдрост. Актуални и устойчиви теми се оказват чисто човешките емоции, преплитането на съдбите на героите, отстояването на тяхната индивиду- 
алност и борбата им с живота. Дали на фронтовата линия, в балните зали, или в затвора именно проявлението на живота, такъв какъвто е, е универсалният мотив, върху който залагат всички режисьори. Друг подход към големите романи на Толстой не би бил възможен.

\section{Използвана литература}

Анински 1980: $\Lambda$. Анинский. Аев Толстой и кинематограф. Москва

Аимитрова 2011: Г. Аимитрова. Въртележки на абсурда. Руското играхно кино (г99-2огі). София.

Костин 2015: Е. Костин. Аостоевский против Толстого: русская митература и судьба России. СПб

Николски 2009: С. Никольский. Русское мировоззрение. Том II. <http://iphras.ru/pages0746608.htm>. (01.03.2017)

Моковеева 2007: I. Makoveeva. Visualizing Anna Karenina. University of Pittsburgh.

Шкловски 1985: В. Шкиовский. За 60 мет: Работы о кино. Москва

Чернишева 2016: В. Чернышева. Как снимали фимьм "Война и мир" - $\quad$ <https://rg.ru/2016/03/r6/kak-snimali-film-vojna-i-mir.html>. (01.03.2017) 



\section{„Konačno demistificirati Goranovo djelo“: Društveno sjećanje na Ivana Gorana Kovačića}

Tomislav Augustinčić

Filozofski fakultet Sveučilišta u Zagrebu, Odsjek za etnologiju i kulturnu antropologiju Faculty of Humanities and Social Sciences at the University of Zagreb, Department of Ethnology and Cultural Anthropology t.augustincic@gmail.com

U ovom radu autor raspravlja o društvenom sjećanju na književnika Ivana Gorana Kovačića. Autor iscrtava genealogiju reinterpretacije Kovačića započetu izložbom održanom 2003. godine te nekolicini objavljenih tekstova. Ove izvore autor promatra kao vektore sjećanja te promatra na koji način su reinterpretirali figuru sjećanja na Kovačića pod zahtjevom dezideologizacije i demistifikacije diskursa o njemu. Autor ističe kako je ova dezideologizacija bila zapravo ideologizacija u postjugoslavenskoj nacionalnoj ideologiji.

Ključne riječi: Ivan Goran Kovačić, vektori sjećanja, društveno sjećanje, društveno pamćenje

\section{Social Remembrance and Memories of Ivan Goran Kovačić}

In this paper, the author discusses social memories of author Ivan Goran Kovačić. The author sketches a genealogy of the reinterpretation of Kovačić that started with an exhibition that took place in 2003, and a few subsequently published articles. These sources are regarded as vectors of memory, and the author examines how they reinterpreted the features of memories about Kovačić under the demand for a de-ideologisation and demystification of the discourse about him. The author stresses that this de-ideol- 
ogisation was actually an ideologisation in accordance with the code of a post-Yugoslav Croatian national ideology.

Key words: Ivan Goran Kovačić, vectors of memory, social memory, social remembrance

\section{Uvod}

Ivan Goran Kovačić hrvatski je književnik rođen 1913. u Lukovdolu. 1932. godine s Josipom Hitrecem i Vladimirom Jurčićem objavljuje prvu zbirku (izbor iz srednjoškolskih pjesama) Lirika, a 1936. godine objavljena mu je zbirka novela Dani gnjeva. Poeziju je tijekom života objavljivao u književnim časopisima. Kao novinar i urednik kulturne rubrike prvo u Hrvatskom dnevniku a potom listu Novosti, od 1936. godine piše kritike, prikaze, članke, polemike i eseje. Za života je prevodio na hrvatski brojne pjesnike, a osobito se istaknuo prijevodima engleske lirike (LZMK, s.a.). Njegov književni opus obuhvaća, „,sedam novela iz knjige Dani gnjeva, pjesništvo, koje se dijeli na štokavske i kajk. pjesme (Ognji i rože, 1945), poemu Jama (1944) i Hrvatske pjesme partizanke (1943), [...] te mnogobrojne knjiž. i film. prikaze, članke i polemike“ (skraćenice u izvorniku, op. T.A.; LZMK s.a.). Poginuo je 1943. godine, sudjelujući kao partizanski borac u Narodnooslobodilačkoj borbi (dalje: NOB), kraj Foče u Crnoj Gori.

Središnji istraživački interes mojeg diplomskog rada pitanje je suvremenih izraza i izvedbi društvenog sjećanja na Ivana Gorana Kovačića u kontekstu pjesničkog festivala "Goranovo proljeće“.' Cilj je pritom prepoznati, protumačiti i analizirati na koji način se iskazuje sjećanje na Kovačića u vremenskom, prostornom i programskom okviru manifestacije.

Iz prizme etnoloških i kulturnoantropoloških studija društvenog sjećanja, ono se shvaća ne kao podsvjesno, samostalno postojeće sjećanje koje dijele svi članovi zajednice, već kao stavovi o prošlosti koji se manifestiraju u sadašnjosti (Bermanec et al. 2007). Astrid Erll je istaknula kako prošlost nije dana, već mora biti „kontinuirano re-konstruirana i re-prezentirana“, podjednako „što se pamti (činjenice, podaci), ali isto i kako se pamti“ $(2008,7)$. U tom shvaćanju društveno sjećanje izražavaju i izvode različiti društveni akteri, time izražavajući i svoj identitet (Assmann 2006). Ono

Diplomski rad pod naslovom "Goranovo proljeće: mjesto i društveno sjećanje u kontekstu pjesničkog festivala" autor je obranio pri Odsjeku za etnologiju i kulturnu antropologiju Filozofskog fakulteta Sveučilištu u Zagrebu u rujnu 2017. godine. Rad su mentorirale dr.sc. Nevena Škrbić Alempijević i dr.sc. Petra Kelemen, kojima autor zahvaljuje i na savjetima u oblikovanju ovog rada. 
je uvijek konkretno povezano i specifično za vrijeme, prostor i društvenu skupinu/pojedince koji ga manifestiraju (Assmann 2006, Assmann 2008), a koji upirući se o prošlost progovaraju o sadašnjosti (Bermanec et al. 2007). Povjesničarke Maja Brkljačič i Sanja Prlenda naglasile su da su u istraživanju društvenog sjećanja relevantna pitanja „tko se prisjeća, u kojem kontekstu, gdje i nasuprot čega?“ $(2006,13)$. Inherentno je politično zbog selekcije elemenata koji će tvoriti skup sjećanja (Assmann 2008).

Društveno sjećanje Ivana Gorana Kovačića kompleksna je tema s dugom kronologijom i genealogijom ideja koje su oblikovale Ivana Gorana Kovačića kao figuru sjećanja, ${ }^{2}$ a kakva se manifestira danas. Ovaj rad je zahvat $u$ jednu epizodu društvenog sjećanja na Kovačića i iscrtavanje genealogije jedne interpretacije figure sjećanja ovog književnika. Pritom, proces ispisivanja jedne takve genealogije ideja analitički je projekt stvaranja konceptualnog konstrukta, „argument u pojavi otkrića [...] praksa koja, kada je uspješna, otkriva ne samo genetski lanac već epistemološko polje i njegove diskurzivne tvorevine" (Appadurai 1988, 40).

2003. godine, povodom devedeset godina od rođenja i šezdeset godina od Kovačićeve smrti u hrvatskoj kulturnoj i akademskoj sferi odvio se društveni događaj te je objavljeno nekoliko tekstova koje je važno markirati kao točke u genealogiji društvenog sjećanja na njega. Organizirani su sa željom organizatora da se "demistificira“ $i$ „dezideologizira“, tj. re-interpretira i re-valorizira književnokritičko društveno sjećanje na Kovačića. Odabir ovih momenata za ovaj rad je selektivan, „jer je svaka genealogija izbor između stvarno beskonačnog skupa genealogija koje sačinjavaju problem utjecaja i izvora u intelektualnoj povijesti“ (Appadurai 1988, 40). Odabrao sam u radu predstaviti ovu epizoda društvenog Ivana Gorana Kovačića jer se njoj mogu jasno prepoznati društveni i politički procesi u suvremenom hrvatskom društvu i književnosti, mada nisu esencijalne metafore za suvremeno hrvatsko društvo. U ovom radu promatram ih kao vektore sjećanja, koje Henry Rousso definira kao „nositelj[e] sjećanja [...] izvor[e] koji predlaž[u] namjernu rekonstrukciju događaja za društvenu svrhu [...] reprezentacije tog događaja, bilo svjesne ili podsvjesne, eksplicitne ili implicitne (1991, 219). ${ }^{3}$ Kao takvi, u osnovi su performativni, odnosno društveno

2 Jan Assmann definira figure sjećanja kao ishode ideja pojmova i iskustva, karakterizirane konkretnošću, kojima ideje i društvene istine predstavljene u konkretnim oblicima događaja, osoba i mjesta postaju dio individualnog i kolektivnog sjećanja (Assmann 2006, 54)

3 Henry Rousso u istraživanju sjećanja na period Vichyjevske Francuske kao vektore sjećanja razmatra politički diskurs, komemorativne rituale, filmove i historiografije 
sjećanje koje aktualiziraju „dolazi u postojanje u datom trenutku i mjestu kroz specifične vrste memorijalnih aktivnosti“ (Wood 1999, 2).

\section{Mit o Goranu}

Goran Miloradović, u svom članku „Tri pjesnikova groba“ (2013), bavio se tzv. „mitom o Goranu“. U njemu, Miloradović je argumentirao o mistifikaciji, ideologizaciji i političkoj upotrebi „mita o Goranu“ u socijalističkoj Jugoslaviji, a za kojeg tvrdi da se zadržao i do danas u post-jugoslavenskim državama. ${ }^{4}$ Taj „mit“, prema Miloradoviću, djelo je neimenovanih ideologa socijalističke Jugoslavije, a koji je služio u političke i ideološke svrhe integrativnog djelovanja i promoviranja politike bratstva i jedinstva.

Miloradovićev rad nije ni prvi ni zadnji u konstatiranju mitologizacije i ideologizacije Kovačića u kontekstu društvenog sjećanja u socijalističkoj Jugoslaviji. Miloradović je argumentirao kako je „Kovačićev posmrtni lik [...] promovisan u meru moralne i idejne ispravnosti i stvaralačkog kvaliteta“ (ibid, 26) te je postao „simbol mučeništva u ratu protiv okupatora i njegovih pomagača, a njegova smrt je predstavljana kao svesna i principijelna žrtve na oltaru pravde i međunacionalnog pomirenja“ (ibid, 39). Ovaj je mit održavan brojnim vektorima sjećanja: svjedočanstvima, dnevničkim zapisima, rekonstrukcijom smrti i izvještajima o pronalasku groba, književnim tekstovima, komemoracijama itd. (ibid, passim).

Suvremene aktualizacije mita, primjerice, u kontekstu pjesničkog festivala "Goranovo proljeće", ne izražavaju sve diskurzivne razine i koncepte, tj. cjelovit mit koji je ispisao Goran Miloradović. Upravo u kontekstu "Goranovog proljeća", primjerice, naglašava se Kovačićev antifašizam, njegova žrtva i principijelnost uz napomene kako je bio „partizanski borac i pjesnik“.

(1991, 219-296), a Nancy Wood historiografiju, svjedočanstva preživjelih, suđenja, romane i filmove u svojem istraživanju vektora sjećanja poslijeratne traume nakon Drugog svjetskog rata u Europi (1999, 6, passim).

4 „Post-jugoslavensko“ se ovdje uzima kao vremenska odrednica, van fenomena i koncepta postsocijalizma i postjugoslavenskih društava.

5 Iz terenskih bilješki autora s otvorenja "Goranovog proljeća" 18. ožujka 2016. godine. 


\section{Konačno demistificirati Goranovo djelo}

U rujnu 2003. godine objavljen je u časopisu Vijenac članak Josipa Bratulića, "Glas hrvatske raznolikosti“, koji je u kronološkoj perspektivi postavio pripremu za sljedeće događaje. Bratulić, smještajući ga u krajolik rodnog Lukovdola, isticao je kako je Kovačić za života bio „[k]ada se okrenuo jeziku zavičaja [...] glas hrvatske raznolikosti“, te da „svi koji su pratili njegov rad uvažavali su njegovo dijalektalno pjesništvo kao bistro i bogato vrelo hrvatskoga pjesničkoga govora" (Bratulić 2003). Sažetim, ali panoramskim pogledom i prozaičnim crticama o njegovom životu, on je ujedno normalizirao Kovačićev život nacionalnoj ideologiji prihvatljivim, ali neutralnim okvirom (Kovačić je bio žrtva, dok „zločinci“ nisu imenovani) i kontekstualizacijom u krajolik političkih stavova hrvatskih književnika sredinom 20. stoljeća, projicirajući ih u njegovo stvaralaštvo i intimna osjećanja:

[T]ako je u 20. stoljeću, do 1945., najveći broj književnika bio blizak socijalnoj ljevici i Hrvatskoj seljačkoj stranci braće Radić. U ideji pomirljivosti, ali i moralnoj odlučnosti Stjepana Radića, i Ivan Goran Kovačić našao je prostor za svoje umjetničke iskaze, posebice i stoga jer je njegova vezanost za zavičaj, seljački svijet, ali i jezik zavičaja, bila ona jedinstvena harfa umjetničkog iskaza na kojoj je svaki njegov osjećaj davao puninu značenja i zvuka. (Bratulić 2003)

$\mathrm{Na}$ kraju 2003. godine, 11. prosinca u Atriju Palače Hrvatske akademije znanosti i umjetnosti (dalje: HAZU) otvorena je izložba „Ivan Goran Kovačić 1913-1943“, u organizaciji Odsjeka za povijest hrvatske književnosti Zavoda za povijest hrvatske književnosti, kazališta i glazbe HAZU. Izložbu Ivice Matičevića likovno je oblikovao Mario Beusan (Ivaniš 2003). Izložba je otvorena kratkom ceremonijom, s govorima Dubravka Jelčića (tajnika Razreda za književnost HAZU), akademika Ivana Padovana (ondašnjeg predsjednika HAZU), te autora izložbe. Otvorenje je započelo ičitanjem Dragutina Tadijanovića njegove pjesmu posvećenu Kovačiću, a zatvoreno čitanjem prvog pjevanja Kovačićeve poeme Jama (Ivaniš 2003). Govor Dubravka Jelčića te prikaz izložbe od Drage Ivaniša objavljeni su nakon toga u kulturnom dvotjedniku Vijenac, politički desne provenijencije.

Glavnu notu izložbe podcrtao je Dubravko Jelčić svojim govorom (2003), inzistirajući da „potrebno je napokon i konačno demistificirati Goranovo djelo, a to znači prije svega dezideologizirati ga" (ibid.), tj. otkloniti „sve ideološki kondicionirane fraze kojima se u dugom niz godina kitio 
svaki govor o njemu“ (ibid). Izrečen zahtjev za dezideologizacijom podrazumijevao je čišćenje književnokritičkog diskursa o Kovačiću od u njega upletenog ideološkog diskursa, svjetonazora i vrijednosnih pretpostavki. Ideologija nije izričito imenovana kao ona socijalističke Jugoslavije, već je implicirana referencama na prošlost. I likovni postav izložbe svojim je konceptom korespondirao Jelčićevoj poruci:

Izlošci su smješteni u žarkocrvenoj vitrini koja dijagonalno presijeca kvadratični prostor atrija HAZU izlazeći iz njega. [...] takvim je smještanjem izložbene vitrine i likovnim jezikom [njen autor] podcrtao ono zajedničko u nastupima svih govornika na otvaranju - potrebu da Goranovo djelo konačno izađe iz ideoloških okvira koji su ga okruživali proteklih desetljeća. (Ivaniš 2003)

Prema Ivanišu (2003), vitrina je nudila panoramu od dvadeset i jednog izloška, koji su kao autentični artefakti progovarali o Kovačiću. Nakon svojevrsnog uvoda, kratke kronologije Kovačićevog života i rada, izloženi artefakti su podijeljeni prema tematskoj podjeli „Lukovdol, Karlovac Zagreb, partizani“ (Ivaniš 2003), a autori izložbe naglasak su stavili „na upoznavanje posjetitelja sa stvaralački najplodnijim, zagrebačkim razdobljem Goranova [...] životnog puta, ne zapostavivši pritom ni posljednje mjesece provedene u partizanima“ (ibid.). Postav je naglašavao Kovačićev život i književno stvaralaštvo, kao i kasnije kreativno stvaralaštvo inspirirano njime, poput skulptura Vanje Radauša i Vojina Bakića ili manifestacije "Goranovo proljeće“ (Ivaniš 2003). Mada je uključila Kovačićevo sudjelovanje u NOB-u, čini se da izlošcima izložba nije pretjerano naglašavala njegovu smrt niti ratno sudjelovanje. Danas sačuvane fotografije Kovačićevog sudjelovanja u NOB-u, poput onih u Memorijalnom muzeju u Lukovdolu, ne prikazuju ga u borbi ili s oružjem (v. Dautbegović 2003).

Kovačićeva smrt, pak, bila je neizostavni dio govora Dubravka Jelčića, te je uz izložbu o njegovu životu i stvaralaštvu kao svojevrsnoj bazi, bila polazišna točka za izricanje i kritiziranje jugoslavenske mistifikacije i ideologizacije ovog književnika i podizanje egide za izlazak iz okvira socijalističkih „kondicioniranih fraza“. Premda se govorilo o dezideologizaciji, sama izložba u Atriju HAZU Jelčićevim je govorom bila ideologizirana. Iskorak iz socijalističkih okvira bio je korak u novu ideologizaciju obogaćivanjem povijesnih činjenica i jezgrovitih biografskih crtica vizijama značaja Kovačića za samostalnu i postjugoslavensku Hrvatsku, u kojoj Kovačić nije „veliki pjesnik revolucije“ $\mathrm{i}$ simbol jugoslavenskog „bratstva i jedinstva“ 
(Miloradović 2013) već višestruka „žrtva“ (Jelčić 2003): žrtva Drugog svjetskog rata, socijalističkog režima, žrtva za hrvatsko državno osamostaljenje i u borbi protiv agresora.

Dubravko Jelčić u svom je govoru ponovio nekoliko ključnih ideja i naracija o Kovačićevoj smrti koje su ga konkretizirale i otvorile prostor za interpretaciju u kontekstu njegova značaja za samostalnu, postjugoslavensku Hrvatsku. Ispisivanje tog značaja omogućeno je konstatacijom da je umro među ili u partizanima, a ne kao partizanski borac.

Narativi o Kovačićevoj smrti inače predstavljaju središnje, konkretne pojmove i događaj koji čine figuru sjećanja u individualnom i društvenom sjećanju (usp. Assmann 2006, 54) na ovog književnika. Nicola Watson istaknula je važnost karaktera smrti autora - „u mitovima mnogih pjesnika smrt je suštinski slučajna, dok je kod drugih konstitutivna“ $(2006,38)$. No dok je izložba spominjala samo njegovu smrt, Jelčićev govor referirao se i na njegovu smrt (da je umro kao žrtva četničkog noža) i posthumnu sudbinu (da je „nepoznatog groba“).

Prema Jelčiću, Kovačić „prije svoje tragične smrti profetski je zamislio svoj grob 'u planini mrkoj'“, „[ž]elja mu se ispunila i više nego što je predviđao: njegov grob je i danas nepoznat i ne može do njeg doći ni 'prijatelj drag $^{\prime \prime \prime}$, „[p]ao je tragičnom, a nije pretjerano reći i mučeničkom smrću, žrtvom četničkog noža“ (Jelčić 2003). ${ }^{6}$ Citati kojima je Jelčić obogatio tekst iz Kovačićeve su pjesme Moj grob, objavljene 1937. u novinama Hrvatska revija, uz poemu Jama vjerojatno najpoznatije Kovačićeve pjesme. U njoj, lirski subjekt izražava želju da mu „u planini mrkoj“ bude grob, koji bi bio zarastao i nedostupan svima (pa i pokajničkom glasu, strahu obraćenika, molitvi za spas itd.), a koji nitko ne bi posjećivao, osim draga prijatelja koji bi čak onda prikrio dokaze svojeg posjeta.

Smrt i nepoznat grob konstitutivni su za naraciju o Kovačiću kao pjesniku koji umire kao žrtva u borbi za ideale. Njegovoj poeziji, a osobito njegovim kapitalnim pjesmama Moj grob i poemi Jama, njegova smrt daje konačni smisao (Jergović 2012). U kontekstu izložbe i Jelčićevog govora karakter njegove smrti davao je smisao društvenom sjećanju ne samo njegova života već i šire hrvatske povijesti. Jelčić je argumentirao kako Kovačića njegova smrt „Zauvijek izjednačuje s tisućama Hrvata, koji su jednako stra-

6 U ranijem broju Vijenca iz rujna 2003, Bratulić je također da Kovačićeva je smrt „tragična smrt“, a „[k]ao što je opisao zločin, tako se zločin sručio na njegovu glavu. Kao što je prorokovao sebi grobni hum 'u planini mrkoj'“ (Bratulić 2003). 
vičnom smrću i od istog neprijatelja završili i u Domovinskom ratu."(Jelčić 2003). Štoviše,

Time se, zajedno s njima, [Kovačić] pridružio beskrajnoj povorci žrtava, što ih je tijekom stoljeća Hrvatska podnijela tražeći na sve strane putove za svoj spas, povorci onih kojima je Hrvatska bila (i jest) sinonim ljepote i dobra, slobode i pravednosti. (Ibid)

Ovo je pratilo i izricanje Kovačićeve biografije, normalizirane u nacionalnom ključu, kao i selektivno osporavanje drugačiji, premda implicitno izrečenih interpretacija. Prema Jelčiću, Kovačić tako nije bio samo žrtva četničkog noža, već i žrtva manipulativnog režima koji su nakon njegove smrti istu zloupotrebljavali i iskrivljavali -

A nije ni mogao [predvidjeti zabludu], jer nije imao pred sobom idealiste kakav je bio i samo nego podmukle varalice, koji su njegove [...] plemenite ideale zlorabili za svoje ideološki okrutne ciljeve. [...] Pjesnik zanesen vječnim idealima slobode i pravde, idealima uznesenim do razine apsoluta, bio je prevaren od onih kojima je povjerovao, a od tih ideala bili su daleko isto toliko koliko i oni kojima se suprotstavio. Dok su ti lažni slobodoljubci i pravdonosci farizejski gradili mit i legendu o 'velikom pjesniku revolucije' skrivali su i tajili njegovu hrvatsku dušu i hrvatsku svijest [...] Bio je to cinizam tirana, uvjerenih u svoju apsolutnu vlast, koja im daje pravo da manipuliraju svojim naivnim pristašama. (Jelčić 2003)

Jelčićev naglasak, pritom, nije bio toliko na veličanju Kovačićeve žrtve, jer ona ostaje čista i principijelna, već na isticanju zlouporabe (socijalističkog) režima i ispravljanju nepravde.

\section{Stara štiva, nova čitanja}

I Bratulić i Jelčić naglašavali su visoku kvalitetu Kovačićevog stvaralaštva. Bratulić je naglasio da je Kovačić

svojem i tuđem književnom poslu pristupao [...] veoma ozbiljno, upravo strogo, i uvijek sustavno [...] Upravo je u Jami [...] usuprot zlu i nečovještvu uporabio strog govor kompleksne pjesničke forme poeme. (Bratulić 2003) 
Jelčić je tu kvalitetu argumentirao pozivajući se na svoje ranije radove, da bi, kako je sam istaknuo, „potvrdio stalnost svojih sudova o njemu“:

bio je pjesnik visokih estetskih kriterija i njima primjerenih ambicija. Odlikovao se visokom poetskom imaginacijom i još većom stvaralačkom disciplinom. Nije bio pjesnik-trenutnog nadahnuća, nije bio pisac-improvizator nego strpljivi, mukotrpni tragalac za pravom riječju i promišljeni graditelj svake rečenice. (Jelčić 2003)

Oba autora nisu pristupali ponovnom čitanju i vrednovanju književnog stvaralaštva Ivana Gorana Kovačića. I za Jelčića i za Bratulića Kovačićev status u hrvatskom književnom kanonu je neprijeporan.

Prema Jelčiću, demistifikacija i dezideologizacija nije imala (eksplicitne) političke svrhe. Konačna svrha „čišćenja“ diskursa o Kovačića od ideološki kondicioniranih fraza bila je konačna objektivna i ideološki nepristrana književnokritička valorizacija - „kad otklonimo sve ideološki kondicionirane fraze [...] kritički ga prosuđujući, njegovo će djelo tek tada izaći pred nas u svojoj autentičnosti i tek tada sinut će u svojoj realnoj i nekrivotvorenoj veličini i ljepoti“ (Jelčić 2003). Dakle, konačno objektivno čitanje samo bi potvrdilo Kovačićev status u hrvatskom književnom kanonu.

Svojevrstan odgovor na ovaj poziv stigao je 2015. u kritičkom tekstu Cvjetka Milanje. Nasuprot nacionalnom ideologijom nabijenim govorima iz 2003. godine, Milanja je izricao objektivnost argumentirajući višestruko mistificiranje Kovačića: „[e]vo jedne tragične sudbine, oko koje su, a posteriori, nicale različite mistifikacije, kada je bila riječ o njegovu književnom djelu, a slično i životu, te nadalje ideološkim opredjeljenjima" (Milanja 2015). Čitav rad sažeto je i rigorozno kritičko „novo čitanje“ „starog štiva“ Ivana Gorana Kovačića. Strukturom, redoslijedom analize i, donekle, zaključcima Milanja se ne odmiče suviše daleko od ranijih analiza Vlatka Pavletića, ${ }^{7}$ inzistirajući na tome da pojedina, markantna djela interpretira u kontekstu cjelokupnog Kovačićevog stvaralaštva, a ne biografije. Milanja je tako upozorio „na glasovitu mistifikaciju glede pjesme Moj grob, kao nagovještaj vlastite smrti“ (2015). Za Milanju Kovačić je bez prijepora poeta faber, stvaraoc. U tome, Kovačić je prije svega pannaturist, a na tragu Pavletićevih teza, Milanja će istaknuti vitalizam kao pjesničku strategiju u Kovačićevom stvaralaštvu koje bogato tematizira smrt:

7 Akademik Vlatko Pavletić (1930-2007), teoretičar književnosti, kritičar, esejist i političar autor je više knjiga o Ivanu Goranu Kovačiću, urednik i izbornik više izdanja i pretisaka Kovačićevih sabranih djela, a dugi je niz godina bio u organizaciji pjesničkog festivala "Goranovo proljeće".. 
Inače su horibilni motivi, u skladu s tim, proizvod legendizacije, mitopoetizacije, potkrijepljene vjerovanjima, bajkama, pričanjima iz usmene narodne predaje, što indirektno dokazuju i neke Goranove pjesme 'na narodnu' [...] Pritom valja imati na umu da Goran takovrsne motive rabi kako bi dekorirao neki događaj ili lirski 'proniknuo' u prirodu, čemu su dokaz i druge pjesme (Mračno doba). (Milanja 2015)

Tako, prema Milanji, ni Jama nije Kovačićevo predviđanje zločina koji će mu se sručit na glavu (Bratulić 2003), ni predviđanje vlastite tragične sudbine (Jelčić 2003), pa čak ni

ovdje [u Jami] nije riječ o izravnom 'odrazu' zbilje, nego je riječ o kognitivnim radnjama koje selekcioniraju, reduciraju, rekonstruiraju, pa dakle i konstruiraju tuđe iskustvo na osnovi kojega se proizvodi poemični pripovjedni plan, pa je dakle riječ o iskazu 'rezonera' koji nudi 'svoju' verziju događaja, svoju ideologiju i svoju estetiku'. (Milanja 2015)

Milanjina kritika i ponovno čitanje nije značajno doprinijelo izmještanju ili premještanju, tj. (re/de-)valorizaciji Kovačića u kontekstu hrvatskog (nacionalnog) književnog kanona, već se postavilo kao sveobuhvatna (re-) konstatacija njegovog nepromijenjenog statusa. Pa ipak, u kronologiji ove epizode djelovalo je kao konačni obol pokušaja reinterpretacije Kovačića, nakon njegove demistifikacije i dezideologizacije. Štoviše, Milanjin naglasak na osporavanju mistifikacija pojedinih djela u Kovačićevom književnom stvaralaštvu ostavlja dojam konačnog pečata razrješavanja "starih" mitova, barem na književnokritičkoj razini.

\section{Zaključak}

Vektori sjećanja, kako je u svojoj knjizi pokazala Nancy Wood (1999 passim), mogu biti povod širokim društvenim raspravama i prijeporima o povijesnim epizodama, društvenim kategorijama i shvaćanjima vezanima uz društveno sjećanje, kao i ponovnim evokacijama prošlosti. Ipak, u ovom radu istaknuta epizoda iz kronologije društvenog sjećanja na Kovačića, koliko sam uspio saznati, nije pokrenula značajnije društvene prijepore ni rasprave.

Goran Miloradović ukazao je kako je „[p]romena vladajuće ideologije otvorila [...] mogućnost da se pokuša promena svrhe mita" $(2013,41)$, te da danas ,usled promenjenog istorijskog konteksta on sada ometa formiranje konsenzusa oko slike prošlosti i otvara nove društvene i političke pode- 
le“ (ibid). S jedne strane, radi se o interpretacijama Kovačićevog književnog stvaralaštva (osobito poema Jama), a s druge istovremenoj interpretaciji njegovog života i književnog stvaralaštva gdje se u interpretaciji jedno nameće drugom u iskazivanju jedne šire vizije Kovačićeva života i stvaralaštva u ideološkim okvirima.

Jelčić je, primjerice, naraciju o Kovačićevoj žrtvenoj smrti kao usporedbi za žrtve u borbi za Hrvatsku u Domovinskom ratu već ranije argumentirao u svojim pregledima hrvatske književnosti (Jelčić 1997, 265). ${ }^{8}$ Izložba iz 2003. i tekstovi objavljeni te godine, prikazani u ovom radu, kao vektori sjećanja koji su performativno reinterpretirali događaj i ličnost Ivana Gorana Kovačića bili su iskorak iz akademske sfere rasprave o Kovačiću u (barem idejno) šire društvo, iz disciplinski omeđenog društvenog sjećanja u šire društveno sjećanje.

Cilj je ovog rada bio prikazati mehanizme društvenog sjećanja u jednoj epizodi kronologije društvenog pamćenja na Ivana Gorana Kovačića, tj. rada i performativne prakse oblikovanja, strukturiranja i reorganiziranja onih povijesnih epizoda, događaja i osoba što čine društveno sjećanje (Brkljačić i Prlenda 2006). U tom smislu izložba Ivan Goran Kovačić 19131943, održana u prosincu 2003. godine i povodom nje objavljeni tekstovi u časopisu Vijenac dali su konkretnu reinterpretaciju Kovačića. Uzdižući egidu demistifikacije i dezideologizacije Kovačića i njegovog stvaralaštva, činili su to sa zahtjevom da se tek oslobođen ideoloških okvira Kovačić i njegovo stvaralaštvo mogu konkretno, objektivno i iskreno valorizirati u hrvatskom književnom kanonu. Kao i isticanje mistificiranja Kovačića, i ovaj zahtjev za objektivn(ij)om interpretacijom i valorizacijom Kovačićevog stvaralaštva bio je prisutan u socijalističkoj Jugoslaviji, no izložba iz 2003. i ponajviše Jelčićev tekst izricali su ga u kontekstu osamostaljene i postjugoslavenske, nacionalne Hrvatske. Ovaj je pregled u jednom smislu manjkav utoliko što iz ograničenja forme i opsega nije bilo prostora za raspravljanje upravo o društvenom sjećanju na Kovačića u socijalističkoj Jugoslaviji i širem suvremenom hrvatskom kontekstu s kojim su se autori izložbe i govora/tekstova razračunavali.

U kontekstu izložbe i govora koji su činili njezino otvorenje, dakle, život i stvaralaštvo Ivana Gorana Kovačića reinterpetiralo se s dvije strane: s jedne, izložba je svojim isticanjem Kovačićevog zagrebačkog stvaralaštva

8 Goran Miloradović $(1999,41)$ Jelčićevu tvrdnju da je Jama inspirirana četničkim pokoljima Hrvata u Hercegovini početkom NDH naziva grubim i direktnim pokušajem reinterpretacije mita. 
postavilo osnovu za evokaciju Kovačića kao (produktivnog) književnika. Dubravko Jelčić naglašavao je Kovačićevu posthumnu sudbinu, interpretirajući je kao žrtvu u kontekstu nacionalno obojenih vizija hrvatske prošlosti i sadašnjosti. Kovačićeva biografija je "normalizirana“ za te vizije, pa je on, primjerice, sudjelovao u borbi među partizanima, a ne bio partizan $\mathrm{u}$ NOB-u sa socijalističkim političkim i društvenim stavovima. Izložba i govori potvrdili su njegov položaj u hrvatskom nacionalnom književnom kanonu. U tom smislu reinterpretacije Kovačićevog života i smrti služile su kao biografska potvrda, ispravljanje „zabluda“ o tom hrvatskom književniku. Ni opsežno novo „čitanje“ Kovačićevog cjelokupnog stvaralaštva u članku Cvjetka Milanje nije izmjestilo Kovačića iz književnog kanona, već ponudilo djelomično nove interpretacije u svrhu konačne demistifikacije određenih djela u njegovom književnom opusu. Inzistirajući na detaljnom čitanju i interpretaciji Kovačićevog stvaralaštva kroz samo stvaralaštvo, Milanja je njegove tekstove izmjestio iz disciplinske politizacije i ideologizacije.

Ova reinterpretacija ipak nije u značajnoj mjeri utjecala na promjenu kompleksne i bogate figure sjećanja Ivana Gorana Kovačića, ponajviše zbog toga što je u suvremenom hrvatskom društvu ono tek jedan prostor manifestacije društvenog sjećanja i rada na njemu.

\section{Literatura}

Assmann, Jan. 2006. „Kultura sjećanja“. U Kultura pamćenja i historija, ur. Maja Brkljačić i Sandra Prlenda, 45-77. Zagreb: Golden Marketing Tehnička knjiga.

Assmann, Aleida. 2008. "Canon and Archive". U Cultural Memory Studies, ur. Erll Astrid i Ansgard Nünning, 97-108. Berlin - New York: Walter de Gruyter.

Bermanec, Krešimir, Mario Katić, Tomislav Oroz i Nevena Škrbić Alempijević. 2007. „Sjećanje na Viški boj: proslave, spomenici, naracije“. Studia ethnologica Croatica 19 (1): 77-125.

Brkljačić, Maja i Sandra Prlenda. 2006. „Zašto pamćenje i sjećanje?“. U Kultura pamćenja i historija, ur. Maja Brkljačić i Sandra Prlenda, 9-18. Zagreb: Golden Marketing - Tehnička knjiga.

Dautbegović, Jozefina. „'Osvijetljeno polje' krajnjeg efekta. Novi stalni postav Memorijalnog muzeja Ivana Gorana Kovačića u Lukovdolu“. Informatica museologica, 34 (1-2): 50-54. 
Erll, Astrid. 2008. „Cultural Memory Studies: An Introduction“. U Cultural Memory Studies, ur. Erll Astrid i Ansgard Nünning, 1-17. Berlin - New York: Walter de Gruyter.

Jelčić, Dubravko. 1997. Povijest hrvatske književnosti: tisućljeće od Baščanske ploče do postmoderne. Zagreb: Naklada Pavičić.

Miloradović, Goran. 2012. „Tri groba jednog pjesnika. Smrt Ivana Gorana Kovačića: činjenice, interpretacije, mit“, ur., Drago Roksandić i Ivana Cvijović Javorina. Zagreb: Filozofski fakultet, Centar za komparativnohistorijske i kulturne studije.

Rousso, Henry. 1991. The Vichy Syndrome: History and memory in France since 1945. Cambridge - London: Hardvard University Press.

Watson, Nicola J. 2009. The Literary Tourist. Readers and Places in Romantic and Victorian Britain. Basingstoke - New York: Palgrave Macmillan.

Wood, Nancy. 1999. Vectors of memory: legacies of trauma in postwar Europe. Oxford: Berg.

\section{Elektronički izvori}

Bratulić, Josip. 2003. „Glas hrvatske raznolikosti“. 18.9.2013. Vijenac - Matica Hrvatska. <Http://www.matica.hr/vijenac/249/Glas\%2ohrvatske\%20 raznolikosti/>. (Pristup 26.3.2016.)

Ivaniš, Goran. 2003. „Razbijanje okvira“. Vijenac - Matica Hrvatska. 25.12.2003. <Http://www.matica.hr/vijenac/256/Razbijanje\%2ookvira/>. (Pristup 26.3.2016.)

Jelčić, Dubravko. 2003. „Iznad stvarnosti. Riječ na otvaranju izložbe 'Ivan Goran Kovačić'. 25.12.2003. Vijenac - Matica Hrvatska. <Http://www. matica.hr/vijenac/256/Iznad\%2ostvarnosti/>. (Pristup 26.3.2016.)

Jergović, Miljenko. 2012. „Ivan Goran Kovačić: Oči na dlanu“. 6.10.2012. Osobna internetska stranica. <Http://www.jergovic.com/subotnja-matineja/ivan-goran-kovacic-oci-na-dlanu/>. (Pristup 26.3.2016.)

Milanja, Cvjetko. 2014. „Ivan Goran Kovačić - pannaturist“. Hrvatska revija - Matica Hrvatska. <Http://www.matica.hr/hr/434/Ivan\%2oGoran\%20 Kova\%C4\%8Di\%C4\%87\%20\%E2\%80\%93\%2opannaturist/>.

(Pristup 26.3.2016.) 


\section{Enciklopedijski izvori}

„Kovačić, Ivan Goran“. (s.a.) Leksikografski zavod Miroslav Krleža, Portal znanja <Http://www.lzmk.hr/hr/izdanja/natuknice/12o-hrvatska-enciklopedija/1288-kovacic-ivan-goran>. (Pristup 26.3.2016.) 


\title{
Derivacija glagola sa osnovama stranog porekla u srpskom jeziku u svetlu (ne)jasne diferencijacije između srpskog i hrvatskog standarda ${ }^{\mathrm{I}}$
}

\author{
Mirela Ivanić, Jelena Perišić \\ Faculty of Philosophy, Department of Serbian Language and Linguistics, Novi Sad \\ mirelaivanic25@gmail.com \\ jelenaperisic91@hotmail.com
}

Predmet ovog rada su glagoli čije su tvorbene osnove uglavnom stranog porekla i na njih se prilikom derivacije u srpskom jeziku dodaju sufiksi -ova-, -isa- ili -ira-. Cilj je provera usklađenosti utvrđenog stanja sa srpskim standardom, odnosno da li se derivacija vrši u skladu sa utvrđenim normama srpskog standardnog jezika, ima li uticaja hrvatskog standarda i da li uopšte postoji jasna granica među dvama standardima u ovom njihovom segmentu. Najpre će se predstaviti norme koje propisuju savremeni srpski i hrvatski jezik, a zatim sa njima uporediti stanje utvrđeno na osnovu rezultata analize. Rezultati će se uporediti i sa ranijim zaključcima u vezi sa ovom temom, kako bismo utvrdili da li je došlo do nekih promena. Korpus za analizu čine informativni tekstovi iz srpskih nedeljnih novina.

Ključne reči: glagoli, strane osnove, sufiksi, derivacija, srpski i hrvatski standard

1 Ovaj rad je deo projekta Standardni srpski jezik: sintaksička, semantička i pragmatička istraživanja (178004), koji finansira Ministarstvo prosvete, nauke i tehnološkog razvoja Republike Srbije. 
The Derivation of the Verbs with Generative Bases of Foreign Origin in the Serbian Language in the Light of (Un)clear Differentiation between the Serbian and Croatian Standard

The paper deals with verbs whose generative bases are mostly of foreign origin and their derivatives are added suffixes -ova-, -isaor -ira- from Serbian. The aim is to check the compliance of the established situation with Serbian standards, that is, whether the derivation is performed in accordance with established norms of Serbian standard language, is there any influence of Croatian standards and whether there is a clear distinction between these two. At first, we will introduce the norms prescribed by the contemporary Serbian and Croatian languages and then compare them with the situation established on the basis of the analysis results. The results will then be compared with earlier conclusions on this subject in order to determine whether there have been any changes. The corpus for analysis consists of informative texts from a Serbian weekly magazine.

Key words: verbs, foreign bases, suffixes, derivation, Serbian and Croatian standard

\section{Uvod}

Adaptirani glagoli iz drugih jezika predstavljaju neizostavan deo leksičkog sistema gotovo svakog jezika, pa tako i srpskog. Načini tvorbe takvih glagola i najfrekventniji sufiksi pomoću kojih se izvode značajni su i za izvorne govornike srpskog jezika, ali i za one koji srpski jezik uče kao strani. Stoga, predmet ovog rada jesu glagoli čije su tvorbene osnove uglavnom stranog porekla i na njih se prilikom derivacije u srpskom jeziku dodaju sufiksi -ova-, -isa- ili -ira-.

Cilj ovoga rada jeste provera usklađenosti utvrđenog stanja sa srpskim standardom, odnosno stepen varijabilnosti, tj. stabilnosti u procesu tvorbe glagola iz navedene grupe, i konačno, ispitivanje postojanja jasne granice među dvama standardima u ovom njihovom segmentu.

U skladu sa postavljenim ciljem, najpre će se predstaviti norme koje propisuju savremeni srpski i hrvatski jezik, a zatim sa njima uporediti stanje utvrđeno na osnovu rezultata analize. Rezultati istraživanja će se uporediti i sa ranijim zaključcima u vezi sa ovom temom - iz perioda posto- 
janja srpskohrvatskog jezika i neposredno nakon njegove podele na srpski i hrvatski standard, kako bismo utvrdili da li je došlo do nekih promena.

Korpus za analizu čine informativni tekstovi iz srpskih nedeljnih novina. U pitanju su Nedeline informativne novine (NIN), tačnije četiri broja ovog nedeljnika: od 14. jula (broj 3420), 21. jula (broj 3421), 25. avgusta (broj 3426) i 1. septembra 2016. godine (broj 3427).

Što se metodologije tiče, u radu će se koristiti komparativna, analitička i statistička metoda. Komparativna metoda će biti zastupljena prilikom upoređivanja dvaju standarda (srpskog i hrvatskog), kao i prilikom poređenja rezultata istraživanja sa pravilima jednog i drugog jezika, ali i sa ranijim zaključcima u vezi sa ovom temom. Analitička metoda će se koristiti prilikom analiziranja korpusa, a statistička prilikom prikazivanja rezultata - brojčani i procentualni podaci u vezi sa zastupljenošću sufiksa u korpusu, kao i u vezi sa poreklom osnove od koje su glagoli derivirani.

Teorijski okvir čine srpske i hrvatske gramatike, radovi eminentnih autora povezani sa temom ovog rada, kao i rečnici jednog i drugog jezika. Osnovni izvor podataka o poreklu osnova i propisanim oblicima glagola u srpskom jeziku predstavlja Leksikon stranih reči i izraza Milana Šipke i Ivana Klajna.

\section{Derivacija glagola sa osnovama stranog porekla u ranijim istraživanjima}

Pre nego što se pristupi istraživanju, osvrnućemo se na ranije teorijske postavke, istraživanja i rezultate dobijene na materijalu srpskog/hrvatskog, odnosno srpskohrvatskog jezika, u vezi sa ovim problemom. Istraživana problematika izložiće se tako što će se sagledati normativni status posmatranih glagola u preskriptivnim relevantnim gramatikama (Hrvatska gramatika, Gramatika srpskog jezika) i priručnicima standardnog srpskog i hrvatskog jezika, s ciljem da se ustanovi stepen poklapanja, odnosno razlikovanja registra posmatranih glagola. Da bi se upotpunila slika mogućeg diferenciranja, predstaviće se osnovni rezultati istraživanja koji su za predmet imali tvorbu glagola s osnovama stranog porekla.

U gramatikama se glagolski sufiksi navode najčešće bez infinitivnog nastavka -ti i sve u želji da se sufiksi jasnije odvoje od infinitivnog nastavka i da se bolje diferenciraju među sobom. Međutim, ovakvu logiku gramatičari nikad ne primenjuju na druge vrste reči. Tako, na primer, kako Klajn navodi, u gramatici Stanojčić-Popović $(2002,160)$ skrivati, zagrađi- 
vati, zadobivati dati su kao primeri za sufiks -iva-, „bez napomene da to -iva- kod jednih glagola ostaje i u prezentu, dok kod drugih prelazi u -uje-“ (Klajn 2003, 323). U našem korpusu evidentni su primeri različitih glagolskih vidova, pa u tom smislu možemo govoriti o sufiksima za perfektivizaciju i imperfektivizaciju. Kako Klajn kaže, gramatike ih tretiraju kao i ostale sufikse, s tim što ih svrstavaju pod „glagole izvedene iz glagola“. Samim tim se nameće pitanje da li je nesvršeni glagol zaista „nova“ reč u odnosu na svršeni. Srpska leksikografska praksa pokazuje da to nije tako jer Rečnik Matice srpske (RMS), kao i većina drugih rečnika, upućuje na nesvršeni, odnosno učestali glagol u odnosu na odgovarajući svršeni. Potvrđuje se da svršeni i nesvršeni glagoli nisu posebne lekseme, budući da se međusobno ne razlikuju po značenju, nego samo po gramatičkom obeležju aspektualnosti. Zanimljivo je pogledati kako ovom problemu pristupa Hrvatska gramatika (Barić i dr. 1997). U njoj su vidski parovi obrađeni u dva poglavlja (Morfologija i Tvorba riječi). Upravo u prvom poglavlju nailazimo na termine perfektivizacija i imperfektivizacija, koja se smatra jednom od mehanizama tvorbe, i to takav kojim se generišu različiti tipovi nesvršenih glagola od kojih jedan ima sufiks -a- (sjesti - sjedati) (Barić i dr. 1997, 372).

O sufiksima koji su predmet ovog rada pisao je Petar Skok pedesetih godina prošlog veka. Ovaj autor iznosi da su, od triju sufiksa, dva stranog porekla. Naime, -isati, kojem je središte Beograd, potiče od grčkog aorista - od grčkih denominala na -izo, aorist -isa. Mišljenje autora je da je ovaj sufiks u turcizmima, isto kao i u bugarski, i u naš jezik ušao preko cincarskog govora (u cincarskom se dodaje grčki denominalni sufiks -izo, aorist -isa na turske glagolske osnove) i balkanska je jezička pojava. Na zapadu, čije je središte Zagreb, ustalio se sufiks -irati od nemačkog infinitiva na -ieren, a taj od francuskog infinitiva na -er koji potiče od latinskog -are ili od franscuskog na -ir, a on vodi poreklo od latinskog -ire, dok je sufiks -ovati naša baština iz praslovenskog jezika (Skok 1955-56). Ivan Klajn (2003, 339) slaže se sa Skokom što se porekla sufiksa tiče, s tim što za sufiks -isa(ti) navodi da je grčkog porekla, ali se u srpskoj derivatologiji svrstava pre u domaće nego u strane sufikse. Ističe da se on upotrebljava sa mnogim stranim glagolskim osnovama koje u hrvatskom (katkad alternativno i u srpskom) imaju -irati, ali dolazi i na domaće osnove (ugljenisati), u odomaćenim grecizmima (mirisati, metenisati), kao i u starim turcizmima (begenisati, kaldrmisati). O poreklu ovih sufiksa govori i M. Jocić i slaže se sa navedenim autorima. Dodaje da se sufiks -isa- prvi put javlja na istoku naše jezičke teritorije u pozajmicama iz grčkog jezika u XII veku, počev od XVII veka 
sve više se vezuje za turske pozajmice u srpskohrvatskom jeziku, u XVIII i XIX veku veoma je intenzivan prodor turskih pozajmica sa ovim sufiksom, a u XX veku se javlja i u tzv. evropskim glagolima. Sufiks -ira- u naš jezik ušao je u XVII veku i najveća frekvencija njegovog javljanja u srpskohrvatskom jeziku karakteristična je za XX vek, naročito za savremenu jezičku situaciju. U različitim varijantama ovaj sufiks postoji i u makedonskom, bugarskom, ruskom, skandinavskim jezicima, latinskom, francuskom i nemačkom, što mu daje izuzetnu vitalnost i omogućava njegovu visoku frekvenciju u rečima internacionalnog karaktera (Jocić 1970, 121-122).

Skok napominje da je i Vuk tolerisao sufiks -irati i prenosi stav Maretića, čija se gramatika drži Vukovog jezika, da -isati nije „nimalo srpskije“ od -irati, ali napominje da Maretić nije vodio računa o tome da sufiks -isati nije moguće zameniti sa -irati u već navedenim slučajevima kao što su turcizmi, čisti grecizmi i sl. (Skok 1955-56, 41). Skok takođe navodi da je odavno kod „čistilaca jezika“ postojala tendencija da se strani glagolski sufiksi -isati i -irati zamene domaćim denominalnim glagolskim sufiksom -ovati, koji potiče iz praslovenskog doba, a bio je na svakom stepenu našeg jezičkog razvitka živ i plodan, pa se pojavila težnja da mu se ista funkcija osigura i za aktuelni jezički razvitak. Prema Skoku, postoji izvesna razlika između ovog denominalnog sufiksa i stranih sufiksa -isati i -irati u pogledu denominalnosti, jer su druga dva retko kada čisti denominali. To je slučaj samo onda kad od stranih glagola, koje oni kod nas zamenjuju, već postoje imenice koje se poklapaju sa korenom glagola (npr. kod respektirati već postoji imenica respekt). U velikoj većini slučajeva osnovne imenice glagola na -isati i -irati imaju apstraktne strane sufikse (npr. korupcija uz korumpirati) i u tim bi se slučajevima moglo govoriti samo o logičkoj denominalnosti u izvođenju na -isati i -irati, nikako o gramatičkoj gde se traži istovetnost imenice i glagolske osnove. Međutim, u semantičkom pogledu, sufiks -ovati se u potpunosti poklapa sa sufiksima -isati i -irati i označava da je imenička osnova dobila značenje glagola, odnosno glagolske radnje. Zbog toga je i danas lako stvarati glagole na -ovati od imenica, bilo konkretnog bilo apstraktnog značenja. Na osnovu toga Skok (Skok 1955-56, 42) zaključuje da se ne može izvesti nikakvo određeno pravilo kada se mora upotrebljavati -ovati, kada -irati, a kada -isati.

Što se situacije u hrvatskom standardu tiče, Hrvatska gramatika (Barić i dr. 1997) naglašava da se sufiksom -ova- u hrvatskom jeziku tvore glagoli od imenica, kao i da se sufiksom -ira- tvore glagoli uglavnom od imenica 
stranog porekla ili od stranih glagola: adresirati, frazirati, lakirati, modelirati, demonstrirati, filozofirati.

Jernej, navodeći dosta starih primera iz Rječnika Jugoslovenske akademije znanosti i umetnosti (Rječnika hrvatskoga ili srpskoga jezika-RJAZU), ističe da se prilikom tvorbe novih glagola sufiksom -ira- javljaju mnoge alternacije (k>c: muzicirati, gimnasticirati, evocirati, locirati, provocirati) i retko dolazi posle vokala (praktično samo u kreirati, evoluirati, fluktuira$t i$, situirati, perfektuirati i dr). Najveći deo glagola na -irati čine izvedenice od imenica stranog porekla. Motivacioni odnosi su neprozirni u tim primerima, te razvrstavanje po semantičkim grupama nije relevantno (Jernej 1959, 31-40).

Milivoj Pavlović u jednom svom kratkom radu s kraja prve polovine 2o. veka iznosi zapažanje da je završetak -irati dobio vrlo široku primenu, naročito kod glagola stranog porekla ili onih koji su izvedeni od stranih reči, obično nemačkih ili primljenih u nemačkoj formi (npr. kreirati, marširati, revidirati). Smatrao je da je borba ovog završetka sa -ivati i -isati interesantna i da bi se tu mogao donekle ustanoviti geografski odnos, a do izvesne mere i jedna vrsta reparticije (Pavlović 1940, 82).

Skok na osnovu brojnih primera postavlja pravilo da se na istoku jezičke teritorije pokazuje tendencija vezivanja sufiksa -isati za latinske, ređe za grčke, a još ređe za francuske internacionalne reči. Svi ti primeri na zapadu jezičke teritorije imaju nastavak -irati, a jedino u turcizmima nije moguće na zapadu -isati zameniti sa -irati. On primećuje da se na osnovu RistićKangrginog rečnika dobija utisak da je sufiks -irati prodro i u Srbiju i da tu nadmašuje oba druga sufiksa, kao i da beogradski jezički osećaj nikako ne pušta beskrajno generalizovanje sufiksa -isati na štetu sufiksa -irati (Skok 1955-56, 39-40).

O istoj problematici govori Mihailo Stevanović u svom radu Neke leksičko-stilske razlike, a ne jezičke varijante iz 1964-65. godine, gde se bavi problemom nastavaka prilikom izvođenja glagola od osnova stranog porekla. Iznosi da su među izvedenim rečima nejednako građenim kod Hrvata i Srba najčešće navođeni glagoli stranog porekla s nastavcima -ovati, -irati i -isati, tipa: operirati-operisati i rehabilitirati-rehabilitova$t i$, kao i to da je:

s pravom isticano [...] da su glagoli u prvom navedenom obliku primljeni kod nas uglavnom iz nemačkog jezika, i s nastavkom za osnovu -ir, pa im je dodat samo domaći završetak -ati (operirati, rehabilitirati) - pretežno kod Hrvata, a u drugom su obliku prim- 
ljeni s nastavkom za osnovu -is, koji je grčkog porekla, i na koji je dalje dodat isti završni deo -ati (operisati), ili je uzet samo opšti deo, na koji se dodavao ne samo isti završni nastavak već i domaći nastavak za osnovu -ov (rehabilitovati) - pretežno kod Srba. Ali ni ovde nemamo prvo samo kod Hrvata, a drugo i treće samo kod Srba, već se, kako je dobro poznato, veliki broj glagola na -irati, kao što su: gravitirati, deklinirati, finansirati, oponirati i dr. i kod Srba upotrebljava isključivo u obliku s ovim nastavkom; drugi se upotrebljavaju naporedo, s nastavkom -irati i nastavkom -isati, ili s nastavkom -irati i domaćim nastavkom -ovati (Stevanović 1964-65, 202-203).

Mirjana Jocić se u svom istraživanju iz 197o. godine bavila glagolima sa sufiksima -isa-, -ira-, -ova- u savremenom srpskohrvatskom jeziku, sa ciljem da se na bazi postojećih rečničkih izvora savremenog srpskohrvatskog jezika prezentuje što potpuniji materijal u vezi sa ovim sufiksima i na osnovu toga razmotri i prokomentariše frekventnost, kao i neki kulturno-istorijski, etimološki, semantički i morfofonološki elementi javljanja ovih sufiksa u našem jeziku. Iz prezentovanog materijala vidi se da, mada je evidentan hronološki prioritet sufiksa -ova-, odnosno -isa-, ipak postoji izrazita predominacija oblika glagola sa sufiksom -ira- i -izira- nad oblicima sa sufiksom -ova- i -isa-. Kod glagola starijeg porekla retka je paralelna upotreba sufiksa, dok je kod glagola novijeg porekla znatno češća, naročito sufiksa -izira : -izova. Uočljiva je ograničenost reči turskog porekla na jedan sufiks - gotovo uvek -isa-, i domaćih reči gotovo uvek na -ova-. Sufiks -ovadobijaju i mnogi glagoli stranog porekla: driblovati, linčovati, organizova$t i$, apelovati, letovati. S druge strane, sufiks -isa- javlja se u rečima koje nisu grčkog i turskog porekla: definisati, legitimisati, hohštaplerisati; -ira- se nalazi i u sloju internacionalne leksike poreklom iz grčkog, i, sasvim retko, turskog.

Ne bi se, prema tome, mogla izvršiti striktna reparticija sufiksa prema etimološkom kriteriju prema kojoj bi sufiksi -isa- i -irabili ograničeni samo na reči stranog porekla, a -ova- na reči domaćeg porekla, odnosno prema kojoj bi sufiks -isa- bio ograničen samo na reči grčkog i turskog porekla, a sufiks -ira- na reči latinskog, nemačkog, francuskog, engleskog i italijanskog porekla. (Jocić 1970, 168) 
Na samom kraju autorka iznosi zaključak da je ekspanzija sufiksa -irau savremenom srpskohrvatskom jeziku neosporna; sufiks -isa- u mnogo manjoj meri ima, takođe, tendenciju širenja, ali u obrazovanjima novijeg tipa koja ne spadaju u književni jezik. Mada je po broju oblika zastupljenih u materijalu sufiks -ova- znatno frekventniji od sufiksa -isa-, ovaj sufiks nije tako karakterističan za nova građenja, a sve to treba posmatrati kao ujednačavanje na balkanskoj osnovi (sufiks -isa-) i kao vid izvesne internacionalne jezičke integracije (sufiks -ira-). Dalje, autorka zapaža da je jezik tadašnjih književnih dela, publicistike, radija, televizije, govorni i šatrovački jezik, značajan izvor novih glagola sa sufiksima -isa- i -ira-, tim pre što se upotreba ova dva sufiksa (pre svega -isa-) sve više koristi za postizanje naročitosti izraza. Na osnovu materijala se može potvrditi postojanje relevantne različitosti u upotrebi tri razmatrana sufiksa na istoku i na zapadu naše jezičke teritorije.

Noviji materijal sa sufiksima -ira-, -isa- i -ova- pokazuje tendenciju, gde god ne deluje neki od pomenutih ograničavajućih faktora, naporednog javljanja dva odnosno tri sufiksa kod glagola iste derivacione osnove. Visoka frekvencija upotrebe sifiksa -ira- i -isa-, i njihova upotreba za obrazovanje glagola od domaćih osnova, svedoči o odomaćivanju, može se reći potpunom usvajanju ovih sufiksa u srpskohrvatskom jeziku. Tendencija 'prevođenja' sufiksa -ira- i -isa- sufiksom -ova- skoro da više i ne postoji. Neophodno da se prisustvo stranih reči sa ovim sufiksima, i sami ti sufiksi, tretiraju kao vid bogaćenja srpskohrvatskog jezika, a ne kao 'strano telo' kojega se treba dosledno oslobađati (Jocić 1970, 168-174).

Spiskovi glagola deriviranih sufiksom -ova- koje čitamo u radovima Ristić-Cvijić (1970, 134-144) beleže i zastarele oblike, koji bi se za današnji jezik morali drugačije podeliti (diktovati, riskovati), kao i varijante koje su samo hrvatske (emitirati, kondenzirati, suspendirati i sl.). Takvih najviše ima internacionalnih latinizama, potom slede reči iz francuskog (angažovati, rezonovati), stariji germanizmi (pelcovati, dihtovati, štelovati), kao i sve veći upliv anglicizama počev od 20. veka (startovati, driblovati, piknikovati, flertovati).

B. Tošovićprenosi stavSlavka Vukomanovića, iznet u radu Srpskohrvatski standardni jezik, njegove varijante i ime iz 1987. godine, u kom je pratio izlaganja političara iz Srbije i Hrvatske, da se razlike između srpske i hrvatske varijante srpskohrvatskog jezika svode na svega nekoliko stavki, od kojih je jedna i upotreba sufiksa -ira- koji je dosta produktivan (Tošović-Wonish 2011, 624). Takođe, Tošović ukratko iznosi i mišljenje Lalića da: 
se leksičke razlike između dviju varijanti ne tiču nigdje sistema građenja riječi ili nekog drugog jezičkog principa, s tim što izuzetak čine dva slučaja: 1. glagoli sa sufiksima -isa, -ova i -ira (Hrvati češće upotrebljavaju glagole sa -ira, dok Srbi koriste sva tri) [...] (Tošović-Wonish 2011, 699).

Isti autor u okviru istog zbornika u svom radu Dvjesta godina srpskih pogleda na jezik Srba, Hrvata, Bošnjaka/Muslimana i Crnogoraca iz 2011. daje sumaran prikaz svih dotadašnjih istraživanja i pogleda i konstatuje da se na tvorbenom planu ukazuje na nejednaku zastupljenost glagolskih sufiksa -isa- i -ira-. Slaže se sa konstatacijom Pavla Ivića da „između dve varijante nema glasovnih i gramatičkih suprotnosti, slobodnih od leksičkih ograničenja, sa jednim izuzetkom - dvostrukim izgovorom u obliku ekavice i ijekavice“ (Tošović-Wonish 2011, 740).

\section{Korpus i hipoteze istraživanja}

Kao što je u uvodnom delu već navedeno, korpus za ovo istraživanje čine tekstovi iz Nedeljnih informativnih novina, tačnije četiri broja ovog nedeljnika. U obzir su došli svi objavljeni tekstovi, među kojima su u najvećem procentu zastupljeni tekstovi srpskih autora. Postoji i nekoliko tekstova hrvatskih autora, koji su za ovo istraživanje značajni jer predstavljaju ilustraciju sličnosti i razlika među standardima dvaju jezika. Iz tekstova su ekscerpirani glagoli u svim ličnim glagolskim oblicima, infinitivu, glagolski prilozi, kao i glagolski pridevi u sklopu složenih glagolskih oblika, a u radu su ti glagoli prikazani u svom osnovnom obliku (infinitivu).

$\mathrm{Na}$ osnovu uvida u relevantnu literaturu pretpostavlja se da se ne može povući jasna granica između srpskog i hrvatskog standarda kada je u pitanju derivacija glagola sa osnovama stranog porekla i posmatranim sufiksima, pa će se javiti glagoli koji se deriviraju uz pomoć istog sufiksa (-ira-) u oba jezika. Takođe, budući da se radi o tekstovima čiji su autori pretežno izvorni govornici srpskog jezika, očekuje se da će prevagnuti upotreba domaćeg sufiksa -ova- i odomaćenog -isa- nad sufiksom -ira-, bar u onim primerima koji ilustruju razlike među jezicima. S druge strane, s obzirom na to da je u dosadašnjim istraživanjima primećena ekspanzija sufiksa -ira- u srpskom jeziku, očekivani su i takvi primeri koji će odslikati odstupanje od norme standardnog srpskog jezika. 


\section{Analiza i rezultati istraživanja}

Pošto smo predstavili teorijska utemeljenja ovog rada i dali preglede ranijih istraživanja koja su u neposrednoj vezi sa našim ispitivanim sufiksima, opisali korpus i izneli osnovne hipoteze, prelazimo na analizu naše ekscerpirane građe. Ukupno je izdvojen 241 glagol deriviran sufiksima -isa-, -ira- i -ova-. Fond tih glagola predstavićemo u vidu tabele:

\begin{tabular}{|c|c|c|c|}
\hline - & -ova- & -isa- & -ira- \\
\hline grč. & $\begin{array}{l}\text { demokratizovati, ho- } \\
\text { mogenizovati, kan- } \\
\text { onizovati, kritikovati, } \\
\text { tematizovati }\end{array}$ & $\begin{array}{l}\text { fotografisati, katego- } \\
\text { risati, koreografisa- } \\
\text { ti, okarakterisati, par- } \\
\text { anoisati }\end{array}$ & $\begin{array}{l}\text { apostrofirati, orkestrirati, para- } \\
\text { frazirati }\end{array}$ \\
\hline lat. & $\begin{array}{l}\text { apelovati, asimilova- } \\
\text { ti, deponovati, depro- } \\
\text { vincijalozovati, desta- } \\
\text { bilizovati, diskutovati, } \\
\text { diskvalifikovati, edu- } \\
\text { kovati, emitovati, fab- } \\
\text { rikovati, falsifikovati, } \\
\text { identifikovati, ilustro- } \\
\text { vati, institucionalizo- } \\
\text { vati, iskomplikovati, } \\
\text { kandidovati, kombi- } \\
\text { novati, komplikova- } \\
\text { ti, kompromitovati, } \\
\text { konkretizovati, kon- } \\
\text { sultovati, korigovati, } \\
\text { kvalifikovati, okvali- } \\
\text { fikovati, praktikovati, } \\
\text { pretendovati, prezen- } \\
\text { tovati, profesionalizo- } \\
\text { vati, radikalizovati, } \\
\text { reflektovati, relativ- } \\
\text { izovati, resocijalizo- } \\
\text { vati, suspendovati, tri- } \\
\text { jumfovati, unifikovati, } \\
\text { zakomplikovati }\end{array}$ & $\begin{array}{l}\text { afirmisati, artikulisa- } \\
\text { ti, deflorisati, deter- } \\
\text { minisati, dezinfor- } \\
\text { misati, eliminisati, } \\
\text { formulisati, funkcion- } \\
\text { isati, generisati, igno- } \\
\text { risati, informisati, in- } \\
\text { spirisati, integrisati, } \\
\text { intervenisati, izmanip- } \\
\text { ulisati, kanalisati, ko- } \\
\text { mentarisati, koncen- } \\
\text { trisati, konkurisati, } \\
\text { konstituisati, kon- } \\
\text { struisati, manipulisa- } \\
\text { ti, profunkcionisati, } \\
\text { prokomentarisati, pro- } \\
\text { movisati, reformisati, } \\
\text { regulisati, rekonstrui- } \\
\text { sati, spekulisati, stim- } \\
\text { ulisati, subvencionisa- } \\
\text { ti, sugerisati, tolerisati, } \\
\text { transformisati }\end{array}$ & $\begin{array}{l}\text { abolirati, aktivirati, animira- } \\
\text { ti, anulirati, asocirati, demoli- } \\
\text { rati, demonstrirati, diktira- } \\
\text { ti, dimenzionirati, doktorirati, } \\
\text { dominirati, donirati, egzistira- } \\
\text { ti, eksplodirati, emigrirati, fik- } \\
\text { sirati, fokusirati, generirati, il- } \\
\text { ustrirati, inicirati, inscenirati, } \\
\text { insinuirati, insistirati, intenzi- } \\
\text { virati, interpretirati, investirati, } \\
\text { iziritirati, kastrirati, katapulti- } \\
\text { rati, kolaborirati, komunici- } \\
\text { rati, konotirati, konzumirati, } \\
\text { kooptirati, kreirati, kulmini- } \\
\text { rati, likvidirati, locirati, mag- } \\
\text { istrirati, navigirati, negirati, } \\
\text { nervirati, preferirati, prejudi- } \\
\text { cirati, procesuirati, prolongi- } \\
\text { rati, propagirati, redistribui- } \\
\text { rati, relaksirati, restaurirati, } \\
\text { restrukturirati, sanirati, signal- } \\
\text { izirati, stagnirati, strukturirati, } \\
\text { studirati, sublimirati, tangira- } \\
\text { ti, tempirati, testirati, urgirati, } \\
\text { uzurpirati, varirati }\end{array}$ \\
\hline
\end{tabular}




\begin{tabular}{|c|c|c|c|}
\hline- & -ova- & -isa- & -ira- \\
\hline fr. & $\begin{array}{l}\text { angažovati, atakova- } \\
\text { ti, bombardovati, de- } \\
\text { batovati, demantovati, } \\
\text { diskreditovati, doka- } \\
\text { pitalizovati, formal- } \\
\text { izovati, garantovati, } \\
\text { interesovati, izolova- } \\
\text { ti, konstatovati, legal- } \\
\text { izovati, mobilizovati, } \\
\text { modernizovati, nor- } \\
\text { malizovati, organizo- } \\
\text { vati, prodefilovati, pro- } \\
\text { testvovati, realizovati, } \\
\text { regrutovati, rezono- } \\
\text { vati, rizikovati, stabi- } \\
\text { lizovati }\end{array}$ & $\begin{array}{l}\text { demoralisati, iskris- } \\
\text { talisati, karakterisati, } \\
\text { kontrolisati, motivisa- } \\
\text { ti, neutralisati, pro- } \\
\text { filisati }\end{array}$ & $\begin{array}{l}\text { analizirati, ažurirati, balansi- } \\
\text { rati, bazirati, dezavuirati, ese- } \\
\text { jizirati, etablirati, finansirati, } \\
\text { kopirati, maltretirati, maski- } \\
\text { rati, minirati, montirati, plan- } \\
\text { irati, plasirati, precizirati, ran- } \\
\text { girati, realizirati, reprizirati, } \\
\text { revoltirati, servirati, servisira- } \\
\text { ti, simulirati, šokirati, trenirati, } \\
\text { tretirati, umarširati, volontira- } \\
\text { ti, zamaskirati }\end{array}$ \\
\hline nem. & $\begin{array}{l}\text { lumpovati, prošverco- } \\
\text { vati, reagovati, šver- } \\
\text { covati }\end{array}$ & definisati, referisati & $\begin{array}{l}\text { blokirati, diplomirati, distanci- } \\
\text { rati, dozirati, formirati, gusti- } \\
\text { rati, isprovocirati, kompletirati, } \\
\text { lavirati, odblokirati, okupirati, } \\
\text { pozicionirati, profitirati, provo- } \\
\text { cirati, reaktivirati, renovirati, } \\
\text { rezultirati }\end{array}$ \\
\hline engl. & $\begin{array}{l}\text { detektovati, dopingo- } \\
\text { vati, monopolizovati, } \\
\text { startovati }\end{array}$ & intervjuisati & $\begin{array}{l}\text { aplicirati, implementirati, lim- } \\
\text { itirati, lobirati, targetirati }\end{array}$ \\
\hline ital. & & & intrigirati, skicirati \\
\hline
\end{tabular}

U tabeli je pored ekscerpiranih glagola naznačeno i poreklo glagolske osnove, tj. jezik iz kog je ona potekla ili preuzeta, naravno sa podrazumevanim morfofonološkim adaptacijama u srpskom jeziku. Iz tabele možemo da iščitamo sledeće relevantne podatke:

Strani sufiks -ira- pokazuje najveću distributivnost kad su osnove stranog porekla u pitanju - 119 evidentiranih glagola. Najčešće dolazi na osnove latinskog porekla - 63, što je u procentima 52,94\%, potom na osnove poreklom iz francuskog - $29(24,37 \%)$ i nemačkog - 17 (14,39\%), dok su malobrojnije osnove iz engleskog - $5(4,2 \%)$, grčkog - $3(2,52 \%)$ i italijanskog porekla - 2 (1,68\%). U analiziranoj građi pronašli smo zanimljive primere glagola kod kojih, prema pravilima navedenim kod M. Šipke i I. Klajna, umesto ovog sufiksa fungiraju druga dva (-isa- i -ova-) ili je dozvoljena naporedna upotreba. Navedeni glagoli se u analiziranoj građi gotovo dosledno javljaju sa sufiksom -ira-, kao na primer analizirati : analizovati, dezavuirati : dezavuisati, kolaborirati : kolaborisati, navigirati : navigati, signalizirati : signalizovati, sublimirati : sublimisati. Kao što se vidi iz pregleda literature, upravo 
su svi ovi primeri sa -ira- karakteristični prevashodno za hrvatski standard, te se kao hrvatski uticaj mogu sporadično javiti i u srpskom jeziku, iako nisu potvrđeni u literaturi (Veliki rečnik stranih reči i izraza).

Opšteslovenski sufiks -ova- nalazi se u medijalnoj poziciji u odnosu na sufikse -ira- i -isa- po broju stranih glagolskih osnova u kojima je zapažen. Registrovan je u 73 glagola. Najfrekventniji je u glagolima čije su glagolske osnove latinskog - 36 (49,32\%) i francuskog porekla - 24 (32,88\%). U obrađenoj građi prisutan je u nešto manjem broju kod glagolskih osnova grčkog $-5(6,85 \%)$, nemačkog - 4 (5,48\%) i engleskog porekla - $4(5,48 \%)$.

Kao što teorija ističe, a praksa pokazuje, odomaćeni sufiks -isa- prisutan je u glagolskim osnovama stranog porekla, mada, kako naše istraživanje pokazuje, u odnosu na druga dva sufiksa evidentiran je najmanji broj takvih glagola - svega 49. U skladu s očekivanjima, kao i kod prethodna dva sufiksa, i ovaj sufiks najfrekventniji je kod glagolskih osnova latinskog porekla, i to u 34 primera $(69,39 \%)$. Prisutan je i kod glagolskih osnova grčkog - 5 (10,2\%), francuskog - 7 (14,29\%), nemačkog - 2 (4,08\%) i engleskog porekla - 1 (2,04\%), ali, kao što se vidi iz priloženog, sasvim sporadično.

Dakle, nakon što smo i kvantitativno i analitički prikazali građu, zaključujemo da teorija i jezička praksa umnogome korespondiraju. Potvrdili smo da su sufiksi koji su i bili predmet našeg istraživanja prisutni u glagolima čije su osnove stranog porekla. Uočljivo je, takođe, razgraničenje distribucije sufiksa kod pojedinih glagola u srpskom i u hrvatskom jeziku. Još jedna potvrda u prilog ovome zabeležena je u sledećim primerima iz našeg korpusa (primeri glagola sa -ira- registrovani su u tekstovima hrvatskih, a sa -isa- i -ova- u tekstovima srpskih autora):

Žalosni slučaj Tihomira s početka ove priče dosta dobro to ilustrira. (NIN, 14. 7, str. 27, autor: Ante Tomić) - (...) izložba Putevi revolucije - Memorijalni turizam u Jugoslaviji, od 1. jula do 31. avgusta u Muzeju istorije Jugoslavije (koncept: Lana Lovrenčić, Milan Rakita), ilustrovaće kako su spomenici postali deo turističke ponude. (NIN, 21. 7, str. 52, autor: M. V.)

Želi da „generira političku stabilnost, pravnu sigurnost, gospodarski rast, te društvenu solidarnost i uključenost“. (NIN, 21. 7, str. 6, autor: Andrej Plenković). - Dakle, Kamaraš je sirovine plaćao po cenama višim od onih po kojima su kupovale konkurentske čeličane, što je generisalo gubitke u Želežari, tvrdi Milićević... (NIN, 21. 7, str. 31, autor: Pertica Đaković) 
Malo je poznato da je Mostar u poslijeratnoj obnovi unakažen gotovo jednako kao u ratu, tamo su svi projekti koji se realiziraju pod krinkom progresa. (NIN, 21. 7, str. 19, autor: Marko Tomaš) - Da li je Srbija u stanju da taj novac realizuje? (NIN, 21. 7, str. 11, autor: Nikola Tomić)

U istom broju nedeljnika uočena je paralelna distribucija sufiksa -isa-, -ira- i -ova- u istim glagolskim osnovama stranog porekla, što je samo potvrda kontinuiteta u tvorbi ovih glagola, o čemu je pisano u prikazanim radovima iz ranijeg perioda. Za razliku od ovog fleksibilnog normativističkog stava u pogledu tvorbe glagola stranog porekla s posmatranim sufiksima u srpskom standardu, na osnovu onoga što nam je bilo dostupno u literaturi o hrvatskom standardu, možemo zaključiti da je tvorba ovih glagola u okvirima stabilne paradigme.

\section{Zaključak}

Ispitujući glagole čije su generativne baze uglavnom stranog porekla i distribuciju sufiksa -ova-, -isa- ili -ira-, cilj nam je bio da se proveri usklađenost zatečenog stanja sa srpskim standardom, odnosno da li se derivacija sprovodi u skladu s utvrđenim normama srpskog književnog jezika, postoji li neki uticaj hrvatskog, te da li postoji jasna granica između ova dva standarda. U skladu s ciljem, prvo smo predočile propisane norme savremenog srpskog i hrvatskog jezika, a potom ih uporedile sa stanjem dobijenim na temelju rezultata analize i sa ranijim zaključcima o ovoj temi. Korpus za analizu sastojao se od informativnih tekstova iz srpskog nedeljnika. Nakon istraživanja sprovedenog na 241 ekscerpiranom glagolu, potvrđena su 73 glagola izvedena sufiksom -ova-, 49 glagola primeri su izvedeni sufiksom -isa- i 119 glagola izvedeno je sufiksom -ira-. Sufiksi -isa- i -ova- tipični su domaći (odnosno jedan, prvi, odomaćen) sufiksi, dok je sufiks -ira- izdvojen kao strani. Potvrđeno je u našem korpusu da su najbrojniji oni glagoli stranih baza izvedeni sufiksom -ira-, što je u suprotnosti s očekivanjima, budući da srpska derivatologija smatra sufiks -ova- najproduktivnijim. Vidljiv je uticaj hrvatskog standarda u srpskom književnom jeziku, premda ne možemo biti u potpunosti sigurni u smer tih odnosa, budući da je reč o dva genetski ista jezika. Dobijeni rezultati se $u$ velikoj meri slažu sa ranijim istraživanjima - $u$ hrvatskom standardu, koji je prilično hermetičan, i danas je zastupljena uglavnom upotreba sufiksa -ira-, a u srpskom standardu je sve jača tendencija širenja ovog sufiksa i ne postoji izražena potreba za prevođenjem ovog sufiksa sufiksom -ova- ili -isa-. 


\section{Izvori}

Клајн, Иван и Милан Шипка. 2006. Велики речник страних речи и израза. Нови Сад: Прометеј.

Недељне информативне новине (НИН), 2016. бр. 3420 (14.7.2016), 3421 (21.7.2016), 3426 (25.8.2016.), 3427 (01.9.2016). ур. Милан Ћулибрк. Београд: Рингиер Ахел Спрингер.

\section{Literatura}

Barić, Eugenija i dr. 1997. Hrvatska gramatika. Zagreb: Školska knjiga.

Jernej, Josip. 1959. »Glagoli na -irati u XVII i XVIII stoljeću«. Filologija 2: 31 $-40$.

Јоцић, Мирјана. 1970. »Глаголи са суфиксима -иса, -ира, -ова у савременом српскохрватском књижевном језику«. Прилози проучавању језика 5: $121-175$.

Клајн, Иван. 2003. Творба речи у савременом српском језику. Други део - суфиксација и конверзија. Београд: Завод за уџбенике и наставна средства, Институт за српски језик САНУ, Матица српска.

Павловић, Миливој. 1940. »Ширење инфинитива типа -ирати«. Наш језик VII (2-3), с.c.: 81-82.

Ristić-Cvijić, Olga. 1970. »Odnos osnove i nastavka -ovati, -isati, -irati glagola stranog porekla«. Naš jezik XVIII, n.s.: 131-161.

Skok, Petar. 1955-1956. »O sufiksima -isati, -irati i -ovati«. Jezik IV (2): 36-43.

Skok, Petar. 1971-1974. Etimologijski rječnik hrvatskoga ili srpskoga jezika. Priredio za tisak Valentin Putanec. I-IV, Zagreb.

Станојчић, Живојин и Љубомир Поповић. 2002. Граматика српског језика, Шесто прерађено издање. Београд: Завод за уџбенике и наставна средства, 160.

Стевановић, Михаило. 1964-1965. »Неке лексичко-стилске разлике, а не језичке варијанте«. Наш језик XIV (4-5), н.с.: 195-226.

Tošović, Branko i Arno Wonish, ur. 2011. Srpski pogledi na odnose između srpskog, hrvatskog i bošnjačkog jezika I/3. Graz: Institut fur Slawistik der Karl-Franzens-Universitat Graz - Beograd: Beogradska knjiga. 


\section{Avtorji / Authors}

Alenka Čuš je leta 2011 diplomirala na Fakulteti za humanistične študije v Kopru iz slovenskega šolstva in knjižnic v Argentini. Od leta 2013 kot doktorska kandidatka na isti fakulteti neodvisno raziskuje kanadsko-slovensko izseljensko skupnost v Ontariu z notranjim statusom raziskovalca in je odgovorna urednica osrednje revije za kanadske Slovence Glasilo ter članica Vseslovenskega kulturnega odbora (VSKO).

Alenka Čuš graduated from Slovene Studies at the Faculty of Humanities in Koper in 2011 with a thesis on the Slovenian school system and libraries in Argentina. As a PhD Candidate at the same Faculty she has been independently researching the Slovene Canadian immigrant community in Ontario with the intrafaculty status of researcher. Since 2013 she is Chief Editor of Glasilo magazine, the main publication of Slovenes in Canada and thereby also a de facto member of the Board of Directors of the All Slovenian Cultural Committee (ASCC).

Barbara Kopač je diplomirala iz mednarodnih odnosov in magistrirala iz diplomacije na Fakulteti za družbene vede v Ljubljani. Sočasno z magistrskim študijem se je vpisala na Filozofsko fakulteto, smer Slovenistika Kulture vzhodne Azije. Jezikoma se je kmalu pridružila švedščina, katere znanje je v letu 2015 izpopolnjevala na Švedskem, kjer je opravljala tudi raziskovalno delo. V letu 2016 je poglabljala svojo raziskavo in znanje japonskega jezika na Univerzi v Tsukubi. Septembra 2016 je pridobila naziv di- 
plomirane kulturologinje Vzhodne Azije, oktobra pa začela z doktorskim študijem Humanistika in družboslovje na Filozofski fakulteti, kjer interdisciplinarno povezuje področji slovanskih jezikov in diplomacije.

Barbara Kopač graduated in International Relations and earned a Master's degree in Diplomacy from the Faculty of Social Sciences in Ljubljana. During her Master's studies, she enrolled in the Faculty of Arts as a student of Slovene language and East Asian Studies. To her knowledge of two languages she added Swedish, which she upgraded, studying in Sweden in 2015, where she also conducted research. In 2016, she deepened her research and knowledge while studying Japanese at the University of Tsukuba. In September 2016, she graduated in East Asian Studies and in October 2016, she started her $\mathrm{PhD}$ in Humanities and Social Sciences at the Faculty of Arts, combining Slavic languages and diplomacy in interdisciplinary way.

Maja Smotlak je doktorirala leta 2014 na Oddelku za slovenistiko Fakultete za humanistične študije Univerze na Primorskem. Trenutno je zaposlena kot raziskovalka na Znanstveno-raziskovalnem središču Koper. Redno piše literarne kritike za radijsko oddajo Kulturni dogodki Radia Trst A in občasno za revijo Mladika.

Maja Smotlak received her $\mathrm{PhD}$ in 2014 at the Department of Slovene Studies, Faculty of Humanities, University of Primorska. Currently she is working as a researcher at the Science and Research Centre Koper. She regularly writes literary critiques for the radio show Kulturni dogodki at Radio Trst A and occasionally for the magazine Mladika.

Rok Andres je doktorski študent študijskega programa Humanistika na Fakulteti za podiplomski študij Univerze v Novi Gorici. Leta 2014 je diplomiral na oddelku za dramaturgijo AGRFT. Kot asistent in dramaturg je deloval pri uprizoritvah v slovenskih gledaliških hišah. Redno piše strokovna in znanstvena besedila za gledališke liste in druge publikacije. Zaposlen je kot asistent, mladi raziskovalec na Univerzi v Novi Gorici, kjer se posveča dramatiki in gledališču.

Rok Andres is a $\mathrm{PhD}$ candidate at the Humanities program at the Graduate School of the University of Nova Gorica. In 2014, he graduated from the Department of Dramaturgy at the Academy for Theatre, Radio, Film and Television in Ljubljana. As an assistant and dramaturge he participated in theatre productions in various Slovenian theatre houses. He is an author of expert and technical articles in various theatrical and other publicati- 
ons. Currently, he is employed as a young researcher and teaching assistant at the University of Nova Gorica which is dedicated to the fields of drama and theatre.

Megi Rožič je na Fakulteti za podiplomski študij Univerze v Novi Gorici, smer Humanistika, doktorirala $\mathrm{z}$ intedisciplinarno doktorsko disertacijo $\mathrm{z}$ naslovom: Avtobiografska izkušnja migracije $\mathrm{v}$ delih literarnih ustvarjalk slovenskega literarnega polisistema. Od leta 2012 do 2016 je bila mlada raziskovalka na Raziskovalnem centru za humanistiko Univerze v Novi Gorici in asistentka za področje književnosti na Fakulteti za humanistiko iste univerze. S študijskim letom 2016/17 je asistentka z doktoratom za področje slovenske književnosti na Univerzi v Novi Gorici. Njena raziskovalna področja in zanimanja segajo na polja feministične literarne vede in migracijskih študij. S teh področij je doslej pripravila več znanstvenih in strokovnih člankov ter pisnih prispevkov, sodelovala je na okroglih mizah, konferen$\mathrm{cah}, \mathrm{v}$ radijskih oddajah in posvetih.

Megi Rožič has completed an interdisciplinary $\mathrm{PhD}$ in Humanities at the Graduate School of the University of Nova Gorica, entitled: The Autobiographical Experience of Migration in the Literary Works of Women Writers of the Slovenian Literary Polysystem. From 2012 to 2016 she worked as a junior researcher at the Research Center for Humanities of the University of Nova Gorica and as an assistant lecturer for the field of literature at the Faculty of Humanities at the same university. During the academic year 2016/17 she has been an assistant with a $\mathrm{PhD}$ in the field of Slovenian Literature at the University of Nova Gorica. Her areas of research are feminist literary studies and migration studies. Within these areas she has so far produced several technical and expert articles and other written contributions and participated in round-table discussions, conferences, radio shows and conferences.

Mateja Eniko je na Filozofski fakulteti Univerze v Ljubljani študirala slovenistiko in primerjalno književnost. Diplomirala je leta $2010 \mathrm{z}$ diplomsko nalogo Humor in ironija v poeziji Milana Jesiha (mentorja dr. Irena Novak Popov in dr. Matevž Kos). Po diplomi je delala kot asistentka za slovenski jezik na avstrijskem Koroškem. Od leta 2009 sodeluje s Centrom za slovenščino kot drugi/tuji jezik. Od leta 2014 dela na Univerzi v Novi Gorici kot mlada raziskovalka in asistentka za književnost. V okviru doktorskega študija se pod mentorstvom ddr. Irene Avsenik Nabergoj ukvarja s sodob- 
no slovensko poezijo na Fakulteti za podiplomski študij Univerze v Novi Gorici.

Mateja Eniko studied Slovenian studies and comparative literature at the Faculty of Arts in Ljubljana. She graduated in 2010 with the thesis Humour and irony in the poetry of Milan Jesih under the supervision of dr. Irena Novak Popov and dr. Matevž Kos. During the school year 2010/2011 she worked as an assistant for the Slovene language in Austrian Carinthia. Since 2009 she has been an associate of the Centre for Slovene as a Second and Foreign Language. Since 2014 she has been working at the University of Nova Gorica as a junior researcher and a teaching assistant in literature. She is a $\mathrm{PhD}$ student at the Graduate School of the University of Nova Gorica and she is researching contemporary Slovene poetry under the supervision of ddr. Irena Avsenik Nabergoj.

Jernej Kusterle, magister profesor slovenistike, doktorski študent na Podiplomski šoli ZRC SAZU, je diplomiral z delom Strukturalna poetika ulične poezije, magistriral pa $z$ delom Teorija slovenske ulične poezije in družbeni kontekst, za katerega je v letu 2016 prejel študentsko Prešernovo nagrado. Ob tem je ulično poezijo utemeljil tudi v znanstvenih člankih: Stilistika ulične poezije (Primerjalna književnost 37.1; 109124), Zgodovinski in tipološki pregled ulične poezije (Jezik in slovstvo 59.4; 97-110), Ulična poezija v interakciji z (živim) jezikom (Jezikoslovni zapiski 20.1; 93-105), Vplivi spleta na slovensko ulično poezijo (Slavistična revija 63.4; 419-430) in Afirmacija spleta v ulični poeziji (Filološke pripombe 2016 (Prvi zvezek); 222-236).

Jernej Kusterle is a master's degree professor of Slovenian studies and $\mathrm{PhD}$ student at the Postgraduate school of ZRC SAZU with a thesis entitled Structural Poetics of Street Poetry, and earned a master's degree for a thesis entitled Theory of Slovenian Street Poetry and Social Context, for which he got a Prešeren award for students (2016). In addition he has published several learned articles on street poetry: The Stylistics of Street Poetry (Primerjalna književnost 37.1; 109-124), A Historical and Typological Overview of Street Poetry (Jezik in slovstvo 59.4; 97-110), Street Poetry in Interaction with (Living) Language (Jezikoslovni zapiski 20.1; 93-105), Influences of the Internet on Slovene Street Poetry (Slavistična revija 63.4; 419-430) and Affirmation of Internet in Street Poetry (Philological studies 2016 (Issue 1); 222-236). 
Iveta Bůžková (1984) je na Fakulteti za družbene vede Karlove univerze v Pragi magistrirala s področja mednarodnih teritorialnih študij. Zaposlena je na Pravnem inštitutu Akademije znanosti Češke Republike. Trenutno na Masarykovi univerzi v Brnu piše doktorat s področja filoloških študij in se ukvarja s sodobno slovensko književnostjo.

Iveta Bůžková (1984) earned a master’s degree in the field of international territorial studies from the Faculty of Social Sciences at Karlov University in Prague. She works at the Institute of Law of the Academy of Sciences in the Czech Republic. Currently she is in a PhD pogramme in the field of philological studies at Masaryk University in Brno and also teaches modern Slovenian literature.

Weronika Woźnicka, absolwentka V roku filologii słowiańskiej z językiem słoweńskim i słowackim na Wydziale Filologicznym Uniwersytetu Śląskiego w Katowicach. Jej zainteresowania naukowe skupiają się wokół współczesnej literatury słoweńskiej, głównie prozy. Interesuje się również XX-wieczną historią Słowenii oraz jej kulturą. Z języka słoweńskiego przetłumaczyła 3 artykuły naukowe (Mirana Hladnika, Andreja Šurli i Tonego Smoleja). W roku 2015 otrzymała nagrodę za przekład fragmentu utworu Sonji Porle Barva sladke čokolade w konkursie „PAMIĘĆNIK. Motyw pamięci i wspomnień w literaturze", organizowanym przez Koło Naukowe Slawistów Uniwersytetu Jagiellońskiego w Krakowie.

Weronika Woźnicka graduate of Slavic Philology of the Slovene and Slovak languages in the Faculty of Philology at the University of Silesia in Katowice. Her academic interests are focused on modern Slavic literature, mostly prose. She is also interested in the 2oth century history of Slovenia and its culture. She has translated from Slovene to Polish 3 academic articles (by Miran Hladnik, Andrej Šurla and Tone Smolej). In 2015, she was awarded for translating into Polish a fragment of Sonjas Porle's Barva sladke čokolade in the "PAMIĘĆNIK: Theme of memory and recall in literature" competition, which was organized by the Slavic Science Club of Jagiellonian University in Krakow.

Janja Vollmaier Lubej je doktorica znanosti s področja literarnih ved (2013) in asistentka za predmetno področje slovenska književnost. V študijskem letu 2015/2016 je delovala kot predavateljica slovenske književnosti s statusom prostovoljke na Univerzi Ivana Franka v Lvovu. Poučevala je slovenščino na tujih univerzah, organizirala in vodila literarne večere s so- 
dobnimi slovenskimi pisatelji in pisateljicami. Udeležuje se mednarodnih znanstvenih in strokovnih konferenc, piše strokovne in znanstvene prispevke ter recenzije. Je soavtorica učbenika S slovenščino po svetu (2013), slovarja Ukrajinsko-slovenski tematski slovar (2015) in prevoda Dvanajst krogov Jurija Andruhoviča (2016).

Janja Vollmaier Lubej has a PhD degree in field of literary studies (2013) and is a teaching assistant is the field of Slovene literature. During the 2015/2016 school year she lectured as a volunteer on Slovene literature at the Ivan Franko National University of Lviv, Ukraine. She also was a teacher of Slovene language at foreign universities where she conducted and organized cultural events with contemporary Slovene writers. She attends international scientific and professional conferences, writes professional and scientific articles and reviews. She is the co-author of a textbook S slovenščino po svetu (2013), a Ukrainian-Slovene thematic dictionary Ukrajinskoslovenski tematski slovar (2015) and a translation of Yuri Andrukhovych's novel Dvanajst krogov (2016).

Константина Пунева родена в София, България през 1987 г. Тя е бакалавър по „Българска филология“ и магистър по „Литература, кино и визуална култура“ в СУ „Св. Климент Охридски“. В момента е докторант по „Руска класическа литература (XIX век)“. Темата на дисертацията ѝ е „Л. Н. Толстой като екранен сюжет: литературна и кинопоетика“. Сферите на научни интереси на Пунева са в областта на руската литература, визуалната култура, киното и социологията. Има участия в научни конференции в България, Русия и Унгария, Словения и Австрия.

Konstantina Puneva was born in Sofia, Bulgaria in 1987. She has a bachelor's degree in Bulgarian Philology and a master's degree in Literature, Cinema and Visual Culture from "St. Kliment Ohridski" Sofia University. At the moment she is a PhD student in Russian classical literature at the same university. The title of her thesis is Leo Tolstoy as a screen plot: poetics of literature and film. Her fields of interest are Russian literature, visual culture, film and sociology. She has participated in conferences in Bulgaria, Russia, Hungary, Slovenia and Austria.

Tomislav Augustinčić rođen je 1992. godine. Student je diplomskog studija etnologije i kulturne antropologije i antropologije na Filozofskom fakultetu Sveučilišta u Zagrebu. Glavni je urednik studentskog časopisa Kazivač. 
Istraživački se bavi temama antropologije društvenog sjećanja, urbane antropologije i antropologije književnosti.

Tomislav Augustinčić was born in 1992. He holds a BA in Ethnology and Cultural Anthropology and a BA in Anthropology, and is currently finishing his MA studies in these fields. He is the Chief-Editor of the student journal Kazivač. His research interests encompass anthropology of social memory, urban anthropology and literary anthropology.

Mirela Ivanić (1990) diplomirala je na Filozofskom fakultetu u Novom Sadu, na Odseku za srpski jezik i lingvistiku (septembar 2014, prosek: 9,75), gde je potom završila i master studije (septembar 2015, prosek: 10,00; master rad: Semantičko-derivaciono gnezdo lekseme zemlja) i u oktobru 2015. upisala doktorske studije (Jezik i književnost, modul: jezik). Polja interesovanja su joj tvorba reči, leksikologija i metodika nastave srpskog jezika kao maternjeg. Stipendista je Ministarstva prosvete, nauke i tehnološkog razvoja Republike Srbije i volontira kao saradnik u nastavi na Odseku za srpski jezik i lingvistiku na Filozofskom fakultetu u Novom Sadu.

Mirela Ivanić (1990) graduated from the Faculty of Philosophy in Novi Sad, Department of Serbian Language and Linguistics (September 2014, average: 9.75) where she also finished her master's studies (September 2015, average: 10.00; master's thesis title: Semantic-derivational nest of the lexeme earth) and in October 2015 enrolled in doctoral studies (Language and Literature, Language module). She is interested in derivatology, lexicology and in the methodology of teaching the Serbian language. She is a scholar of the Ministry of Education, Science and Technological Development of the Republic of Serbia and works as a volunteer at the Department of Serbian Language and Linguistics in the Faculty of Philosophy in Novi Sad.

Jelena Perišić (1991) diplomirala je na Filozofskom fakultetu u Novom Sadu, na Odseku za srpski jezik i lingvistiku (septembar 2014, prosek: 9,63), gde je potom završila i master studije (jun 2015, prosek: 10,00; master rad: Veština čitanja u nastavi srpskog jezika kao stranog) i u oktobru 2015. upisala doktorske studije (Jezik i književnost, modul: jezik). Polja interesovanja su joj savremeni srpski jezik i srpski jezik kao strani. Stipendista je Ministarstva prosvete, nauke i tehnološkog razvoja Republike Srbije i volontira kao lektor u Centru za srpski jezik kao strani na Filozofskom fakultetu u Novom Sadu. 
Jelena Perišić (1991) graduated from the Faculty of Philosophy in Novi Sad, Department of Serbian Language and Linguistics (September 2014, average: 9.63) where she also finished her master's studies (June 2015, average: 10.00; thesis title: Reading Skill in Teaching Serbian as a Foreign Language) and in October 2015 she enrolled in doctoral studies (Language and Literature, Language module). She is interested in modern Serbian language and teaching Serbian as a foreign language. She is a scholar of the Ministry of Education, Science and Technological Development of the Republic of Serbia and works as a volunteer at the Centre for Serbian as a Foreign Language at the Faculty of Philosophy in Novi Sad. 



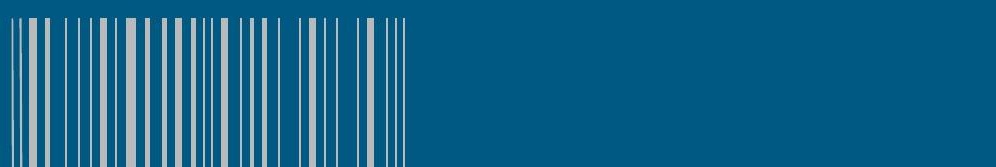

